\title{
Targeting Net Zero Energy at Fort Carson: Assessment and Recommendations
}

Prepared for the U.S. Department of Energy Federal Energy Management Program

By National Renewable Energy Laboratory Kate Anderson, Tony Markel, Mike Simpson, John Leahey, Caleb Rockenbaugh, Lars Lisell, Kari Burman, and Mark Singer

October 2011

\section{FEMPilleris




\section{NOTICE}

This report was prepared as an account of work sponsored by an agency of the United States Government. Neither the United States Government nor any agency thereof, nor any of their employees, makes any warranty, express or implied, or assumes any legal liability or responsibility for the accuracy, completeness, or usefulness of any information, apparatus, product, or process disclosed, or represents that its use would not infringe privately owned rights. Reference herein to any specific commercial product, process, or service by trade name, trademark, manufacturer, or otherwise does not necessarily constitute or imply its endorsement, recommendation, or favoring by the United States Government or any agency thereof. The views and opinions of authors expressed herein do not necessarily state or reflect those of the United States Government or any agency thereof.

Printed on paper containing at least $50 \%$ wastepaper, including $20 \%$ postconsumer waste. 


\section{Contacts}

Kate Anderson

National Renewable Energy Laboratory

Kate.Anderson@nrel.gov

303-384-7453

Tony Markel

National Renewable Energy Laboratory

Tony.Markel@,nrel.gov

303-275-4478

Vince Guthrie

Fort Carson

Vincent.Guthrie@us.army.mil

719-526-2927 


\section{Acknowledgements}

This work is sponsored by the U.S. Department of Energy (DOE) Federal Energy Management Program (FEMP). Richard Kidd is the FEMP Program Manager. Shawn Herrera administers the Technical Assistance Program. David McAndrew manages this task for FEMP.

The authors gratefully acknowledge the assistance of Vince Guthrie, Scott Clark, and Alan Davis at Fort Carson for their cooperation and assistance in support of this work. We also thank Jerry Davis, Peter Lillienthal, Robi Robichaud, Owen Roberts, Jim Bright, Otto Van Geet, and Jesse Dean for their contributions to the analysis and Tim Tetreault and Dan Olis for their review of the report. 


\section{Abbreviations and Acronyms}

$\mathrm{AC}$

AFV

AHU

ARRA

Btu

C\&D

CHP

$\mathrm{CNG}$

$\mathrm{CO}_{2}$

$\mathrm{COE}$

CSP

CSU

CV

DDC

DHW

DoD

DOE

DX

EE

EEAP

ECIP

ECM

EISA

E.O.

EPA

ESCO

ESPC

EUI

FAR

FEMP

FFRDC

FFV

FRREC

$\mathrm{ft}^{2}$

GHG

GIS

GSA

GSHP

HEV

HQ

HVAC

$\mathrm{KCF}$

$\mathrm{kVA}$

$\mathrm{kWh}$

LCOE
Alternating current

Alternative fuel vehicle

Air handling unit

American Recovery and Reinvestment Act

British thermal unit

Construction and demolition

Combined heat and power

Compressed natural gas

Carbon dioxide

Cost of energy

Concentrating solar power

Colorado Springs Utilities

Constant volume

Direct digital controls

Domestic hot water

U.S. Department of Defense

U.S. Department of Energy

Direct expansion

Energy efficiency

Energy Engineering Analysis Program

Energy Conservation Investment Program

Energy conservation measure

Energy Independence and Security Act of 2007

Executive order

U.S. Environmental Protection Agency

Energy service company

Energy savings performance contract

Energy use intensity

Federal Acquisition Regulation

Federal Energy Management Program

Federally Funded Research and Development Center

Flex fuel vehicle

Front Range Renewable Energy Consortium

square foot

Greenhouse gas

Geographic information system

U.S. General Services Administration

Ground Source Heat Pump

Hybrid electric vehicle

Headquarters

Heating, ventilating, and air conditioning

Thousand cubic feet

kilovolt-ampere

kilowatt-hour

Levelized cost of energy 


$\begin{array}{ll}\text { LED } & \text { Light-emitting diode } \\ \text { MMBtu } & \text { One million British thermal units } \\ \text { MSW } & \text { Municipal solid waste } \\ \text { MW } & \text { Megawatt } \\ \text { MWe } & \text { Megawatt-electrical } \\ \text { MWh } & \text { Megawatt-hour } \\ \text { NEPA } & \text { National Environmental Policy Act } \\ \text { NETL } & \text { National Energy Technology Laboratory } \\ \text { NEV } & \text { Neighborhood electric vehicle } \\ \text { NREL } & \text { National Renewable Energy Laboratory } \\ \text { NZEI } & \text { Net zero energy installation } \\ \text { O\&M } & \text { Operations and maintenance } \\ \text { PEM } & \text { Proton exchange membrane } \\ \text { PNNL } & \text { Pacific Northwest National Laboratory } \\ \text { PPA } & \text { Power purchase agreement } \\ \text { PSD } & \text { Potential for Significant Deterioration } \\ \text { PV } & \text { Photovoltaics } \\ \text { RDF } & \text { Refuse-derived fuel } \\ \text { REC } & \text { Renewable energy certificate } \\ \text { SAM } & \text { Solar Advisory Model } \\ \text { SNL } & \text { Sandia National Laboratory } \\ \text { SUV } & \text { Sport utility vehicle } \\ \text { TES } & \text { Thermal energy storage } \\ \text { TMP } & \text { Transportation motor pool } \\ \text { USNORTHCOM } & \text { U.S. Northern Command } \\ \text { VAV } & \text { Variable air volume } \\ \text { VFD } & \text { Variable frequency drive } \\ \text { W } & \text { watt } \\ \text { WTE } & \text { Waste to energy } \\ \text { ZEB } & \text { Zero energy building } \\ & \end{array}$




\section{Table of Contents}

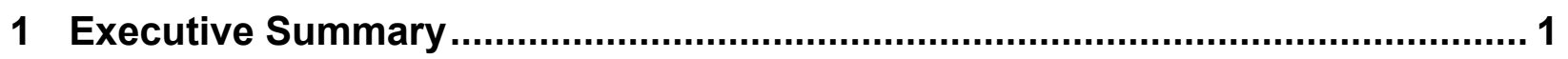

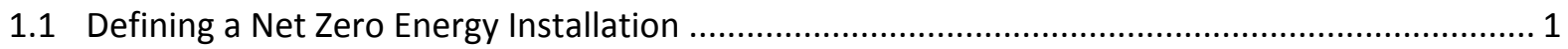

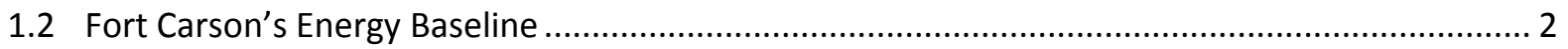

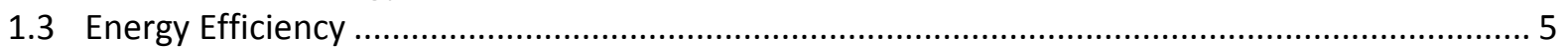

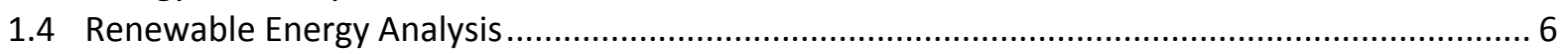

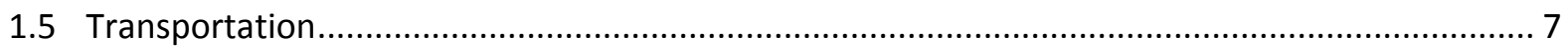

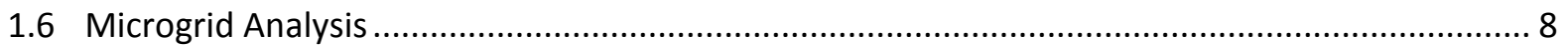

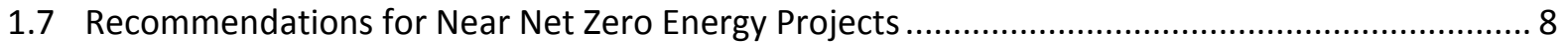

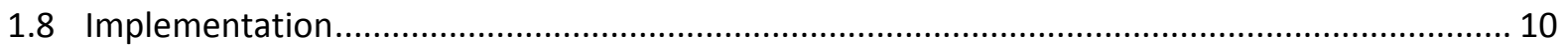

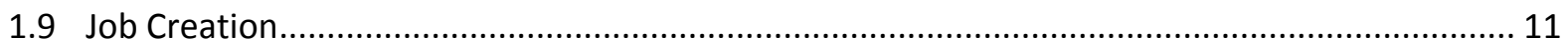

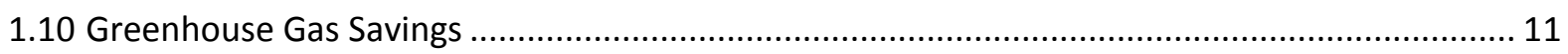

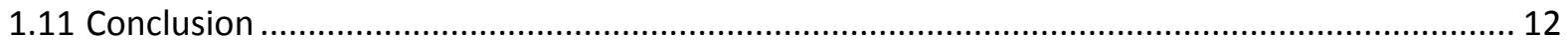

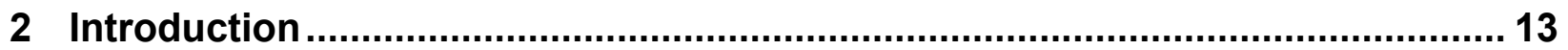

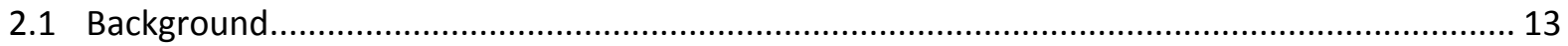

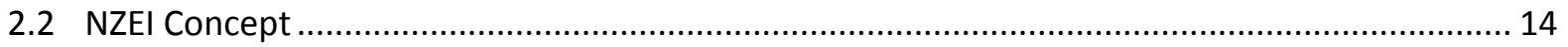

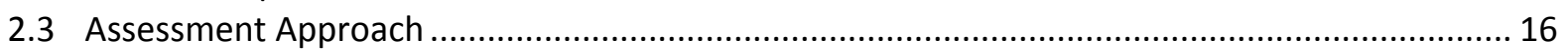

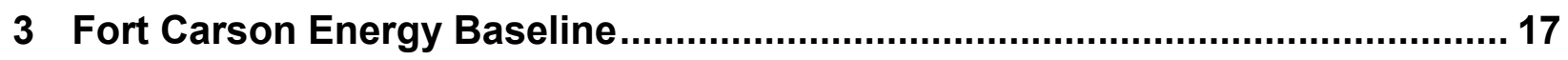

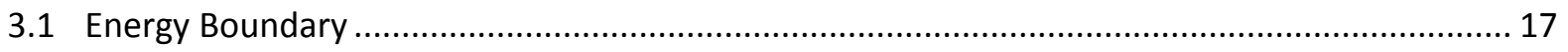

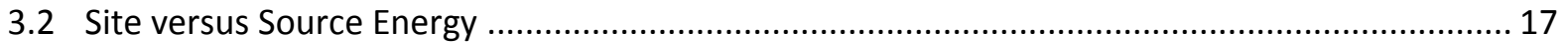

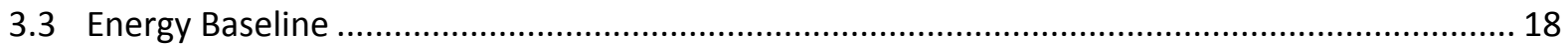

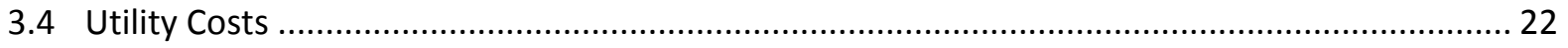

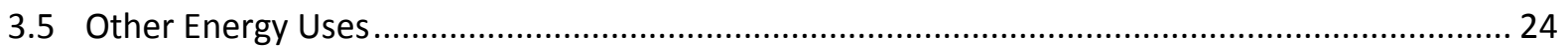

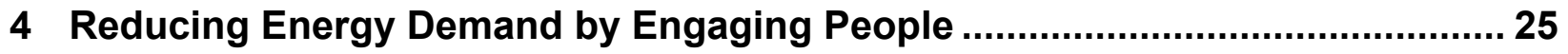

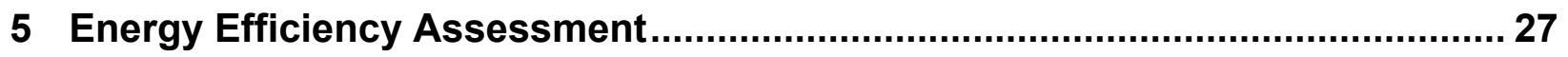

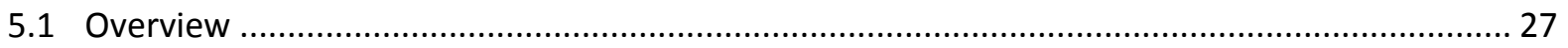

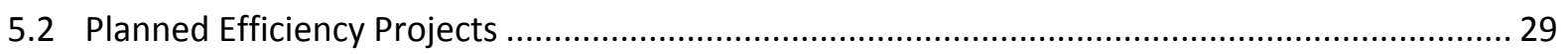

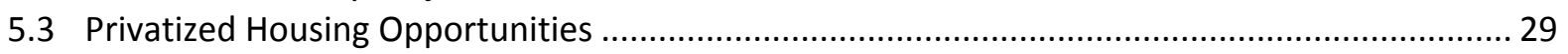

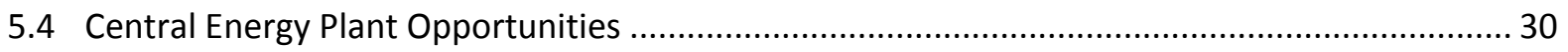

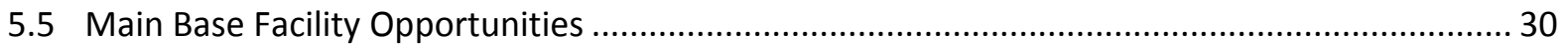

6 Renewable Energy and Additional Load Reduction Projects ........................... 43

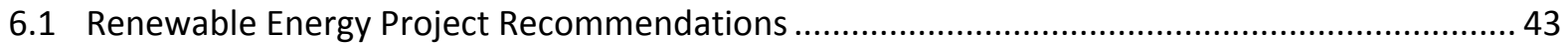

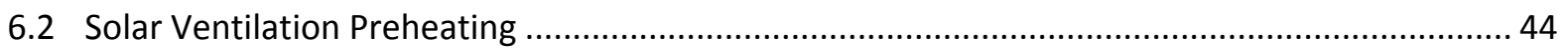

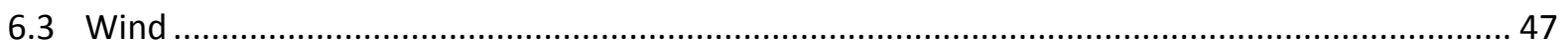

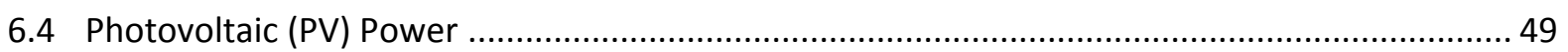

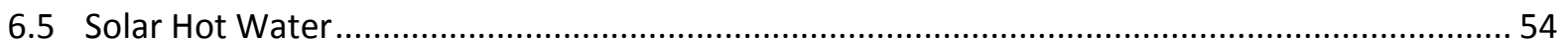

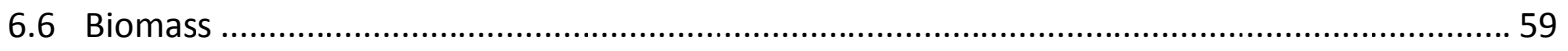

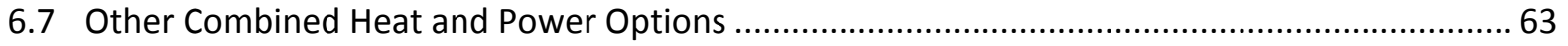

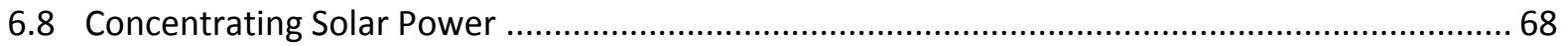

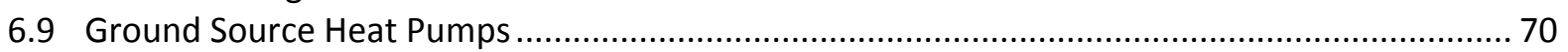

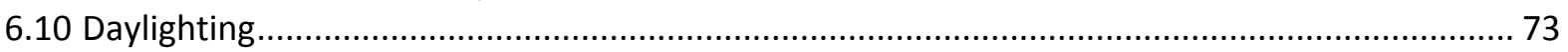

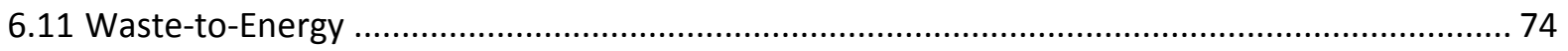

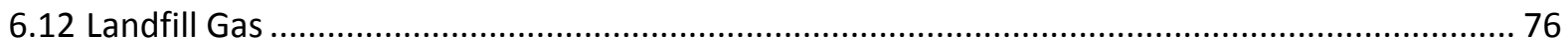

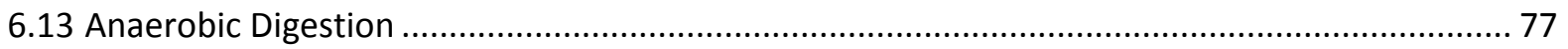




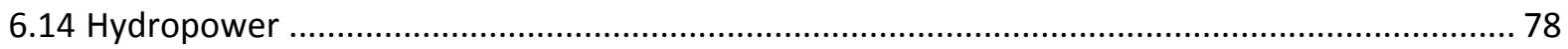

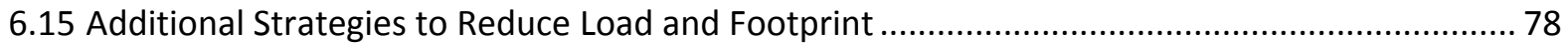

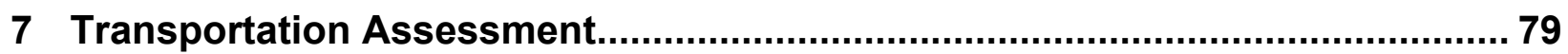

7.1 Fleet Composition and Fuel Use

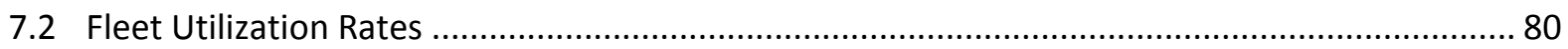

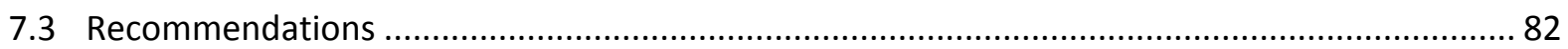

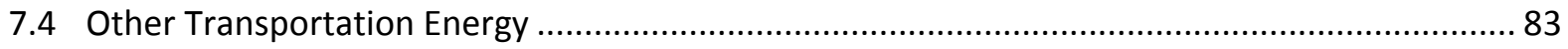

8 Microgrid Assessment and Recommendations ........................................ 86

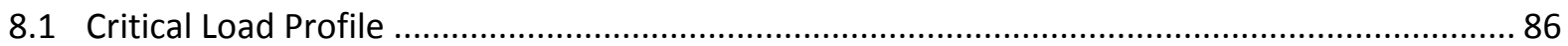

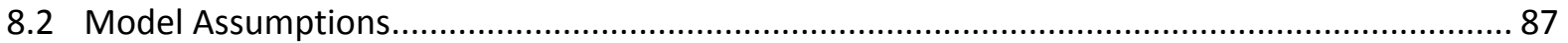

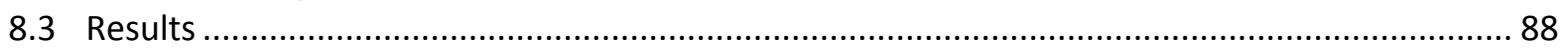

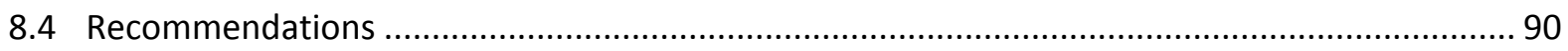

9 Energy Project Recommendations............................................................ 91

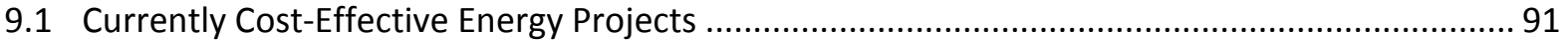

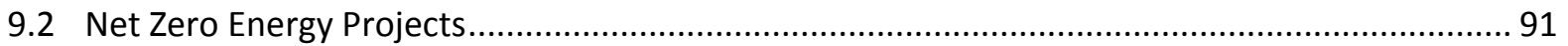

10 Implementation: Project Planning and Financial Assessment ..........................96

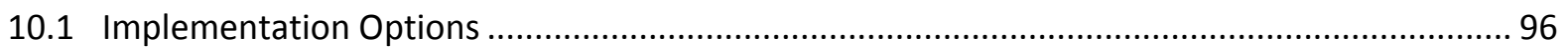

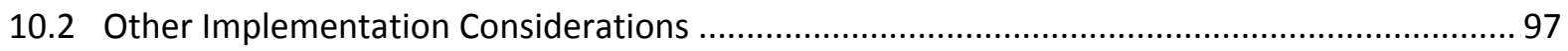

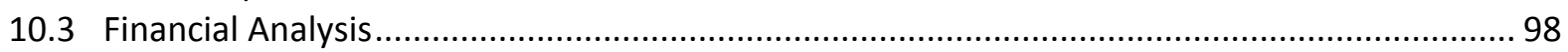

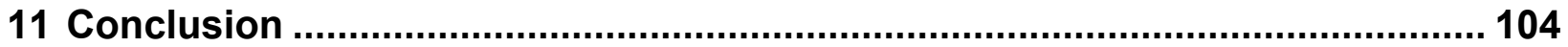

Appendix A. Electric Vehicle Grid Integration .............................................. 105 


\section{List of Figures}

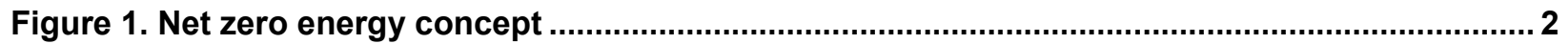

Figure 2. Fort Carson energy use breakdown (percentage of source total Btu) ................................. 3

Figure 3. Actual and projected blended electric rates, 1993-2016 ................................................ 4

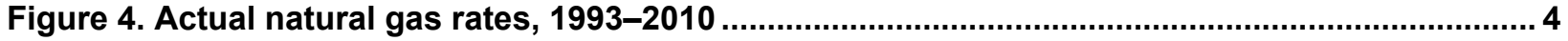

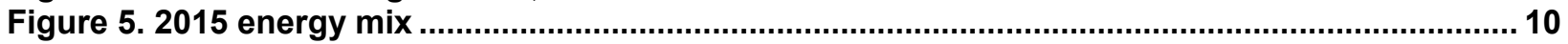

Figure 6. Boundary for Fort Carson energy baseline .................................................................. 17

Figure 7. Fort Carson energy use breakdown (percentage of source total Btu) ............................... 19

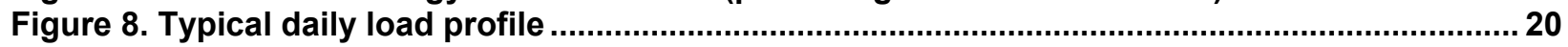

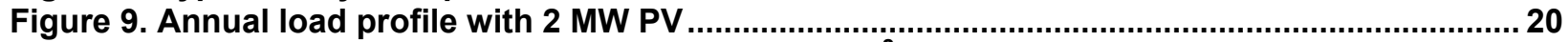

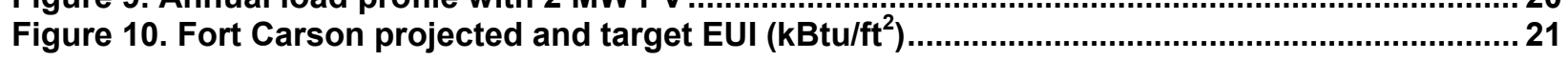

Figure 11. Actual and projected blended electric rates, 1993-2016 ............................................. 23

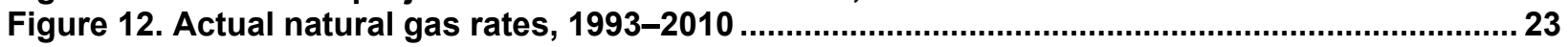

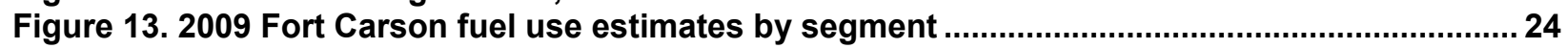

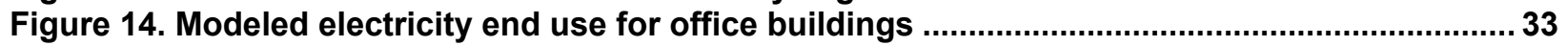

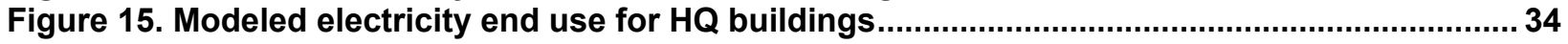

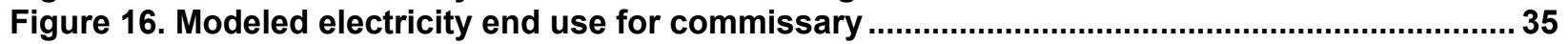

Figure 17. Modeled electricity end use for hospital ........................................................................ 37

Figure 18. Fort Carson barracks (Credit: Ian Metzger, NREL) ..................................................... 38

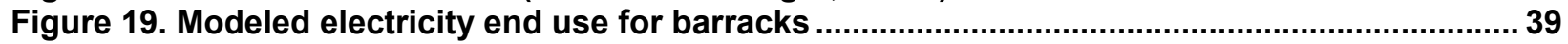

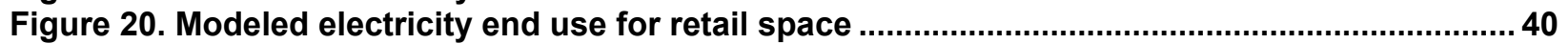

Figure 21. Fort Carson solar walls (Courtesy of Fort Carson) .......................................................... 44

Figure 22. Wind resources in the Fort Carson area ................................................................... 48

Figure 23. Fort Carson 2-MW solar array (Courtesy of Fort Carson) .........................................5 50

Figure 24. Potential rooftop and carport locations in the microgrid area........................................ 51

Figure 25. Solar hot water at Fort Carson indoor pool (Credit: John Leahey, NREL) .......................55

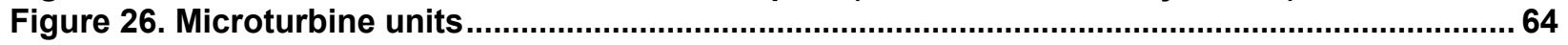

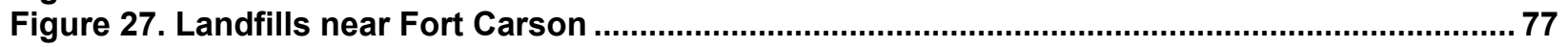

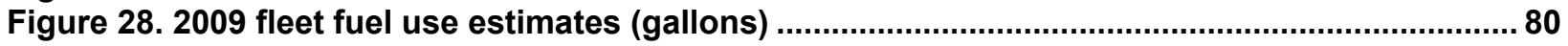

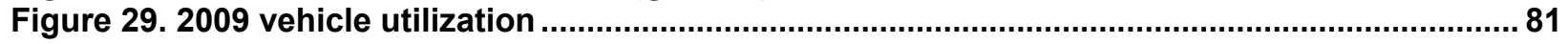

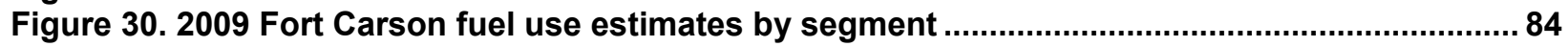

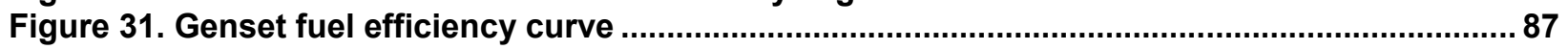

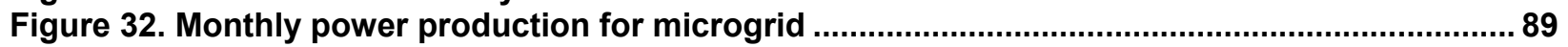

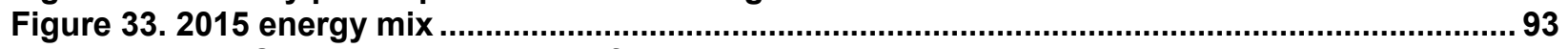

Figure 34. Fort Carson recommended fuel use breakdown ....................................................... 95

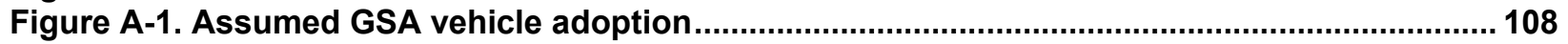

Figure A-2. The Smith Electric Newton all-electric truck, upfitted into one of many different configurable options (Courtesy of www.smithelectric.com) .......................................... 108

Figure A-3. Vehicle technology operational cost comparison ........................................................ 109

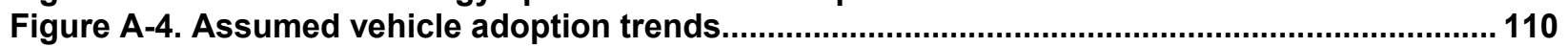

Figure A-5. Starting locations for Fort Carson commuters ..........................................................111

Figure A-6. Commuter distance from Fort Carson (top) and PEV mix (bottom) ............................112

Figure A-7. Commuter and fleet vehicles avaiable at Fort Carson during weekdays....................113

Figure A-8. Base load at Fort Carson with conventional and solar generation mix during

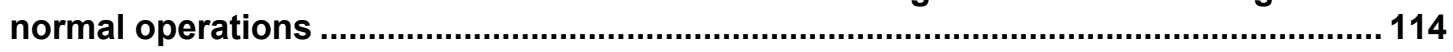

Figure A-9. Emergency demand and generation profile ......................................................... 115

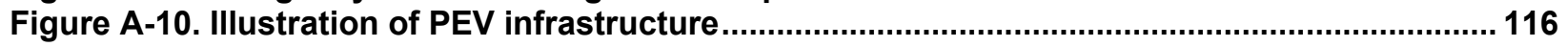

Figure A-11. Opportunity charging at Fort Carson during normal operations .................................118

Figure A-12. Opportunity charging during emergency microgrid operations ................................ 118

Figure A-13. During normal operations, both commuters and motor pool charging smoothes the required ramp rates for conventional generation..................................................119

Figure A-14. Charging at ideal times supplies plenty of range for return commutes..................... 120

Figure A-15. Controlled charging helps to slow the drop-offs in demand during normal operations . 
Figure A-16. Charging smoothes the aggregated load profile during normal operations

Figure A-17. Charge management can help buffer steep power fluctuations

during emergency operations

Figure A-18. Charging at ideal times supplies full range for all electric trucks during emergency operations

Figure A-19. Generators receive little benefit from an electric truck fleet during emergency operations

Figure A-20. V2G enabled load optimization and peak shaving during normal grid operations.... 125

Figure A-21. Charging utilizes primarily solar power while V2G offsets fossil fuels

Figure A-22. With V2G each commuter exchanges relatively little energy while fleet vehicles manage nighttime and weekend loads.

Figure A-23. V2G shaved peaks and fills valleys in the generator load profiles during normal operations

Figure A-24. Comparison of generation with and without PEVs exhibits their effect and potential benefits

Figure A-25. Microgrid management of electric fleet truck V2G helps stabilize unpredictability of load demands and renewables supply

Figure A-26. Electric vehicles can help maintain emergency generators at optimal operating conditions

Figure A-27. Battery state of charge fluctuations during emergency V2G cycle roughly once per day

Figure A-28. V2G extended delay time and reduced overall ramping of generators during emergency operations

Figure A-29. Even a small fleet of motor pool PEVs enabled gradual ramping of loads during emergency operations when compared with the baseline scenario.

Figure A-30. Scalable renewable PEV energy management component for microgrids 


\section{List of Tables}

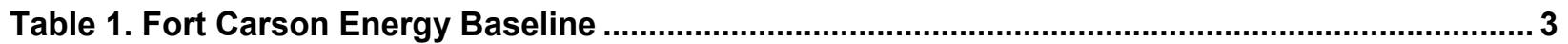

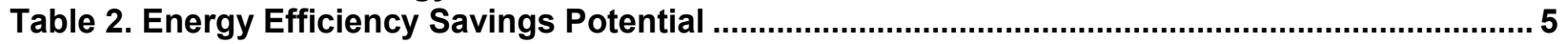

Table 3. Renewable Energy Technologies: Potential Energy Savings and Payback Period .............. 6

Table 4. Energy Mix to Meet the Critical Load for a Microgrid System ............................................. 8

Table 5. Near Net Zero Energy Project Recommendations ................................................................ 9

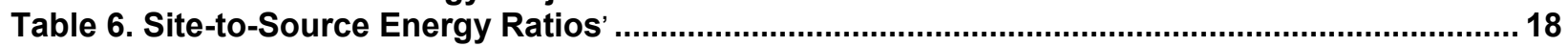

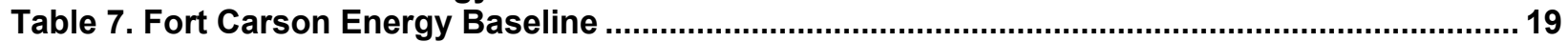

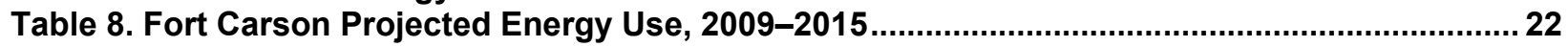

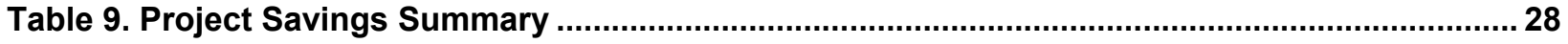

Table 10. Projected Savings of Several Energy Conservation Measures ......................................... 41

Table 11. Renewable Energy Technologies: Potential Energy Savings and Payback Period .......... 43

Table 12. Potential Candidates for Solar Ventilation Preheating Systems ...................................... 45

Table 13. Solar Ventilation Preheating Financial Estimate ............................................................... 47

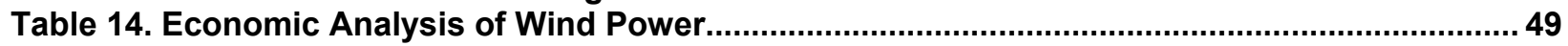

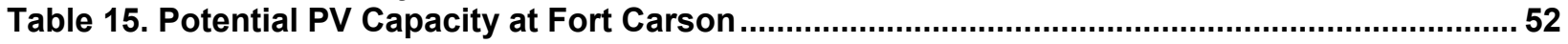

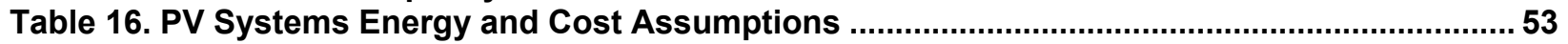

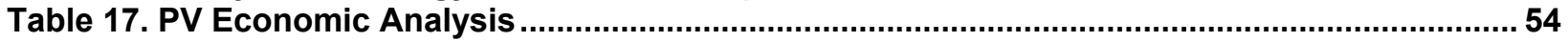

Table 18. Potential Candidates for Solar Hot Water System ......................................................... 56

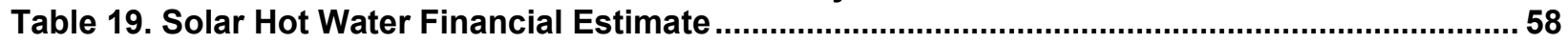

Table 20. Biomass and Alternative Methane Fuel Resources near Fort Carson, CO .......................59

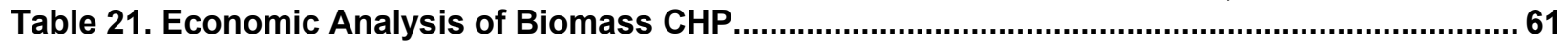

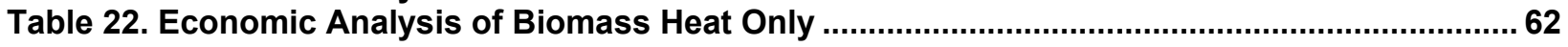

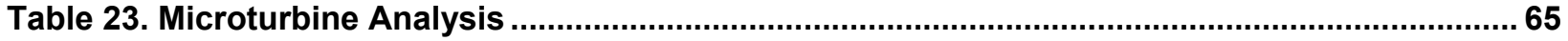

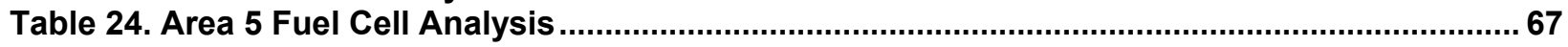

Table 25. CSP Energy Generation and Costs........................................................................... 70

Table 26. Potential Energy Savings from Ground Source Heat Pumps ............................................ 72

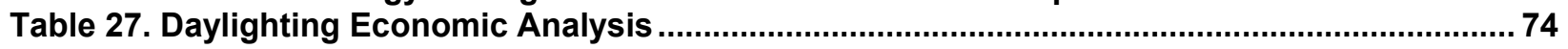

Table 28. Economic Analysis of Waste-to-Energy Plant............................................................. 75

Table 29. 2009 Fleet Summary by Vehicle Type and Fuel Type ........................................................ 79

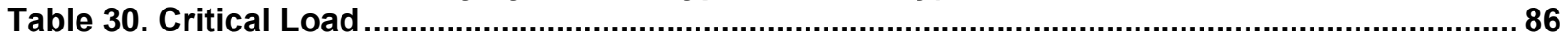

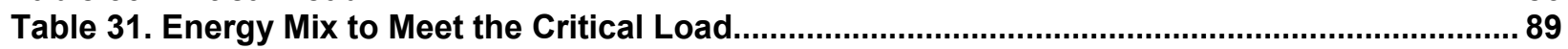

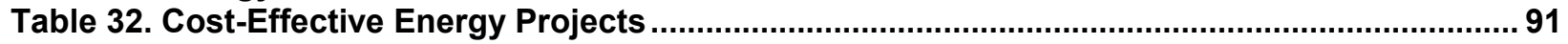

Table 33. Recommended Projects to Achieve Near Net Zero Energy In 2015 ................................. 92

Table 34. Renewable Energy Incentives ................................................................................... 98

Table 35. Initial Cost, O\&M, Rebate, and REC Sale Components ................................................. 100

Table 36. Financial Analysis of 2015 Near Net Zero Recommendations........................................ 101

Table A-1. Modeled Vehicle Characteristics............................................................................... 107

Table A-2. Electric Truck Options Available on the 2010 GSA Schedule........................................ 108

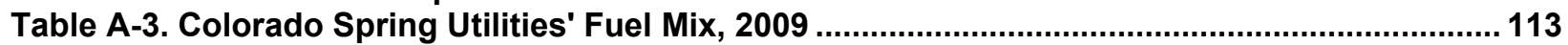




\section{Executive Summary}

The U.S. Department of Defense (DoD) has long recognized the strategic importance of energy to its mission, and is working to reduce energy consumption, as well as to enhance energy security by drawing on local clean energy sources. A recent Defense Science Board report stated that critical military missions are at a high risk of failure in the event of an electric grid failure. ${ }^{1}$ The development of on-site renewable energy supplies can reduce this risk, and may become an increasingly important strategic concern. Renewable energy can also contribute to improved security of the energy supply and of the site, decreased or more predictable energy costs, and responsiveness to energy-related Federal or DoD mandates.

DoD's U.S. Northern Command (USNORTHCOM) has partnered with the National Renewable Energy Laboratory (NREL) to assess opportunities for increasing energy security through renewable energy and energy efficiency at Front Range installations. On the basis of the installation's strong history of energy advocacy and extensive track record of successful energy projects, USNORTHCOM selected Fort Carson to serve as the prototype installation for net zero energy assessment and planning. NREL performed a comprehensive assessment to appraise the potential of Fort Carson to achieve net zero energy status through energy efficiency, renewable energy, and electric vehicle integration. This report summarizes the results of the assessment and provides energy recommendations.

This study is part of a larger DOE cross-laboratory effort that also includes an assessment of renewable opportunities at seven other DoD Front Range installations, a microgrid design for Fort Carson critical loads and an assessment of regulatory and market-based barriers to a regional secure smart grid.

\subsection{Defining a Net Zero Energy Installation}

This report defines a net zero energy installation (NZEI) as follows:

A net zero military installation produces as much energy on-site from renewable energy generation, or through the on-site use of renewable fuels, as it consumes in its buildings, facilities, and fleet vehicles.

Net zero energy is a concept of energy self-sufficiency based on minimizing demand and using local renewable energy resources. A complete net zero solution considers all uses of energy within an installation for buildings, transportation, community infrastructure, and industry. NREL's net zero energy assessment for Fort Carson focused on five areas:

1. An energy baseline

2. Energy efficiency improvements

3. Renewable energy potential

4. Electrical systems analysis

5. Transportation fuel use analysis

\footnotetext{
${ }^{1}$ More Fight Less Fuel, Defense Science Board Report. February 2008. www.acq.osd.mil/dsb/reports/ADA477619.pdf. Accessed May 2010.
} 
Figure 1 shows the phased progression from a typical installation or community, to an installation that has a reduced energy load, to a renewably powered installation.

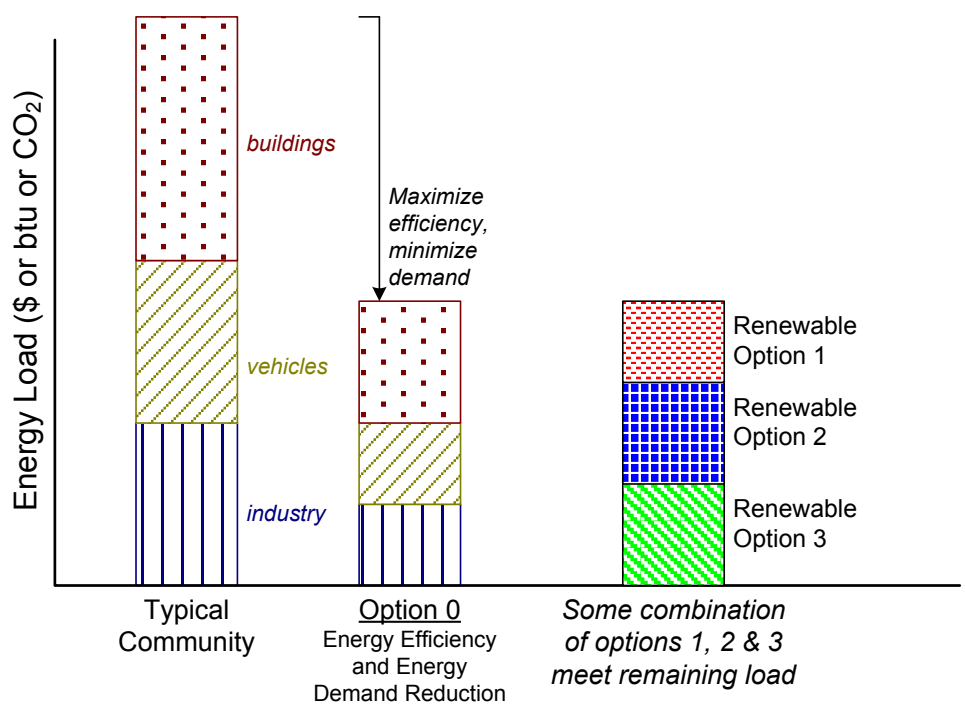

Figure 1. Net zero energy concept

\subsection{Fort Carson's Energy Baseline}

The first step in an NZEI assessment is to determine an energy baseline. The baseline provides an analysis of current energy consumption on base. It gives planners and managers a metric to measure progress against. Fort Carson's energy baseline includes all energy use in buildings, facilities, and fleet vehicles on the main base. The baseline does not include energy use at Pinon Canyon or Turkey Creek. Table 1 shows Fort Carson's energy baseline. 
Table 1. Fort Carson Energy Baseline

\begin{tabular}{|l|r|r|r|r|}
\hline \multirow{2}{*}{\begin{tabular}{l} 
Energy Source \\
\cline { 2 - 4 }
\end{tabular}} & $\begin{array}{r}\text { Site Energy } \\
\text { (Variable units) }\end{array}$ & $\begin{array}{r}\text { Site Energy } \\
\text { (MMBtu) }\end{array}$ & $\begin{array}{r}\text { Source Energy } \\
\text { (MMBtu) }\end{array}$ \\
\hline Buildings and Facilities & $164,406,919 \mathrm{kWh}$ & 560,956 & $1,569,556$ \\
\hline Electricity & $1,137,540 \mathrm{KCF}$ & 927,095 & $1,012,388$ \\
\hline Natural Gas & & $1,488,052$ & $2,581,944$ \\
\hline Total Building Energy Use & 77,799 gallons & 8,558 & 10,158 \\
\hline Fleet Fuel & 53,051 gallons & 7,321 & 8,478 \\
\hline Gasoline & 126,152 gallons & 11,089 & 13,163 \\
\hline Diesel & 19,497 gallons & 2,435 & 2,659 \\
\hline E85 & & 29,403 & 34,458 \\
\hline Compressed Natural Gas & & & \\
\hline Total Fleet Energy Use & & $\mathbf{1 , 5 1 7 , 4 5 5}$ & $\mathbf{2 , 6 1 6 , 4 0 2}$ \\
\hline Total & &
\end{tabular}

The total baseline energy usage at Fort Carson is 1.5 million site MMBtu, or 2.6 million source MMBtu. Electricity and natural gas account for most of this usage, with a small portion going to fleet fuel, as Figure 2 shows.

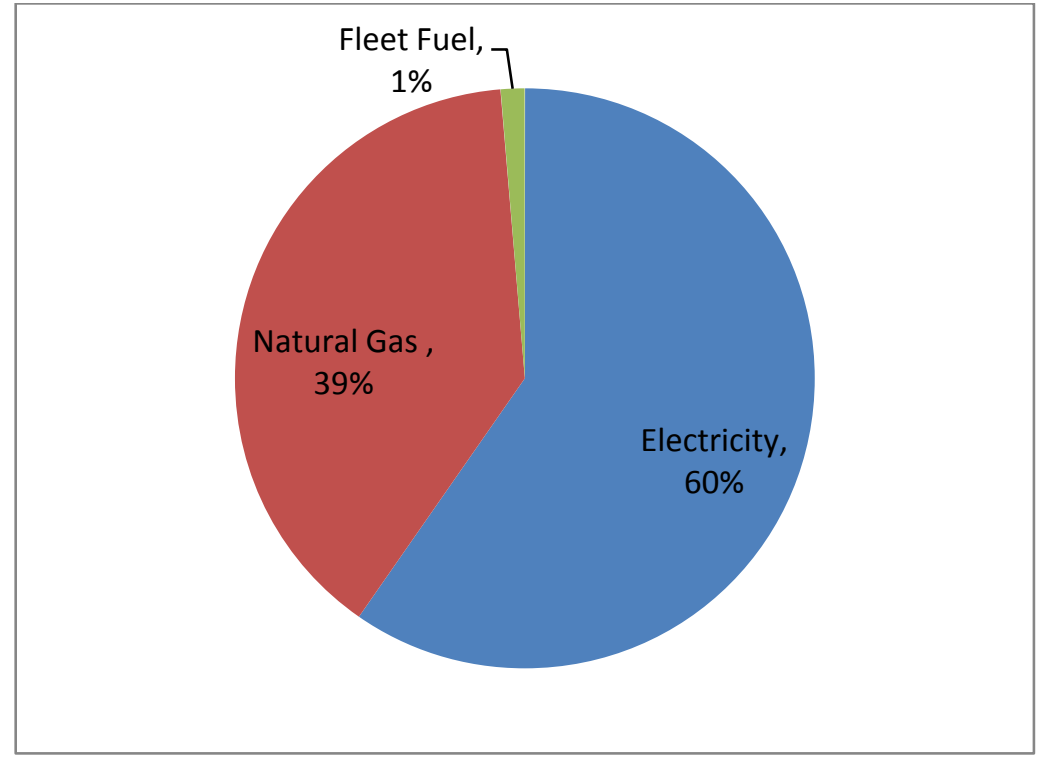

Figure 2. Fort Carson energy use breakdown (percentage of source total Btu) 
Among the more important factors in determining the economic viability of investments in energy efficiency or renewable energy are energy costs. Figure 3 and Figure 4 show how utility prices are expected to change over the next six years. Colorado Springs Utilities (CSU) is projecting rate increases of 12\%/year for 2011-2016. At this rate, electric prices would double from 2009's $\$ 0.05 / \mathrm{kWh}$ to $\$ 0.10 / \mathrm{kWh}$ in 2016 .

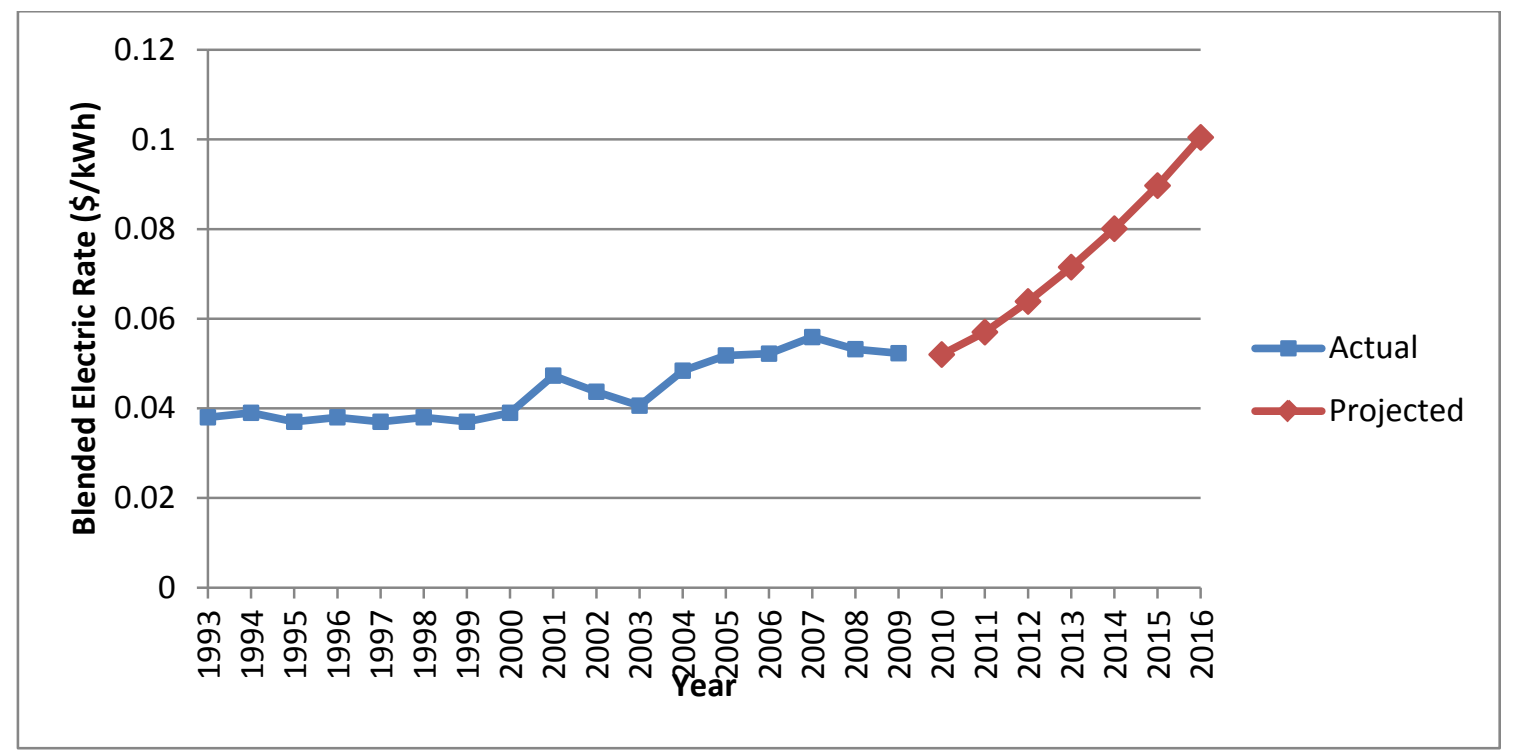

Figure 3. Actual and projected blended electric rates, 1993-2016

Natural gas rate projections were not available, but the historical trend shows natural gas rates increasing from \$5.44/MMBtu in 2009 to more than \$9.00/MMBtu by 2016.

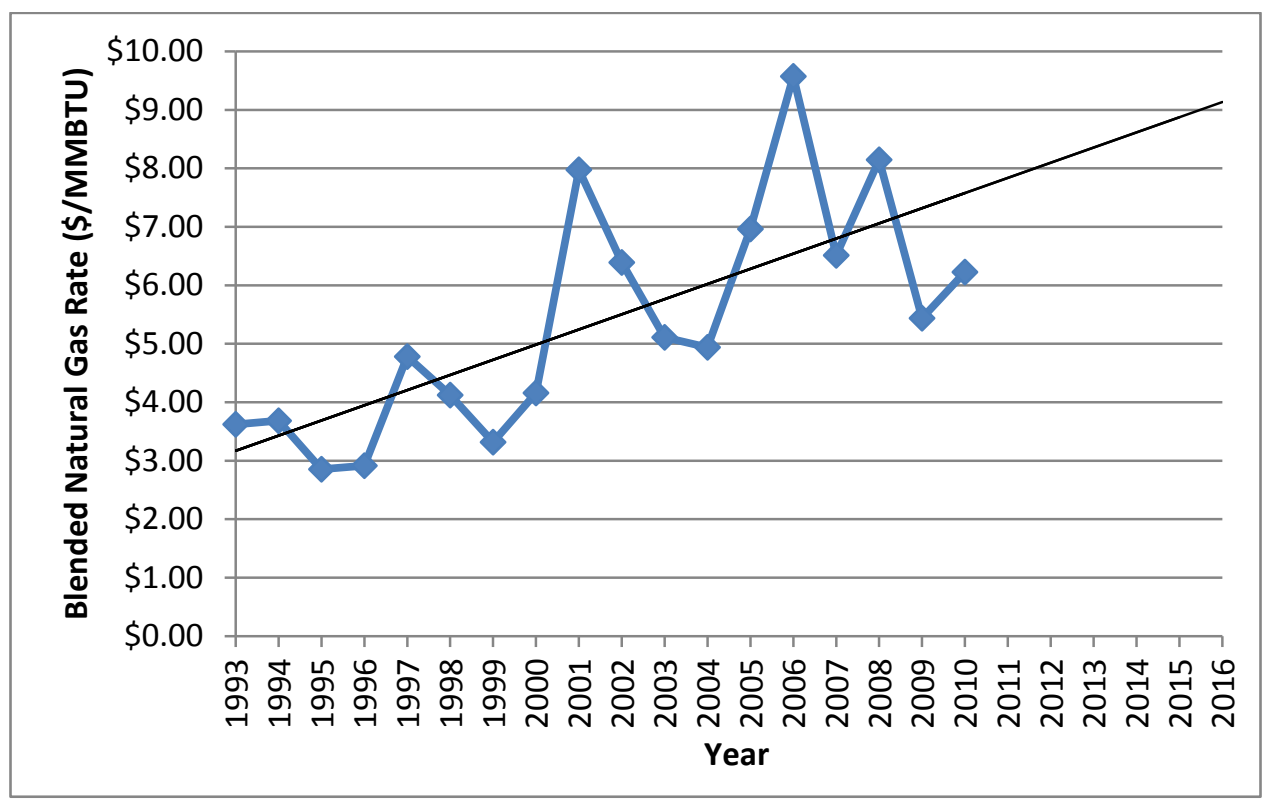

Figure 4. Actual natural gas rates, 1993-2010 


\subsection{Energy Efficiency}

The second step in a net zero energy analysis is to evaluate the potential for reductions in energy use through improvements in energy efficiency. Through discussion with base personnel, analysis of previous energy audits, and modeling of typical buildings, NREL estimated the energy efficiency savings potential of the base. Table 2 summarizes the potential energy savings at Fort Carson, which totals $26.7 \%$ electrical load reduction, $17.2 \%$ natural gas load reduction, and $20.3 \%$ overall energy reduction.

Table 2. Energy Efficiency Savings Potential

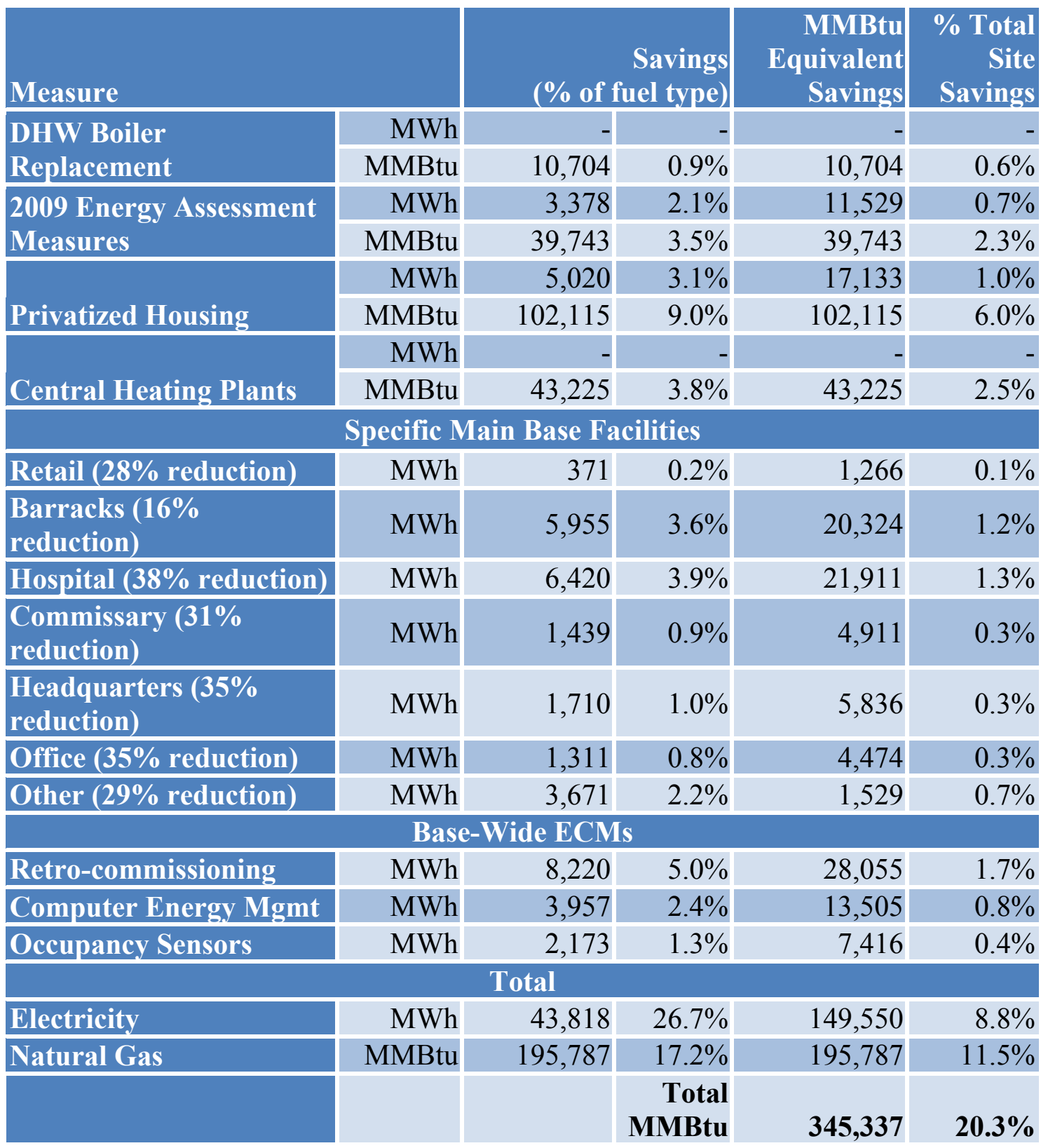




\subsection{Renewable Energy Analysis}

After assessing energy use reduction opportunities at Fort Carson, NREL evaluated the potential for renewable energy generation to meet energy needs that would remain after any energy efficiency improvements were implemented. Table 3 summarizes the renewable energy technologies analyzed, including size, potential energy savings, and simple payback period.

Table 3. Renewable Energy Technologies: Potential Energy Savings and Payback Period

\begin{tabular}{|l|r|r|r|r|}
\hline & Evaluated Size & $\begin{array}{r}\text { Potential Site } \\
\text { Energy } \\
\text { Savings } \\
\text { (MMBtu) }\end{array}$ & $\begin{array}{r}\text { Potential Source } \\
\text { Energy Savings } \\
\text { (MMBtu) }\end{array}$ & $\begin{array}{r}\text { Simple } \\
\text { Payback } \\
\text { Period (years) }\end{array}$ \\
\hline $\begin{array}{l}\text { Solar Ventilation } \\
\text { Preheating }\end{array}$ & $88,050 \mathrm{ft}^{2}$ & 26,353 & 28,777 & 15 \\
\hline Wind & $10.5 \mathrm{MW}$ & 61,304 & 171,528 & 16 \\
\hline Photovoltaics (PV) & $42.43 \mathrm{MW}$ & 216,178 & 604,865 & $26-46$ \\
\hline Biomass Heat Only & $30 \mathrm{MMBtu} / \mathrm{hr}$ & 160,000 & 174,720 & 29 \\
\hline $\begin{array}{l}\text { Solar Water } \\
\text { Heating }\end{array}$ & $43,441 \mathrm{ft}^{2}$ & 20,887 & 22,809 & 30 \\
\hline $\begin{array}{l}\text { Concentrating } \\
\text { Solar Power (CSP) }\end{array}$ & $10 \mathrm{MW}$ & 81,888 & 229,123 & 42 \\
\hline Fuel Cell & $1400 \mathrm{~kW}$ & $-8,000$ & 45,856 & 43 \\
\hline $\begin{array}{l}\text { Ground Source } \\
\text { Heat Pump (GSHP) }\end{array}$ & $18,150 \mathrm{tons}$ & 378,391 & 178,463 & 57 \\
\hline Daylighting & $770,000 \mathrm{ft}^{2}$ & 35,053 & 38,278 & 147 \\
\hline Biomass CHP & $7 \mathrm{MW}$ thermal, & 283,771 & 452,792 & Negative \\
\hline Microturbine & $60 \mathrm{~kW}$ & $-1,428$ & 389 & Negative \\
\hline $\begin{array}{l}\text { Waste-to-Energy } \\
\text { (WTE) }\end{array}$ & $670 \mathrm{~kW}$ & 15,333 & 42,902 & Negative \\
\hline Landfill Gas & 0 & 0 & 0 & N/A \\
\hline $\begin{array}{l}\text { Anaerobic } \\
\text { Digestion }\end{array}$ & 0 & 0 & 0 & N/A \\
\hline Hydro Power & & 0 & 0 & N/A \\
\hline
\end{tabular}

This analysis shows that renewables currently have long payback periods at Fort Carson, due to the relatively low cost of fossil energy in the region. The analysis found that solar ventilation preheating, biomass, and solar hot water are the most cost-effective heating technologies. Wind and photovoltaics (PV) are the most cost-effective electric technologies. Projected increases in energy prices could improve the economics of renewable projects. 


\subsection{Transportation}

The analysis evaluated options for reducing transportation energy use at Fort Carson. Recommendations include:

- Track fleet fuel use. Tracking allows better management of fuel use and fuel savings opportunities.

- Right-size the fleet. Reduce the total number of vehicles in the fleet and allocate savings to other fleet needs.

- Switch to alternative fuel vehicles. Fort Carson has done an excellent job incorporating alternative fuel vehicles in its fleet, but there is a potential for additional transportation energy savings. Nearly half of the Fort Carson fleet is fueled by traditional gasoline or diesel, consuming an estimated 130,000 gallons of petroleum annually. If Fort Carson replaced half of the gasoline vehicles with flex fuel vehicles (FFV) that run on E85, and if personnel consistently fueled them with E85, this would displace nearly 40,000 gallons of gasoline consumption per year. If biodiesel were used consistently in the diesel vehicle fleet, Fort Carson could displace another 10,000 gallons of petroleum per year.

- Use alternative fuel. Always use E85 in FFVs and consider a biodiesel program for diesel vehicles.

- Hybrids and electric vehicles (HEVs). Consider HEVs when other alternative fuel vehicle technologies are not available to meet the mission.

- Evaluate tactical and commuter fuel use. Tactical and commuter fuel make up 97\% of the transportation energy used on Fort Carson, dwarfing Federal fleet fuel use. If commuter fuel use were to be reduced by 5 percent, the resultant 350,000 gallons of petroleum displaced would more than exceed the fuel used by the fleet. While commuter and tactical fuel use was not part of this analysis, we recommend evaluating policies that could reduce commuter fuel use, including alternative work schedules and locations, staggered start times to reduce idling at the gate, and ride sharing. We also recommend identifying potential operational efficiencies to reduce tactical fuel use. 


\subsection{Microgrid Analysis}

In this analysis, we optimized the size of each technology to find the most cost effective solution to meet critical loads of 3-4 MW in an islanded microgrid scenario (that is, with no grid connection). This scenario looked at traditional diesel generation and battery storage in addition to PV, wind, and biomass. Analysis found the optimal solution to be a combination 3.1 MW of biomass, $1 \mathrm{MW}$ of diesel generation, and $500 \mathrm{~kW}$ of PV (see Table 4). The cost of energy (COE) is $\$ 0.17 / \mathrm{kWh}$, compared to a diesel-only COE of $\$ 0.250 / \mathrm{kWh}$. Diesel fuel use decreases $93 \%$ from the diesel-only solution.

Table 4. Energy Mix to Meet the Critical Load for a Microgrid System

\begin{tabular}{|l|r|r|r|}
\hline Component & Size (MW) & Production (kWh/yr) & Production (\%) \\
\hline Biomass & 3.1 & $23,349,642$ & 91 \\
\hline Diesel Generator & 1.0 & $1,552,869$ & 6 \\
\hline PV array & 0.5 & 778,655 & 3 \\
\hline Total & & $25,681,166$ & 100 \\
\hline
\end{tabular}

In a microgrid, the load and generation must match exactly at all times, so consistent baseload sources of power are preferred. The microgrid relies mainly on biomass as the cheapest renewable source of baseload power, and would require a large supply of off-site biomass. To reduce reliance on outside fuel sources such as biomass and diesel, CSP (concentrating solar power) with thermal energy storage could also provide consistent baseload power at a cost of $\$ 0.21 / \mathrm{kWh}$. Forty acres of land near the microgrid area would be required.

\subsection{Recommendations for Near Net Zero Energy Projects}

NREL proposed energy projects to help Fort Carson approach net zero energy. Table 5 shows the projects proposed to meet energy use levels forecasted for 2015. Implementation of these projects would provide $100 \%$ of electrical energy, $88 \%$ of thermal energy, and $57 \%$ of transportation energy from renewable sources. 
Table 5. Near Net Zero Energy Project Recommendations

\begin{tabular}{|c|c|c|}
\hline & $\begin{array}{r}\text { Size } \\
\text { (Variable Units) } \\
\end{array}$ & $\begin{array}{r}\text { Site Energy } \\
(\text { MMBtu) } \\
\end{array}$ \\
\hline \multicolumn{3}{|c|}{ Electric Energy Project Recommendations } \\
\hline Efficiency & $26.70 \%$ & 203,388 \\
\hline Wind & $10.5 \mathrm{MW}$ & 61,304 \\
\hline PV-ground mount ${ }^{\mathrm{a}}$ & $20.2 \mathrm{MW}$ & 100,554 \\
\hline PV-rooftop & $24 \mathrm{MW}$ & 125,580 \\
\hline PV-carport & $28.4 \mathrm{MW}$ & 120,046 \\
\hline CSP & $20 \mathrm{MW}$ & 170,600 \\
\hline $\begin{array}{l}\text { Total renewable electricity } \\
\text { production (MMBtu) }\end{array}$ & & 781,472 \\
\hline 2015 electricity use (MMBtu) & & 781,472 \\
\hline $\begin{array}{l}\text { Percent of electric energy } \\
\text { supplied by renewables } \\
\end{array}$ & & $100 \%$ \\
\hline \multicolumn{3}{|c|}{ Thermal Energy Project Recommendations } \\
\hline Efficiency & $17.20 \%$ & 266,270 \\
\hline Solar vent preheat & $119,748 \mathrm{ft}^{2}$ & 35,841 \\
\hline Solar hot water & $59,080 \mathrm{ft}^{2}$ & 28,406 \\
\hline Biomass heat & $30 \mathrm{MMBtu} / \mathrm{hr}$ & 160,000 \\
\hline GSHP & 24,684 tons & 514,611 \\
\hline $\begin{array}{l}\text { Total renewable thermal } \\
\text { production (MMBtu) }\end{array}$ & & $1,005,128$ \\
\hline $\begin{array}{l}2015 \text { thermal energy use } \\
\text { (MMBtu) }\end{array}$ & & $1,143,335$ \\
\hline $\begin{array}{l}\text { Percent of thermal energy } \\
\text { supplied by renewables }\end{array}$ & & $88 \%$ \\
\hline \multicolumn{3}{|c|}{ Transportation Energy Project Recommendations } \\
\hline $\begin{array}{l}\text { Replace half of gasoline-fueled } \\
\text { vehicles with E85 }\end{array}$ & 40,000 gallons & 4,400 \\
\hline Replace diesel with biodiesel & 10,000 gallons & 1,380 \\
\hline $\begin{array}{l}\text { Continue current renewable } \\
\text { fuel use }\end{array}$ & 126,152 gallons & 11,089 \\
\hline Total renewable fuel use & 176,152 gallons & 16,869 \\
\hline Total fuel use & 276,499 gallons & 29,403 \\
\hline $\begin{array}{l}\text { Percent of fleet energy supplied } \\
\text { by renewables }\end{array}$ & & $57 \%$ \\
\hline
\end{tabular}

a. $2 \mathrm{MW}$ of the required $20.2 \mathrm{MW}$ is already installed at Fort Carson 
Figure 5 shows the 2015 energy mix, if all recommended projects were implemented.

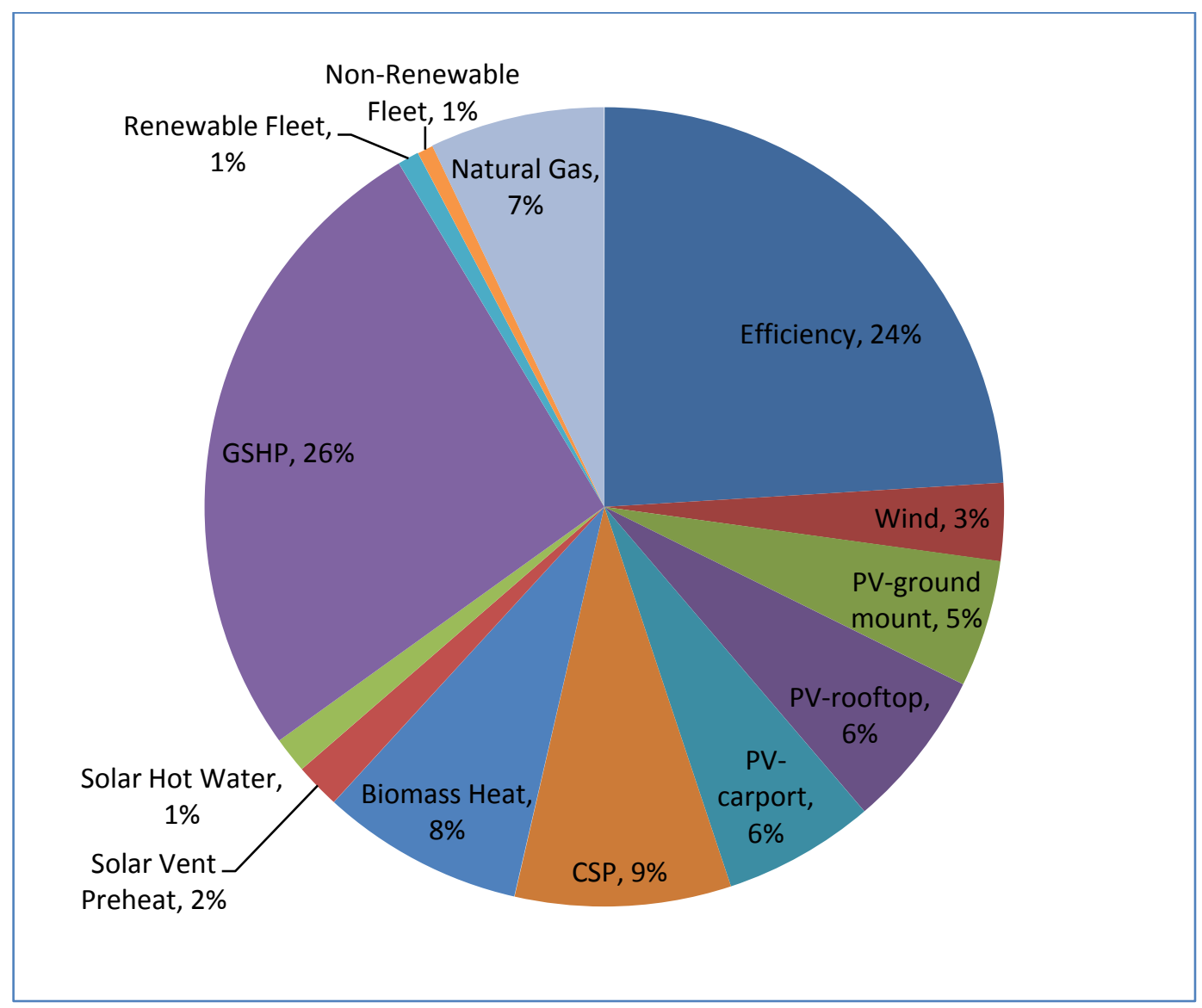

Figure 5. 2015 energy mix

The simple payback for this project is 35 years. The project requires a capital investment of $\$ 842$ million. The net present value after 40 years, without Federal tax rebates, is $\$ 96$ million. The results from this analysis illustrate that, if fossil energy prices rise as predicted, the near net zero energy project recommendations are likely viable over a 40 year project lifetime and would provide reduced energy costs to the base. This analysis is highly dependent on future fossil energy prices, however. If fossil energy prices increase at a lower rate than predicted, net present value could become negative.

\subsection{Implementation}

Fort Carson has several options for implementing energy projects, including energy savings performance contracts (ESPC), utility energy services contracts (UESC), power purchase agreements (PPA), and appropriated funds. Government-owned projects funded through appropriations reduce contractor financing and markup fees, but require upfront capital and would prevent Fort Carson from receiving Federal tax incentives. Government-owned projects would also place an O\&M burden on Fort Carson. By contrast, privately-owned projects would allow Fort Carson to implement renewables without any upfront capital, and with reduced O\&M responsibility. Privately-owned projects would also allow Fort Carson to take advantage of 
Federal tax credits, although some of the money gained in tax credits may go toward contractor financing and markup fees.

Federal energy projects require funding to generate results. Carefully matching available financing mechanisms with specific project needs can make the difference between a stalled, unfunded project and a successful project generating energy and cost savings. FEMP supports Federal agencies in identifying, obtaining, and implementing alternative financing to fund energy projects.

For assistance with ESPCs, contact:

\section{Scott Wolf}

6848 Cooper Point Road NW

Olympia, WA 98502

Phone: 360-866-9163

Fax: 360-866-9683

scott.wolf@ee.doe.gov

For UESCs, contact:

\begin{tabular}{ll}
\hline David McAndrew & Karen Thomas \\
Federal Energy Management Program & National Renewable Energy Laboratory \\
202-586-7722 & $202-488-2223$ \\
david.mcandrew@ee.doe.gov & $\underline{\text { karen thomas } @ \text {,nrel.gov }}$ \\
\hline
\end{tabular}

For PPAs, contact:

\begin{tabular}{ll}
\hline Tracy Logan & Chandra Shah \\
Federal Energy Management Program & National Renewable Energy Laboratory \\
202-586-9973 & $303-384-7557$ \\
tracy.logan@ee.doe.gov & $\underline{\text { chandra.shah@,nrel.gov }}$ \\
\hline
\end{tabular}

For more information about alternative financing, visit the FEMP Financing Mechanisms Web page at www.femp.energy.gov/financing/mechanisms.html.

\subsection{Job Creation}

Implementation of all net zero energy measures identified would results in 7543 job-years, assuming $\$ 92,000$ in initial investment is equal to one job-year.

\subsection{Greenhouse Gas Savings}

Implementation of all net zero energy measures would result in a $\mathrm{CO}_{2}$ reduction of 423,951 tons $\mathrm{CO}_{2} /$ year. 


\subsection{Conclusion}

The NREL analysis shows that Fort Carson has the potential to make significant progress toward becoming a net zero energy installation. If Fort Carson implements recommended energy projects and savings measures, then the base could potentially achieve a $92 \%$ site Btu reduction and a 95\% source Btu reduction. If Fort Carson achieves this status, it will set an example for other military installations, provide environmental benefits, reduce costs, increase energy security, and exceed its goals and mandates. 


\section{Introduction}

\subsection{Background}

The Department of Defense (DoD) has long recognized the strategic importance of energy to its mission, and is working to reduce energy consumption, as well as to enhance energy security by drawing on local clean energy sources. A recent Defense Science Board report stated that critical military missions are at a high risk of failure in the event of an electric grid failure. 2 Failures may occur as a result of malicious activities (for example, physical or cyber attacks) or due to blackouts on an aging electric grid infrastructure. The development of on-site renewable energy supplies can reduce this risk, and may become an increasingly important strategic concern. Renewable energy can also contribute to improved security of the energy supply and of the site. It can decrease energy costs or make them more predictable, as well as increase the base's responsiveness to energy-related Federal or DoD mandates.

In 2008 the DoD and Department of Energy (DOE) defined a joint initiative to address military energy use by identifying specific actions to reduce energy demand and increase use of renewable energy on DoD installations. In light of DoD priorities, early attention was given to the possibility of net zero energy military installations (NZEI), that is, installations that would meet their energy needs with local renewable resources. DoD's U.S. Northern Command (USNORTHCOM) has partnered with the National Renewable Energy Laboratory (NREL) to assess opportunities for increasing energy security through renewable energy and energy efficiency at Front Range installations. Because of Fort Carson's strong history of energy advocacy and extensive track record of successful energy projects, USNORTHCOM selected Fort Carson to be the prototype installation for net zero energy assessment and planning.

NREL's tasking was to perform a comprehensive assessment of Fort Carson's potential to achieve net zero energy status and provide energy project recommendations. This study is the first step in USNORTHCOM's long-term objective to move installations toward energy selfsufficiency and security. The goal is for installations to be capable of meeting their own energy needs for up to six months in the event of a long-term utility power failure. The objectives of this study are to:

- Identify net zero energy opportunities at Fort Carson and provide energy project recommendations

- Assess electric grid vehicle integration opportunities at Fort Carson.

This study is part of a larger cross-laboratory effort that will also include assessing renewable opportunities at seven other DoD Front Range installations, a microgrid design for Fort Carson's critical loads, and an assessment of regulatory and market-based barriers to the development of a regional secure smart grid.

\footnotetext{
${ }^{2}$ More Fight Less Fuel, Defense Science Board Report. February, 2008. www.acq.osd.mil/dsb/reports/ADA477619.pdf. Accessed May 2010.
} 


\subsection{NZEl Concept}

Net zero energy is a concept of energy self-sufficiency that tries to minimize energy demand and increase the use of use of local renewable energy resources. In principle, a net zero energy installation should reduce its load through conservation and energy efficiency (typically the most cost effective measure, one that provides the highest returns per dollar spent), then meet the remaining load through on-site renewable energy. Defining a net zero energy military installation is complicated by the need to consider-in addition to energy used by individual buildings, public facilities, and infrastructure-the energy used for various forms of transportation, as well as mission-specific energy requirements, such as tactical fuel demands. This report uses the following definition:

A net zero energy military installation produces as much energy on-site from renewable energy generation or through the on-site use of renewable fuels, as it consumes in its buildings, facilities, and fleet vehicles.

The following bullet points provide a more detailed explanation of the net zero concept and its components.

- Net Zero means that the energy produced on-site over the period of a given year is equal to the installation's energy demand. This implies a connection to a local power grid, which, in a sense, "banks" the energy. Thus on-site renewable resources, such as solar energy systems, may produce energy greater than that used by the installation during the day, and then feed that excess energy into the public grid. At night, when the solar system is not producing energy, the installation can pull the electricity required from the public grid. If the installation contributes as much or more than it consumes, it is net zero.

- Energy consumption may be in the form of electricity, steam, or hot water, or the direct use of fuel.

- A military installation may be a contiguous area or may comprise separate areas. Assessments of the energy use of the installation must include all activities within the defined boundaries, regardless of whether their energy is managed by the base energy manager, or paid for by different agencies.

- A facility is any structure on a military installation that is not a building or fleet vehicle, such as a swimming pool or area lighting.

- On-site energy production was a key focus for the assessment team. The team considered both energy generated on-site from renewable sources and renewable fuel used on-site. The set of on-site renewable energy sources followed standard DOE practice: commercially available solar (photovoltaic, concentrating solar power, water heating, and space heating), wind, geothermal, biomass and hydropower systems, and electricity or heat generated from biogas produced in on-site landfills or by burning the installation's solid waste (waste-to-energy).

- Renewable fuels include various forms of biomass (wood waste, agricultural byproducts); natural gas produced, for example, from external landfills or as a byproduct of sewage processing; and various renewable transportation fuels (ethanol, E85, biodiesel). 
- As used here, the net zero energy concept does not include non-primary energy imported from offsite (for example, electricity from a local offsite renewable source), or purchases of renewable energy certificates (RECs). This provision is in keeping with the NZEI concepts' emphasis on meeting energy needs with local resources.

- It is possible to measure energy consumption at an installation in several ways. As adapted from Torcellini et al., ${ }^{3}$ possible measurement approaches include:

○ Net Zero Site Energy. Site energy refers to energy used by the installation that is accounted for at the site, for example, as indicated by building electricity and gas meters. This approach is generally straightforward, but omits transmission losses to bring energy to the site.

○ Net Zero Source Energy. Source energy refers to the primary energy used to generate and deliver the energy to a site, for example, by a local utility generation and transmission system. For transportation fuel, source energy would include a multiplier to account for the energy required to transport the fuel to the fueling station.

○ Net Zero Energy Costs. This approach compares 1) the amount of money that the utility pays the installation for renewable energy generated on-site and exported to the grid with 2) the amount the installation pays the utility for energy used over a year.

○ Net Zero Energy Emissions. Here the installation attempts to produce on-site at least as much renewable energy as it currently uses from offsite nonrenewable energy sources each year, thus offsetting the emissions of offsite energy production.

- The project team judged net zero source energy to be the most representative measure of primary energy consumption, and selected it as the basis for energy accounting for NZEI analysis.

- These calculations include base transportation fuel use with the following limitations: all transportation fuel consumption data is gathered for the purpose of establishing an installation's total footprint, data permitting. The total can include fuel use by Federal Government ground fleet vehicles, fuel associated with commercial air travel for official business, fuel used in personnel commuting, and tactical fuel use. However, only fuel use of the Federal Government fleet is addressed in the NZEI analysis. Potential fuel reduction measures include converting to electric vehicles, using electricity generated on-site from renewable sources, or the use of renewable fuels in fleet vehicles.

- Because the DoD's capability to significantly affect energy used in commercial air travel and by commuters is limited to minimizing trips, encouraging carpooling or telecommuting (where possible), or providing electric vehicle charging stations, these categories are not considered. Tactical

\footnotetext{
${ }^{3}$ Torcellini et al. "Zero Energy Buildings (ZEB): A Critical Look at the Definition." Golden, Colorado: National Renewable Energy Laboratory. 2006.
} 
fuel requirements are not addressed in the assessment since renewable fuel alternatives are not yet commercially available. DoD can (and does) examine training requirements and opportunities to use simulators instead of real tanks/personnel carriers, aircraft, ships and submarines. The department can also explore logistical variations in theater that can also reduce fuel use, but this report does not address these options.

Again, the net zero energy installation concept can be seen as a useful entry point into exploring demand reduction through human action and energy efficiency technology, and then meeting the remaining energy needs with local renewable energy resources. Some installations will be able to exceed net zero status to become net energy producers, while others will not be able to approach it. In fact, a net zero goal, too strictly applied, can lead to solutions that make poor sense from an economic or other perspectives. But assessment of a site's net zero potential, combined with consideration of the other constraints identified in the preceding section, provide a disciplined basis for identifying an optimal energy strategy that is tailored to the requirements of each site.

\subsection{Assessment Approach}

The approach developed for this assessment includes seven steps, which we summarize here and then address in detail in the remaining chapters of this report.

1. Establish Fort Carson Energy Baseline. Identify the installation mission, geographic boundaries, and any special energy requirements (e.g., reliability, performance in emergency situations, etc.). Summarize annual energy used by all identified sources supporting the mission.

2. Demand Reduction through Human Action. Identify approaches to minimizing wasted energy while maintaining or improving the quality of mission execution.

3. Energy Efficiency Assessment. Identify specific on-site energy efficiency projects and their effect on installation energy consumption.

4. Renewable Energy and Load Reduction Assessment. Identify projects exploiting on-site renewable energy or employing renewable fuels on-site for electricity and/or heat production.

5. Transportation Assessment. Identify projects to reduce and replace fossil fuel use in fleet vehicles.

6. Microgrid Assessment. Outline the characteristics of a smart microgrid to support emergency operations in the event of a public grid outage. Identify the impacts of renewable energy projects on the microgrid.

7. Energy Project Recommendations. Recommend a set of energy projects and implementation options. Calculate the extent to which the installation can approach net zero energy status. 


\section{Fort Carson Energy Baseline}

The first step in an NZEI assessment is to determine an energy baseline. The baseline is used to evaluate net zero energy potential and includes energy use in on-site buildings, facilities, and fleet vehicles.

\subsection{Energy Boundary}

Working with Fort Carson staff, NREL defined the geographical boundary of the installation as the energy boundary for Fort Carson's energy baseline. Figure 6 shows the energy boundary outlined in yellow. The majority of energy usage occurs in the developed area at the north tip of the installation, outlined in red. The rest of the base is mainly open land used for training activities. The energy baseline does not include energy use at the Turkey Creek Recreation Area south of the main site or the Pinon Canyon site near Trinidad, Colorado.

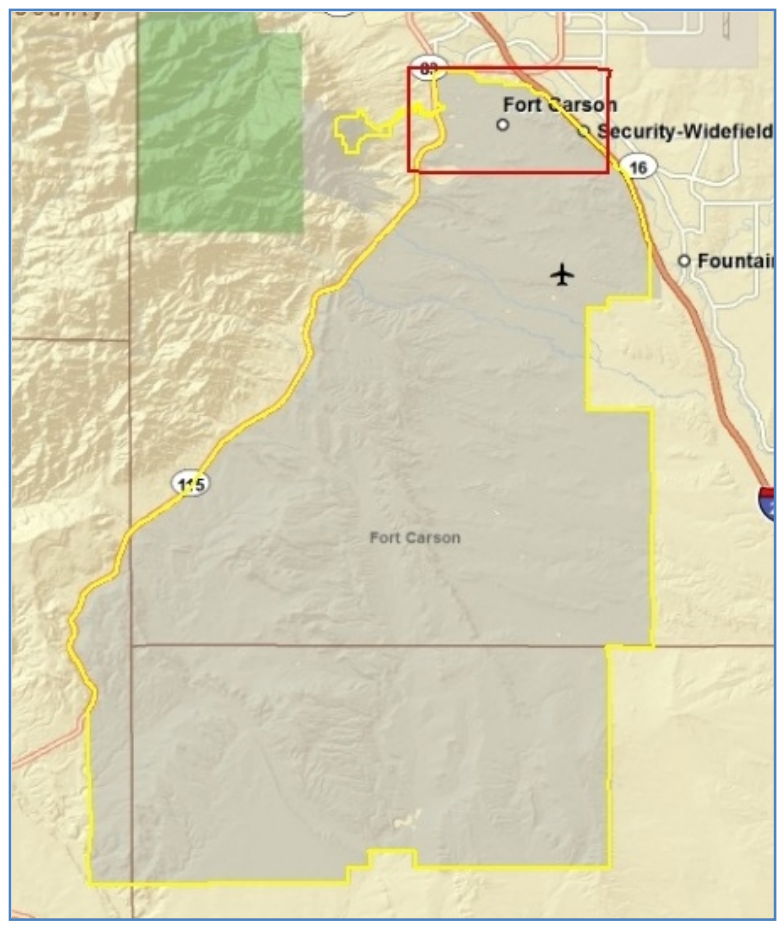

Figure 6. Boundary for Fort Carson energy baseline (Credit: Billy Roberts, NREL)

\subsection{Site versus Source Energy}

Many people are familiar with the terms site Btu or site energy, which refers to the amount of fuel and electricity consumed and reflected in utility bills. However, energy may be delivered to a facility as either primary or secondary energy. Primary energy is raw fuel that is burned on-site to create heat or electricity. Secondary energy is the product of the combustion of the raw fuel as thermal energy or electricity. It is not possible to directly compare primary with secondary energy because the former is a raw fuel and the latter is a product of combustion of the raw fuel.

Utilizing source energy as the common metric for analysis, as is done within this assessment, permits comparison of the primary and secondary energy, and also better supports assessment of 
DoD goals for fossil fuel reduction and renewable energy generation. A source energy analysis enables us to also account for the energy required to transport fuel to the base, as well as for energy losses due to inefficiencies in the electrical generation process.

For raw fuels, the difference between site and source energy is minimal. Source energy accounts for fuel distribution and dispensing, but not fuel production. For example, diesel fuel losses for fuel transport, storage, and dispensing are accounted for, but energy used in extracting crude oil and refining it into diesel fuel is not accounted for. The same basic analysis applies to electricity: losses in producing the fuel to be combusted for electrical energy production are not accounted for. However, the losses in the conversion of a primary chemical fuel, such as coal, to a secondary fuel, such as electricity, are accounted for.

The conversion factor to translate between site and source energy for a specific installation depends on many factors, such as the location of the installation, the efficiency of the energy distribution system, and the location from which the installation's energy is sourced. For example, the electrical energy conversion factor will depend on the specific power plant from which an installation receives its energy, the efficiency of the power plant, and the proximity to the installation. For this analysis we used a Colorado Springs Utilities (CSU) specific electrical site-to-source ratio and national ratios for natural gas, gasoline, and diesel fuel (see Table 6).We calculated the CSU ratio based on CSU's generation mix and source factors for each fuel type in the mix. Ratios were not available for E85 or compressed natural gas, so we used the gasoline ratio for $\mathrm{E} 85$ and the natural gas ratio for compressed natural gas.

\section{Table 6. Site-to-Source Energy Ratios ${ }^{4,5}$}

\begin{tabular}{|l|r|}
\hline Energy Type/Fuel & Site-to-Source Ratio \\
\hline Electricity & 2.798 \\
\hline Natural Gas & 1.092 \\
\hline Gasoline & 1.187 \\
\hline Diesel Fuel & 1.158 \\
\hline E85 & 1.187 \\
\hline Compressed Natural Gas & 1.092 \\
\hline
\end{tabular}

\subsection{Energy Baseline}

\subsubsection{Current Energy Use}

An energy baseline provides an analysis of current energy consumption on base, as well as a metric against which to measure progress. Table 7 shows baseline energy consumption for Fort Carson.

\footnotetext{
${ }^{4}$ Deru, M.; Torcellini, P. Source Energy and Emission Factors for Energy Use in Buildings. NREL/TP-550-38617. Golden, CO: National Renewable Energy Laboratory, June 2007. www.nrel.gov/docs/fy07osti/38617.pdf, Accessed June 2010.

${ }^{5}$ CSU Sources of Generation. www.csu.org/residential/services/electricity/item854.html. Accessed June 2010.
} 
Table 7. Fort Carson Energy Baseline

\begin{tabular}{|l|r|r|r|}
\hline \multirow{2}{*}{\begin{tabular}{l} 
Energy Source \\
\cline { 1 - 4 }
\end{tabular}} & $\begin{array}{r}\text { Site Energy } \\
\text { (Variable units) }\end{array}$ & $\begin{array}{r}\text { Site Energy } \\
\text { (MMBtu) }\end{array}$ & $\begin{array}{r}\text { Source Energy } \\
\text { (MMBtu) }\end{array}$ \\
\hline Buildings and Facilities & $164,406,919 \mathrm{kWh}$ & 560,956 & $1,569,556$ \\
\hline Electricity & $1,137,540 \mathrm{KCF}$ & 927,095 & $1,012,388$ \\
\hline Natural Gas & \multicolumn{4}{|c|}{ Fleet Fuel } & $1,488,052$ & $2,581,944$ \\
\hline Total Building Energy Use & 77,799 gallons & 8558 & 10,158 \\
\hline & 53,051 gallons & 7321 & 8478 \\
\hline Gasoline & 126,152 gallons & 11,089 & 13,163 \\
\hline Diesel & 19,497 gallons & 2435 & 2659 \\
\hline E85 & & 29,403 & 34,458 \\
\hline Compressed Natural Gas & Total & & \\
\hline Total Fleet Fuel Use & & $\mathbf{1 , 5 1 7 , 4 5 5}$ & $\mathbf{2 , 6 1 6 , 4 0 2}$ \\
\hline
\end{tabular}

The total baseline energy usage at Fort Carson is 1.5 million site MMBtu or 2.6 million source MMBtu per year. Electricity and natural gas account for most of this use, with a small portion going to fleet fuel, as Figure 7 shows.

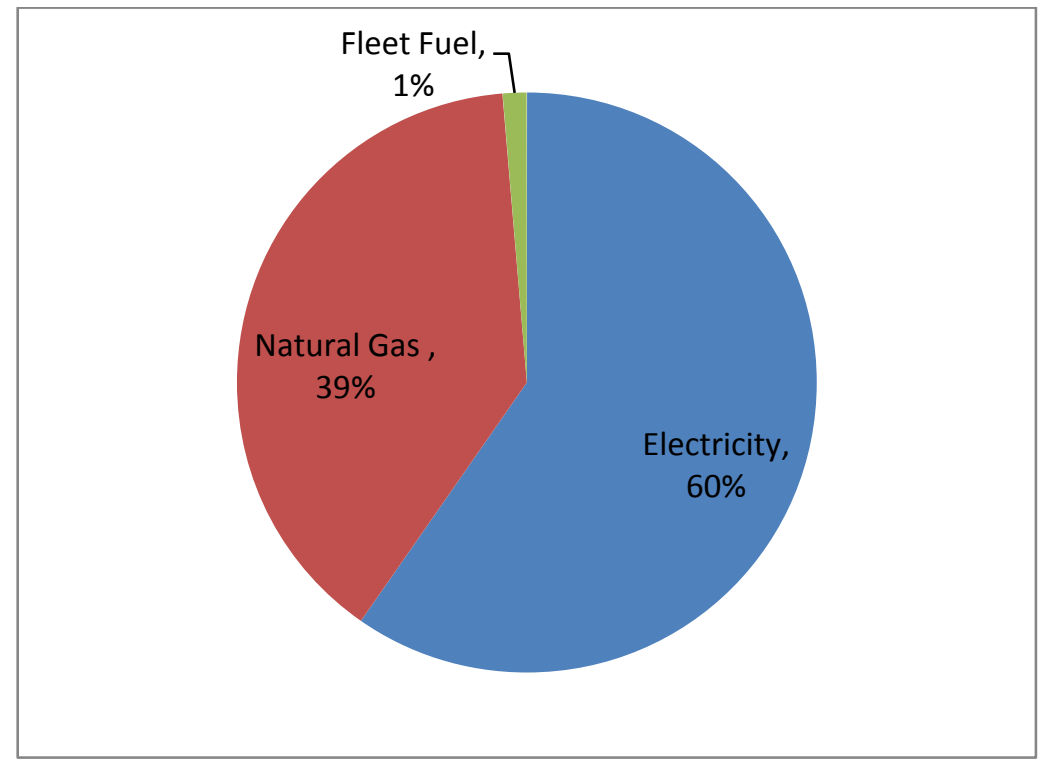

Figure 7. Fort Carson energy use breakdown (percentage of source total Btu) 


\subsubsection{Load Profile}

We based Fort Carson's load profile on 2009 monthly utility consumption and a typical load profile for a weekday and a weekend day in January (obtained from the base's recently installed advanced meters). Figure 8 shows the typical day load and Figure 9 depicts the annual load profile.

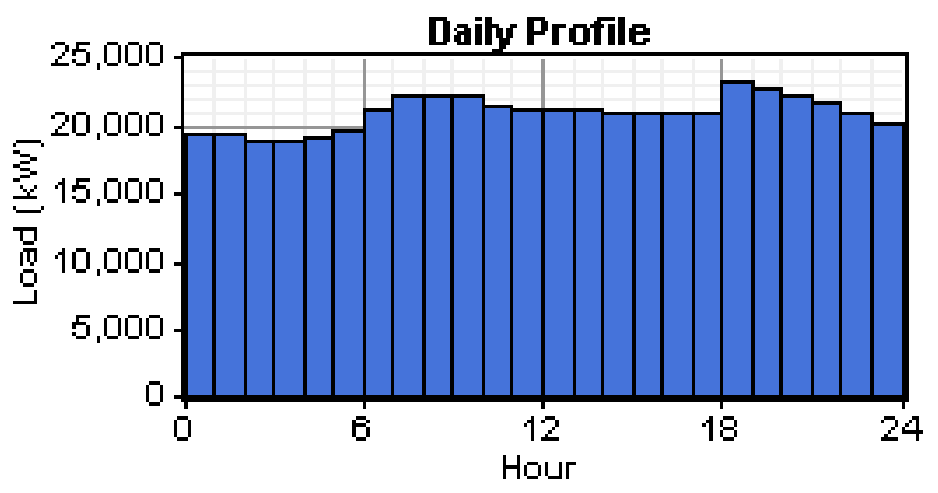

Figure 8. Typical daily load profile

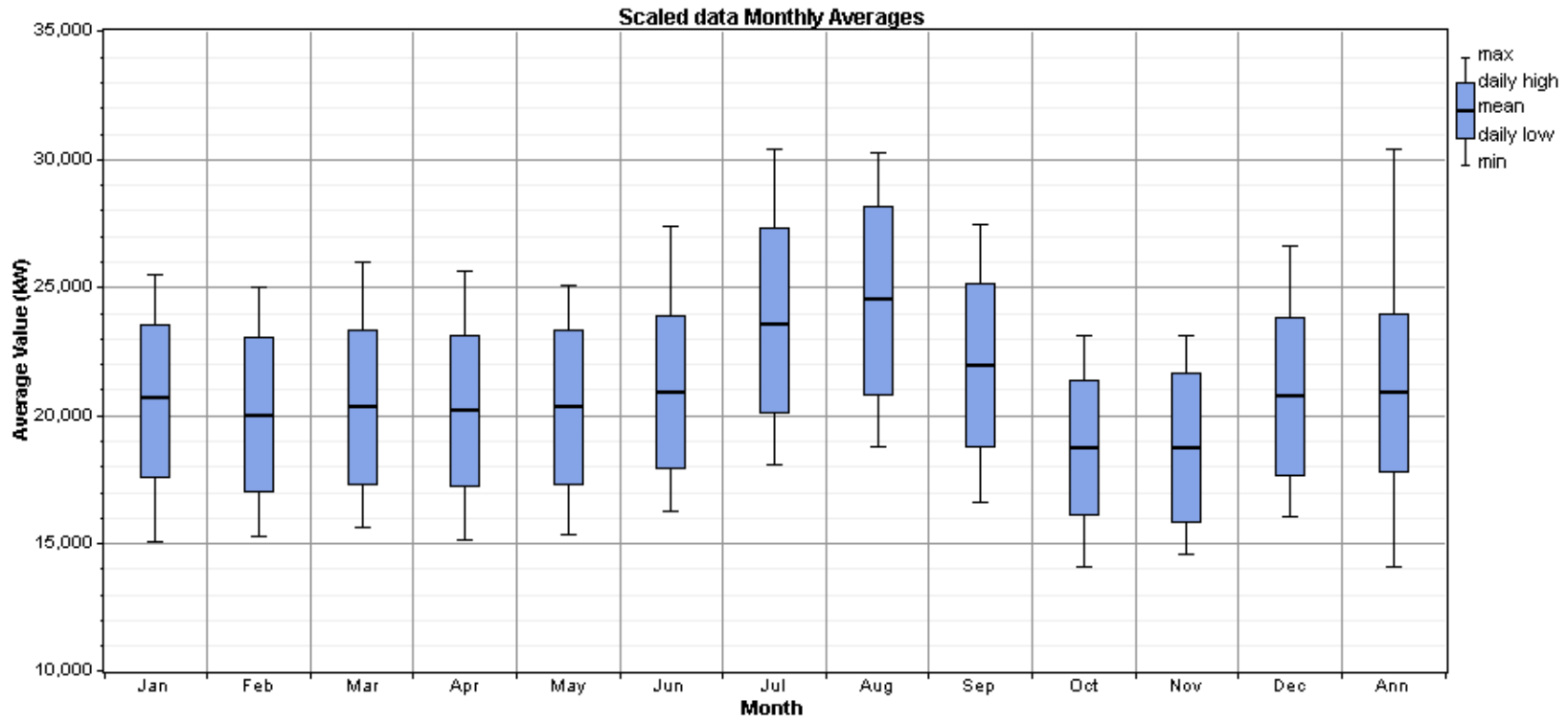

Figure 9. Annual load profile with 2 MW PV

The daily load profile shows two peaks (morning hours and evening hours). The dip in consumption during the middle of the day is partially due to the existing $2 \mathrm{MW}$ PV arrays, which reach peak power production at that time. The annual load profile shows an annual peak load of $28 \mathrm{MW}$.

\subsubsection{Projected Energy Use (2010-2015)}

Fort Carson expects to double its population from 15,000 to 30,000 by FY 2013 as other Army bases close and battalions are reassigned there. Fort Carson's building area is expected to grow 
$36 \%$ over the next five years to accommodate new personnel, leading to significant growth in energy use.

NREL predicted Fort Carson's energy growth based on the base's planned growth in total building area and the projected building energy use intensity (EUI). Figure 10 shows actual and projected EUI for 2003-2015, along with target values based on Federal mandates. The target EUI represents the EUI needed to meet Executive Order $13423^{6}$ and the Energy Independence and Security Act of 2007 (EISA) ${ }^{7}$ while the projected EUI was extrapolated from past EUI performance at Fort Carson. We base our prediction of future energy use on the projected EUI, which provides a more conservative estimate than target EUI, and we consider it a more realistic indicator of future performance.

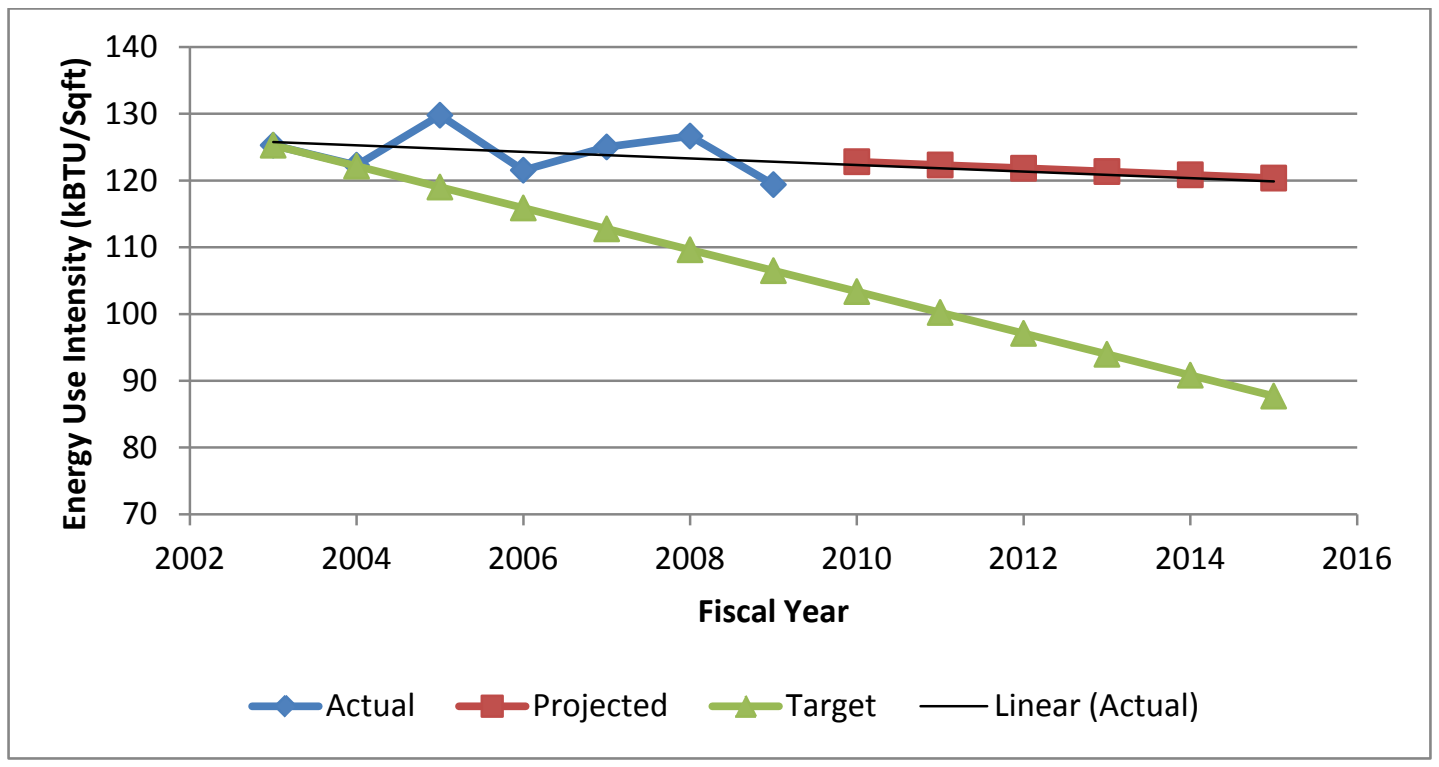

Figure 10. Fort Carson projected and target EUI (kBtu/ft $\left.{ }^{2}\right)$

Table 8 shows actual energy use in 2009 and projected energy use for 2010-2015. We assume that building energy use changes according to the projected building area and EUI, while energy use in privatized housing and Federal fleet remains constant. We predict site energy use will increase $27 \%$ from 2009 to 2015 , and source energy use will increase $33 \%$. The source energy increase is greater because electricity use increases more than natural gas, and electricity has a higher site-to-source ratio.

\footnotetext{
${ }^{6}$ Section 2a of Executive Order 13423 requires an energy intensity reduction of 3\% annually or a $30 \%$ combined reduction relative to a 2003 baseline. See http://edocket.access.gpo.gov/2007/pdf/07-374.pdf. Accessed June 2010. ${ }^{7}$ Section 431 of the Energy Independence and Security Act of 2007 requires that total energy use in Federal buildings, relative to the 2005 level, be reduced by $30 \%$ by 2015 . See http://energy.senate.gov/ public/_files/RL342941.pdf. Accessed June 2010.
} 
Table 8. Fort Carson Projected Energy Use, 2009-2015

\begin{tabular}{|c|c|c|c|c|c|c|c|}
\hline Year & FY09 & FY10 & FY11 & FY12 & FY13 & FY14 & FY15 \\
\hline $\begin{array}{l}\text { Military } \\
\text { Construction } \\
\text { Budget (\$ } \\
\text { millions) } \\
\end{array}$ & - & $\$ 493.10$ & $\$ 143.60$ & $\$ 59.70$ & $\$ 148.10$ & $\$ 75.00$ & $\$ 0$ \\
\hline $\begin{array}{l}\text { Estimated New } \\
\text { Building Area } \\
\text { (KSF)@ } \\
\$ 250 / \mathbf{f t}^{2}\end{array}$ & - & 1,972 & 574 & 239 & 592 & 300 & 0 \\
\hline $\begin{array}{l}\text { Estimated Total } \\
\text { Building Area } \\
\text { excluding } \\
\text { housing (KSF) } \\
\end{array}$ & 10,230 & 12,202 & 12,776 & 13,015 & 13,607 & 13,907 & 13,907 \\
\hline $\begin{array}{l}\text { Projected } \\
\text { Energy Use } \\
\text { Intensity } \\
\text { (KBTU/SF) } \\
\end{array}$ & 119.4 & 120.8 & 120.0 & 119.2 & 118.4 & 117.7 & 116.9 \\
\hline $\begin{array}{l}\text { Estimated } \\
\text { Family Housing } \\
\text { Area (KSF) } \\
\end{array}$ & 4,400 & 4,400 & 4,400 & 4,400 & 4,400 & 4,400 & 4,400 \\
\hline $\begin{array}{l}\text { Family Housing } \\
\text { Energy Use } \\
\text { Intensity } \\
\text { (KBTU/SF) }\end{array}$ & 61.3 & 61.3 & 61.3 & 61.3 & 61.3 & 61.3 & 61.3 \\
\hline $\begin{array}{l}\text { Fleet Fuel Site } \\
\text { Energy Use } \\
\text { (MMBtu) } \\
\end{array}$ & 29,403 & 29,403 & 29,403 & 29,403 & 29,403 & 29,403 & 29,403 \\
\hline $\begin{array}{l}\text { Projected Site } \\
\text { Energy } \\
\text { (MMBtu) }\end{array}$ & $1,517,455$ & $1,773,081$ & $1,832,199$ & $1,850,467$ & $1,910,148$ & $1,935,933$ & $1,924,807$ \\
\hline $\begin{array}{l}\text { Projected } \\
\text { Source Energy } \\
\text { (MMBtu) }\end{array}$ & $2,616,402$ & $3,067,785$ & $3,196,118$ & $3,255,107$ & $3,387,331$ & $3,461,326$ & $3,470,201$ \\
\hline
\end{tabular}

\subsection{Utility Costs}

FY 2009 electricity costs ranged from $\$ 0.0264-0.0313 / \mathrm{kWh}$ and the monthly demand charge varied from $\$ 11.36 / \mathrm{kW}-\$ 14.11 / \mathrm{kW}$. The blended rate averaged $\$ 0.05 / \mathrm{kWh}$. Figure 11 shows historical and projected electric rates. CSU is projecting rate increases of $12 \%$ per year for 20102016. If electric rates increase at the projected rate, prices will double from 2009's $\$ 0.05 / \mathrm{kWh}$ to $\$ 0.10 / \mathrm{kWh}$ in 2016 .

The cost of fossil energy is an important factor in determining the economic viability of investments in energy efficiency or renewable energy. This analysis uses CSU projections for 
electricity prices from 2010-2016, and a subsequent annual growth rate of $2.2 \%$ (1\% above inflation) for 2017-2035. For natural gas price growth rates, we assume a constant $2.2 \%$ annual growth rate for 2010-2035. The economics of projects could change significantly if utility prices change at a different rate.

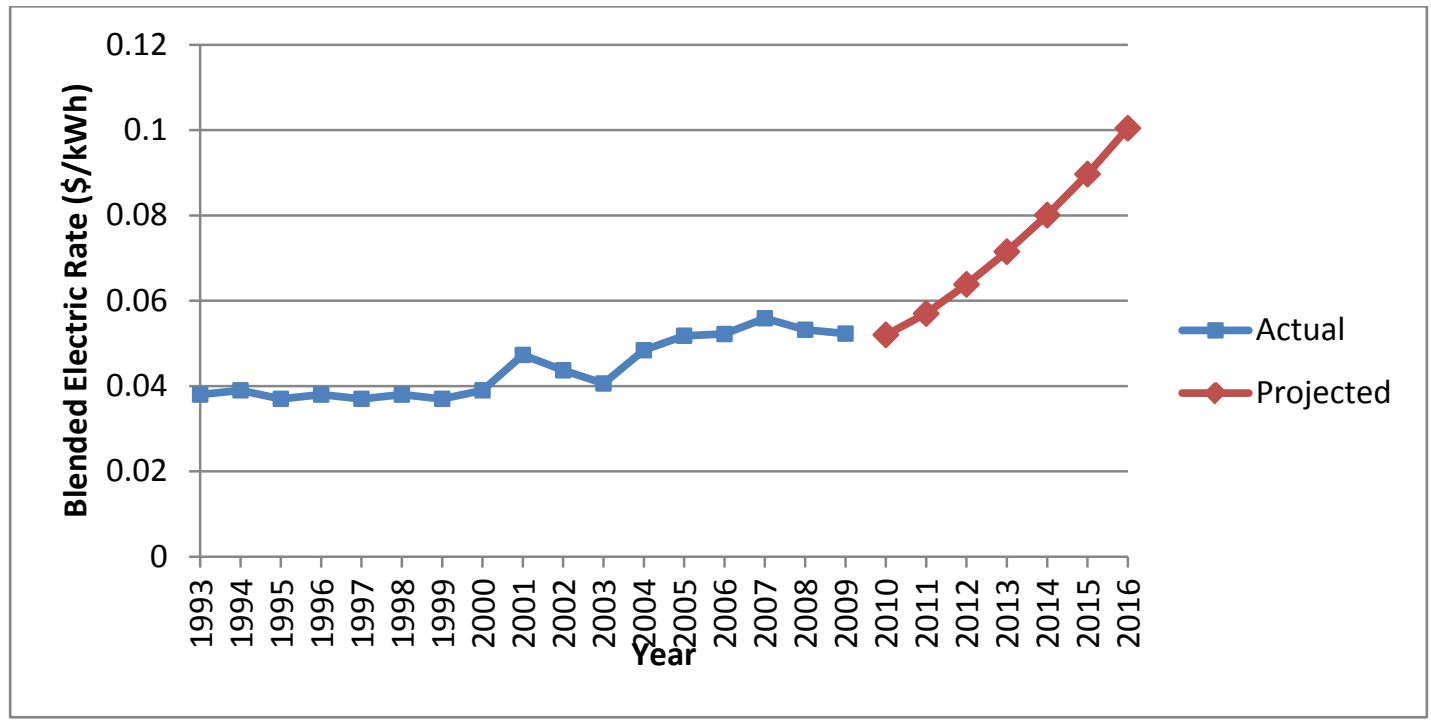

Figure 11. Actual and projected blended electric rates, 1993-2016

Figure 12 shows historical natural gas rates. Projected rates were not available, but 2009 rates were historically low, and Fort Carson expects natural gas rates to increase again in future years.

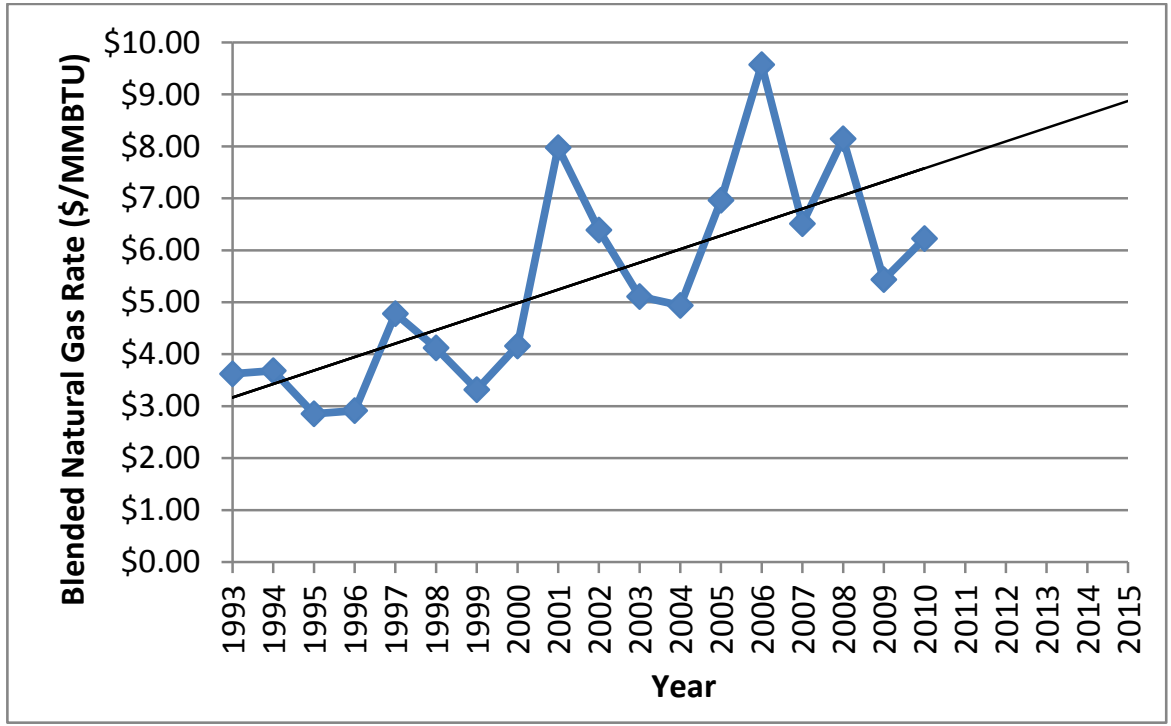

Figure 12. Actual natural gas rates, 1993-2010 


\subsection{Other Energy Uses}

While not included in the energy baseline, it is important to note that significant quantities of tactical fuel and commuter fuel are consumed on Fort Carson. Figure 13 shows that tactical fuel and commuter fuel use actually make up the majority of transportation fuel use.

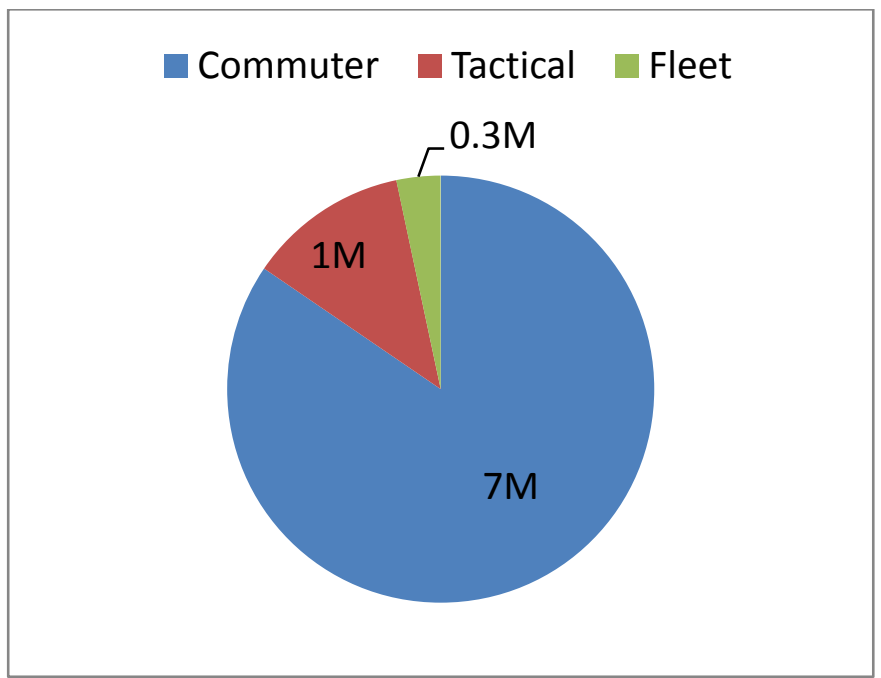

Figure 13. 2009 Fort Carson fuel use estimates by segment

The amounts of fuel used for tactical operations and by commuters are outside of the control of the installation energy managers. Although there are opportunities for future analysis in examining the potential to reduce the use of fuel in training operations and commuting vehicles, this project did not include these uses. In addition, NREL was not able to determine the footprint from commercial flights taken by base personnel; however, this is another area for energy use analysis. 


\section{Reducing Energy Demand by Engaging People}

Having established baseline energy use, analysts turned to the task of identifying the most economic ways to reduce the installation's energy demand. There are two main approaches: 1) identifying actions to reduce energy use without the need for capital expenditures, and 2) implementing energy-efficient technologies and design strategies. Identifying opportunities for procedural, behavioral, process, or operational energy-saving actions relies on engaging the attention and creativity of personnel, especially those with experience at the installation. Implementing energy-efficient technologies and design strategies is largely a technical exercise, which the next section will address.

Security, economic, and environmental objectives support a DoD-wide - and nationaltransition to clean energy that we may usefully view as culture change, requiring individual awareness of energy costs, new habits of energy use, and continuing creative attention to ways of reducing energy demand. There is no silver bullet or purely technological solution to our present energy challenges: even with the adoption of energy efficient technologies, there is a tendency for energy demand to increase with growing populations and the arrival of new generations of energy-using devices. So in conjunction with an NZEI analysis, DoD leaders should institutionalize ways of engaging peoples' ingenuity to reduce energy demand. This assessment does not attempt to quantify energy reductions due to behavior changes; however, the outline of a recommended approach follows.

- Assess potential demand reduction. Estimate potential energy demand reductions from personnel actions, changes to processes, improvements to mission execution, and other sources (provide estimates in energy units and dollars). Create dedicated teams in functional areas across the installation's operations to identify actions to permanently minimize energy use. Suggested actions should have a neutral effect on mission performance, or improve it. Consider energy use in facilities (lighting intensity, heating or air conditioning set points, and hours of operation), transport (vehicle miles, need for travel versus teleconferencing or videoconferencing), and mission uses (required hours of use of aircraft/ships/subs/ground vehicles for training and operations).

- Continuous improvement. Beyond the net zero energy assessment, Fort Carson can engage peoples' ingenuity in saving energy on a continuing basis:

- Institute an Energy Awareness campaign. Establish attention to energy use as a normal part of all activity, including planning, training, and mission execution.

- Create competitions/contests/incentives for new ideas, or for reduced energy use. Make it a point of pride to help increase national energy independence through reducing dependence on energy from imported and/or "dirty" sources.

- Create leadership/personnel teams to continue developing ways to save energy. Leading by example is a powerful influence across officer, enlisted, government, civilian, and contractor elements of the military team. 
○ Implement energy scoreboards. The scoreboards would assess energy usage by individuals, buildings, or organizations and recognize best performers and practices.

The Federal Energy Management Program has published several guides on how to conduct an energy awareness campaign:

\section{Creating an Energy Awareness Program}

http://www1.eere.energy.gov/femp/pdfs/yhtp ceap hndbk.pdf

Handbook from the Federal Energy Management Program on how to create an energy

awareness program and campaign.

\section{Promoting Behavior Based Energy Efficiency in Military Housing}

http://www1.eere.energy.gov/femp/pdfs/military hndbk.pdf

Handbook from the Federal Energy Management Program on promoting energy efficiency in military housing.

\section{Energy Managers Handbook}

http://www.wbdg.org/ccb/DOD/DOD4/dodemhb.pdf

Department of Defense Handbook for energy managers that provides tools to help facility and installation energy managers perform their jobs more effectively by answering questions and illustrating best practices. 


\section{Energy Efficiency Assessment}

\subsection{Overview}

After behavior change, energy efficiency is typically the most cost-effective energy project investment. Before conducting analysis of the renewable energy generation technologies at Fort Carson, we evaluated the potential for energy efficiency improvement, seeking ways to reduce the electrical and natural gas loads at the base.

Fort Carson has already planned several projects to increase the efficiency of its building portfolio. We conducted analyses on these planned energy efficiency projects as well as further energy efficiency improvement potential. Since building-level energy use information was not available, we evaluated the proposed energy efficiency measures on a high level, using very general base information. Therefore, planners should not consider these figures as investment grade calculations; nor should they use them to determine the economics of a potential investment. The recommendations should be used for planning only, and for the purpose of identifying energy conservation measures (ECMs) for further investigation.

It was beyond the scope of this project to conduct detailed energy audits of the approximately 800 installation facilities at Fort Carson. However through discussion with base personnel, analysis of the previous energy savings performance contracts (ESPC) proposals and energy assessments, and a walk-through of several of the facilities on base we were able to estimate the savings potential for energy efficiency investment at the base. Using energy models and spreadsheet calculation tools developed at NREL, we modeled $66 \%$ of the electrical load and $70 \%$ of the natural gas load and analyzed them for energy efficiency measures. It would be difficult to model the remaining energy use without an in-depth energy assessment, due to the distributed nature of the site and the specialty uses of various facilities.

Table 9 summarizes the savings estimates, which the following sections explain in more detail. We estimate $26.7 \%$ potential electricity savings, $17.2 \%$ natural gas savings, and $20.3 \%$ overall savings. 
Table 9. Project Savings Summary

\begin{tabular}{|c|c|c|c|c|c|}
\hline \multicolumn{2}{|l|}{ Measure } & \multicolumn{2}{|c|}{$\begin{array}{r}\text { Savings ( } \% \text { of } \\
\text { fuel type) }\end{array}$} & $\begin{array}{r}\text { MMBtu } \\
\text { Equivalent } \\
\text { Savings }\end{array}$ & $\begin{array}{r}\% \text { Total } \\
\text { Site } \\
\text { Savings }\end{array}$ \\
\hline \multirow{2}{*}{$\begin{array}{l}\text { DHW Boiler } \\
\text { Replacement }\end{array}$} & MWh & - & - & - & - \\
\hline & MMBtu & 10,704 & $0.9 \%$ & 10,704 & $0.6 \%$ \\
\hline \multirow{2}{*}{$\begin{array}{l}2009 \text { Energy } \\
\text { Assessment } \\
\text { Measures }{ }^{1}\end{array}$} & MWh & 3,378 & $2.1 \%$ & 11,529 & $0.7 \%$ \\
\hline & MMBtu & 39,743 & $3.5 \%$ & 39,743 & $2.3 \%$ \\
\hline \multirow[b]{2}{*}{ Privatized Housing } & MWh & 5,020 & $3.1 \%$ & 17,133 & $1.0 \%$ \\
\hline & MMBtu & 102,115 & $9.0 \%$ & 102,115 & $6.0 \%$ \\
\hline \multirow{2}{*}{$\begin{array}{l}\text { Central Heating } \\
\text { Plants }\end{array}$} & MWh & - & - & - & - \\
\hline & MMBtu & 43,225 & $3.8 \%$ & 43,225 & $2.5 \%$ \\
\hline \multicolumn{6}{|c|}{ Specific Main Base Facilities ${ }^{\mathrm{a}}$} \\
\hline $\begin{array}{l}\text { Retail }(28 \% \\
\text { reduction) }\end{array}$ & MWh & 371 & $0.2 \%$ & 1,266 & $0.1 \%$ \\
\hline $\begin{array}{l}\text { Barracks }(16 \% \\
\text { reduction) }\end{array}$ & MWh & 5,955 & $3.6 \%$ & 20,324 & $1.2 \%$ \\
\hline $\begin{array}{l}\text { Hospital }(38 \% \\
\text { reduction) }\end{array}$ & MWh & 6,420 & $3.9 \%$ & 21,911 & $1.3 \%$ \\
\hline $\begin{array}{l}\text { Commissary (31\% } \\
\text { reduction) }\end{array}$ & MWh & 1,439 & $0.9 \%$ & 4,911 & $0.3 \%$ \\
\hline $\begin{array}{l}\text { Headquarters (35\% } \\
\text { reduction) }\end{array}$ & MWh & 1,710 & $1.0 \%$ & 5,836 & $0.3 \%$ \\
\hline $\begin{array}{l}\text { Office }(35 \% \\
\text { reduction) }\end{array}$ & MWh & 1,311 & $0.8 \%$ & 4,474 & $0.3 \%$ \\
\hline $\begin{array}{l}\text { Other }(29 \% \\
\text { reduction) }\end{array}$ & MWh & 3,671 & $2.2 \%$ & 1,529 & $0.7 \%$ \\
\hline \multicolumn{6}{|c|}{ Base-Wide ECMs } \\
\hline Retro-commissioning & MWh & 8,220 & $5.0 \%$ & 28,055 & $1.7 \%$ \\
\hline $\begin{array}{l}\text { Computer Energy } \\
\text { Mgmt }\end{array}$ & MWh & 3,957 & $2.4 \%$ & 13,505 & $0.8 \%$ \\
\hline Occupancy Sensors & MWh & 2,173 & $1.3 \%$ & 7,416 & $0.4 \%$ \\
\hline \multicolumn{6}{|c|}{ Total } \\
\hline Electricity & MWh & 43,818 & $26.7 \%$ & 149,550 & $8.8 \%$ \\
\hline Natural Gas & MMBtu & 195,787 & $17.2 \%$ & 195,787 & $11.5 \%$ \\
\hline \multicolumn{4}{|l|}{ Total MMBtu } & 345,337 & $20.3 \%$ \\
\hline
\end{tabular}

a. We have reduced estimated savings for specific main base facilities, as indicated, to exclude heat plant measures. NREL re-evaluated heating plant savings and included the data separately. 


\subsection{Planned Efficiency Projects}

\subsubsection{DHW Boiler Replacement}

Fort Carson was recently awarded American Recovery and Reinvestment Act (ARRA) funding for a proposal to replace several of its hot water boilers throughout the base. The total projected savings are 10,704 MMBtu of natural gas, which represents $1 \%$ of the total baseline natural gas consumption of Fort Carson.

\subsubsection{Energy Assessment}

In August, 2009, the Energy Engineering Analysis Program (EEAP) conducted an energy assessment. The EEAP assessment contained a variety of energy savings opportunities and contained many advisable ECMs.

The potential energy savings from the 2009 EEAP report with the exclusion of central heating plant measures is 3,378 MWh/year electric and 39,743MMBtu/year natural gas. These figures represent $2 \%$ reduction in electrical usage and $3 \%$ reduction in natural gas usage, equivalent to just over a 3\% total site energy reduction. The central heating plant measures are evaluated separately in section 5.4 .

\subsection{Privatized Housing Opportunities}

There are approximately 3,060 housing units for members of the military and their families on the main base of Fort Carson. The houses were built over a 50 year period, and have substantial differences in construction, mechanical systems, occupancy, and resident behavior. In order to estimate the energy savings associated with the housing, NREL used a residential energy modeling program called BeOpt. ${ }^{8}$ With input from the housing contractor, we developed a model of a representative two-story, 1,600 square foot house.

BeOpt found the following energy efficiency improvements to be cost effective:

- Install programmable thermostats to save on heating and cooling

- Install low-flow faucets, shower heads, and toilets

- Decrease ventilation level

- Use seasonal natural ventilation

- Add insulation to the walls, attic, and slab

- Replace existing windows with high performance low-e windows

- Use interior shading to reduce cooling load in the summer

- Replace all lighting with florescent technology

- Replace current boiler with high efficiency boiler

- Replace current DHW heater with a gas tankless heater.

We calculated an $18 \%$ electricity reduction potential for the average-size housing unit. Applying this reduction potential to all of the housing units at Fort Carson equates to5,020,000 kWh/year.

\footnotetext{
${ }^{8}$ For more information on BeOpt, see: www.nrel.gov/buildings/energy_analysis.html\#beopt
} 
We calculated the natural gas reduction potential to be $45 \%$ for the average size housing unit. Applying this reduction to all of the housing units at Fort Carson equates to 102,115 MMBtu/year.

Other typical housing ECMs that could potentially be implemented, but were not investigated by the NREL team include:

- $\quad$ Switch out any non-ENERGY STAR ${ }^{\circledR}$ appliances

- Encourage residents to save energy with energy awareness campaign and incentives

- Reduce irrigation use

- Turn off the power and gas to unoccupied homes to eliminate standby losses.

\subsection{Central Energy Plant Opportunities}

The central heating plants generate steam and hot water to heat approximately $30 \%$ of the buildings on base. Energy use at the central plants represents $17.4 \%$ of the total base electrical load and $19.9 \%$ of the total base natural gas load.

Analysts developed an hourly simulation model in an effort to document and capture hourly seasonal effects with different potential heating plant measures in place. ECMs in the energy model include:

- Outdoor air-temperature-based seasonal HW temperature reset schedules

- Variable flow pumping

- Demand-based scheduling

- Reduced distribution losses.

The potential energy saving with the implementation of these measures in the central heating plants is $43,225 \mathrm{MMBtu} /$ year in natural gas, representing $7 \%$ of the plant and $3 \%$ of the total site energy.

Additional ECMs that could be implemented but were not investigated include:

- Central plant recommissioning

- Boiler stack economizers

- Central plant annual O\&M program to keep boilers running efficiently.

- Lighting measures.

\subsection{Main Base Facility Opportunities}

The main base facilities represent the vast majority of the energy use at Fort Carson, 74.7\% of the total electrical load and $30 \%$ of the total natural gas load. We developed recommendations to reduce energy usage in these facilities. Section 5.5.1 discusses energy conservation measures recommended for specific building types, and Section 5.5.2 discusses measures recommended base wide for all building types. 


\subsubsection{Conservation Measures by Building Type}

The NREL team evaluated several specific categories of buildings. These included:

- Offices

- Headquarters (HQ) buildings

- Commissary

- Hospital

- Barracks

- Retail space

- Other.

NREL spoke with the on-site staff about the base buildings, but did not visit the buildings. The team built basic energy models using typical building-type information and bundled ECMs to estimate the energy that could be saved in each building type. ECMs that we evaluated included:

- Chillers. Many of the current facilities at Fort Carson are operating moderately efficient chillers. We recommend all facilities be analyzed for more efficient chiller upgrades.

- Air Handling Units. According to the on-site staff, $70 \%$ of the air handling units (AHUs) at Fort Carson are constant volume (CV) systems and 30\% are variable air volume (VAV). Upgrading the CV units to VAV systems would save energy by reducing the amount of air to be either heated or cooled. We recommend the base evaluate its AHUs and upgrade units to VAV models where appropriate.

- Distributed Boilers. The efficiency of the boilers at Fort Carson varies. Some of the boilers are very efficient while, for others, replacement could save a substantial amount of energy. We recommend examination of the boilers not already scheduled for replacement in the retrofits funded by the American Reinvestment and Recovery Act (ARRA.) Technicians should examine boilers with efficiencies less than $85 \%$ for replacement potential with high efficiency boilers that can reach up to $95 \%$ efficiency. Factors to consider include expected time to replacement of existing boilers, as well as required supply and return water temperatures. Note that $95 \%$ efficiency systems are available with condensing boilers, but require low-return water temperatures that are not applicable for all applications.

- ENERGY STAR Refrigerators. Replacing refrigerators on the main base with Energy Star models could realize significant energy savings. It is assumed that small refrigerators are located in each of the barracks units and office buildings. Savings would vary by model being replaced, but would reach about 50-200 kWh per year for each refrigerator.

- Controls. According to on-site staff, 180 of the 800 buildings on the base have direct digital controls (DDC) and are connected to the central control system. There are plans to add an additional 27 buildings to the system using ARRA funds. All buildings that have HVAC systems should be added to the central DDC system. 
These actions will allow the implementation of base-wide set points and night time setbacks, as well as optimization of system operation. A central DDC system could potentially save a significant amount of energy. Some of the potential control upgrades follow:

○ Boiler optimization

○ Chiller optimization (chilled water reset and sequencing)

- Cooling tower optimization (recommendation to only run as many fans as needed to meet condenser water setpoint)

○ DDC controls

- Electric demand limiting

○ Static pressure setpoint

○ Mixed air dampers, for economizer

○ Night setback

○ Night purge (night pre-cooling of building)

○ Occupancy sensor control

○ Lighting scheduling (centralized lighting control)

○ Optimal start/stop HVAC systems

○ Outdoor air reduction

○ Supply air reset

- VAV and variable pumping.

- Hybrid Evaporative Cooling Roof Top Units. Many of the smaller buildings at Fort Carson are currently conditioned by standard roof top units. These units utilize a direct expansion (DX) refrigeration cycle to achieve cooling for the building. It is recommended that the site replace the standard DX roof top units with hybrid indirect evaporative cooling units. These units operate on a system that utilizes both evaporative cooling and the traditional refrigeration cycle. Indirect evaporative cooling is able to cool the space without adding any humidity to the conditioned air. Climate data show that Fort Carson is in a suitable location for hybrid evaporative cooling in its small commercial buildings. Tests performed at NREL demonstrate the potential for $75 \%$ savings in cooling energy when using this type of unit in place of a standard DX cooler. Fort Carson has many small commercial buildings, office buildings, and housing units that could be appropriate for this recommendation. These units work best in small- to medium-size buildings; therefore NRELs recommends that the larger facilities continue to utilize centralized chillers. The analysis for this ECM was performed based on products and technologies developed by the Coolerado Corporation.

The sections that follow describe the energy models for each specific building type along with the recommended ECMs. 


\section{Offices}

The main base at Fort Carson contains more than 644,000 sq. $\mathrm{ft}$ of office space. The average size of an office building is 8,157 square feet. Offices make up $5.7 \%$ of the total installation building square footage. Office space consumes an estimated 3,781 MWh per year of electrical energy or $2.3 \%$ of the total base usage. The offices do not consume any natural gas directly; however they receive heat from the central steam distribution line for heating. The NREL team created an eQuest energy model of the average office building to estimate the energy reduction potential of the offices at Fort Carson. Figure 14 shows the modeled energy use of the office buildings.

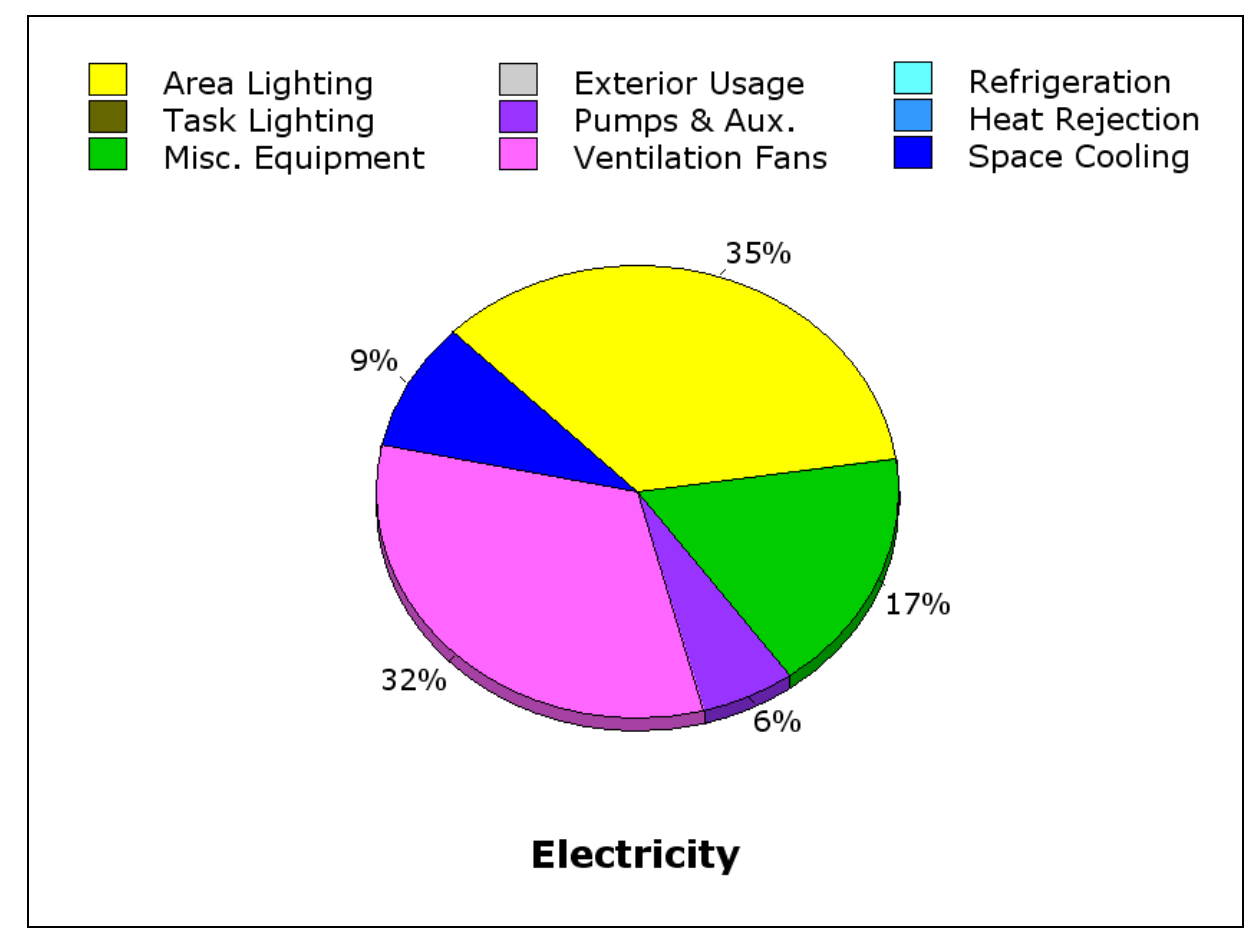

Figure 14. Modeled electricity end use for office buildings

NREL included the following ECMs in the energy model to estimate potential energy savings in the office buildings.

- Implement a nighttime and weekend setback on the HVAC system.

- Close the outside air dampers during unoccupied hours.

- Enable airside economizer operation.

- Replace the existing HVAC system with an indirect evaporative cooling system.

The energy reduction potential was calculated to be $35 \%$ for the average size office building, or $1,311,000 \mathrm{kWh} / \mathrm{yr}$ installation-wide.

There are additional office ECMs, which could potentially be implemented, however, the NREL team did not investigate them. These include: 
- Reduce lighting levels, use LED task lighting. Install occupancy sensors in most spaces.

- Replace all existing faucets and toilets with low flow devices.

- Put all offices on the central DDC system.

\section{HQ Buildings}

The main base of Fort Carson contains more than 1,926,000 sq. ft. of headquarters (HQ) buildings. The average building size is 12,588 square feet. HQ buildings make up $17 \%$ of the total square footage of installation buildings. The HQ space consumes an estimated 4,932 $\mathrm{MWh}$ per year of electrical energy, or 3.0\% of the total base usage. The HQ buildings do not consume any natural gas directly; however they do receive heat from the central steam distribution line for heating. Figure 15 shows the modeled energy use of the HQ buildings.

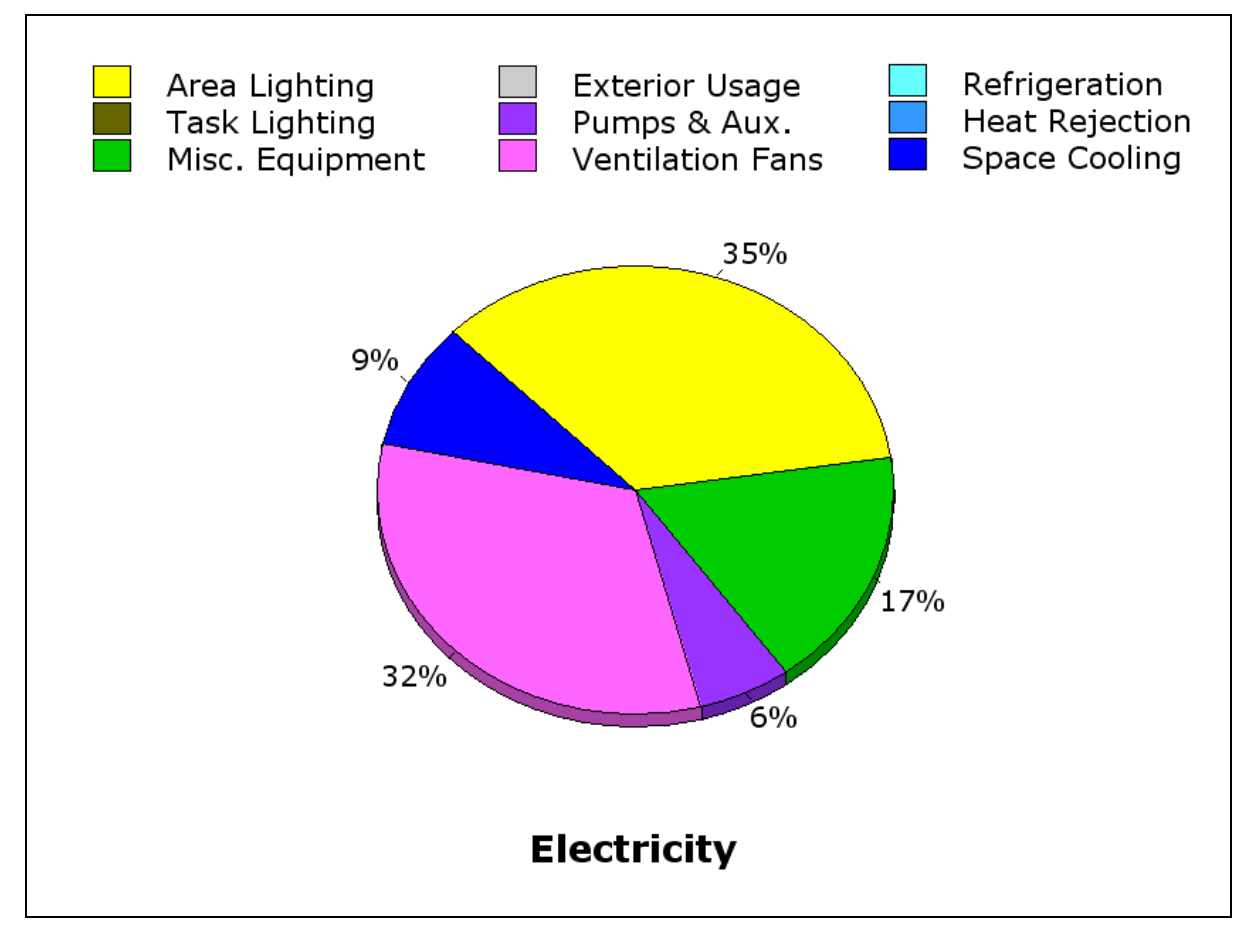

Figure 15. Modeled electricity end use for HQ buildings

The NREL team included the following ECMs in the energy model to estimate potential energy savings in the HQ buildings. Implement a nighttime and weekend setback on the HVAC system.

- Close the outside air dampers during unoccupied hours.

- Enable airside economizer operation.

- Replace the existing HVAC system with an indirect evaporative cooling system. 
We calculated the energy reduction potential to be $35 \%$ for the average size HQ building. Applying this reduction potential to all of the HQ buildings at Fort Carson equates to 1,710,000 $\mathrm{kWh} / \mathrm{yr}$.

There are additional ECMs, which could potentially be implemented, however, the NREL team did not investigate them. These include:

- Reduce lighting levels, use LED task lighting

- Install occupancy sensors in most spaces

- Replace all existing faucets and toilets with low-flow devices

- Put all HQ buildings on the central DDC system.

\section{Commissary}

The commissary is an on-base grocery store that provides goods and services to military personnel and their families. The commissary comprises $0.9 \%$ of the total installation building square footage. The commissary uses an estimated 4,603 MWh per year of electrical energy, or $2.8 \%$ of the total base usage. The commissary does not directly use any natural gas; however, it does receive heat from the central steam distribution line for heating. Figure 16 shows the modeled energy use of the commissary.

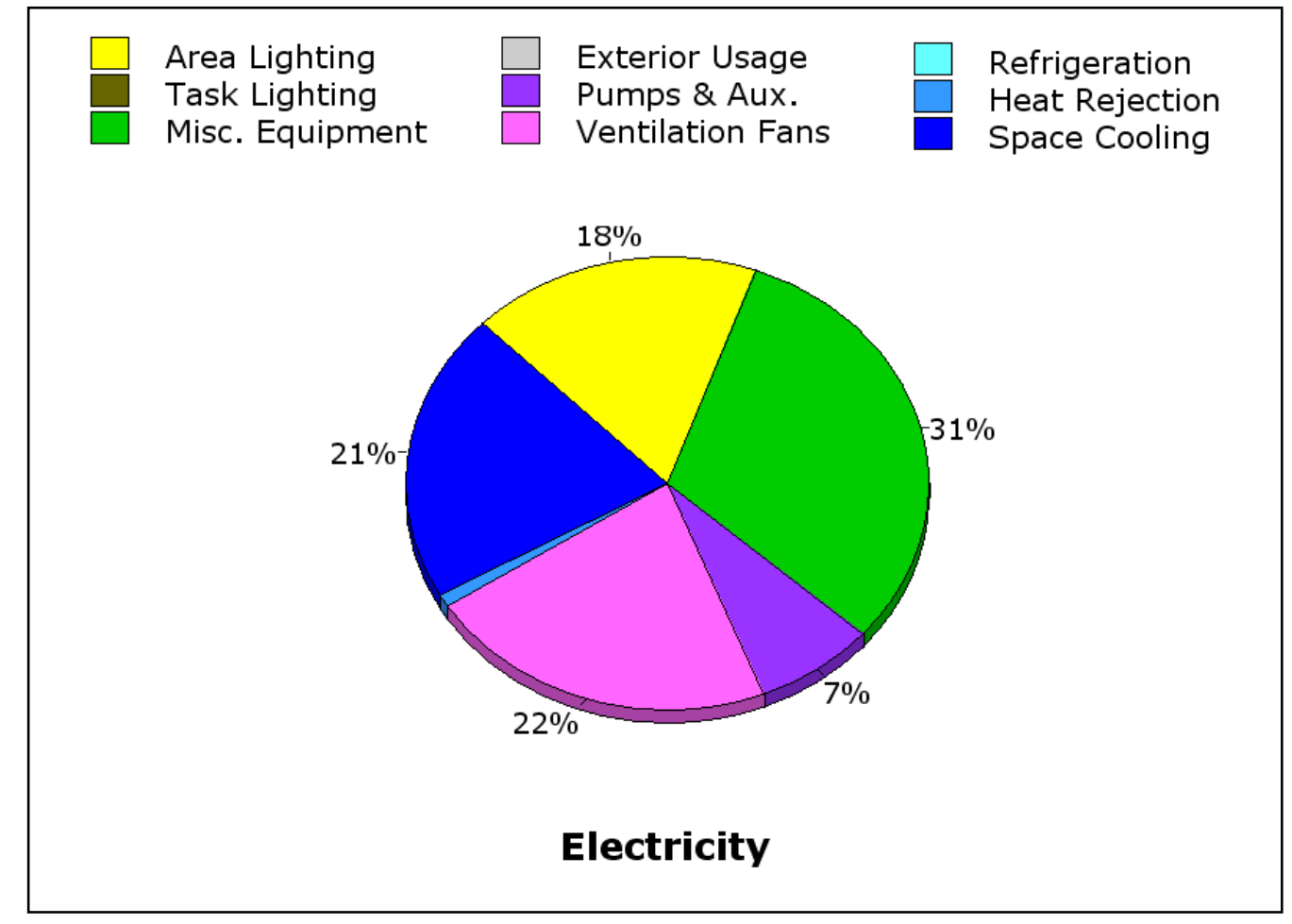

Figure 16. Modeled electricity end use for commissary 
Our analysis included the following ECMs in the energy model to estimate potential energy savings in the HQ buildings:

- Implement a nighttime and weekend setback on the HVAC system

- Close the outside air dampers during unoccupied hours

- Enable airside economizer operation

- Convert the system from a constant volume system to a VAV system

- Implement static pressure reset

- Replace the current chiller with a high efficiency variable speed chiller

- Put a variable frequency drive (VFD) on the cooling tower fan

- Implement a condenser water temperature reset

- Install chiller water temperature reset

- Put a VFD on the chilled water pumps.

Bundling these measures could provide the commissary with the potential to save $1,439,000$ $\mathrm{kWh}$, which would represent a $31 \%$ reduction in the electrical load of the commissary.

There are additional food sales ECMs that could potentially be implemented; however, the NREL team did not investigate them. These include:

- Lighting level reduction.

- Switching the light bulbs in freezers and refrigerators to LED bulbs to save on both cooling and lighting energy. The heat produced by standard bulbs increases energy requirements for the freezers by $25-50 \%{ }^{9}$

- Utilize waste heat from refrigeration to reduce its heating load requirements. (The heating load is estimated to comprise $15 \%$ of the energy use in an average food sales store.)

- Put the commissary on the central DDC system.

\section{Hospital}

The on-base hospital provides medical care to military personnel and their families. The hospital comprises $4.6 \%$ of the total installation building square footage. The hospital consumes an estimated $15,947 \mathrm{MWh}$ per year of electrical energy or $9.7 \%$ of the total base usage. Although the hospital does not consume any natural gas directly, it does receive heat from the central steam distribution line for heating. Figure 17 shows the modeled energy use of a hospital.

\footnotetext{
9 “Lighting The Way to Greener Retail", Nualight. www.nualight.ie/lighting the way to_greener_retail.pdf
} 


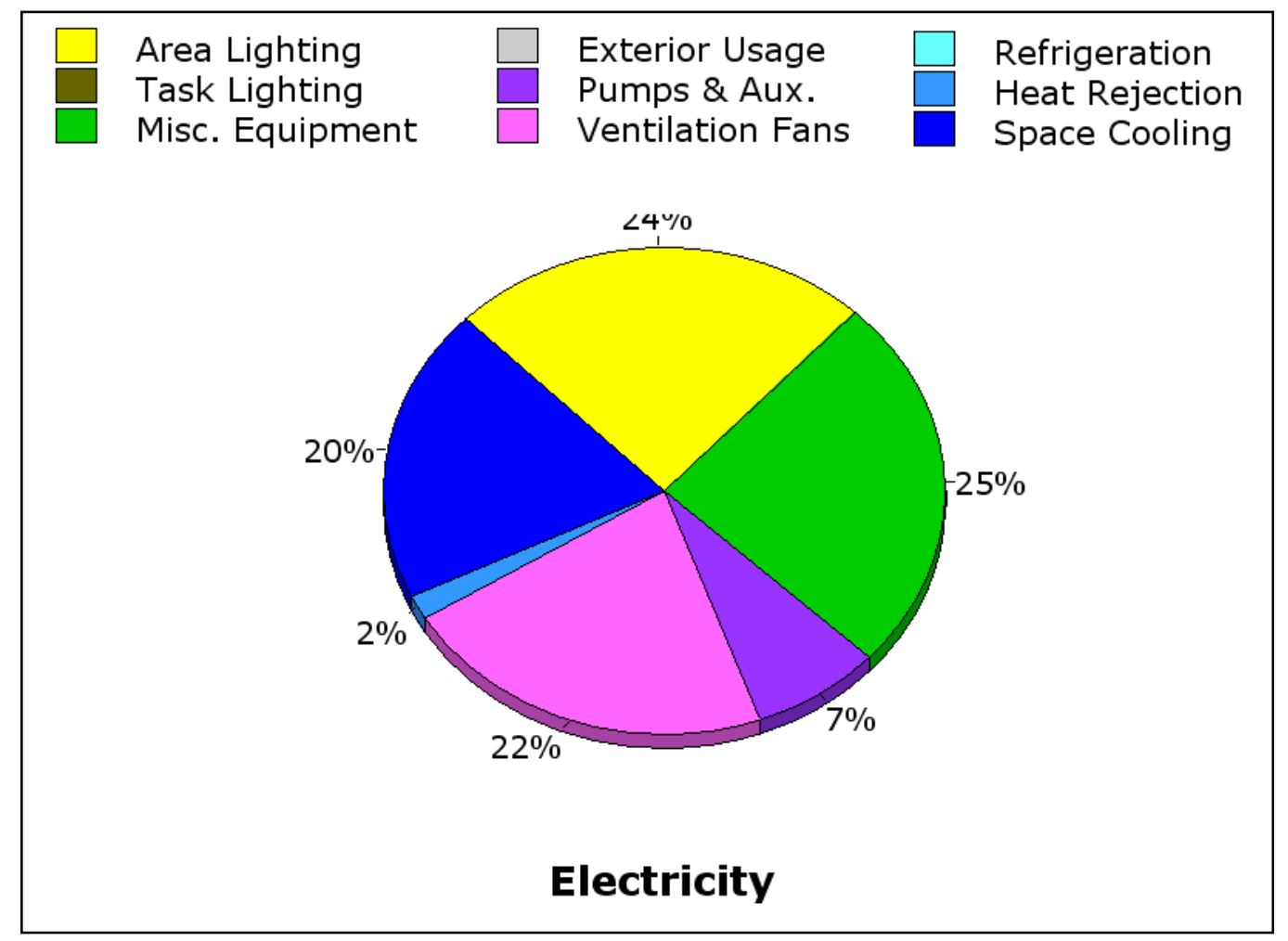

Figure 17. Modeled electricity end use for hospital

The NREL team included the following ECMs in its energy model to estimate the potential energy savings in the hospital:

- Set the OA to the minimum value during the night

- Enable airside economizer operation

- Convert the system from a constant volume system to a VAV system

- Implement duct static pressure reset

- Replace the current chiller with a high-efficiency variable speed chiller

- Put a VFD on the cooling tower fan

- Implement a condenser water temperature reset

- Install chiller water temperature reset

- Put a VFD on the chilled water pumps.

Bundling these measures, the hospital has the potential to save $6,420,000 \mathrm{kWh} /$ year, which represents a $38 \%$ reduction in the electrical load of the hospital.

Other typical hospital ECMs could be implemented; however, the NREL team did not investigate them. These include: 
- Lighting level reduction

- Occupancy sensors

- Replace all appliances with ENERGY STAR appliances

- Replace existing faucets, showers, and toilets with low-flow devices

- Utilize waste heat from the chillers to reduce the water heating and space heating load

- Put the hospital on the central DDC system.

\section{Barracks}

Fort Carson's barracks provide housing for the enlisted service members on the base. There are more than 3,253,000 square feet of barracks and similar housing at Fort Carson. The average building size is 35,361 square feet. Barracks and similar housing comprise $29 \%$ of the total installation building square footage. The barracks use an estimated 36,333 MWh per year of electrical energy or $22.1 \%$ of the total base usage. Although the barracks do not consume any natural gas directly, they do receive heat from the central steam distribution line for heating. Figure 18 shows a typical barracks building at Fort Carson, and Figure 19 shows the modeled energy use of the barracks.

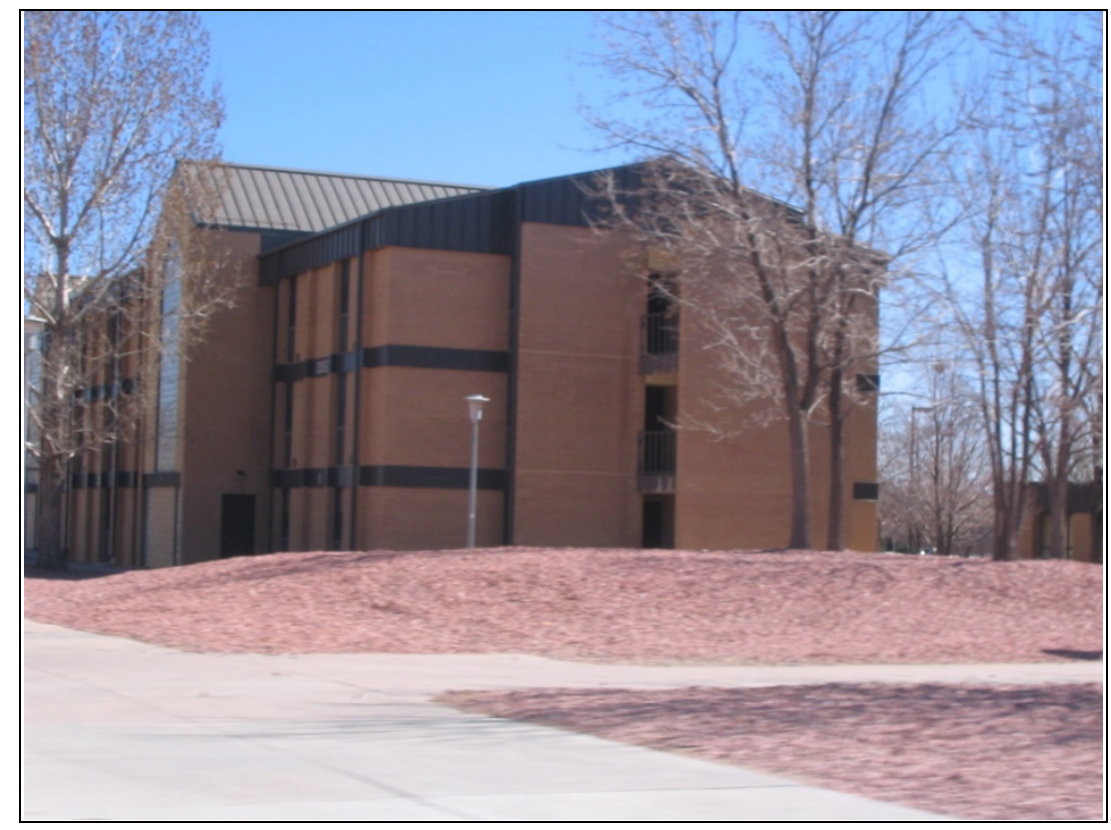

Figure 18. Fort Carson barracks (Credit: lan Metzger, NREL) 


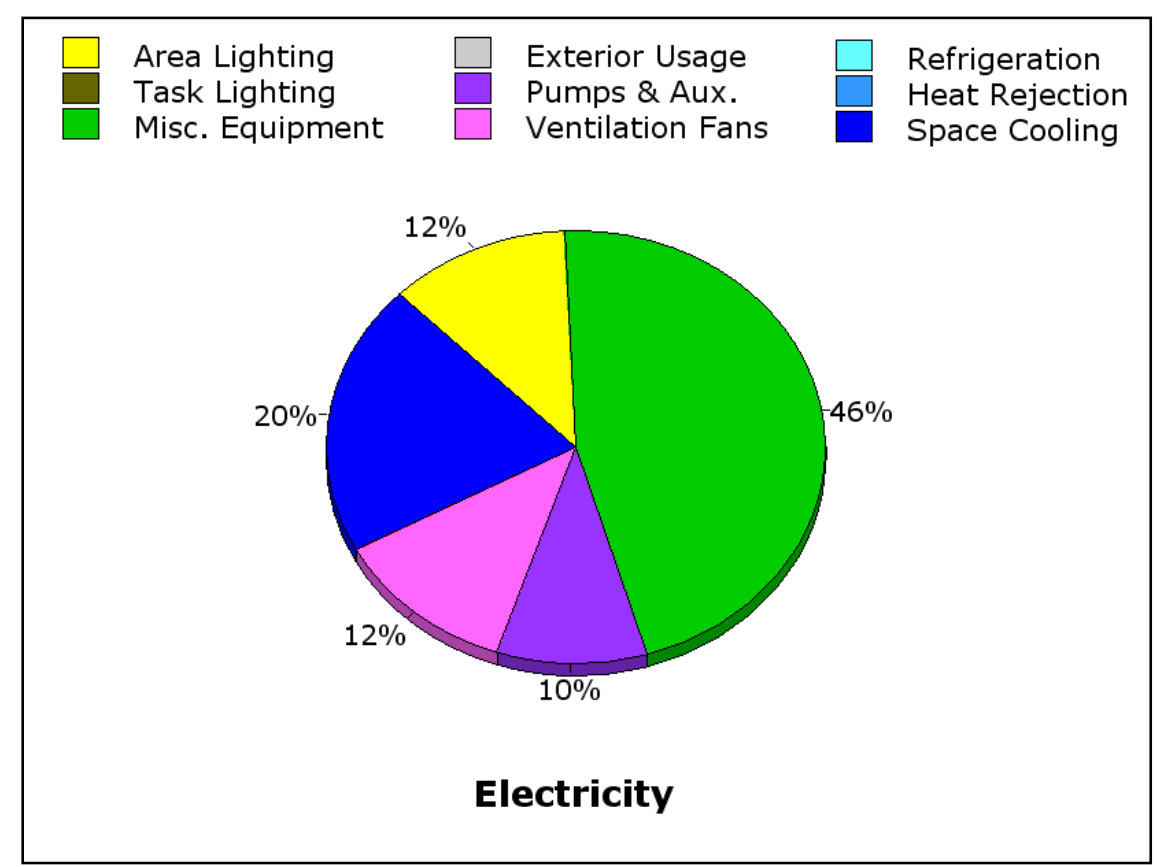

Figure 19. Modeled electricity end use for barracks

NREL included the following ECMs in the energy model in order to estimate the potential energy savings in the barracks:

- Replace the air cooled chiller with a high-efficiency water-cooled chiller

- Enable airside economizer operation

- Implement a variable flow chilled water system

- Reduce plug loads by implementing all ENERGY STAR appliances.

The analysis calculated an energy reduction potential of $16 \%$ for the average-size barrack. Applying this reduction potential to all of the barracks at Fort Carson equates to 5,955,000 $\mathrm{kWh} / \mathrm{yr}$.

Other ECMs potentially could be implemented in the barracks; however, the NREL team did not investigate them. These include:

- Replace washer and dryer with ENERGY STAR appliances

- Install low-flow faucets, showerheads, and toilets

- Install occupancy monitoring devices such as card readers to ensure that nonoccupied units are not being heated or cooled.

\section{Retail Space}

Retail space comprises $1.8 \%$ of the total installation building square footage. The on-base retail shops consume an estimated 1,315 MWh per year of electrical energy. Although the retail shops 
do not directly use any natural gas, some receive heat from the central steam distribution line for heating. The retail space represents $0.8 \%$ of total base electrical energy consumption. Figure 20 shows the modeled energy use of a retail store.

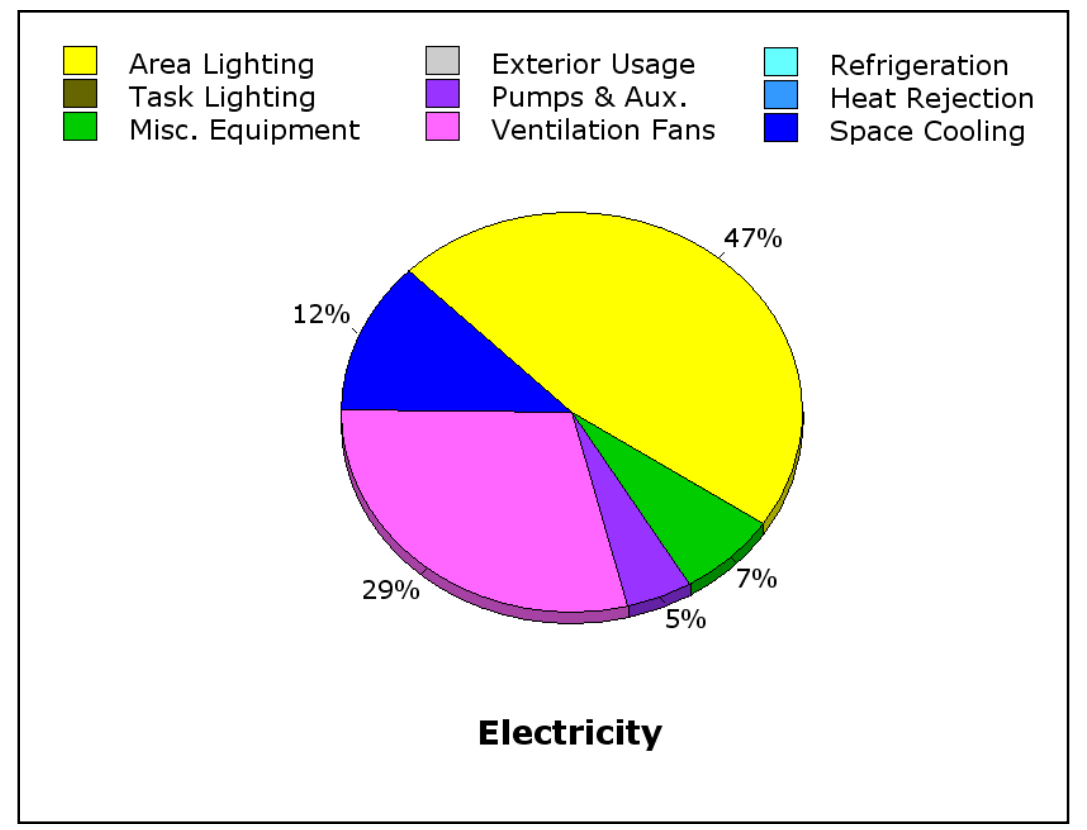

Figure 20. Modeled electricity end use for retail space

NREL included the following ECMs in the energy model to estimate the potential energy savings for the base's retail space:

- Implement a night time and weekend setback on the HVAC system

- Close the outside air dampers during unoccupied hours

- Enable airside economizer operation

- Replace the existing HVAC system with an indirect evaporative cooling system.

Bundling these measures, the base retail stores have the potential to save $371,000 \mathrm{kWh}$ year, which represents a $28 \%$ reduction in the electrical load.

Other retail store ECMs potentially could be implemented; however, the NREL team did not investigate them. These include:

- Reduce lighting levels

- Utilize lighting controls for nighttime and weekend setbacks

- Install occupancy sensors in the restrooms

- Install low-flow faucets and toilets. 


\section{Other Similar Building Types}

The structures grouped under other similar building types were those buildings that did not fit into any of our specific classifications. Nonetheless, they were similar enough to permit us to extrapolate the calculated savings from the specific building types and apply them to these other buildings, enabling us to include them in the analysis. The other similar building types consume an estimated $12,824 \mathrm{MWh}$ per year of electrical energy. This equates to $7.8 \%$ of total base electrical energy consumption. The extrapolation yielded the potential to save 3,761,000 $\mathrm{kWh} /$ year, which represents a $29 \%$ reduction in the building load.

\subsubsection{Base-Wide ECMs}

This section describes ECMs that apply base-wide, regardless of building type.

\section{Retro-Commissioning of All Mechanical Systems}

The assessment team recommends that the entire base be retro commissioned, building by building. Rather than replacing systems, retro commissioning involves going through all of the existing mechanical systems of a building, verifying operation and optimizing all functions. Commissioning can resolve operating problems, improve occupant comfort, and reduce energy use. The American Council for an Energy Efficient Economy estimated that retro commissioning could save $5-20 \%$ of building energy consumption. ${ }^{10}$

\section{Plug Loads}

NREL utilized its screening tools to estimate the potential for plug load reduction at Fort Carson. According to the on-site staff, most vending machines on the base had been retrofitted with ENERGY STAR vending machines. However, 105 five non-ENERGY STAR vending machines, however, continue to operate. These machines should be converted to ENERGY STAR models as the vending machine contracts come up for renegotiation. Additionally, base personnel stated that no computer power management programs were utilized. The assessment estimated the savings of measure including as installing vending machine misers, de-lamping 105 vending machines, and utilizing power management software on 8,000 computers $(4,000$ desktop, 4,000 laptop). Table 10 shows the projected savings from these measures. The majority of the savings come from the computer management program.

Table 10. Projected Savings of Several Energy Conservation Measures

\begin{tabular}{|c|c|c|}
\hline $\begin{array}{l}\text { Plug Load } \\
\text { ECM\# }\end{array}$ & Energy Conservation Measure & $\begin{array}{r}\text { Annual Energy } \\
\text { Savings (kWh/yr) }\end{array}$ \\
\hline 1.1 & Install Vending Machine Misers & 147,168 \\
\hline 1.2 & $\begin{array}{r}\text { De-Lamp Vending Machine } \\
\text { Advertising Lighting }\end{array}$ & 45,990 \\
\hline 1.3 & $\begin{array}{r}\text { Activate Computer Power } \\
\text { Management }\end{array}$ & $3,957,277$ \\
\hline \multicolumn{2}{|r|}{ Totals } & $4,150,435$ \\
\hline
\end{tabular}

\footnotetext{
${ }^{10}$ Thorne, J.; Nadel, S. "Retrocommissioning Program Strategies to Capture Energy Savings in Existing Buildings." American Council for an Energy Efficient Economy. June 2003. www.aceee.org/research-report/a035
} 
Install Occupancy Sensors in Office Spaces, Work Spaces, and Bathrooms

There are only a few working occupancy sensors currently installed in the office buildings at Fort Carson. Occupancy sensors can save considerable energy by turning off lights when spaces are unoccupied. Large cubicle workstation areas, conference rooms, private offices, and restrooms comprise the majority of the lighting load in a typical office building. It is likely that many of these areas are intermittently occupied or vacant throughout the course of the day, creating a potential for realizing energy savings by installing occupancy sensors.

We recommend installing ceiling-mounted infrared occupancy sensors to automatically activate and deactivate space lighting circuits based on occupancy. This measure will not reduce peak demand but will reduce annual energy consumption. This measure would result in an estimated energy savings of 2,172,802 kWh/yr. Our assumptions include:

- Lighting accounts for $20 \%$ of the total non-residential electric use for the buildings on site

- $80 \%$ of the lighting was appropriate for occupancy sensor control

- $10 \%$ of the lighting energy savings is due to occupancy sensors. ${ }^{11}$

\section{Exterior Lighting}

Upgrades to exterior lighting at the base have not been considered high priority at Fort Carson, due to the fact that the base pays a very low electrical rate at night. This circumstance makes exterior lighting projects difficult to justify based on cost savings alone. There are several exterior LED lighting demonstration units in use, but there is currently no plan to expand the LED exterior lighting fixtures. Therefore this report does not estimate savings from exterior lighting upgrades.

\footnotetext{
${ }^{11}$ American Society of Heating, Refrigerating, and Air Conditioning Engineers (ASHRAE) Standard 90.1
} 


\section{Renewable Energy and Additional Load Reduction Projects}

\subsection{Renewable Energy Project Recommendations}

After reducing energy use through conservation measures, renewable energy measures meet the remaining energy needs of an NZEI. Table 11 summarizes the renewable energy technologies analyzed, including evaluated size, potential energy savings, and simple payback period. Analysts based all payback periods on 2009 energy prices. The sections that follow present a detailed analysis of each technology.

Table 11. Renewable Energy Technologies: Potential Energy Savings and Payback Period

\begin{tabular}{|c|c|c|c|c|}
\hline Technology & Evaluated Size & $\begin{array}{r}\text { Potential } \\
\text { Site Energy } \\
\text { Savings } \\
\text { (MMBtu) }\end{array}$ & $\begin{array}{r}\text { Potential } \\
\text { Source } \\
\text { Energy } \\
\text { Savings } \\
\text { (MMBtu) }\end{array}$ & $\begin{array}{r}\text { Simple } \\
\text { Payback } \\
\text { Period } \\
\text { (years) }\end{array}$ \\
\hline $\begin{array}{l}\text { Solar Ventilation } \\
\text { Preheating } \\
\end{array}$ & $88,050 \mathrm{ft}^{2}$ & 26,353 & 28,777 & 15 \\
\hline Wind & $10.5 \mathrm{MW}$ & 61,304 & 171,528 & 16 \\
\hline Photovoltaics (PV) & $42.43 \mathrm{MW}$ & 216,178 & 604,865 & $26-46$ \\
\hline Biomass Heat Only & $30 \mathrm{MMBtu} / \mathrm{hr}$ & 160,000 & 174,720 & 29 \\
\hline $\begin{array}{l}\text { Solar Water } \\
\text { Heating } \\
\end{array}$ & $43,441 \mathrm{ft}^{2}$ & 20,887 & 22,809 & 30 \\
\hline $\begin{array}{l}\text { Concentrating } \\
\text { Solar Power (CSP) } \\
\end{array}$ & $10 \mathrm{MW}$ & 81,888 & 229,123 & 42 \\
\hline Fuel Cell & $1400 \mathrm{~kW}$ & $-8,000$ & 45,856 & 43 \\
\hline $\begin{array}{l}\text { Ground Source } \\
\text { Heat Pump } \\
\text { (GSHP) }\end{array}$ & 18,150 tons & 378,391 & 178,463 & 57 \\
\hline Daylighting & $770,000 \mathrm{ft}^{2}$ & 35,053 & 38,278 & 147 \\
\hline Biomass CHP & $\begin{array}{l}5 \mathrm{MW} \text { thermal, } \\
7 \mathrm{MW} \text { electrical }\end{array}$ & 283,771 & 452,792 & Negative \\
\hline Microturbine & $60 \mathrm{~kW}$ & $-1,428$ & 389 & Negative \\
\hline $\begin{array}{l}\text { Waste-to-Energy } \\
\text { (WTE) }\end{array}$ & $670 \mathrm{~kW}$ & 15,333 & 42,902 & Negative \\
\hline Landfill Gas & 0 & 0 & 0 & N/A \\
\hline $\begin{array}{l}\text { Anaerobic } \\
\text { Digestion }\end{array}$ & 0 & 0 & 0 & N/A \\
\hline Hydro Power & 0 & 0 & 0 & N/A \\
\hline
\end{tabular}




\subsection{Solar Ventilation Preheating}

\subsubsection{Technology Overview}

Solar ventilation air preheating is a very simple, yet efficient technology. The system consists of metal siding perforated with small holes, mounted on the south side of a building. The sun heats the metal plate and that heat is added to ventilation air drawn through the holes by means of a fan. In summer, a by-pass damper on the face of the wall admits fresh air without heating. Savings at the site depend on both the solar resource and the heating degree days. Solar vent preheat works very well in the Front Range's cold, sunny climate on buildings with large ventilation requirements. It is most often used on industrial buildings with open indoor spaces (not highly partitioned) and high ventilation requirements, including hangars, maintenance shops, and gymnasiums.

\subsubsection{Existing or Planned Projects}

Fort Carson currently has solar walls installed on two vehicle maintenance buildings (8030 and 9633), as Figure 21 shows.

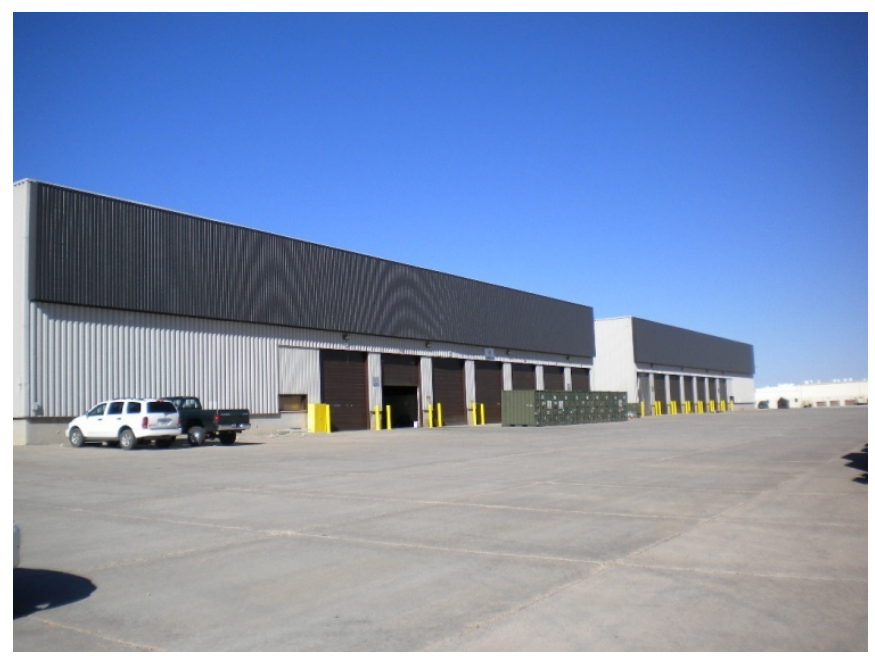

Figure 21. Fort Carson solar walls (Courtesy of Fort Carson)

\subsubsection{Analysis}

Table 12 identifies additional opportunities for solar ventilation preheating. The identified buildings appear to be good candidates based on building orientation and building type. 
Table 12. Potential Candidates for Solar Ventilation Preheating Systems

\begin{tabular}{|c|c|c|c|c|}
\hline $\begin{array}{l}\text { Building } \\
\text { Number } \\
\end{array}$ & Building Type & $\begin{array}{l}\text { Building } \\
\text { Size }\left(\mathrm{ft}^{2}\right) \\
\end{array}$ & $\begin{array}{r}\text { Estimated SVP } \\
\text { size }\left(\mathrm{ft}^{2}\right) \\
\end{array}$ & $\begin{array}{r}\text { Annual Heating } \\
\text { Savings (MMBtu/yr) }\end{array}$ \\
\hline 9604 & AC MAINT HGR & 41,062 & 3,647 & 1,092 \\
\hline 9604 & AC MAINT HGR & 44,281 & 3,788 & 1,134 \\
\hline 9604 & AC MAINT HGR & 13,671 & 2,105 & 630 \\
\hline 9604 & AC MAINT HGR & 1,626 & 726 & 217 \\
\hline 9604 & AC MAINT HGR & 1,635 & 728 & 218 \\
\hline 9620 & AC MAINT HGR & 41,476 & 3,666 & 1,097 \\
\hline 8110 & ARNG VEH MAINT & 26,340 & 2,921 & 874 \\
\hline 2427 & AUTO SKILL CTR & 29,531 & 3,093 & 926 \\
\hline 1525 & COMMISSARY & 101,725 & 5,741 & 1,718 \\
\hline 500 & FIRE STATION & 4,660 & 1,229 & 368 \\
\hline 9600 & FIRE STATION & 3,885 & 1,122 & 336 \\
\hline 1805 & MAIN FIRE STATION & 17,000 & 2,347 & 702 \\
\hline 749 & MNT GEN PURPOSE & 19,536 & 2,516 & 753 \\
\hline 2031 & MNT GEN PURPOSE & 2,500 & 900 & 269 \\
\hline 8000 & MNT GEN PURPOSE & 184,344 & 7,728 & 2,313 \\
\hline 8009 & PAINT/PREP SHOP, VEH & 2,500 & 900 & 269 \\
\hline 9271 & PHY FITNESS CENTER & 2,000 & 805 & 241 \\
\hline 1160 & PHYS FIT CTR & 20,375 & 2,569 & 769 \\
\hline 1661 & PHYS FIT CTR & 13,280 & 2,074 & 621 \\
\hline 1662 & PHYS FIT CTR & 2,715 & 938 & 281 \\
\hline 1662 & PHYS FIT CTR & 3,371 & 1,045 & 313 \\
\hline 1843 & PHYS FIT CTR & 17,502 & 2,381 & 713 \\
\hline 1856 & PHYS FIT CTR & 23,159 & 2,739 & 820 \\
\hline 2357 & PHYS FIT CTR & 24,895 & 2,840 & 850 \\
\hline 1829 & RECREATION CTR & 24,626 & 2,825 & 845 \\
\hline 9655 & TUAV HANGAR & 3,876 & 1,121 & 335 \\
\hline 7470 & TUAV HANGER & 4,800 & 1,247 & 373 \\
\hline 8930 & USAR VEH MAINT & 11,988 & 1,971 & 590 \\
\hline 501 & VEH MAINT SHOP & 34,877 & 3,362 & 1,006 \\
\hline 633 & VEH MAINT SHOP & 4,806 & 1,248 & 373 \\
\hline 633 & VEH MAINT SHOP & 2,406 & 883 & 264 \\
\hline 634 & VEH MAINT SHOP & 4,812 & 1,249 & 374 \\
\hline 635 & VEH MAINT SHOP & 4,812 & 1,249 & 374 \\
\hline 636 & VEH MAINT SHOP & 4,812 & 1,249 & 374 \\
\hline 746 & VEH MAINT SHOP & 5,040 & 1,278 & 382 \\
\hline 1382 & VEH MAINT SHOP & 23,575 & 2,764 & 827 \\
\hline
\end{tabular}




\begin{tabular}{|c|c|c|c|c|}
\hline 1392 & VEH MAINT SHOP & 23,575 & 2,764 & 827 \\
\hline 1682 & VEH MAINT SHOP & 27,175 & 2,967 & 888 \\
\hline 1692 & VEH MAINT SHOP & 23,575 & 2,764 & 827 \\
\hline 1882 & VEH MAINT SHOP & 21,935 & 2,666 & 798 \\
\hline 1982 & VEH MAINT SHOP & 15,470 & 2,239 & 670 \\
\hline 2082 & VEH MAINT SHOP & 23,703 & 2,771 & 829 \\
\hline 2392 & VEH MAINT SHOP & 23,575 & 2,764 & 827 \\
\hline 2492 & VEH MAINT SHOP & 23,575 & 2,764 & 827 \\
\hline 2605 & VEH MAINT SHOP & 51,617 & 4,089 & 1,224 \\
\hline 2615 & VEH MAINT SHOP & 51,617 & 4,089 & 1,224 \\
\hline 2625 & VEH MAINT SHOP & 51,617 & 4,089 & 1,224 \\
\hline 2635 & VEH MAINT SHOP & 51,617 & 4,089 & 1,224 \\
\hline 2645 & VEH MAINT SHOP & 51,617 & 4,089 & 1,224 \\
\hline 2655 & VEH MAINT SHOP & 51,617 & 4,089 & 1,224 \\
\hline 2692 & VEH MAINT SHOP & 23,575 & 2,764 & 827 \\
\hline 2792 & VEH MAINT SHOP & 23,575 & 2,764 & 827 \\
\hline 2992 & VEH MAINT SHOP & 23,575 & 2,764 & 827 \\
\hline 3092 & VEH MAINT SHOP & 23,575 & 2,764 & 827 \\
\hline 3192 & VEH MAINT SHOP & 23,575 & 2,764 & 827 \\
\hline 3292 & VEH MAINT SHOP & 23,575 & 2,764 & 827 \\
\hline 7426 & VEH MAINT SHOP & 16,386 & 2,304 & 690 \\
\hline 7467 & VEH MAINT SHOP & 34,306 & 3,334 & 998 \\
\hline 8030 & VEH MAINT SHOP & 50,750 & 4,055 & 1,214 \\
\hline 8142 & VEH MAINT SHOP & 45,200 & 3,827 & 1,145 \\
\hline 8152 & VEH MAINT SHOP & 23,298 & 2,747 & 822 \\
\hline 8200 & VEH MAINT SHOP & 16,881 & 2,339 & 700 \\
\hline 8300 & VEH MAINT SHOP & 15,715 & 2,256 & 675 \\
\hline 8300 & VEH MAINT SHOP & 650 & 459 & 137 \\
\hline 8300 & VEH MAINT SHOP & 24,490 & 2,817 & 843 \\
\hline 9072 & VEH MAINT SHOP & 28,362 & 3,031 & 907 \\
\hline 9277 & VEH MAINT SHOP & 4,000 & 1,138 & 341 \\
\hline 9277 & VEH MAINT SHOP & 4,000 & 1,138 & 341 \\
\hline 9628 & VEH MAINT SHOP & 12,737 & 2,031 & 608 \\
\hline 9628 & VEH MAINT SHOP & 8,934 & 1,701 & 509 \\
\hline 20001 & VEH MAINT SHOP & 3,811 & 1,111 & 333 \\
\hline Total & & & 176,100 & $\mathbf{5 2 , 7 0 7}$ \\
\hline
\end{tabular}


For the net zero analysis, we assume that half of these installations will be viable sites, resulting in a total of 88,050 square feet of solar ventilation preheat area and 26,353 MMBtu of annual energy savings.

\subsubsection{Economic Analysis}

Table 13 estimates the costs of installing solar ventilation preheating systems on these buildings.

Table 13. Solar Ventilation Preheating Financial Estimate

\begin{tabular}{|l|r|}
\hline Solar Vent Preheat Area $\left(\mathrm{ft}^{2}\right)$ & $\mathbf{8 8 , 0 5 0}$ \\
\hline Initial Cost (\$) & $\mathbf{\$ 2 , 2 4 1 , 2 7 7}$ \\
\hline Rebates \& Incentives & 0 \\
\hline Annual Gas Savings (MMIBtu/yr) & 26,353 \\
\hline Annual Utility Cost Savings (\$/yr) & $\$ 145,857$ \\
\hline Payback Period (yr) & 15.4 \\
\hline
\end{tabular}

\subsubsection{Recommendation}

Solar ventilation preheating systems are one of the most cost-effective renewable energy technologies available to Fort Carson. We recommend installing additional solar ventilation preheating systems wherever feasible, putting a priority on motor pools, hangars, and heat plant.

\subsection{Wind}

\subsubsection{Technology Overview}

Wind turbines consist of rotating blades that convert the momentum of the wind to electric power. They contain several moving parts and require regularly scheduled and unscheduled maintenance. Turbines range from as small as $250 \mathrm{~W}$ to as large as $5 \mathrm{MW}$. The larger wind turbines are the most economical. Wind turbines work best when installed in areas of wide open space. As a rule of thumb, a wind turbine requires 60 acres of land per megawatt. In the majority of cases, the presence of the turbine does not preclude using the land for other purposes, for example, agricultural activities.

\subsubsection{Planned or Existing Projects}

Fort Carson explored an on-site wind project with GE, but determined that the energy price was too costly. Fort Carson personnel are currently pursuing an option to buy off-site wind power at \$0.06-0.07/kWh through CSU from a wind farm in southern Colorado's Baca County.

\subsubsection{Analysis}

Fort Carson has a good wind resource in the southeast corner of the installation, about 20 miles south of the main base buildings. NREL measured the wind resource on site at Fort Carson from January 2008 to October 2009, using a 50m meteorological tower. In addition, we deployed a sonic detection and ranging (SODAR) unit between March and September 2008. Extrapolating from the measured data from the 50 meter tower, we estimate a resource of $6.8 \mathrm{~m} / \mathrm{s}$ at $80 \mathrm{~m}$. This estimate agrees with the NREL-validated wind map estimates of $6.5-7 \mathrm{~m} / \mathrm{s}$ at the meteorological tower site. Based on this resource, we estimate that a GE 1.5SLE turbine on an 80 meter tower 
would produce $2,557,215 \mathrm{kWh}$ per year (assuming losses of $11.5 \%$ ). This equates to a with a $19.5 \%$ capacity factor.

The map in Figure 22 shows the meteorological tower location (N38 26.001, W $\left.104^{\circ} 44.372\right)$. The site will accommodate 6-8 wind turbines the size of a GE 1.5 SLE and has good access to Fort Carson's 12/470 distribution line. The number of turbines is limited by available area on the ridgeline (where the best wind resource is) and Fort Carson munitions testing in the surrounding area. There is more land available in the area that may actually have a stronger wind resource than the measured meteorological site, but this land is privately owned. If this land should become available for development, a larger wind farm would be possible with access to transmission lines on the private property. Such a project, because of its larger size, would have better economics.

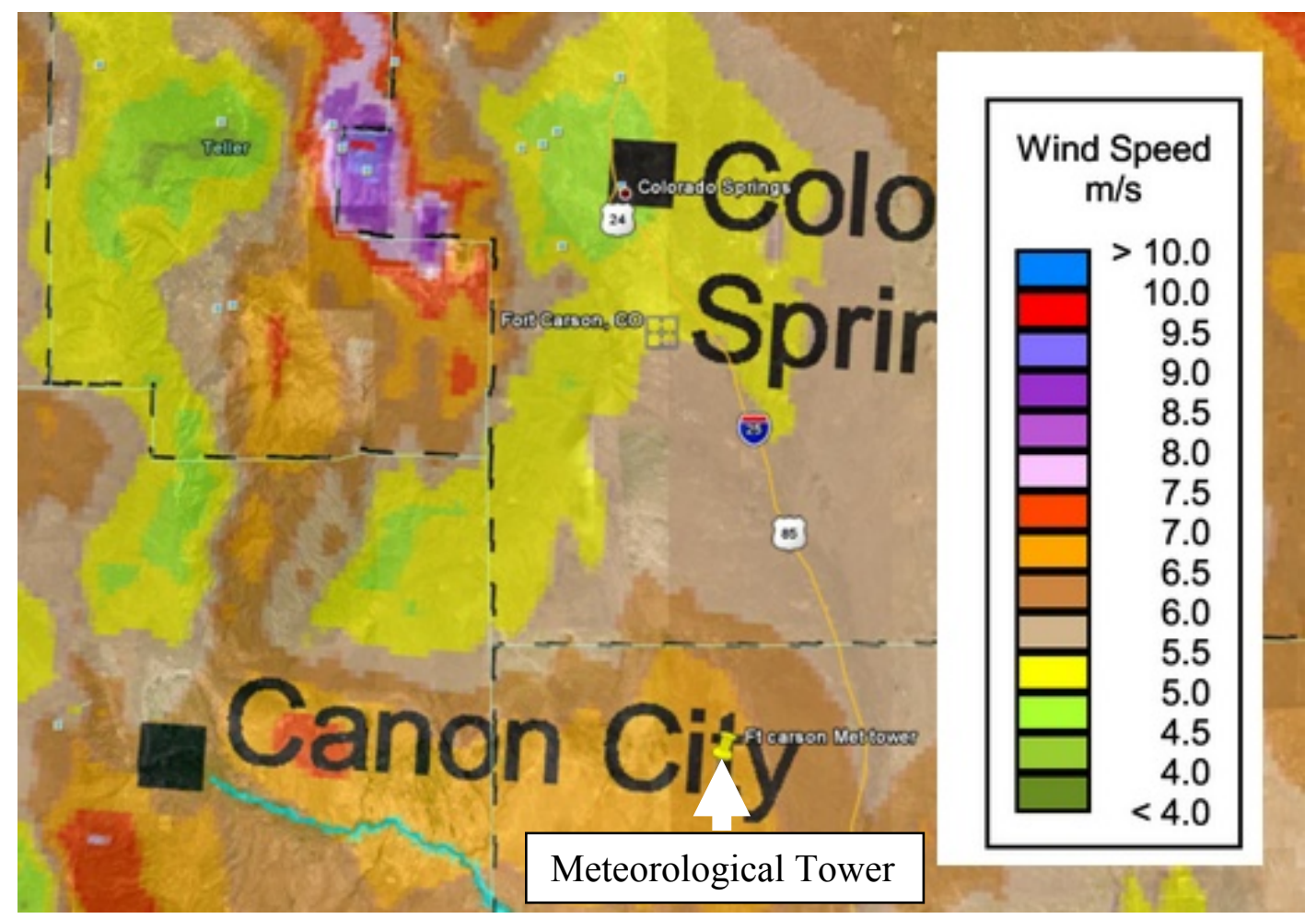

Figure 22. Wind resources in the Fort Carson area (Credit: Owen Roberts, NREL) 


\subsubsection{Economic Analysis}

Table 14 shows an economic analysis of wind power at Fort Carson.

Table 14. Economic Analysis of Wind Power

\begin{tabular}{|l|r|}
\hline Wind Capacity (kW) & $\mathbf{1 0 , 5 0 0}$ \\
\hline Wind Initial Cost (\$) & $19,509,000$ \\
\hline Wind Federal Tax Credit (\$) & $5,852,700$ \\
\hline Wind Initial Cost with incentives $(\$)$ & $13,656,300$ \\
\hline Wind Production Incentive (\$/year) & 17,967 \\
\hline Wind Annual Energy Delivery (kWh/year) & $17,967,104$ \\
\hline Capacity Factor (\%) & $19.5 \%$ \\
\hline Wind Annual Cost Savings (\$) & 916,740 \\
\hline Wind Annual O\&M Cost (\$/year) & 216,000 \\
\hline Wind Payback Period (years) & 19 \\
\hline
\end{tabular}

\subsubsection{Recommendations}

Of all potential electricity-producing renewables at Fort Carson, wind has the shortest payback period. Despite this, the cost still remains higher than the current price of fossil fuel-generated electricity. GE evaluated a wind farm at Fort Carson, and estimated the electricity would cost $\$ 0.10 / \mathrm{kWh}$. In the future, as electricity prices increase, the on-site project may make better economic sense. Another option would be to bundle the on-site project with a lower-cost off-site project like Baca County. Under this scenario, the overall price might be $\$ 0.07 / \mathrm{kWh}$.

\subsection{Photovoltaic (PV) Power}

\subsubsection{Technology Overview}

PV panels convert sunlight directly into electricity. They have no moving parts, require very little maintenance, make no noise, and emit no pollution. They are highly reliable and last 25 years or longer. They may be installed on racks on the ground, mounted on poles, or mounted on rooftops or carports.

\subsubsection{Planned or Existing Projects}

Fort Carson has the Army's largest solar array, a 2 MW ground-mounted system completed in January 2008 (see Figure 23). In 2009 the base had the opportunity to build a second 1.3 MW array near the housing, but delays in the land lease caused the developer to move on to another project. 


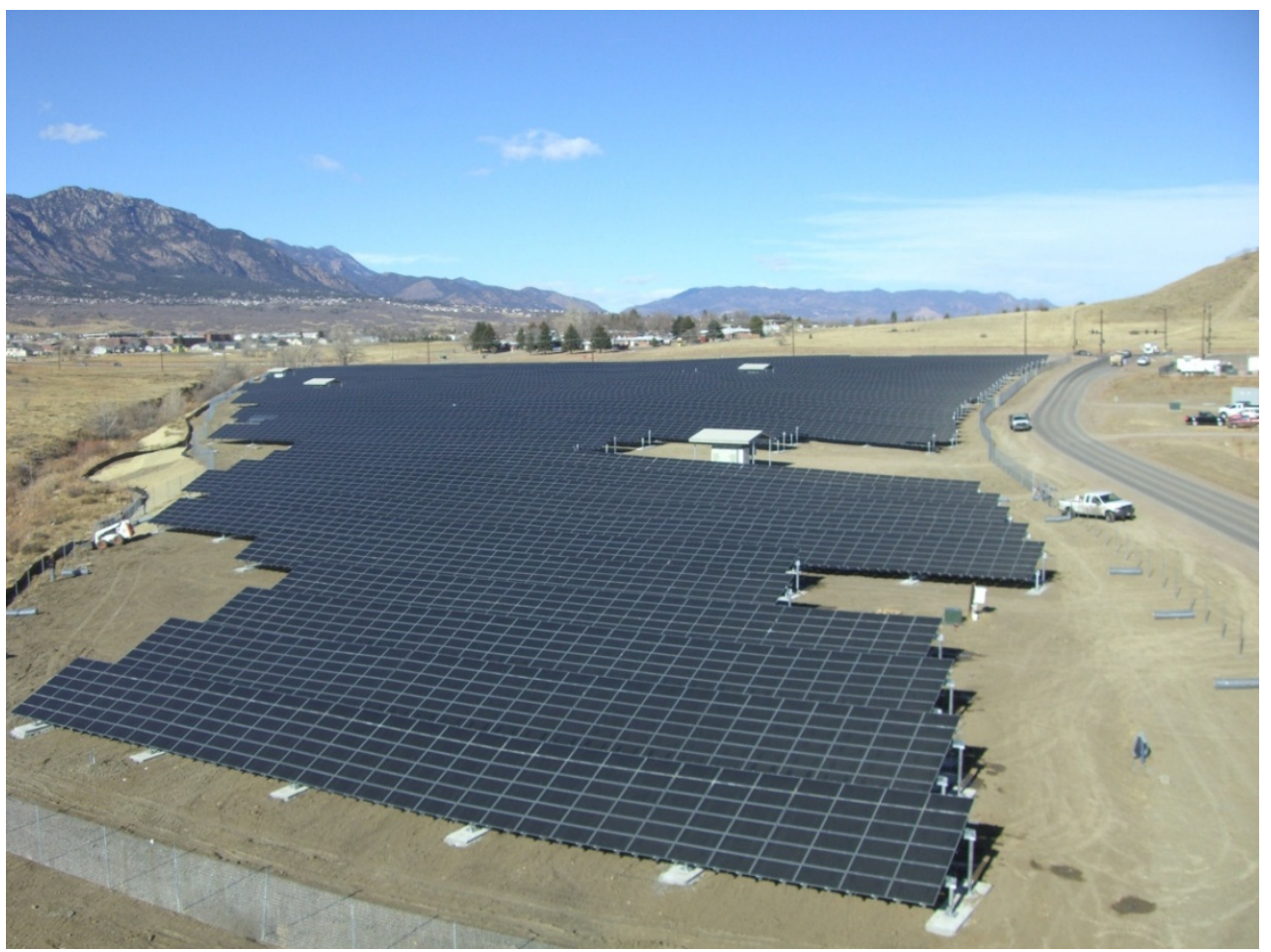

Figure 23. Fort Carson 2-MW solar array (Credit: U.S. Army Fort Carson, PIX 17394)

\subsubsection{Analysis}

Fort Carson has ample rooftop, parking, and ground space for additional PV arrays. NREL analyzed satellite images of parking lot and rooftop space in the proposed microgrid area and identified locations for $10.74 \mathrm{MW}$ of PV. Figure 24 shows the locations identified. Note that it would be necessary to build carports in the parking lots to accommodate PV. 


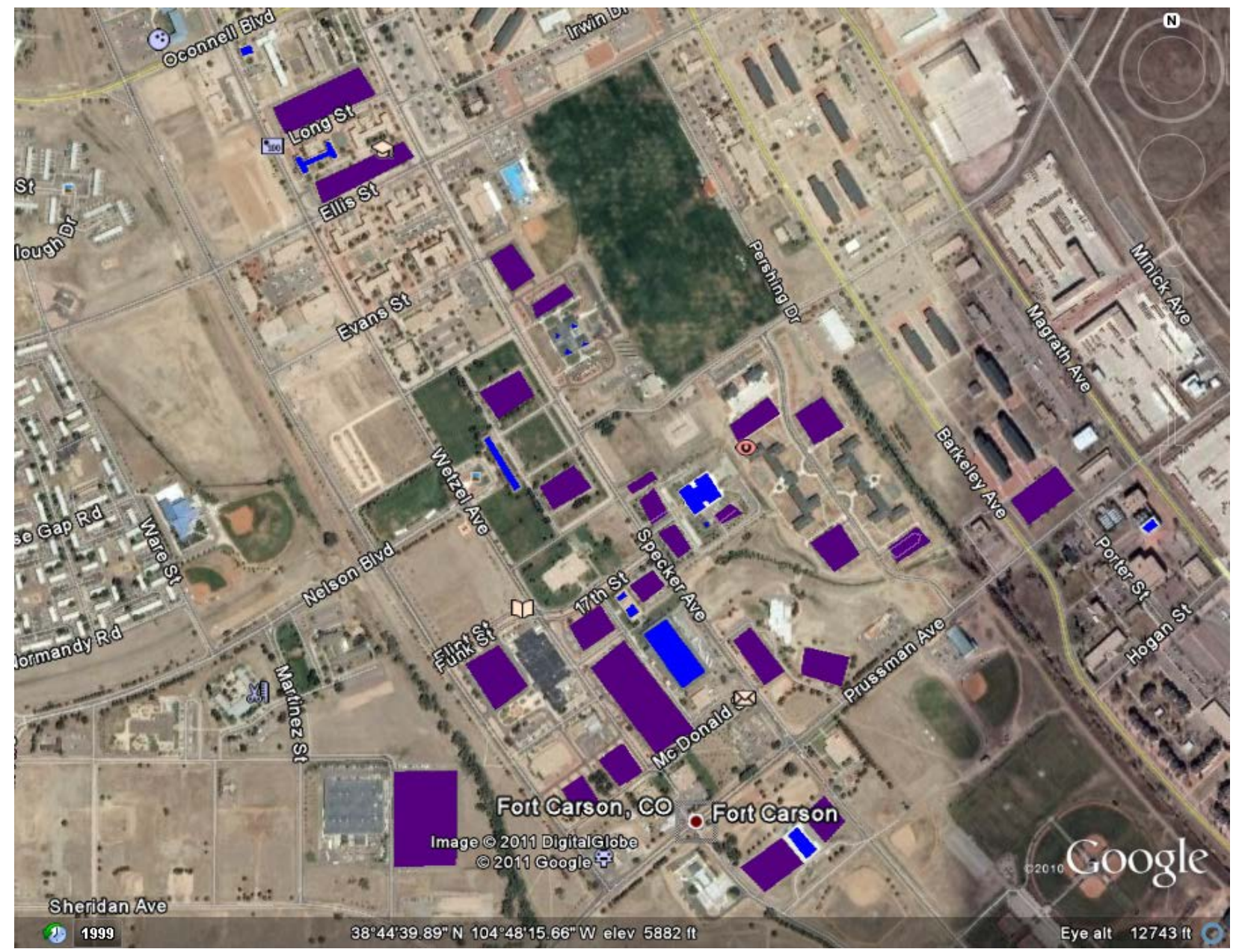

Figure 24. Potential rooftop (blue) and carport (purple) locations in the microgrid area

Based on building square footages and an estimated average rooftop space availability factor of $25 \%$, we estimate that there is room for an additional $23 \mathrm{MW}$ of rooftop PV on the rest of the base. Parking areas on the rest of the base could hold over $100 \mathrm{MW}$ of PV. In addition to rooftop and carport locations, Fort Carson master planners have identified potential locations for $18 \mathrm{MW}$ of ground-mounted PV projects. These include areas north and south of the existing array, pockets around the airfield (where height restrictions prevent the land being used for other purposes), and a large area on the northeast side of the base, west of I- 25 .

Table 15 summarizes total potential PV capacity at Fort Carson. In total, we estimate that the base could mount 165.8 MW of PV on rooftops, carports, and ground areas around the installation. 
Table 15. Potential PV Capacity at Fort Carson

\begin{tabular}{|c|c|c|c|c|}
\hline & $\begin{array}{r}\text { Approximate } \\
\text { Area }\end{array}$ & $\begin{array}{r}\text { Estimated } \\
\text { Space for } \\
\text { PV }\end{array}$ & $\begin{array}{r}\text { Estimated } \\
\text { PV Array } \\
\text { Size }\end{array}$ & $\begin{array}{r}\text { Estimated } \\
\text { AC Energy }\end{array}$ \\
\hline Site & $\left(\mathrm{ft}^{2}\right)$ & $(\%)$ & $(\mathrm{kW})$ & (kWh/year) \\
\hline \multicolumn{5}{|c|}{ Ground mount PV $-20^{\circ}$ tilt fixed } \\
\hline Signal Hill & 310,000 & $100 \%$ & 1,200 & $1,750,732$ \\
\hline Airfield Area 1 & 480,000 & $100 \%$ & 2,000 & $2,917,886$ \\
\hline Airfield Area 2 & 480,000 & $100 \%$ & 2,000 & $2,917,886$ \\
\hline Airfield Area 3 & 480,000 & $100 \%$ & 2,000 & $2,917,886$ \\
\hline $\begin{array}{l}\text { Former landfill south } \\
\text { of existing array }\end{array}$ & 260,000 & $100 \%$ & 1,000 & $1,458,943$ \\
\hline $\begin{array}{l}\text { NE corner of base near } \\
\text { I- } 25\end{array}$ & $2,600,000$ & $100 \%$ & 10,000 & $14,589,430$ \\
\hline Total & & & 18,200 & $26,552,763$ \\
\hline \multicolumn{5}{|c|}{ Rooftop PV $-39^{\circ}$ tilt fixed } \\
\hline Bld 1014 & 3,250 & $100 \%$ & 33 & 49,368 \\
\hline Bld 1118 & 11,723 & $100 \%$ & 117 & 178,072 \\
\hline Bld 1430 & 10,329 & $100 \%$ & 103 & 156,898 \\
\hline Bld 1435 & 0 & $100 \%$ & 0 & \\
\hline Bld 1444 & 2,400 & $100 \%$ & 24 & 36,456 \\
\hline Bld 1525 & 52,700 & $100 \%$ & 527 & 800,513 \\
\hline Bld 1526 & 4,807 & $100 \%$ & 48 & 73,018 \\
\hline Bld 1550 & 25,330 & $100 \%$ & 253 & 384,763 \\
\hline Bld 1551 & 1,416 & $100 \%$ & 14 & 21,509 \\
\hline Bld 1805 & 4,221 & $100 \%$ & 42 & 64,117 \\
\hline Bld 1829 & 17,930 & $100 \%$ & 179 & 272,357 \\
\hline Bld 1860 & 2,554 & $100 \%$ & 26 & 38,795 \\
\hline $\begin{array}{l}\text { Other Buildings } \\
\text { outside microgrid area }\end{array}$ & $9,145,340$ & $25 \%$ & 22,863 & $34,729,429$ \\
\hline Total & & & 24,230 & $36,805,294$ \\
\hline \multicolumn{5}{|c|}{ Carport PV- $0^{\circ}$ tilt fixed } \\
\hline Carport for Bld 1525 & 155,383 & $80 \%$ & 1,243 & $1,538,915$ \\
\hline Carport for Bld 6110 & 222,441 & $80 \%$ & 1,780 & $2,203,052$ \\
\hline Carport for Bld 1610 & 68,638 & $80 \%$ & 549 & 679,790 \\
\hline Carport for Bld 1511A & 30,635 & $80 \%$ & 245 & 303,404 \\
\hline Carport for Bld 1511B & 32,193 & $80 \%$ & 258 & 318,839 \\
\hline Carport for Bld 1532A & 55,281 & $80 \%$ & 442 & 547,498 \\
\hline Carport for Bld 1532B & 40,455 & $80 \%$ & 324 & 400,665 \\
\hline Carport for Bld 1526A & 34,083 & $80 \%$ & 273 & 337,559 \\
\hline Carport for Bld. 1526B & 18,533 & $80 \%$ & 148 & 183,554 \\
\hline Carport for Bld. 1829A & 58,679 & $80 \%$ & 469 & 581,159 \\
\hline
\end{tabular}




\begin{tabular}{|l|r|r|r|r|}
\hline Carport for Bld. 1829B & 38,509 & $80 \%$ & 308 & 381,396 \\
\hline carport for Bld. 1550A & 6,977 & $80 \%$ & 56 & 69,096 \\
\hline Carport for Bld. 1550B & 14,185 & $80 \%$ & 113 & 140,490 \\
\hline Carport for Bld 1550 C & 22,136 & $80 \%$ & 177 & 219,232 \\
\hline Carport for Bld. 1551 & 11,144 & $80 \%$ & 89 & 110,375 \\
\hline Carport for Bld. 1552A & 31,323 & $80 \%$ & 251 & 310,221 \\
\hline Carport for Bld. 1552B & 41,105 & $80 \%$ & 329 & 407,107 \\
\hline Carport for Bld 1554A & 38,519 & $80 \%$ & 308 & 381,490 \\
\hline Carport for Bld 1554B & 27,106 & $80 \%$ & 217 & 268,457 \\
\hline Carport for Bld 1013 & 96,344 & $80 \%$ & 771 & 954,192 \\
\hline Carport for Bld. 1118 & 70,253 & $80 \%$ & 562 & 695,789 \\
\hline Carport for Bld 1444A & 21,863 & $80 \%$ & 175 & 216,531 \\
\hline Carport for Bld 1444B & 36,282 & $80 \%$ & 290 & 359,336 \\
\hline Other carports 0utside & & & & \\
microgrid area & $14,250,000$ & $80 \%$ & 114,000 & $141,132,000$ \\
\hline Total & & & $\mathbf{1 2 3 , 3 7 7}$ & $\mathbf{1 5 2 , 7 4 0 , 1 5 0}$ \\
\hline Total & & & $\mathbf{1 6 5 , 8 0 6}$ & $\mathbf{2 1 6 , 0 9 8 , 2 0 7}$ \\
\hline
\end{tabular}

Table 16 shows the assumptions we used for energy output, energy density, and cost for each system type.

Table 16. PV Systems Energy and Cost Assumptions

\begin{tabular}{|l|r|r|r|}
\hline $\begin{array}{r}\text { System Type } \\
\text { Roof Top Mount 39 Degree }\end{array}$ & $\begin{array}{r}\text { Annual energy } \\
(\mathbf{k W h} / \mathbf{k W})\end{array}$ & $\begin{array}{r}\text { Installed Cost } \\
(\$ / W)\end{array}$ & $\begin{array}{r}\text { Energy Density } \\
\left(\mathbf{W} / \mathbf{f t}^{2}\right)\end{array}$ \\
\hline $\begin{array}{l}\text { Tilt } \\
\text { Ground Mount 20 Degree }\end{array}$ & 1,519 & $\$ 6.00$ & 10 \\
\hline Fixed Tilt & 1,459 & $\$ 5.00$ & 3.8 \\
\hline Carport, 0 Degree Tilt & 1,238 & $\$ 7.50$ & 10 \\
\hline
\end{tabular}

\subsubsection{Economic Analysis}

NREL carried out an economic analysis for $1 \mathrm{MW}$ ground mount, rooftop, and carport systems. Assuming a 30\% Federal tax credit and REC sale at $\$ 0.05 / \mathrm{kWh}$, paybacks vary from $26-46$ years, as Table 17 shows. 
Table 17. PV Economic Analysis

\begin{tabular}{|c|c|}
\hline \multicolumn{2}{|l|}{ Ground Mount } \\
\hline PV Capacity $(\mathrm{kW})$ & 1,000 \\
\hline Initial Cost $(\$)$ & $5,000,000$ \\
\hline$\overline{\text { REC Sale }(\$ / y r)}$ & 72,950 \\
\hline Federal Tax Credit (\$) & $1,500,000$ \\
\hline Annual Energy Delivery (kWh/yr) & $1,459,000$ \\
\hline Annual Utility Cost Savings (\$) & 72,950 \\
\hline Annual O\&M Cost $(\$ / y r)$ & 9,932 \\
\hline Payback Period (yrs) & 26 \\
\hline \multicolumn{2}{|l|}{ Rooftop } \\
\hline PV Capacity (kW) & 1,000 \\
\hline Initial Cost $(\$)$ & $6,000,000$ \\
\hline REC Sale (\$/yr) & 75,950 \\
\hline Federal Tax Credit (\$) & $1,800,000$ \\
\hline Annual Energy Delivery ( $\mathrm{kWh} / \mathrm{yr})$ & $1,519,000$ \\
\hline Annual Utility Cost Savings (\$) & 75,950 \\
\hline Annual O\&M Cost $(\$ / y r)$ & 9,932 \\
\hline Payback Period (yrs) & 30 \\
\hline \multicolumn{2}{|l|}{ Carport } \\
\hline PV Capacity (kW) & 1,000 \\
\hline Initial Cost $(\$)$ & $7,500,000$ \\
\hline REC Sale $(\$ / y r)$ & 61,900 \\
\hline Federal Tax Credit (\$) & $2,250,000$ \\
\hline Annual Energy Delivery $(\mathrm{kWh} / \mathrm{yr})$ & $1,238,000$ \\
\hline Annual Utility Cost Savings (\$) & 61,900 \\
\hline Annual O\&M Cost $(\$ / y r)$ & 9,932 \\
\hline Payback Period (yrs) & 46 \\
\hline
\end{tabular}

\subsubsection{Recommendations}

Fort Carson has a number of potential sites for PV installation on ground areas, rooftops, and carports. Ground mount systems have the best payback period and Fort Carson has past experience funding large ground mount systems through power purchase agreements (PPAs). Therefore we recommend pursuing these opportunities first. Fort Carson may also be able to fund individual rooftop systems through Army Corps of Engineer building funds.

\subsection{Solar Hot Water}

\subsubsection{Technology Overview}

Solar water heating systems consist of solar collectors to capture the sun's heat and tanks to store the hot water for later use. Operation is similar to a hydronic heating system, with the solar collectors as heat sources, heat exchangers to heat potable water, pumps to circulate the fluid, expansion tanks, pressure relief valves, flush and fill valves, and controls. There are three types 
of solar water heating collectors: 1) unglazed plastic collectors for low temperatures such as swimming pool heating; 2) glazed, insulated flat plate collectors for mid-temperature service hot water; and 3) evacuated tube collectors with reflectors for high temperature applications. Typical solar water heating systems provide $40-70 \%$ of water-heating requirements. They are often installed on rooftops.

\subsubsection{Existing or Planned Projects}

Fort Carson has a solar hot water heating system installed at its indoor pool, as Figure 25 shows.

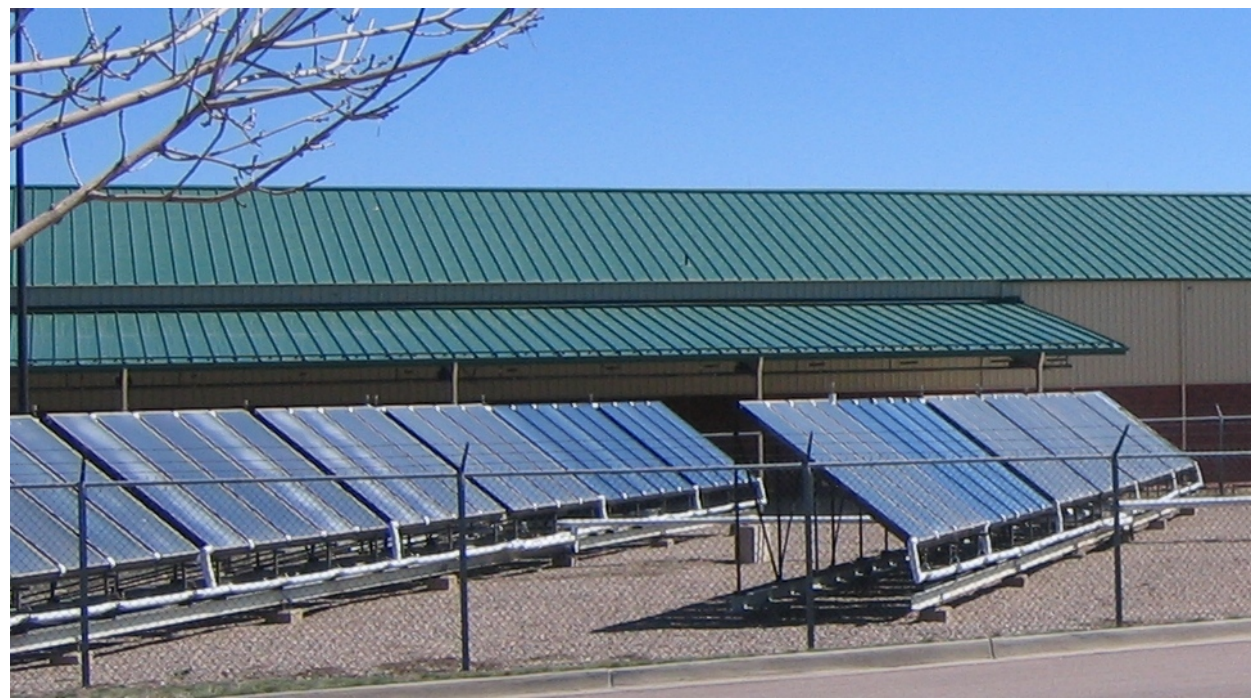

Figure 25. Solar hot water at Fort Carson indoor pool (Credit: John Leahey, NREL)

\subsubsection{Analysis}

Table 18 identifies opportunities for solar water heating. We selected these buildings based on building type, but further analysis of building orientation, roof type, and roof space is still needed. 
Table 18. Potential Candidates for Solar Hot Water System

\begin{tabular}{|c|c|c|c|c|c|c|}
\hline $\begin{array}{l}\text { Building } \\
\text { Number }\end{array}$ & Name & $\begin{array}{l}\text { Building } \\
\text { Type }\end{array}$ & $\begin{array}{l}\text { Building } \\
\text { Size }\left(\mathrm{ft}^{2}\right)\end{array}$ & $\begin{array}{c}\text { Estimated } \\
\text { Hot Water } \\
\text { Load (KBtu) }\end{array}$ & $\begin{array}{c}\% \\
\text { Served } \\
\text { by Solar } \\
\text { Thermal }\end{array}$ & $\begin{array}{l}\text { MMBtu } \\
\text { reduction }\end{array}$ \\
\hline 1040 & Cheyenne Dining Facility & Dining & 13,280 & 87,714 & $60 \%$ & 53 \\
\hline 1369 & $\begin{array}{r}\text { Mountaineer Dining } \\
\text { Facility }\end{array}$ & Dining & 13,280 & 87,714 & $60 \%$ & 53 \\
\hline 2161 & Patton Dining Facility & Dining & 18,222 & 120,355 & $60 \%$ & 72 \\
\hline 2061 & Striker Dining Facility & Dining & 18,222 & 120,355 & $60 \%$ & 72 \\
\hline 2461 & Warhorse Dining Facility & Dining & 16,724 & 110,461 & $60 \%$ & 66 \\
\hline 1444 & Wolf Dining Facility & Dining & 28,621 & 189,040 & $60 \%$ & 113 \\
\hline 1856 & Garcia Gym & Gym & 23,159 & 25,485 & $60 \%$ & 15 \\
\hline 1843 & Forrest Gym & Gym & 17,502 & 19,259 & $60 \%$ & 12 \\
\hline 1160 & McKibben Gym & Gym & 20,375 & 22,421 & $60 \%$ & 13 \\
\hline 2357 & Waller Gym & Gym & 24,895 & 27,395 & $60 \%$ & 16 \\
\hline 1661 & WCAP Fitness Center & Gym & 13,280 & 14,614 & $60 \%$ & 9 \\
\hline 1219 & ARMY LODGING & Lodging & 18,012 & 304,678 & $60 \%$ & 183 \\
\hline 7302 & ARMY LODGING & Lodging & 36,027 & 609,406 & $60 \%$ & 366 \\
\hline 7303 & ARMY LODGING & Lodging & 12,746 & 215,602 & $60 \%$ & 129 \\
\hline 7304 & ARMY LODGING & Lodging & 36,027 & 609,406 & $60 \%$ & 366 \\
\hline 7305 & ARMY LODGING & Lodging & 12,330 & 208,565 & $60 \%$ & 125 \\
\hline 7500 & MED CTR/HOSP & Clinic & 513,700 & $14,499,785$ & $60 \%$ & 8,700 \\
\hline 1041 & HEALTH CLINIC & Clinic & 11,321 & 319,549 & $60 \%$ & 192 \\
\hline 2353 & HEALTH CLINIC & Clinic & 10,080 & 284,520 & $60 \%$ & 171 \\
\hline 7490 & HEALTH CLINIC & Clinic & 15,110 & 426,497 & $60 \%$ & 256 \\
\hline 756 & ENLISTED UPH & Barracks & 95,858 & $1,621,462$ & $60 \%$ & 973 \\
\hline 758 & ENLISTED UPH & Barracks & 95,858 & $1,621,462$ & $60 \%$ & 973 \\
\hline 1000 & ENLISTED UPH & Barracks & 63797 & $1,079,142$ & $60 \%$ & 647 \\
\hline 1013 & ENLISTED UPH & Barracks & 23,246 & 393,212 & $60 \%$ & 236 \\
\hline 1043 & ENLISTED UPH & Barracks & 40,639 & 687,419 & $60 \%$ & 412 \\
\hline 1044 & ENLISTED UPH & Barracks & 40,639 & 687,419 & $60 \%$ & 412 \\
\hline 1046 & ENLISTED UPH & Barracks & 40,639 & 687,419 & $60 \%$ & 412 \\
\hline 1047 & ENLISTED UPH & Barracks & 40,639 & 687,419 & $60 \%$ & 412 \\
\hline 1219 & ENLISTED UPH & Barracks & 14,549 & 246,100 & $60 \%$ & 148 \\
\hline 1363 & ENLISTED UPH & Barracks & 40,639 & 687,419 & $60 \%$ & 412 \\
\hline 1364 & ENLISTED UPH & Barracks & 40,639 & 687,419 & $60 \%$ & 412 \\
\hline 1365 & ENLISTED UPH & Barracks & 40,639 & 687,419 & $60 \%$ & 412 \\
\hline
\end{tabular}




\begin{tabular}{|c|c|c|c|c|c|c|}
\hline 1366 & ENLISTED UPH & Barracks & 40,639 & 687,419 & $60 \%$ & 412 \\
\hline$\overline{1367}$ & ENLISTED UPH & Barracks & 40,639 & 687,419 & $60 \%$ & 412 \\
\hline 1449 & ENLISTED UPH & Barracks & 93,297 & $1,578,142$ & $60 \%$ & 947 \\
\hline 1552 & ENLISTED UPH & Barracks & 123,860 & $2,095,123$ & $60 \%$ & 1,257 \\
\hline 1554 & ENLISTED UPH & Barracks & 123,860 & $2,095,123$ & $60 \%$ & 1,257 \\
\hline 1663 & ENLISTED UPH & Barracks & 40,639 & 687,419 & $60 \%$ & 412 \\
\hline 1664 & ENLISTED UPH & Barracks & 40,639 & 687,419 & $60 \%$ & 412 \\
\hline 1665 & ENLISTED UPH & Barracks & 40,639 & 687,419 & $60 \%$ & 412 \\
\hline 1666 & ENLISTED UPH & Barracks & 40,639 & 687,419 & $60 \%$ & 412 \\
\hline 1667 & ENLISTED UPH & Barracks & 40,639 & 687,419 & $60 \%$ & 412 \\
\hline 1950 & ENLISTED UPH & Barracks & 11,819 & 199,921 & $60 \%$ & 120 \\
\hline 1951 & ENLISTED UPH & Barracks & 22,386 & 378,665 & $60 \%$ & 227 \\
\hline 1952 & ENLISTED UPH & Barracks & 22,386 & 378,665 & $60 \%$ & 227 \\
\hline 1953 & ENLISTED UPH & Barracks & 22,386 & 378,665 & $60 \%$ & 227 \\
\hline 1954 & ENLISTED UPH & Barracks & 22,386 & 378,665 & $60 \%$ & 227 \\
\hline 2050 & ENLISTED UPH & Barracks & 22,386 & 378,665 & $60 \%$ & 227 \\
\hline 2051 & ENLISTED UPH & Barracks & 22,386 & 378,665 & $60 \%$ & 227 \\
\hline 2052 & ENLISTED UPH & Barracks & 22,386 & 378,665 & $60 \%$ & 227 \\
\hline 2053 & ENLISTED UPH & Barracks & 11,819 & 199,921 & $60 \%$ & 120 \\
\hline 2054 & ENLISTED UPH & Barracks & 22,386 & 378,665 & $60 \%$ & 227 \\
\hline 2070 & ENLISTED UPH & Barracks & 11,819 & 199,921 & $60 \%$ & 120 \\
\hline 2071 & ENLISTED UPH & Barracks & 22,386 & 378,665 & $60 \%$ & 227 \\
\hline 2072 & ENLISTED UPH & Barracks & 22,386 & 378,665 & $60 \%$ & 227 \\
\hline 2073 & ENLISTED UPH & Barracks & 22,386 & 378,665 & $60 \%$ & 227 \\
\hline 2074 & ENLISTED UPH & Barracks & 22,386 & 378,665 & $60 \%$ & 227 \\
\hline 2144 & ENLISTED UPH & Barracks & 152,684 & $2,582,689$ & $60 \%$ & 1,550 \\
\hline 2146 & ENLISTED UPH & Barracks & 152,684 & $2,582,689$ & $60 \%$ & 1,550 \\
\hline 2150 & ENLISTED UPH & Barracks & 22,386 & 378,665 & $60 \%$ & 227 \\
\hline 2151 & ENLISTED UPH & Barracks & 22,386 & 378,665 & $60 \%$ & 227 \\
\hline 2152 & ENLISTED UPH & Barracks & 22,386 & 378,665 & $60 \%$ & 227 \\
\hline 2153 & ENLISTED UPH & Barracks & 11,819 & 199,921 & $60 \%$ & 120 \\
\hline 2154 & ENLISTED UPH & Barracks & 22,386 & 378,665 & $60 \%$ & 227 \\
\hline 2250 & ENLISTED UPH & Barracks & 11,819 & 199,921 & $60 \%$ & 120 \\
\hline 2251 & ENLISTED UPH & Barracks & 22,386 & 378,665 & $60 \%$ & 227 \\
\hline 2252 & ENLISTED UPH & Barracks & 22,386 & 378,665 & $60 \%$ & 227 \\
\hline 2253 & ENLISTED UPH & Barracks & 22,386 & 378,665 & $60 \%$ & 227 \\
\hline 2254 & ENLISTED UPH & Barracks & 22,386 & 378,665 & $60 \%$ & 227 \\
\hline
\end{tabular}




\begin{tabular}{|r|r|r|r|r|r|r|}
\hline $\mathbf{2 3 4 0}$ & ENLISTED UPH & Barracks & 152,684 & $2,582,689$ & $60 \%$ & 1,550 \\
\hline $\mathbf{2 3 4 4}$ & ENLISTED UPH & Barracks & 152,684 & $2,582,689$ & $60 \%$ & 1,550 \\
\hline $\mathbf{2 3 4 6}$ & ENLISTED UPH & Barracks & 152,684 & $2,582,689$ & $60 \%$ & 1,550 \\
\hline $\mathbf{2 4 5 0}$ & ENLISTED UPH & Barracks & 22,441 & 379,595 & $60 \%$ & 228 \\
\hline $\mathbf{2 4 5 1}$ & ENLISTED UPH & Barracks & 22,441 & 379,595 & $60 \%$ & 228 \\
\hline $\mathbf{2 4 5 2}$ & ENLISTED UPH & Barracks & 22,441 & 379,595 & $60 \%$ & 228 \\
\hline $\mathbf{2 4 5 3}$ & ENLISTED UPH & Barracks & 22,441 & 379,595 & $60 \%$ & 228 \\
\hline $\mathbf{2 4 5 4}$ & ENLISTED UPH & Barracks & 22,441 & 379,595 & $60 \%$ & 228 \\
\hline $\mathbf{2 5 5 0}$ & ENLISTED UPH & Barracks & 22,441 & 379,595 & $60 \%$ & 228 \\
\hline $\mathbf{2 5 5 1}$ & ENLISTED UPH & Barracks & 22,441 & 379,595 & $60 \%$ & 228 \\
\hline $\mathbf{2 5 5 2}$ & ENLISTED UPH & Barracks & 22,441 & 379,595 & $60 \%$ & 228 \\
\hline $\mathbf{2 5 5 4}$ & ENLISTED UPH & Barracks & 22,441 & 379,595 & $60 \%$ & 228 \\
\hline $\mathbf{7 4 8 0}$ & ENLISTED UPH & Barracks & 60,217 & $1,018,586$ & $60 \%$ & 611 \\
\hline $\mathbf{7 4 8 2}$ & ENLISTED UPH & Barracks & 60,217 & $1,018,586$ & $60 \%$ & 611 \\
\hline $\mathbf{7 5 0 6}$ & ENLISTED UPH & Barracks & 49,560 & 838,320 & $60 \%$ & 503 \\
\hline $\mathbf{9 4 7 1}$ & MOB ENL BRKS & Barracks & 30,410 & 514,393 & $60 \%$ & 309 \\
\hline $\mathbf{9 4 7 2}$ & MOB ENL BRKS & Barracks & 30,410 & 514,393 & $60 \%$ & 309 \\
\hline $\mathbf{9 4 7 3}$ & MOB ENL BRKS & Barracks & 30,410 & 514,393 & $60 \%$ & 309 \\
\hline $\mathbf{9 4 7 4}$ & MOB ENL BRKS & Barracks & 30,410 & 514,393 & $60 \%$ & 309 \\
\hline $\mathbf{8 1 1}$ & TT ENL BARRACKS & Barracks & 35,560 & 601,506 & $60 \%$ & 361 \\
\hline $\mathbf{8 1 2}$ & TT ENL BARRACKS & Barracks & 31,305 & 529,532 & $60 \%$ & 318 \\
\hline & & & & & $\mathbf{4 1 , 7 7 4}$ \\
\hline
\end{tabular}

For the net zero analysis, we assume that half of these installations will be viable, resulting in a total of 43,441 square feet of solar hot water area and 20,887 MMBtu of annual energy savings.

\subsubsection{Economic Analysis}

Table 19 shows estimated costs, savings, and payback for installing solar hot water systems on the buildings identified in Table 18.

Table 19. Solar Hot Water Financial Estimate

\begin{tabular}{|l|r|}
\hline Solar Water Heating Area $\left(\mathrm{ft}^{2}\right)$ & $\mathbf{4 3 , 4 4 1}$ \\
\hline Solar Water Heating Initial Cost (\$) & $\mathbf{\$ 3 , 0 2 6 , 7 8 6}$ \\
\hline Rebates and Incentives (\$) & 0 \\
\hline Solar Water Heating Gas Savings (MIMBtu/yr) & 20,887 \\
\hline Solar Water Heating Annual Utility Cost Savings (\$/yr) & $\$ 115,603$ \\
\hline Solar Water Heating O\&M Cost (\$/yr) & $\$ 15,134$ \\
\hline Solar Water Heating Payback Period (yrs) & $\mathbf{3 0 . 1}$ \\
\hline
\end{tabular}




\subsubsection{Recommendations}

Our assessment indicates that solar hot water systems would not be cost-effective at Fort Carson at this time. With a lifetime of 15-30 years, the system is likely to fail before the initial investment has been repaid. It may be possible to reduce the payback period by implementing systems through a private party—-such as energy savings performance contracts (ESPC) or utility energy services contracts (UESC) - which can take advantage of Federal tax incentives. Systems may also become more cost-effective as fossil energy prices increase, as many observers predict. If Fort Carson does pursue solar hot water systems, we recommend giving priority to dining facilities, gyms, barracks, and the new pool.

\subsection{Biomass}

\subsubsection{Technology Overview}

Several technologies are available to convert biomass feedstocks into heat and electricity. In this analysis, we evaluate combustion, the direct burning of a feedstock such as wood waste with air to produce steam, which can then be used to create both heat and power. This is typically the most economical method of converting biomass fuel to heat and power.

\subsubsection{Planned or Existing Projects}

Fort Carson has received two unsolicited proposals for biomass systems:

1. The first proposal is for a combined heat and power (CHP) direct combustion system. NREL conducted a detailed study of a CHP plant capable of providing $5 \mathrm{MW}$ of thermal power and $7 \mathrm{MW}$ of electrical power. These levels were selected based on Fort Carson's seasonal heat load and a desire to maximize electricity production.

2. The second proposal is for a heat-only system. Under an energy purchase agreement, a wood-fired combustion boiler would supply hot water (30 MMBtu/hr) to the existing central distribution system at an estimated $\$ 15-20 / \mathrm{MMBtu}$.

Each of these options is evaluated below.

\subsubsection{Analysis}

The National Energy Technology Laboratory (NETL)'s biomass resource database indicates there is 187,275 tons of woody biomass within a 50 mile radius of the base; Fort Carson personnel estimate that an additional 10,000 tons of woody biomass exists on site (see Table 20).

Table 20. Biomass and Alternative Methane Fuel Resources near Fort Carson, CO

\begin{tabular}{|c|c|c|c|c|c|}
\hline & Radius & $\begin{array}{r}\text { Number of } \\
\text { Sources } \\
\end{array}$ & $\begin{array}{r}\text { Total Resource } \\
\text { (Green } \\
\text { Tons/Year) } \\
\end{array}$ & $\begin{array}{r}\text { Estimated } \\
\text { Energy } \\
(\mathrm{MMBtu}) \\
\end{array}$ & $\begin{array}{r}\text { Estimated } \\
\text { Power } \\
(\mathrm{MWe}) \\
\end{array}$ \\
\hline Industrial Wood Residue & 50 & 34 & 48,620 & 131,274 & 4.39 \\
\hline $\begin{array}{l}\text { Western Forest Fire } \\
\text { Mitigation Residue } \\
\end{array}$ & 50 & 5 & 138,655 & 374,367 & 12.52 \\
\hline Fort Carson & 0 & 1 & 10,000 & 27,000 & 0.90 \\
\hline TOTAL & & & 197,275 & 532,641 & 17.81 \\
\hline
\end{tabular}


This is a sufficient supply of biomass fuel to supply either of the proposed systems; however, there are other, competing users of biomass. The primary challenge to fuel procurement will be competition from the nearby Colorado Springs Utilities' biomass co-firing project at its Drake plant, which is expected to consume 100,000 tons of woody biomass fuel per year. This project will certainly pressure the existing supplier base while promoting the development of additional biomass fuel procurement, processing, and delivery options.

\subsubsection{Economic Analysis}

\section{Combined Heat and Power System}

NREL conducted a detailed feasibility analysis of a CHP system that would supply $5 \mathrm{MW}$ of thermal power and $7 \mathrm{MW}$ of electrical power to the post. The study found local market conditions for biomass fuel are unfavorable for the development of a biomass-fired heat and power system. The originally proposed system was based on a delivered price for biomass fuel of $\$ 30$ per ton. Actual market research found only one vendor capable of providing fuel near this price point. However, the quality of their fuel was not adequate for a Fort Carson project.

The actual delivered price to ship biomass of adequate quality from off post was found to be $\$ 50-\$ 60$ per ton. This is the price currently paid by Colorado Springs Utilities at the Drake biomass plant, and is significantly above the national average, primarily due to lengthy transport required from forestry biomass sources in the region. Assuming $25 \%$ moisture content and 8,000 Btu per bone-dry pound, the adjusted cost for the heating value of the fuel is \$4.58/MMBtu.

Current estimates indicate 10,000 tons of woody biomass may be procured from sources on Fort Carson property each year. We estimate that the delivered cost for this material would be $\$ 20$ per ton. Adjusting for moisture, the cost for the heating value of this fuel is approximately $\$ 1.79 /$ MMBtu. This resource is much more economical but would reduce or eliminate a popular firewood program on post. Fort Carson's firewood program provides soldiers and their families with low-cost firewood, and discontinuing the program is undesirable.

The biomass CHP plant (supplying $5 \mathrm{MW}$ thermal power and $7 \mathrm{MW}$ of electrical power) would require approximately 100,000 tons of biomass fuel per year to operate. If 10,000 tons were procured on post, with 90,000 tons imported from other locations, the blended rate for heat is $\$ 4.30 / \mathrm{MMBtu}$. The cost of producing electricity from biomass is much higher due to the low efficiency of converting the heat to electricity. Assuming 20\% conversion efficiency, the blended rate for electricity is about $\$ 21.50 / \mathrm{MMBtu}$. O\&M costs will add approximately $\$ 5-6 / \mathrm{MMBtu}$, resulting in a rate closer to $\$ 27 / \mathrm{MMBtu}$. For comparison, Fort Carson's 2009 costs were $\$ 5.44 / \mathrm{MMBtu}$ for heat input into its system and \$14.65/MMBtu for electricity.

Using 2009 natural gas and electric rates and the above assumptions for biomass fuel costs, a biomass CHP plant would provide annual utility heating and electricity savings of $\$ 1.456$ million. The additional operating expense however, primarily due to the expense of biomass fuel, is $\$ 13.1$ million. This huge operating expense makes a CHP project economically unviable at this time. Table 21 outlines the economics for this scenario. 
Table 21. Economic Analysis of Biomass CHP

\begin{tabular}{|l|r|}
\hline 2009 Delivered Cost of Natural Gas & $\$ 5.44$ \\
\hline Blended Delivered Cost for Biomass Heat & $\$ 4.30$ \\
\hline Annual Heat Produced (MMBtu) & 200,000 \\
\hline Annual Heat Savings (\$/year) & $\$ 228,000$ \\
\hline 2009 Cost of Electricity (\$/kWh) & $\$ 0.05$ \\
\hline Annual Electricity Production (kWh) & $24,552,000$ \\
\hline Annual Electricity Savings (\$) & $\$ 1,227,600$ \\
\hline Total Annual Utility Savings & $\$ \mathbf{1 , 4 5 5 , 6 0 0}$ \\
\hline Annual O\&M (\$/year) & $\mathbf{\$ 1 3 , 1 1 7 , 0 0 0}$ \\
\hline Capital Cost for New Plant & $\$ 61,300,000$ \\
\hline Simple Payback (years) & Negative \\
\hline
\end{tabular}

Sensitivity analysis indicates that an increase in the utility electricity rate to approximately $\$ 0.26 / \mathrm{kWh}$ would result in a positive net present value for the project. A rate of about $\$ 0.30 / \mathrm{kWh}$ would provide a $12 \%$ rate of return, and make the project attractive to a potential developer.

\section{Heat-Only System}

The proposed $30 \mathrm{MMBtu} / \mathrm{hr}$ biomass heating project would require approximately 16,000 tons of biomass per year to operate. The majority of this amount (10,000 tons) may be procured on site, with the remaining 6,000 tons imported. Using the respective costs for these sources of $\$ 1.79$ and $\$ 4.58$, the blended rate is $\$ 2.84 / \mathrm{MMBtu}$. Again using $\$ 5.44 / \mathrm{MMBtu}$ as the natural gas cost benchmark, and presuming a $30 \mathrm{MMBtu} / \mathrm{hr}$ project can meet $80 \%$ of Fort Carson's heating demand (peak times will require an additional boiler), there is a potential savings of $\$ 416,000$ per year in heating costs. Based on estimated capital and O\&M costs, the payback for this project is 29.3 years. 
Table 22. Economic Analysis of Biomass Heat Only

\begin{tabular}{|l|r|}
\hline 2009 Delivered Cost of Natural Gas & $\$ 5.44$ \\
\hline Blended Delivered Cost for Biomass Heat & $\$ 2.84$ \\
\hline Annual Heat Produced (MMBtu) & 160,000 \\
\hline Annual Heat Savings (\$/year) & $\$ 416,000$ \\
\hline Additional O\&M (\$/year) & $\$ 75,000$ \\
\hline Capital Cost for New Plant & $\$ 10,000,000$ \\
\hline Simple Payback (years) & 29.3 \\
\hline
\end{tabular}

\subsubsection{Permitting and Site Selection}

The current heating plant is located in a congested area with little room for expansion. There is a site approximately 200 yards northeast of the current facility, at the perimeter of the currently developed area. This site would provide room for necessary fuel storage, would reduce the plant's impact on nearby operations and residents, and would facilitate fuel deliveries. We recommend meeting with Fort Carson's Master Planner to determine the viability of this location. The new facility would be tied into the current heating distribution point by running lines to the current heating building and connecting there. The existing facility will remain in place and operable, serving as an installed backup for the sake of redundancy.

Supplying thousands of tons of material each year could be potentially disruptive to base operations. We recommend delivery trucks enter Gate 3, use O'Connell Boulevard, and keep close to the base perimeter on MacGrath Avenue to minimize disturbance.

In addition to master planner approval, the facility would require significant permitting including:

- Air Permit. May require Title V and Potential for Significant Deterioration (PSD) permitting, pending results from the EPA's review of its Tailoring Rule.

- New Source Review. Fort Carson is in a maintenance zone for carbon monoxide and a non-attainment zone for ozone.

- NEPA Study. A National Environmental Policy Act (NEPA) study shows that there is potential concern for impact on endangered wildlife and on troop training areas.

Initial, Final, and Title V permits will be secured by the contractor and are expected to take 2430 months to attain after the project is awarded.

\subsubsection{Recommendations}

NREL's analysis determined a biomass CHP plant is not viable. A small heating-only plant may still be viable. We recommend continued review of this option, including the collection of detailed cost estimates and further discussion with the post's firewood program managers to determine the impact of using this resource. Also, continued monitoring of the local biomass market will help determine if the Colorado Springs Utilities project promotes the development of local resources and allows lower-cost biomass fuel to be procured. 


\subsection{Other Combined Heat and Power Options}

Because a biomass-fueled combined heat and power plant is economically unviable at this time, other cogeneration options that use non-renewable fuels were evaluated. While these options would still require the use of natural gas, they would provide a reduction in source energy, because electricity generated on site suffers fewer transmission losses than electricity that is generated off site and transported through the transmission grid. The non-renewable cogeneration option would also reduce the installation's overall carbon footprint, since electrical energy generated with natural gas has a lower carbon fuel requirement than the average generation mix of CSU. In addition, the waste heat from the generation process would be utilized on base. If Fort Carson pursues these options, we recommend the evaluation of renewable natural gas supplies as well. Using renewable natural gas to power cogeneration units would increase net zero energy potential and further reduce the base's carbon footprint. In the sections immediately following, we discuss three cogeneration options: natural gas cogeneration, microturbines, and fuel cells.

\section{Natural Gas Cogeneration}

Natural gas cogeneration units typically serve large-scale residential, commercial, or industrial applications. System sizes typically are $500 \mathrm{~kW}$ or greater. The most common technologies used for a cogeneration system is a natural gas powered turbine or internal combustion engine.

A natural gas cogeneration system, which produces electricity, hot water, and chilled water, was evaluated for the NREL campus in Golden, $\mathrm{CO}$, where heat and electricity rates are similar to Fort Carson's ${ }^{12}$. Results show a 4.2 MW Wartsilla internal combustion engine would reduce greenhouse gases by $39 \%$ with a simple payback of 8.47 years. A 4.6 MW Mercury 50 gas turbine would reduce greenhouse gases by $36 \%$ with a payback of 14.52 years. Fort Carson would likely use a larger system closer to its average load of $20 \mathrm{MW}$. For systems over $10 \mathrm{MW}$, the electrical efficiencies of gas turbines increase substantially, and payback for a $20 \mathrm{MW}$ system at Fort Carson could be less than 10 years.

\section{Microturbines}

\subsubsection{Technology Overview}

Microturbines are small combustion turbines with outputs between $5 \mathrm{~kW}$ and $500 \mathrm{~kW}$ (see photo in Figure 26). They are best suited to supply the load of individual buildings at Fort Carson that are not served by the central heating plant. These small systems are most economical when the user is able to take advantage of both the thermal and electrical energy that the system produces. Microturbines can be coupled with existing building energy systems and should be sized so that the heat output of the turbine is less than the building's load. The heat from the microturbine can also be used in conjunction with an adsorption chiller to cool a building. The best candidates for this type of equipment are buildings that are not on centralized systems and have natural gas loads above 1,500 MMBtu annually. Electrical efficiency is typically between $15 \%$ and $40 \%$; thermal use can make the total efficiency as high as about $90 \%$.

\footnotetext{
${ }^{12}$ Dean, Jesse. "Design of a Hybrid Distributed Generation System for NREL's South Table Mountain Campus." University of Colorado, Boulder. April 29,2010.
} 


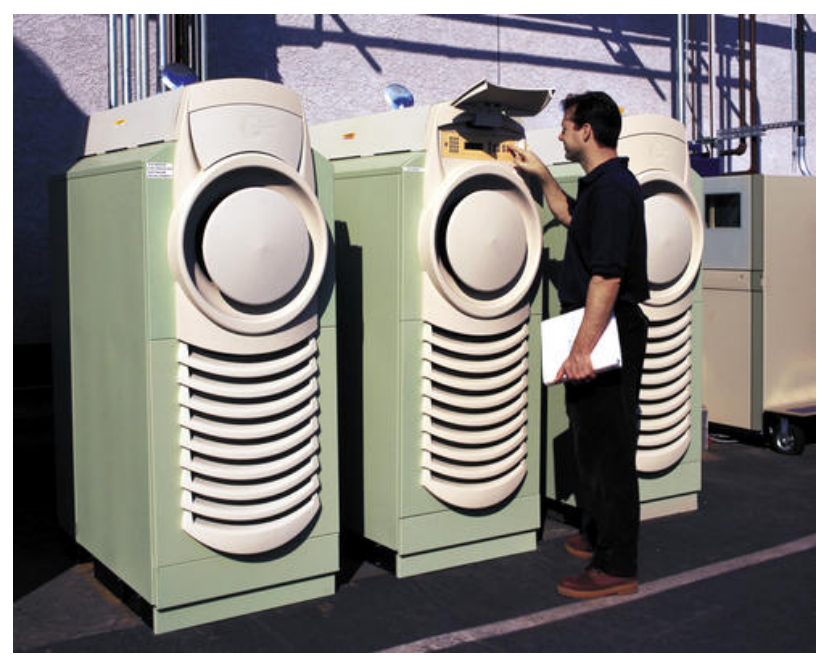

Figure 26. 30 kW Capstone Microturbines (Credit: Capstone Turbine Corporation, PIX 08130)

\subsubsection{Economic Analysis}

NREL carried out an economic analysis of microturbines for Fort Carson (see Table 23). We found that microturbines are not cost-effective at this time, because the price of electricity is low compared to the price of natural gas. The cost of a Btu of electricity needs to be approximately four times the cost of a Btu of natural gas in order to justify the capital cost for a microturbine installation. At Fort Carson's 2009 natural gas price of \$5.44/MMBtu, the price of electricity would need to rise from the current $\$ 0.050 / \mathrm{kWh}$ to at least $\$ 0.075 / \mathrm{kWh}$ to make microturbines life-cycle cost effective within a 25 year period. At the current natural gas rate of \$6.26/MMBtu, the price of electricity would need to rise to at least $\$ 0.081 / \mathrm{kWh}$. 
Table 23. Microturbine Analysis

\begin{tabular}{|l|r|}
\hline \multicolumn{2}{|c|}{ Base Case Natural Gas Heating } \\
\hline Natural Gas Load (MMBtu) & 2,000 \\
\hline Estimated Boiler Efficiency & $80 \%$ \\
\hline Heating MMBtu Required & 1,600 \\
\hline Natural Gas Cost (\$MMBtu) & 5.44 \\
\hline Total Natural Gas Cost & $\$ 10,880$ \\
\hline \multicolumn{1}{|c|}{ Microturbine CHP } \\
\hline Microturbine Electrical Efficiency & $25 \%$ \\
\hline Microturbine Thermal Efficiency & $35 \%$ \\
\hline Total Efficiency & $60 \%$ \\
\hline Natural Gas Load (MMBtu) & 4,571 \\
\hline Heating MMBtu Required & 1,600 \\
\hline MMBtu Converted to Electric & 1,143 \\
\hline kWh Produced & 334,854 \\
\hline Natural Gas Cost (\$MMBtu) & $\$ 5.44$ \\
\hline Total Natural Gas Cost & $\$ 24,866$ \\
\hline Value of Electrical Energy (per & \\
\hline kWh) & $\$ 0.05$ \\
\hline Total Electrical Energy Value & $\$ 16,743$ \\
\hline System Size Required (kW) & 38 \\
\hline Installed System Size (kW) & 63,516 \\
\hline Installed Cost (\$/kW) & $\$ \$ 760)$ \\
\hline Total Cost & Negative \\
\hline Annual Maintenance (\$/kWh) & $\$ 130,500$ \\
\hline Annual Maintenance Cost & \\
\hline Annual Saving & \\
\hline Simple Payback (yrs) & \\
\hline
\end{tabular}

\subsubsection{Recommendations}

While not cost-effective now, CSU is predicting that electric rates will rise sharply in coming years. Therefore, microturbines may become cost-effective in the future for buildings that are not on the central heat distribution system. Additionally, when replacing old boilers at Fort Carson, the base should compare the capital cost of a new boiler with a microturbine system, as this scenario would likely provide more favorable economic conditions for the installation of a microturbine. Microturbines would strengthen a microgrid at Fort Carson and provide backup power in an islanded scenario. 


\section{Fuel Cells}

\subsubsection{Technology Overview}

Fuel cells offer another option for CHP at Fort Carson. Fuel cells have high efficiency and low emissions in comparison with other conventional cogeneration systems. There are several different types of fuel cells, such as phosphoric acid, proton exchange membrane (PEM), solid oxide, and molten carbonate. The fuel source for these cells is typically hydrogen or a methanebased fuel, such as natural gas or renewably derived biogas. Fuel cell systems are sized based primarily on the thermal load that can be displaced in a particular area. The electrical energy produced by the fuel cell would be put into the base distribution network and could be utilized anywhere on base; however, the thermal load must be used on site. Housing areas, with their high space heating and domestic hot water needs, are prime candidates.

During a grid outage, the fuel cell power plant disconnects from the utility grid in milliseconds and then continues to produce power to serve the customer's critical loads. This "island" operation would strictly serve dedicated loads (as well as the loads of the fuel cell system itself), without allowing any power to be exported to an otherwise unpowered utility grid. After power returns to the utility grid and is stable, the fuel cell is designed to automatically synchronize its power to the grid, while providing continuous power to the critical loads. If critical backup is not required by the customer, then the fuel cell power system uses island mode to maintain power for its own process loads and remains ready for reconnection to the utility grid on return of live-grid power.

\subsubsection{Economic Analysis}

NREL carried out an economic analysis of fuel cells for Fort Carson (see Table 24). This analysis looks at a $1400 \mathrm{~kW}$ cell with $40 \%$ electrical efficiency and $80 \%$ overall efficiency. The heat produced by this system would displace about 40,000 MMBtu annually, or about one-fifth the annual natural gas use of Fort Carson's privatized housing. 
Table 24. Area 5 Fuel Cell Analysis

\begin{tabular}{|c|c|}
\hline \multicolumn{2}{|c|}{ Base Case Natural Gas Heating } \\
\hline Natural Gas Load (MMBtu) & 40,000 \\
\hline Estimated Boiler Efficiency & $80 \%$ \\
\hline Heating MMBtu Required & 32,000 \\
\hline Natural Gas Cost (\$/MMBtu) & 5.44 \\
\hline Total Natural Gas Cost & $\$ 217,600$ \\
\hline \multicolumn{2}{|c|}{ Fuel Cell CHP } \\
\hline Fuel Cell Electrical Efficiency & $40 \%$ \\
\hline Fuel Cell Thermal Efficiency & $40 \%$ \\
\hline Total Efficiency & $80 \%$ \\
\hline Natural Gas Load (MMBtu) & 80,000 \\
\hline Heating MMBtu Required & 32,000 \\
\hline MMBtu Converted to Electric & 32,000 \\
\hline kWh Produced & $9,378,664$ \\
\hline Natural Gas Cost (\$/MMBtu) & $\$ 5.44$ \\
\hline Total Natural Gas Cost & $\$ 435,200$ \\
\hline $\begin{array}{l}\text { Value of Electrical Energy (per } \\
\mathrm{kWh} \text { ) }\end{array}$ & $\$ 0.05$ \\
\hline Total Electrical Energy Value & $\$ 468,933$ \\
\hline Installed System Size (kW) & 1,400 \\
\hline Installed Cost $(\$ / k W)$ & $\$ 4,500$ \\
\hline Total Cost & $\$ 6,300,000$ \\
\hline Annual Maintenance (\$/kWh) & $\$ 0.01$ \\
\hline Annual Maintenance Cost & $\$ 103,165$ \\
\hline Annual Saving & $\$ 148,168$ \\
\hline Simple Payback (yrs) & 43 \\
\hline
\end{tabular}

Our analysis found that fuel cells are not cost-effective at this time, because of the low price of electricity compared to natural gas at Fort Carson. For fuel cells to be life-cycle cost effective over a 25 year period, Fort Carson's electricity price would need to increase to $\$ 0.075 / \mathrm{kWh}$ (versus the current $\$ 0.05 / \mathrm{kWh}$ ) compared to Fort Carson's 2009 natural gas price of \$5.44/MMBtu.

\subsubsection{Recommendations}

While not cost-effective now, CSU is predicting that electric rates will rise sharply in coming years, so fuel cells may become cost-effective in the future for buildings that are not on the central heat distribution system. Additionally, fuel cells are only in the early stages of commercialization, with many technologies still under development. Costs will likely decrease 
as technologies improve. In an islanded scenario, fuel cells would strengthen a microgrid at Fort Carson and provide backup power.

\section{Overall CHP Recommendation}

CHP provides a promising opportunity for Fort Carson to reduce costs, reduce emissions, and increase energy security at the base. Natural gas powered cogeneration appears to be the most economically viable technology, and we recommend evaluating opportunities to convert the central heat plant to a combined heat and power plant. In the future, if electric prices increase significantly compared to natural gas prices, we recommend considering microturbines or fuel cells.

\subsection{Concentrating Solar Power \\ 6.8.1 Technology Overview}

Electricity and steam can be produced through a solar thermal process using concentrating solar power (CSP). Collectors focus solar heat onto a fluid, the heat creates steam, which turns a turbine or engine attached to a generator to create electricity. Motors and controls track the sun. Although these systems include minimal moving parts, they do require preventative and unscheduled maintenance. Two concentrating solar power production technologies are dish Stirling engines and parabolic troughs. Commercial dish Stirling engines are usually about 1 MW in size. Commercial parabolic troughs range from 50-200 MW, and require 5-10 acres of land per megawatt. Trough designs incorporating thermal energy storage can provide baseload power.

\subsubsection{Planned Project}

Fort Carson is planning a CSP demonstration project. The base has submitted an Environmental Security Technology Certification Program (ESTCP) proposal to demonstrate an Infinia $3 \mathrm{~kW}_{\mathrm{e}}$ SolarDish, a dish Stirling engine that is integrated into a building system to provide $7 \mathrm{~kW}_{\mathrm{t}}$ for space heating and hot water, in addition to $3 \mathrm{~kW}_{\mathrm{e}}$ of electric power. The proposal will demonstrate one dish, but there is potential to scale the system to larger sizes by adding additional units. The small size makes it easier to site, because it does not require the large contiguous land areas required by conventional trough systems. The system is expected to generate $7,400 \mathrm{kWh}$ AC electricity and $22,000 \mathrm{kWh}$ of thermal energy annually. System cost information is not currently available.

Fort Carson is also a part of the Front Range Renewable Energy Consortium (FRREC), which is considering a $\sim 100 \mathrm{MW}$ CSP parabolic trough project. The consortium is considering two tracts of land: 1) the Nixon power plant, adjacent to the southeast corner of Fort Carson; and 2) the Pueblo Chemical Depot. Although neither of these sites lie within the Fort Carson boundary, so would not meet the net zero definition of on-site renewable generation, either site could nonetheless provide a source of off-site renewable energy.

\subsubsection{Analysis}

NREL used the Solar Advisory Model (SAM) to analyze the potential for a CSP trough project on site at Fort Carson. Potential sites include 1) land in the northeast corner of the installation between the main site and I-25, or 2) part of the land currently used for training on the south side of the installation. Use of either of these sites would require support from Fort Carson's Master 
Planners and the current users (range/training). Neither of these areas has been surveyed for suitability. A trough system will require relatively flat land.

Fort Carson's electrical demand averages about $21 \mathrm{MW}$ throughout most of the year, rising to 25 MW in the summer and dropping just below $20 \mathrm{MW}$ in the fall. For this analysis, we evaluate the costs and energy savings associated with a $20 \mathrm{MW}$ system. This is small compared to most commercial parabolic trough systems, and results in a higher cost of energy than would be attained with a larger system. However, larger tracts of land are not currently available at Fort Carson. We analyzed both north-south and east-west orientations, and recommended an eastwest orientation. The east-west system produces $6 \%$ less energy annually than a north-south system, resulting in a slightly higher levelized cost of energy (LCOE), but, importantly, it provides a more constant level of power. Between summer and winter, the daily energy output of the north-south systems varied by a multiple of two to three times.

Parabolic trough plants can incorporate thermal energy storage (TES) by storing the heat transfer fluid or a dedicated thermal storage fluid at high temperature for later use. This analysis evaluated storage options from 0-18 hours. We selected the field and TES size to minimize LCOE and avoid energy dumping. Storage was capped at 18 hours full-load capacity to avoid excessive pumping losses for the large solar field.

This analysis assumes all energy generated will be used to produce electricity. It may also be possible, however, to use the steam directly for heating by connecting the CSP system to the centralized steam distribution network on the north end of the installation. Cost and feasibility would depend on the site of the CSP plant and its proximity to existing steam lines.

\subsubsection{Economic Analysis}

Table 25 outlines the economics of a 20 MW system with six hours of thermal storage. We calculated a simple payback period, assuming that the project is implemented through a private party to take advantage of Federal tax credits, and the RECs are sold. 
Table 25. CSP Energy Generation and Costs

\begin{tabular}{|c|c|}
\hline Solar Field Size $\left(\mathrm{m}^{2}\right)$ & 278,182 \\
\hline Plant Footprint (acres) & 54 \\
\hline Thermal Storage (hours) & 6 \\
\hline $\begin{array}{l}\text { Annual Power Generation } \\
\text { (MWh) }\end{array}$ & 50,000 \\
\hline $\begin{array}{l}\text { Percent of Fort Carson Annual } \\
\text { Energy Use }(\%)\end{array}$ & $31 \%$ \\
\hline LCOE (\$/kWh) & 19.86 \\
\hline Installed Cost (\$) & $184,000,000$ \\
\hline Federal Tax Credit (\$) & $55,200,000$ \\
\hline REC Sale (\$/yr) & $2,500,000$ \\
\hline Annual O\&M Cost (\$/yr) & $1,750,000$ \\
\hline Annual Utility Savings (\$/yr) & $2,500,000$ \\
\hline Simple Payback Period (yr) & 40 \\
\hline
\end{tabular}

\subsubsection{Recommendations}

The NREL analysis shows that CSP has potential for being an effective resource at Fort Carson. The ability to store energy makes CSP a good option for baseload renewable energy at the installation, where energy dependability is of great importance. The analysis shows that the lifecycle cost of energy is $\$ 0.1986 / \mathrm{kWh}$ for a $20 \mathrm{MW}$ system with six hours of thermal storage. It would be possible to add more thermal storage without much effect on the life-cycle cost of energy, but this would require a larger solar collector and therefore more land. Because the ability to produce at constant level is important for the base, an east-west oriented collector field makes the most sense for Fort Carson.

CSP systems of the size considered here are not cost-competitive with current fossil energy prices. If CSP costs decrease, or if fossil energy prices significantly increase, we would recommend reevaluating a CSP project. Until then, we recommend pursuing the joint FRREC CSP project, which will be more cost competitive because of its larger size.

\subsection{Ground Source Heat Pumps 6.9.1 Technology Overview}

Ground source heat pumps (GSHPs) are used for space heating, space cooling and water heating. GSHPs use the earth as a heat source/sink, operating through a series of pipes buried in the ground. A pump circulates a fluid through the pipes (water, or a mixture of water and antifreeze) that absorbs heat from, or relinquishes heat to, the surrounding soil, depending on whether the ambient air is colder or warmer than the soil. The technology relies on the fact that the earth (beneath the surface) remains at a relatively constant temperature throughout the year, warmer than the air above it during the winter and cooler in the summer. The geothermal heat pump takes advantage of this geological fact by transferring heat stored in the earth or in ground water 
into a building during the winter, and transferring it out of the building and back into the ground during the summer.

GSHPs can serve almost any building with both heating and cooling in a wide range of building sizes, from 100 to 1 million square feet. Large buildings may require multiple GSHPs. The same ground loop may serve multiple smaller buildings. GSHPs are most cost-effective when replacing old equipment, when used in extreme climates (with cold winters, hot summers, or large daily temperature swings), and when electricity is less than three times as expensive per Btu as heating fuels. They tend not to be cost effective in buildings without both heating and cooling requirements, buildings without ductwork, newer buildings (less than four years old), buildings in mild climates, buildings with air source heat pumps, or buildings on central energy plants.

\subsubsection{Existing or Planned Projects}

Fort Carson has recently installed several GSHP in new construction at the Band Training Facility, Soldier Family Assistance Center, and at a school. The installation plans a fourth system for a new child development center.

\subsubsection{Analysis}

NREL conducted a high level analysis of potential ground source heat pump savings across the installation (see Table 26). 
Table 26. Potential Energy Savings from Ground Source Heat Pumps

\begin{tabular}{|c|c|}
\hline \multicolumn{2}{|c|}{ Current cost of heating and cooling individual buildings } \\
\hline 2009 natural gas use (MMBtu) & 921,407 \\
\hline $\begin{array}{l}\text { Percent of natural gas that goes to individual buildings } \\
\text { (not central heat plant) }(\%)\end{array}$ & $80 \%$ \\
\hline $\begin{array}{l}\text { Percent of natural gas used for space heating } \& \text { cooling } \\
\text { (versus water heating and cooking) }(\%)\end{array}$ & $70 \%$ \\
\hline Natural gas used for space heating and cooling (MMBtu) & 515,988 \\
\hline Natural gas rate (\$/MMBtu) & $\$ 5.44$ \\
\hline Current heating and cooling cost & $2,806,976$ \\
\hline \multicolumn{2}{|l|}{ GSHP cost of heating and cooling } \\
\hline Natural gas used for space heating and cooling (MMBtu) & 515,988 \\
\hline Average boiler efficiency (\%) & $80 \%$ \\
\hline Energy needed for space heating and cooling (MMBtu) & 412,791 \\
\hline Average GSHP coefficient of performance & 3 \\
\hline Electricity needed for GSHP (MMBtu) & 137,597 \\
\hline Electric Rate (\$/MMBtu) & $\$ 14.65$ \\
\hline GSHP heating and cooling cost (\$) & $\$ 2,016,366$ \\
\hline \multicolumn{2}{|l|}{ Savings } \\
\hline Annual Energy Savings (MMBtu) & 378,391 \\
\hline Annual Cost Savings (\$) & $\$ 790,609$ \\
\hline \multicolumn{2}{|l|}{ GSHP Size } \\
\hline Buildings with individual heating systems $\left(\mathrm{ft}^{2}\right)$ & $12,100,000$ \\
\hline GSHP Size $\left(\right.$ tons $\left./ \mathrm{ft}^{2}\right)$ & 0.0015 \\
\hline Total GSHP needed (tons) & 18,150 \\
\hline \multicolumn{2}{|l|}{ Economics } \\
\hline GSHP cost (\$/ton) & $\$ 2,500$ \\
\hline Initial Cost (\$) & $\$ 45,375,000$ \\
\hline Annual Savings (\$/year) & $\$ 790,609$ \\
\hline Simple Payback period (years) & 57 \\
\hline
\end{tabular}

This analysis shows that GSHP are generally not cost-effective for retrofits.

Pacific Northwest National Laboratory (PNNL) also conducted an analysis of GSHPs at Fort Carson in 2008. ${ }^{13}$ That analysis considered differences in building types and heating system

${ }^{13}$ Chvala, W.D.; Solana, A.E.; Sates, J.C.; Warwick, W.M.; Weimar, M.R., Reilly, R.W., and Dixon, D.R. Renewable Energy Opportunities at Fort Carson, Colorado. PNNL-18132. Pacific Northwest National Laboratory. December 2008. 
types. PNNL found that open loop configurations were economic for 992,000 square feet of building space ( $9 \%$ of buildings). In general, buildings with chillers and boilers with air handling units were most cost-effective, while buildings with air source heat pumps and fan coils were never cost-effective. Small- to medium-size buildings, primarily administration buildings built in the 1960s-1970s, are likely to be cost-effective for GSHP retrofits. Closed-loop systems were not cost-effective at any building except the recreational support facilities that uses electric heating and cooling.

Open-loop systems require a water source and sink. The source can be a well or open body of water; the sink can be a secondary well, the same or alternate body of water, or a storm drain. Water volume requirements are typically 1.5-3.0 gallons/minute per cooling ton. This requirement may affect the feasibility of the system. Local codes and regulations may also affect feasibility, as many areas do not want to risk groundwater depletion or contamination.

DoD also conducted an analysis of GSHPs at DoD facilities. ${ }^{14}$ That analysis found that GSHPs are most commonly used in DoD family housing in the eastern half of the United States, where they are most cost-effective. GSHPs have not been widely used in other areas of the country. Modeling indicates, however, that vertical-bore GSHP systems installed with conventional HVAC equipment would be cost-effective in the Mountain West. The analysis found that vertical-bore systems alone were generally not cost-effective, although this depends on sitespecific conditions.

If Fort Carson installed GSHPs in all buildings that use individual building heating systems (rather than heat from the central heat plant), the potential savings would be 378,391 MMBtu/year. If we assume $9 \%$ of these installations are cost-effective (based on PNNL's assessment), the potential cost-effective savings would be 34,055 MMBtu from 1,633 tons of GSHP.

\subsubsection{Recommendations}

Based on the analyses by NREL, PNNL, and DoD, it appears that GSHPs may be cost-effective as retrofits in selected buildings. We recommend evaluating GSHPs for any building where boilers need replacing. We also recommend evaluating GSHPs in new construction, where GSHPs may be more economical because ground loops can be installed at the same time as the digging of the foundation and because the GSHP system reduces the size of other HVAC equipment.

\subsection{Daylighting}

\subsubsection{Technology Overview}

A complete daylighting system consists of apertures (skylights) to admit and distribute solar light and a controller to modulate artificial light in order to achieve energy cost savings. Daylighting requires no scheduled maintenance, although skylights may add to roof maintenance.

Daylighting is screened by using a site's solar illuminance values (from our GIS resource database) to determine the optimum amount of skylight area (as a percentage of total roof

\footnotetext{
${ }^{14}$ Office of the Deputy Under Secretary of Defense (Installations and Environment). Ground Source Heat Pumps at Department of Defense Facilities. January 2007.
} 
area).We balance savings from reduced electric light usage against the cost of installing a daylighting system and the expense of heat loss through the skylights.

\subsubsection{Economic Analysis}

Table 27 shows an economic analysis of retrofitting daylighting in existing buildings.

Table 27. Daylighting Economic Analysis

\begin{tabular}{|c|c|}
\hline Daylighting Office Skylight/Floor Area Ratio & $5 \%$ \\
\hline Total Skylight Area $\left(\mathrm{ft}^{2}\right)$ & 770,000 \\
\hline Annual Electric Savings (kWh/year) & $19,057,357$ \\
\hline Annual Natural Gas Savings (therms/year) & $(299,703)$ \\
\hline Total Annual Savings (MMBtu/year) & 35,053 \\
\hline Daylighting Capital Cost (\$) & $\$ 115,740,394$ \\
\hline State Tax Credit (\$) & $\$-$ \\
\hline Federal Tax Credit (\$) & $\$-$ \\
\hline Rebate (\$) & $\$-$ \\
\hline Daylighting Cost with incentives (\$) & $\$ 115,740,394$ \\
\hline Daylighting Annual Cost Savings (\$/year) & $\$ 787,436$ \\
\hline Daylighting Payback Period (years) & 147 \\
\hline
\end{tabular}

\subsubsection{Recommendations}

The NREL analysis shows that retrofitting daylighting in most existing buildings is not costeffective. There may still be some opportunity for cost-effective installation in warehouse-type buildings with uninsulated metal roofs, but for other building types, retrofitting is generally not cost-effective. Daylighting, however, can be incorporated at no additional cost in the design stage of a building, so we recommend that all new construction at Fort Carson incorporate daylighting strategies.

\subsection{Waste-to-Energy}

\subsubsection{Technology Overview}

Waste-to-energy generates energy through incineration of municipal solid waste (MSW). There are several technologies for converting MSW to energy. Mass burn, the most common, directly combusts MSW as a fuel with minimal processing. Refuse-derived fuel (RDF) pre-processes waste into pelletized fuel and then burns it on its own or co-fires it with other fuels (like coal). In pyrolysis or thermal gasification, waste is decomposed at a high temperature with little or no oxygen in order to generate a producer gas, which can then be combusted to generate heat and electricity in a boiler or combustion turbine. Pyrolysis technology is still under development. Challenges for WTE include disposal of possibly hazardous ash residue and controlling air pollution. 


\subsubsection{Economic Analysis}

Fort Carson generates about 8,778 tons of municipal solid waste per year, which is currently delivered to off-site landfills. NREL conducted an analysis to evaluate the economic viability of burning this waste in an on-site waste-to-energy facility in order to generate electricity. This action would produce renewable electricity for Fort Carson and reduce the burden on local landfills. Table 28 presents the results.

Table 28. Economic Analysis of Waste-to-Energy Plant

\begin{tabular}{|c|c|}
\hline \multicolumn{2}{|l|}{ Plant Characteristics } \\
\hline Annual MSW resource (tons/yr) & 8,778 \\
\hline Availability & $90 \%$ \\
\hline Capacity (tons/day) & 27 \\
\hline $\begin{array}{l}\text { Electric Generating Capacity } \\
\text { (kW/TPD) }\end{array}$ & 25 \\
\hline Electric Generating Capacity $(\mathrm{kW})$ & 670 \\
\hline Parasitic Load (\%) & $15 \%$ \\
\hline Net to Grid $(\mathrm{kW})$ & 570 \\
\hline Operating Hours (hr/day) & 24 \\
\hline \multicolumn{2}{|l|}{$\begin{array}{l}\text { Initial Cost } \\
\end{array}$} \\
\hline Capital Cost (\$) & $\$ 11,960,000$ \\
\hline Federal Tax Credit & $\$ 3,229,200$ \\
\hline Total Initial Cost & $\$ 8,730,800$ \\
\hline \multicolumn{2}{|l|}{ Revenues } \\
\hline Avoided Cost of Disposal (\$/ton) & 30 \\
\hline Annual Avoided Cost of Disposal (\$) & $\$ 263,340$ \\
\hline Electric Rate $(\$ / k W h)$ & 0.05 \\
\hline Annual Utility Savings & $\$ 224,694$ \\
\hline Recovered Materials (\%) & $3 \%$ \\
\hline Sale of Recovered Materials (\$/ton) & 175 \\
\hline $\begin{array}{l}\text { Annual Recovered Materials income } \\
\text { (\$) }\end{array}$ & $\$ 46,085$ \\
\hline Total Annual Revenues & $\$ 534,119$ \\
\hline \multicolumn{2}{|l|}{ Expenses } \\
\hline Operating Costs (\$/ton) & 131 \\
\hline Annual Operating Costs (\$) & $\$ 1,149,918$ \\
\hline Total Annual Expenses & $\$ 1,149,918$ \\
\hline \multicolumn{2}{|l|}{ Payback } \\
\hline Simple Payback & Negative \\
\hline
\end{tabular}

The NREL analysis shows that low tipping fees and relatively low electric rates make a WTE project uneconomical at Fort Carson. 
A larger WTE plant could improve the economics of the project. Relative labor costs for this project are high because running a plant requires a minimum number of employees. The plant analyzed requires 14 staff, which is similar to the number required for a plant five times its size. A larger plant would involve lower labor costs on a $\$ / \mathrm{MW}$ basis, but it would be necessary to import MSF fuel from off-base landfills. PNNL's 2008 study found that combining Fort Carson waste with the much larger waste stream (300,000-400,000 tons/years) from either the Fountain, Midway, or Colorado Springs landfills would fuel a 40-46 MW combustion plant with payback periods of seven to nine years (using 2008 utility rates).

\subsubsection{Recommendations}

The NREL analysis found that a WTE plant using only on-site waste would not be economically viable. If Fort Carson is interested in pursuing a WTE plant, we recommend assessing the feasibility of bringing off-site waste onto the post. A successful project would require a large amount of coordination and cooperation between the base and the cities of Fountain and Colorado Springs, both of which operate local landfills.

\subsection{Landfill Gas}

\subsubsection{Technology Overview}

Previously we discussed burning waste to generate energy. It is also possible, however, to generate energy through the anaerobic decomposition of carbon-based waste streams deposited in a landfill. This landfill gas is primarily composed of methane and carbon dioxide. Typically a gas handling system at the landfill traps, collects, and transports the gas produced. It is often necessary to clean up landfill gas prior to combustion in order to remove potentially hazardous compounds such as sulfur. Once a landfill is capped and closed off, it will continue to produce gas for 15-20 years.

A good candidate for landfill gas collection should have at least 1 million tons of waste in place, be at least 30 feet deep, and be active or recently closed. It should also have a high organic content, because non-organic waste does not break down and emit methane.

\subsubsection{Analysis}

Fort Carson has three closed MSW landfills and nine closed construction and demolition (C\&D) landfills on-site. The C\&D landfills are not appropriate for landfill gas collection because most of the waste is not organic. We found the MSW landfills to be too small, shallow, and old to produce landfill gas.

There are several larger active landfills in the area outside the base. NETL's alternative methane fuel resource database shows there are four landfills within a 15 mile radius. These facilities have an estimated total energy value of 793,873 MMBtu and estimated power potential of $12.52 \mathrm{MWe}$ (see Figure 27). These off-site landfills would not provide an on-site source of renewable energy. However, if landfill gas were generated at these sites and treated to reach pipeline quality, it could be placed in CSU's natural gas distribution network. Fort Carson could then utilize natural gas directly from the pipeline, but would be, in fact, purchasing the renewable landfill natural gas. This arrangement would provide a renewable fuel source for Fort Carson's boilers or future fuel cells or microturbines. 


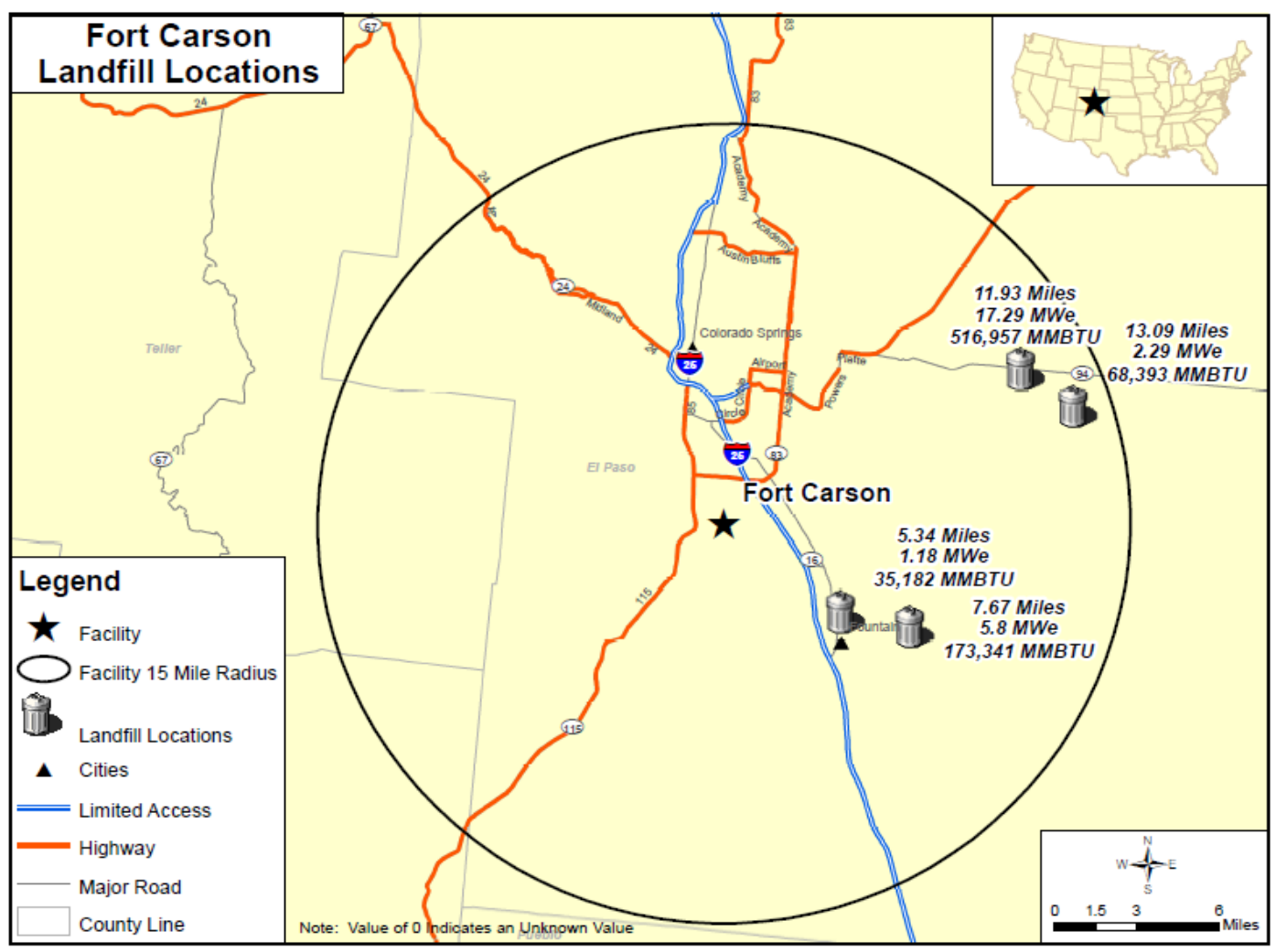

Figure 27. Landfills near Fort Carson (Credit: Craig Hustwit, ORNL)

PNNL's analysis ${ }^{15}$ suggests that these area landfills have very low moisture content and typically are not lined, indicating low methane generation, so collecting the gas and then piping it to Fort Carson may not be a viable option.

\subsubsection{Recommendations}

We recommend discussing offsite landfill gas generation projects with CSU and local landfill owners to evaluate whether local landfills are appropriate for landfill gas systems and if it is feasible to pipe gas to Fort Carson.

\subsection{Anaerobic Digestion}

\subsubsection{Technology Overview}

Anaerobic digestion is the conversion of wet biomass feedstocks such as confined animal waste, industrial effluent, or wastewater to methane fuel. Because of its high water content, it is not efficient to transport wet feedstocks. Instead, they must be converted on site where they are generated.

\footnotetext{
${ }^{15}$ Chvala, W.D.; Solana, A.E.; Sates, J.C.; Warwick, W.M.; Weimar, M.R., Reilly, R.W., and Dixon, D.R. Renewable Energy Opportunities at Fort Carson, Colorado. PNNL-18132. Pacific Northwest National Laboratory: December 2008.
} 


\subsubsection{Analysis}

Fort Carson's only on-site source of wet feedstock is a small wastewater treatment plant, which is too small to make an energy generation project worthwhile. There is a larger wastewater treatment plant in the city of Colorado Springs, five miles north of Fort Carson. With a flow of 30 million gallons per day, this plant could generate enough methane to produce about 27,803 $\mathrm{MMBtu} /$ year or $0.93 \mathrm{MWe}$. Like the landfill gas discussed earlier, it might be possible to treat this gas to pipeline quality, place it in CSU's natural gas distribution network, and have Fort Carson purchase it to displace conventional natural gas. This arrangement would provide a renewable fuel source for Fort Carson's boilers or future fuel cells or microturbines.

\subsubsection{Recommendations}

We recommend discussing offsite methane gas generation projects with CSU and the City of Colorado Springs.

\subsection{Hydropower}

There is a small dam on the east side of Fort Carson near Fountain, but it would only provide enough power for five homes, and therefore is not worth developing. No other hydro resources exist at the base.

\subsection{Additional Strategies to Reduce Load and Footprint 6.15.1 Purchase Renewable Energy Certificates (RECs)}

The purchase of offsets or credits could enable Fort Carson to achieve a 100\% renewably powered status. REC purchases are an alternative strategy, but would not contribute to energy security at the site.

\subsubsection{Demand Response}

An additional option that Fort Carson may want to consider for its facilities is undertaking demand response contracts with CSU. Demand response is the lowering of electrical load during peak usage. By signing up with CSU as a demand-response provider, Fort Carson would gain additional revenue to fund its energy projects and would receive free advanced metering infrastructure. Demand response should be a particularly intriguing strategy if Fort Carson has electrical loads that it can reduce during peak demand two to three times per year, or is able to utilize its backup generators during demand response events. 


\section{Transportation Assessment}

This section analyzes options for reducing fleet vehicle fuel consumption through vehicle replacement, fleet size reduction, or alternative fuel use.

\subsection{Fleet Composition and Fuel Use}

Fort Carson's fleet includes 520 vehicles, dominated by vans, SUVs, and pick-up trucks, as Table 29 shows.

Table 29. 2009 Fleet Summary by Vehicle Type and Fuel Type

\begin{tabular}{|l|r|r|r|r|r|r|}
\hline Vehicle Type & Gasoline & Diesel & E85 & CNG & Hybrid & Total \\
\hline Van & 83 & 3 & 50 & 29 & - & 165 \\
\hline SUV & 10 & - & 80 & - & 32 & 122 \\
\hline Pick-up & 51 & 24 & 38 & 11 & - & 124 \\
\hline Sedan & - & - & 21 & - & 6 & 27 \\
\hline Bus & - & 32 & - & - & - & 32 \\
\hline Heavy Truck & - & 11 & - & - & - & 11 \\
\hline Ambulance & - & 5 & - & - & - & 5 \\
\hline Other & 24 & 10 & - & - & - & 34 \\
\hline Total & 168 & 85 & 189 & 40 & 38 & 520 \\
\hline
\end{tabular}

The majority of the fleet uses traditional gasoline or diesel fuel, but a significant number of vehicles are flex fuel vehicles (FFVs) that can be fueled by E85. The remainder of the fleet is comprised of Compressed Natural Gas (CNG) and hybrid vehicles.

Fort Carson was unable to provide fleet fuel consumption data to NREL. Instead, we estimated 2009 fleet fuel use from the reported mileage of each vehicle and the vehicle class EPA mile per gallon rating (see Figure 28). Fort Carson personnel say E85 FFVs use E85 nearly exclusively, so we assumed that FFVs were always fueled by E85. The fleet uses approximately 276,500 gallons of fuel each year. 


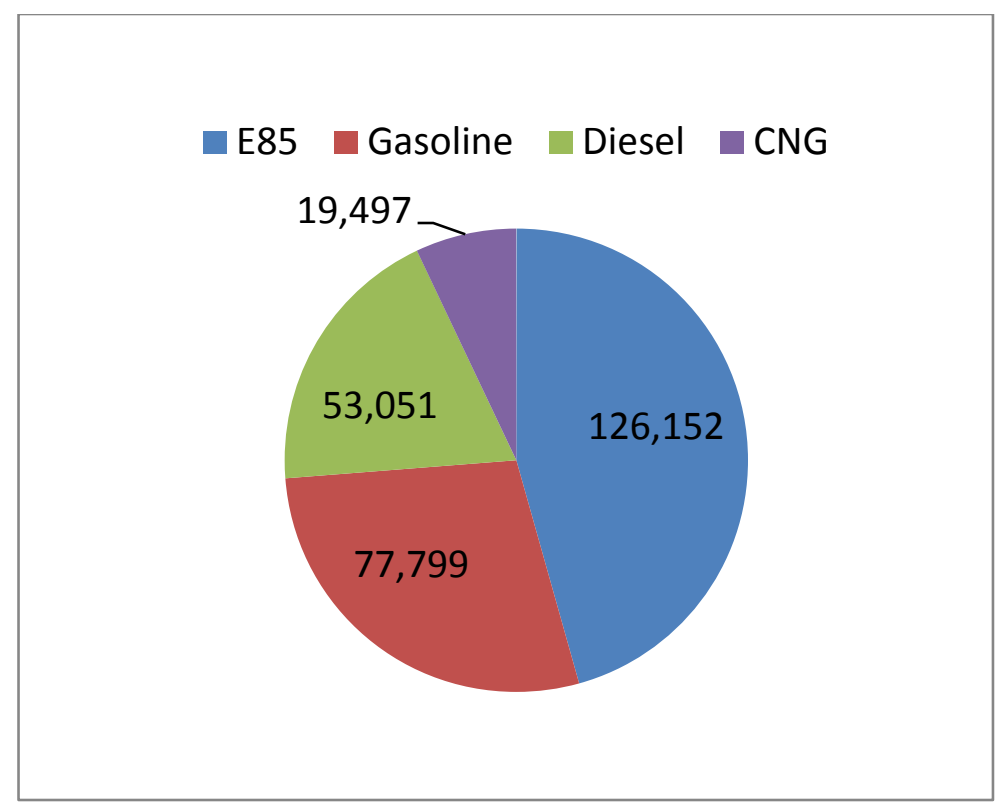

Figure 28. 2009 fleet fuel use estimates (gallons)

Given the relatively small number of sedans in the fleet, there may be an opportunity to downsize to smaller more fuel efficient vehicles and move away from large pick-ups and SUVs where the mission does not dictate a need for these larger vehicles. If there are instances where a vehicle is used primarily for passenger transportation, a small sedan may well meet the fleet needs. Moving from an older large truck to a compact sedan can halve fuel consumption for that vehicle. Likewise, moving from a large four-wheel drive SUV to a small two-wheel drive SUV can produce a significant efficiency gain.

Fort Carson possesses a significant number of Neighborhood Electric Vehicles (NEVs) that are not captured in the fleet inventory. The NEVs at Fort Carson represent an opportunity for reducing fleet fuel use, but their success has been limited by significant constraints compared to a traditional vehicle. NEVs have a maximum speed typically of 25 miles per hour, which can be viewed as too slow on major roads. The vehicles do not have the comforts of climate control or the ability to handle severe road conditions. Even with these constraints, NEVs are recommended for campus settings where the distance traveled is small, when traffic is light, and when weather conditions are not severe. If NEVs are used in targeted settings they can provide significant petroleum displacement.

\subsection{Fleet Utilization Rates}

The Fort Carson fleet includes a large number of underutilized vehicles as Figure 29 shows. Suggested standard minimum utilization rates for federal fleets range from 7,500 to 12,000 miles per year, depending on vehicle classes. Fort Carson has received a waiver from the Department of the Army to use reduced utilization rates of 300 miles a month or 3,600 miles per year, due to the specific mission needs of the installation. However, one-third $(33 \%)$ of the vehicles in the Fort Carson fleet in 2009 appear to have driven less than the reduced 3,600 mile annual rate. 


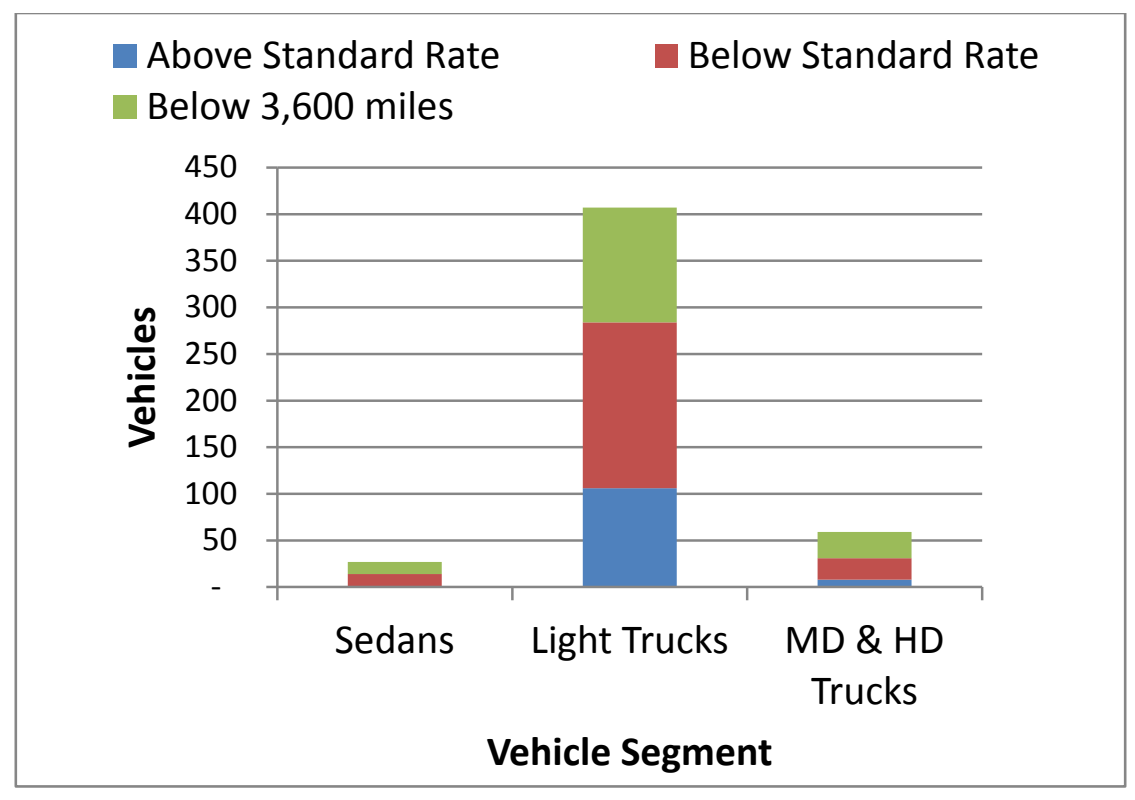

Figure 29. 2009 vehicle utilization

Fort Carson vehicles have low mileage due to infrequent use or short driving distances. In some instances, a vehicle may be required to support an infrequent highly important mission such as emergency response. In other cases, individual organizations may have an assigned vehicle that is infrequently used. In these cases a vehicle pool available across organizations may provide the necessary transportation access for all organizations, with fewer total assets. NREL has learned that Fort Carson has had some success with this model, and further opportunities for efficiencies through vehicle pools may exist.

Fort Carson primarily leases its fleet vehicles from GSA and they carry a significant monthly lease cost. Reducing the number of vehicles in the fleet might free up budget dollars for other fleet needs. As an example, a preliminary analysis of vehicles that could be up for replacement by GSA in the current year showed that 44 vehicles representing nearly $\$ 150,000$ in annual lease costs were driven less than 300 miles a month. If these vehicles were turned in and not replaced, the fleet could free up money to support other initiates, such as implementing alternative fuel infrastructure or an electric vehicle pilot program.

The Fort Carson fleet has a sizeable number of alternative fuel vehicles (AFVs) dominated by E85 FFVs, but which also includes a number of CNG and hybrid electric vehicles. NREL was informed that the installation has been successful in consistently fueling its FFVs with E85 available at on-site fueling centers. Without accurate fuel use data, it is not possible to know for sure, or to track progress, but the FFVs represent a significant opportunity to reduce petroleum consumption. For the purposes of associated mandates, E85 is considered a 100 percent alternative fuel, and therefore vehicles fueled by E85 represent a 100\% petroleum displacement.

The CNG vehicles in the fleet are late in their lease term and may be up for replacement soon. It was not clear whether or not $\mathrm{CNG}$ is readily available to fleet vehicles. If CNG is available it 
represents a good opportunity for petroleum displacement, particularly in medium and heavy duty applications.

Fleet HEV acquisitions have risen in recent years. Depending on how the HEVs are used, the associated petroleum displacement can vary. If the HEV is driven at low speeds the efficiency gains are higher than if the vehicle is used more for highway driving. While HEVs use less petroleum than a traditional vehicle, they are fueled by petroleum are more expensive than traditional vehicles. Other AFV technologies can reach larger petroleum displacements at a lower cost.

The fleet also contains a sizeable number of diesel vehicles focused in larger medium and heavy duty applications. These vehicles represent an opportunity to implement a biodiesel program on the installation or in coordination with the surrounding community.

\subsection{Recommendations}

The NREL assessment produced the following recommendations:

- Track fleet fuel use. As mentioned, our analytic team did not receive data on Fort Carson's non-tactical fleet fuel, which presumably the base does not track or manage. This circumstance is problematic for a variety of reasons, including the requirement of the Army annually to report progress in meeting statutory mandates for the increased use of alternative fuel and the reduction of petroleum use. An internal fuel use tracking and reporting audit at Fort Carson would be beneficial, and would establish ownership of fuel use data management responsibilities. At a minimum, for purposes of meeting the mandates, the fleet should track the annual total gallons of each fuel type used per vehicle. Higher levels of detail would then improve the ability of the fleet to analyze and manage fuel use.

- Right-size the fleet. Fort Carson appears to have an opportunity to reduce the total number of vehicles in the fleet. During the annual lease vehicle ordering process, low-use vehicles should not be replaced. The base could then allocate the significant annual budget dollars saved from not leasing a vehicle to other fleet needs. A vehicle pool available across organizations can more efficiently meet the needs of the fleet with fewer total vehicles.

- Base managers should align the vehicle fleet composition to the mission of each vehicle. During the annual lease vehicle order process, the vehicle of choice should be the most fuel efficient vehicle to meet the mission needs. If passenger transportation is the primary mission, managers should consider fuel efficient sedans and vans. They should consider NEVs in targeted settings, particularly where travel distances are small. They should consider large SUVs and pick-ups only when the mission requires their capabilities. More fuel efficient two-wheel drive options with the same cargo capacity as four-wheel drive options should first be considered when missions do not include off-road driving. The base can achieve significant reductions in petroleum consumption by using the most fuel efficient vehicle for the mission. 
- Acquire alternative fuel vehicles. Fort Carson is fortunate to have E85 available on the installation. The fleet has been aggressive in expanding its use of E85 and should continue this practice. As vehicles are cycled through the lease process, base managers should continue to consider FFVs as replacements. Many of the current gasoline and diesel vehicles in the fleet could have FFV alternatives available during the ordering process. If $\mathrm{CNG}$ is available to the fleet, the base should continue to use it. CNG vehicles may be particularly successful when considering replacements for medium and heavy duty applications.

- Use alternative fuel. Operating FFVs provides an opportunity to reduce petroleum consumption. The fleet should take advantage of this opportunity by fueling FFVs with E85 every time the vehicles are fueled.

- The fleet should consider a biodiesel program for the diesel vehicles on post. Typically biodiesel is used in the form of B20, a blend of $20 \%$ pure biodiesel with $80 \%$ traditional petroleum diesel. Yet, vehicles that use biodiesel should run biodiesel $100 \%$ of the time, and fuel storage tanks must be cleaned prior to storing biodiesel. Biodiesel specs are in place to ensure a certain quality of biodiesel fuel. The DoD and the Marine Corps in particular have had great success with biodiesel fuel use. Fort Carson should be able to attain similar successes.

- Nearly half of the Fort Carson fleet uses traditional gasoline or diesel, consuming an estimated 130,000 gallons of petroleum annually. Not all traditional petroleum vehicles have an available E85 FFV as a replacement, but it is not unreasonable to expect that half of the remaining gasoline vehicles could be replaced by a FFV. Consistently fueling these new FFVs with E85 would displace nearly 40,000 gallons of gasoline consumption. Consistently using biodiesel in the diesel vehicle fleet would displace another 10,000 gallons of petroleum. This scenario could far exceed federal mandates to reduce petroleum use $30 \%$ by 2020 from a 2005 baseline.

- Hybrids and electric vehicles. HEVs should be primarily considered for those instances where other AFV technologies are not available to meet the mission. HEVs do reduce petroleum consumption, but other AFV technologies have the potential for a much larger petroleum displacement at a lower cost.

- Electric vehicles are beginning to be available to fleets and represent an opportunity for a $100 \%$ petroleum displacement. These vehicles do have limitations, including a limited range and potentially lengthy recharging times. Fort Carson should target specific applications that account for these limitations if the technology is to have the most success (see Appendix A for additional detail regarding the use and infrastructure requirements of electric vehicles).

\subsection{Other Transportation Energy}

Fuel for the Federal fleet makes up only a small portion of transportation energy used at Fort Carson. Figure 30 shows that tactical fuel and commuter fuel use actually account for most of the base's transportation fuel use. 


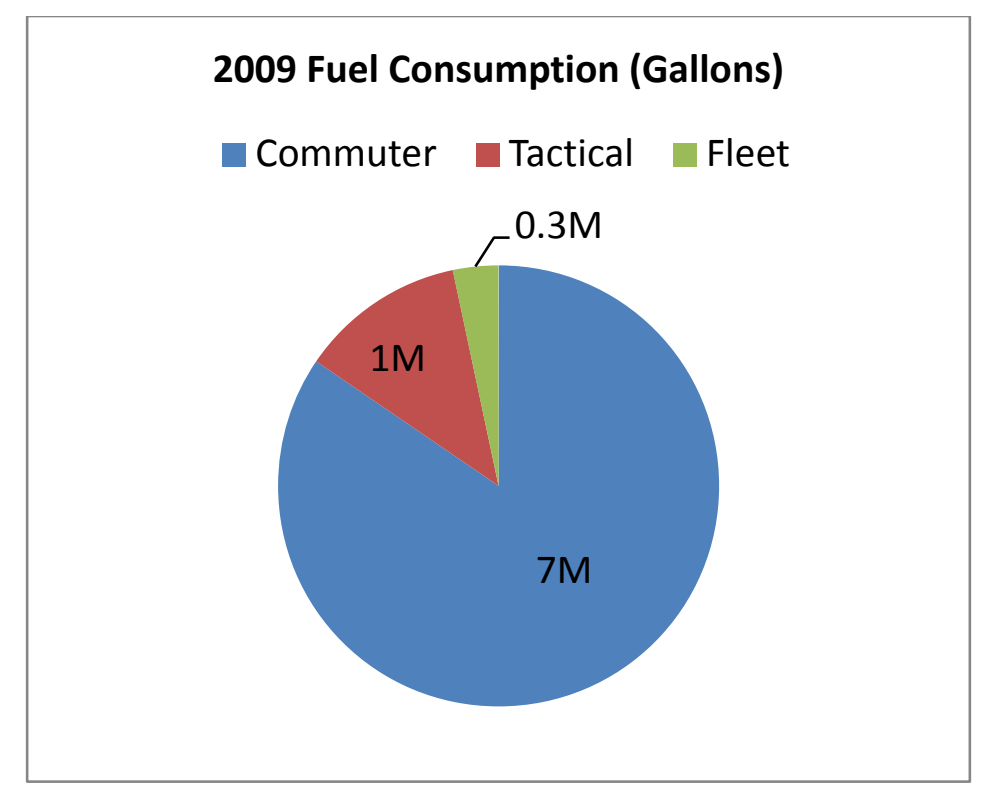

Figure 30. 2009 Fort Carson fuel use estimates by segment

Examination of these fuel uses was out of the scope of the NZEI analysis; however, we provide a few suggestions below for potentially reducing fuel use from these sources.

\subsubsection{Commuter Fuel Use}

NREL estimates Fort Carson commuter fuel use to be 7 million gallons of gas annually. We base this estimate on assumptions of 28,000 commuters driving an average of 10 miles one way to the installation at an average efficiency of 20 miles per gallon for 250 days. Even with sizeable fluctuations in assumptions, commuter fuel use at Fort Carson dwarfs fleet fuel use. Reducing commuter fuel use by 5\% would displace 350,000 gallons of petroleum, which would more than exceed the amount of fuel used by the fleet.

NREL did not investigate whether or not Fort Carson has an initiative in place to reduce commuter fuel use. If commuter fuel reduction policies are in place, the recommendations to follow may be redundant. (See Appendix A for additional information regarding the impact of electric vehicle adoption on commuter trends.)

- Alternative work schedules/locations. Alternative work schedules may allow commuters an option to take every other Friday off or work from home one day a week. The alternative schedules would reduce the number of commuter trips and thus reduce petroleum consumption.

- Ride sharing. A formal ride sharing program may help to maximize the number of commuters participating. One approach is to e-mail all employees asking for volunteers of who might be interested in sharing rides to and from work. Interested parties would provide their address information, and would be matched with other personnel living nearby. 
- Idle reduction. The large number of daily commuters to Fort Carson may create long wait times at the entrance gates. Allowing for staggered employee daily start times could reduce the congestion and the need for commuter vehicles to idle at the gates.

\subsubsection{Tactical Fuel Use}

The tactical fuel use represents a significant portion of all transportation fuel used at Fort Carson. We recommend that NREL conduct additional analysis on the potential for reduced tactical fuel use based on efficiencies. NREL has supported DoD extensively in the past, and understands the unique challenges and opportunities faced by the military services. We would welcome the opportunity to work with DoD personnel in identifying potential operational efficiencies, and in lobbying for additional support for the military when it is clear that the services are underresourced. 


\section{Microgrid Assessment and Recommendations}

While the majority of this report focuses on opportunities for achieving a net zero installation tied to the utility grid, at times the utility grid may become unavailable. When this happens, the military base must provide backup power to its own critical loads. If utility service is lost for a significant amount of time, it may be desirable to operate Fort Carson as a self-contained distribution system known as a microgrid. Operating as a microgrid requires extensive planning, and equipment must be specially configured to operate correctly in the absence of the utility grid. In coordination with this study, Sandia National Laboratory (SNL) is evaluating microgrid design options. Traditionally, microgrid emergency back-up systems consist of a set of dispatchable, fossil-fuel driven generation sources, such as diesel generators. This analysis looks at the benefits of using the renewable energy sources at Fort Carson to complement or replace a diesel generator backup system.

\subsection{Critical Load Profile}

Fort Carson worked with SNL to identify its critical mission facilities, and subdivided them into principal and secondary buildings. Designated facilities primarily included headquarters and communication buildings. The hospital and wastewater treatment plant, which are also considered critical, were not included in this analysis because their location makes it impractical to tie them into the microgrid. The critical load in the primary and secondary buildings was estimated based on existing backup generator capacity at each building, as Table 30 shows.

Table 30. Critical Load

\begin{tabular}{|c|c|}
\hline Building & $\begin{array}{r}\text { Diesel Backup } \\
\text { Generator } \\
\text { Size (kW) } \\
\end{array}$ \\
\hline \multicolumn{2}{|c|}{ Principal Critical Loads } \\
\hline Bld. 1014 & 160 \\
\hline Bld. 1118 & 475 \\
\hline Bld. 1430 & 500 \\
\hline Bld. 1435 & 1,250 \\
\hline Bld. 1550 & 1,000 \\
\hline \multicolumn{2}{|c|}{ Secondary Critical Loads } \\
\hline Bld. 1525 & 50 \\
\hline Bld. 1444,1526 , and 1829 & 0 \\
\hline \multicolumn{2}{|l|}{$\begin{array}{ll}\text { Total } \\
\end{array}$} \\
\hline $\begin{array}{l}\text { Peak Critical Load } \\
\text { Primary + Secondary }\end{array}$ & 3.0-4.0 MW \\
\hline
\end{tabular}

We used the original load profile to model the critical load profile. Since the original load profile included energy generation from the 2 MW PV array, we added the hourly solar PV production back into the base load. We then scaled down this profile to have a peak critical load equal to the critical primary and seconday peak loads. 


\subsection{Model Assumptions}

NREL used the HOMER modeling tool to optimize energy sources for the microgrid, including the following power generation sources in the optimization:

- Diesel Generator

- Three diesel $1 \mathrm{MW}-1250 \mathrm{kVA}$ Caterpillar gensets are modeled to provide backup power. Figure 31 shows the genset efficiency curve.

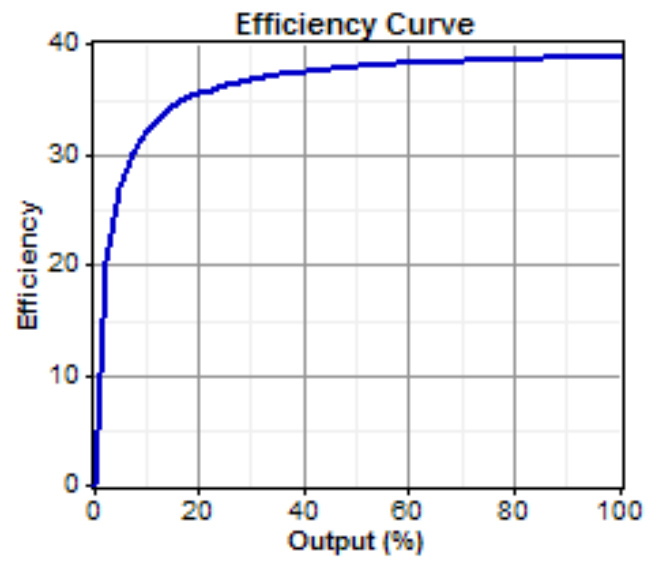

Figure 31. Genset fuel efficiency curve

- The average efficiency is approximately $38 \%$. The minimum allowable load on the generator was set to $10 \%$ of its rated capacity, as a conservative estimate. This means that if the load falls below $10 \%$ of the rated capacity, the generators will continue to run at the minimum rate. If $\mathrm{PV}$ and/or batteries are able to meet the entire critical load, the generators will shut off.

- Fuel Cost. According to the U.S. Government's Energy Information Administration ${ }^{16}$ the average price for diesel is $\$ 2.85 /$ gal ( $\$ 0.75 /$ liter).

- Capital and O\&M cost. The capital cost used in the model is $\$ 400 / \mathrm{kW}$ for a total capital cost of approximately $\$ 1,200,000$ for the $3 \mathrm{MW}$ generation.

Maintenance cost is estimated to be $\$ 8.53$ /hour and is dependent on the hours of operation and the percentage of full load that it serves.

- Flow Battery. Flow batteries (utility scale rechargeable batteries that use electrolytes for converting stored chemical energy into electricity) reduce the use of diesel and store the energy from the PV and wind. We modeled the ZBB energy corporation flow battery in HOMER with a capital cost of $\$ 100,000$. The nominal capacity is 500 Ah with round trip efficiency of $72 \%$. The life time of the flow battery is 30 years; the cell stack lifetime is 10 years.

- Hybrid Electric Vehicles (HEV) Battery. HEV batteries can also provide storage on the microgrid. The HEV module designed for this analysis represents a bank of batteries distributed across 20 all-electric trucks slated to become part of the Fort

\footnotetext{
${ }^{16}$ Energy Information Administration. Official Energy Statistics from the U.S Government Site. Weekly Retail OnHighway Diesel Prices ,http://tonto.eia.doe.gov/oog/info/wohdp/diesel.asp. Accessed April 2010.
} 
Carson Transportation Motor Pool. These are modeled after the Smith Electric Vehicle "Newton," ${ }^{17}$ each having an $80 \mathrm{kWh}$ battery pack with the capability of charging (and potentially discharging) at $20 \mathrm{~kW}$. Based on recent information gathered by NREL, we assumed a battery cost of $\$ 1,000 / \mathrm{kWh}$ for a stationary battery system (without the vehicle).

- Battery performance is modeled by cycle life and charge efficiency. We estimated cycle life from Brooker, 2010, ${ }^{18}$ assuming approximately 20,000 cycle at $10 \%$ depth of discharge and 2000 cycles at $50 \%$ depth of discharge. We based the charge efficiency on the internal impedance data from Keyser, 2003. ${ }^{19}$

- PV. We modeled the capital cost of PV at $\$ 6.00 / \mathrm{W}$ for capital cost and replacement. We assumed a lifetime of 25 years for the array.

- Wind. We modeled 1.5 MW wind turbines with a capital and replacement cost of $\$ 5$ million/turbine. This cost decreases to $\$ 4$ million/turbine as the number of turbines increase; thus, for 20 turbines, the cost would be $\$ 80$ million. The O\&M cost is $\$ 108,000 /$ year. The expected lifetime of a wind turbine is 15 years. Note that we used the lower wind resource near the microgrid area on the north end of base for this scenario.

- Biomass. The biomass generator has a capital cost and replacement cost of $\$ 8.75$ million per MW. The non-fuel O\&M cost is $\$ 446 /$ hour. We assumed the lifetime of the generator to be 200,000 hours. The boiler associated with the biomass system has an efficiency of $70 \%$. Electrical efficiency is $20 \%$. Natural gas costs $\$ 5.44 / \mathrm{MMBtu}$ and the woody biomass fuel costs $\$ 55 /$ ton or $\$ 4.50 / \mathrm{MMBtu}$.

\subsection{Results}

If only diesel generators were used to support the critical loads, $4.3 \mathrm{MW}$ of diesel generation would be required, with a COE of $\$ 0.25 / \mathrm{kWh}$. This scenario would use an estimated 1,755,552 gallons per year of diesel fuel. The optimal solution to meet the critical loads on an islanded system is $3.1 \mathrm{MW}$ of biomass, $1 \mathrm{MW}$ of diesel generation, and $500 \mathrm{~kW}$ of PV, as Table 31 shows. When biomass and PV replace some of the diesel generation, the COE decreases to $\$ 0.17 / \mathrm{kWh}$ and diesel fuel use drops $93 \%$ to 110,258 gallons annually.

\footnotetext{
${ }^{17}$ www.smithelectric.com/

${ }^{18}$ Brooker, A.; Thornton, M.; Rugh, J. Technology Improvement Pathways to Cost Effective Vehicle Electrification: Preprint. NREL, 2010

${ }^{19}$ Keyser, M.; Pesaran, A.; Mihalic, M.; Yu, J.; Kim, S.; Alamgir, M.; Rivers, D. Thermal Characterization of Advanced Lithium-Ion Polymer Cells. Advanced Automotive Battery Conference, June 2003.
} 
Table 31. Energy Mix to Meet the Critical Load

\begin{tabular}{|l|r|r|r|}
\hline Component & Size (MW) & Production (kWh/yr) & Production (\%) \\
\hline Biomass & 3.1 & $23,349,642$ & 91 \\
\hline Diesel Generator & 1.0 & $1,552,869$ & 6 \\
\hline PV array & 0.5 & 778,655 & 3 \\
\hline Total & & $25,681,166$ & 100 \\
\hline
\end{tabular}

Figure 32 shows the monthly power production for the microgrid system.

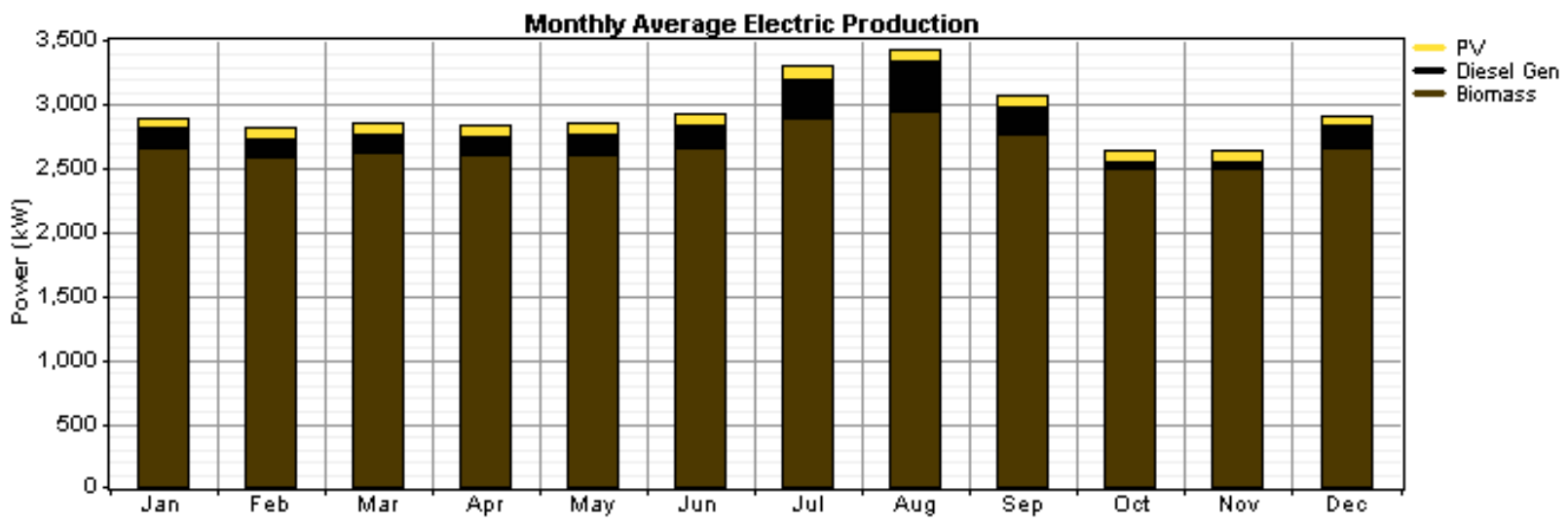

Figure 32. Monthly power production for microgrid

Because the microgrid cannot rely on the utility grid as a source or sink for excess power, the load and generation must match exactly at all times. While PV and wind were the most costeffective sources of renewable energy in the grid-tied case, their high variability makes them less effective on a microgrid. Consistent baseload sources of power, like diesel generation, biomass, or CSP are better choices in a microgrid scenario despite their higher cost.

The Fort Carson microgrid modeled here relies mainly on biomass as the cheapest source of baseload power. Diesel generation supplements the biomass generator, and provides added security in case biomass fuel supplies are disrupted. Other options for consistent power, such as flow batteries and HEV batteries are not part of the solution, due to their high cost compared to diesel or biomass fuel. A small amount of PV offsets some biomass and diesel fuel but, due to the variability of $\mathrm{PV}$ generation, only a small amount can be incorporated in the microgrid while maintaining stability. Wind is no longer part of the solution because the wind resource near the microgrid area is poor.

This solution requires a large amount of biomass fuel that will have to be trucked in from offsite. In a long term utility outage, transportation pathways might be disrupted. To reduce reliance on 
outside fuel sources like biomass and diesel, PV or CSP could support the microgrid. The base could use diesel backup generators to generate power during extended cloudy periods.

\subsection{Recommendations}

If a microgrid at Fort Carson is desired, we recommend a detailed study to determine equipment requirements. The above analysis is intended to illustrate the potential benefits of incorporating renewable energy sources into a microgrid at Fort Carson. Base personnel should not consider it sufficient for microgrid planning and operation.

In addition to the recommended electrical system studies, implementing a microgrid with renewable energy, storage, and generators at Fort Carson will require the addition of "smart" controls. These controls would allow Fort Carson to manage its distributed resources and intentionally island itself from Colorado Springs Utility, in order to ensure the ability to continue critical operations during an extended emergency. The sophisticated control system would coordinate the electrical generation systems (renewable, storage, and diesel generators) and Fort Carson's critical loads to maintain grid stability. Additionally, the smart control system will allow safe reconnection with the utility once the emergency condition has passed.

In addition to allowing operation as a stand-alone island, the control system would potentially allow Fort Carson to participate in local grid support activities such as customer demand response. The base might, for example, coordinate adjustable loads such as the charging of fleet electric vehicles with CSU in order to ensure that the local grid is not taxed beyond its capabilities as the nature of distribution systems and their uses evolve in the future. A control system may also interface with building energy management systems to increase the efficiency of the distribution system by improving renewable generation and load coincidence.

The microgrid control system would consist of a central computer system that would receive data from a network of sensors strategically placed on critical base infrastructure. The system would need high-resolution load monitoring capability and the ability to follow load by dispatching generation or rapidly turning on and off generation systems. Additionally, the system would require real-time voltage, current, and frequency measurements to ensure the microgrid operates within criteria.

Recommended studies for microgrid planning and operation include:

- Voltage regulation

- Protection and coordination

- Voltage stability

- Rotor-angle stability

- Frequency regulation.

All studies should use actual machine and system parameters and settings. It is important to consider and account for impact on system O\&M when designing and implementing a microgrid. 


\section{Energy Project Recommendations}

The overall goal of this assessment is to recommend an optimal energy project strategy that will support the installation's energy goals. Here, we provide two sets of recommendations: 1) currently cost-effective projects, and 2) projects to achieve net zero energy.

\subsection{Currently Cost-Effective Energy Projects}

Our analysis found that, based on 2009 energy prices, the following projects would reduce the life cycle cost of energy. Implementing these projects would reduce site energy use from 2009 levels by $30 \%$ and source energy use by $33 \%$.

Table 32. Cost-Effective Energy Projects

\begin{tabular}{|c|c|c|c|c|c|}
\hline Technology & Size & $\begin{array}{r}\text { Site Energy } \\
\text { Savings } \\
\text { (MMBtu) }\end{array}$ & $\begin{array}{r}\text { Source } \\
\text { Energy } \\
\text { Savings } \\
\text { (MMBtu) }\end{array}$ & $\begin{array}{r}\text { Implementation } \\
\text { Cost (\$) } \\
\end{array}$ & $\begin{array}{r}\text { Simple } \\
\text { Payback } \\
\text { Period } \\
\text { (years) }\end{array}$ \\
\hline $\begin{array}{l}\text { Energy } \\
\text { Efficiency } \\
\end{array}$ & $20.3 \%$ & 345,337 & 632,240 & $45,356,563$ & 14 \\
\hline $\begin{array}{l}\text { Solar } \\
\text { Ventilation } \\
\text { Preheating } \\
\end{array}$ & $\begin{array}{r}88,050 \\
\mathrm{ft}^{2}\end{array}$ & 26,353 & 28,777 & $2,241,277$ & 15 \\
\hline GSHP & $\begin{array}{r}1,633 \\
\text { tons }\end{array}$ & 34,055 & 16,061 & $1,138,477^{\mathrm{a}}$ & 16 \\
\hline Wind & $\begin{array}{l}10.5 \\
\text { MW }\end{array}$ & 61,304 & 171,528 & $13,656,300$ & 16 \\
\hline Total & - & 455,285 & 856,887 & $62,392,617$ & 15 \\
\hline
\end{tabular}

a. Includes avoided cost of conventional heat system replacement

If appropriated funds are not available, we recommend energy load reduction measures including energy efficiency, GSHP, and solar ventilation preheating projects, which the base would implement through an ESPC or UESC contract. We recommend implementation of the wind project through a power purchase agreement.

\subsection{Net Zero Energy Projects}

To achieve net zero energy status, Fort Carson will need to implement additional energy projects. Table 33 shows the projects we recommend in order to achieve near net zero energy use by 2015 . Fort Carson expects growth in energy use to level off by 2015 as new building construction ends, so we anticipate that these projects will provide enough energy to achieve near net zero energy status in 2015 and beyond. 
Table 33. Recommended Projects to Achieve Near Net Zero Energy In 2015

\begin{tabular}{|c|c|c|}
\hline & $\begin{array}{r}\text { Size } \\
\text { (Variable Units) } \\
\end{array}$ & $\begin{array}{r}\text { Site Energy } \\
\text { (MMBtu) }\end{array}$ \\
\hline \multicolumn{3}{|c|}{ Electric Energy Project Recommendations } \\
\hline Efficiency & $26.70 \%$ & 203,388 \\
\hline Wind & $10.5 \mathrm{MW}$ & 61,304 \\
\hline PV-ground mount ${ }^{\mathrm{a}}$ & $20.2 \mathrm{MW}$ & 100,554 \\
\hline PV-rooftop & $24 \mathrm{MW}$ & 125,580 \\
\hline PV-carport & 28.4 MW & 120,046 \\
\hline CSP & $20 \mathrm{MW}$ & 170,600 \\
\hline $\begin{array}{l}\text { Total Renewable Electricity } \\
\text { Production (MMBtu) } \\
\end{array}$ & & 781,472 \\
\hline 2015 Electricity Use (MMBtu) & & 781,472 \\
\hline $\begin{array}{l}\text { Percent of electric energy } \\
\text { supplied by renewables }\end{array}$ & & $100 \%$ \\
\hline \multicolumn{3}{|c|}{ Thermal Energy Project Recommendations } \\
\hline Efficiency & $17.20 \%$ & 266,270 \\
\hline Solar Vent Preheat & 119,748 & 35,841 \\
\hline Solar Hot Water & 59,080 & 28,406 \\
\hline Biomass Heat & $30 \mathrm{MMBtu} / \mathrm{hr}$ & 160,000 \\
\hline GSHP & 24,684 & 514,611 \\
\hline $\begin{array}{l}\text { Total Renewable Thermal } \\
\text { Production (MMBtu) } \\
\end{array}$ & & $1,005,128$ \\
\hline $\begin{array}{l}2015 \text { Thermal Energy Use } \\
\text { (MMBtu) }\end{array}$ & & $1,143,335$ \\
\hline $\begin{array}{l}\text { Percent of thermal energy } \\
\text { supplied by renewables }\end{array}$ & & $88 \%$ \\
\hline \multicolumn{3}{|c|}{ Transportation Energy Project Recommendations } \\
\hline $\begin{array}{l}\text { Replace half of gasoline- fueled } \\
\text { vehicles with E85 }\end{array}$ & 40,000 & 4,400 \\
\hline Replace diesel with biodiesel & 10,000 & 1,380 \\
\hline $\begin{array}{l}\text { Continue current renewable } \\
\text { fuel use }\end{array}$ & 126,152 & 11,089 \\
\hline Total Renewable Fuel Use & 176,152 & 16,869 \\
\hline Total Fuel Use & 276499 & 29403 \\
\hline $\begin{array}{l}\text { Percent of fleet energy supplied } \\
\text { by renewables }\end{array}$ & & $57 \%$ \\
\hline
\end{tabular}

a. $2 \mathrm{MW}$ of the required 20.2 MW is already installed at Fort Carson 
Figure 33 shows Fort Carson energy sources if recommendations are implemented.

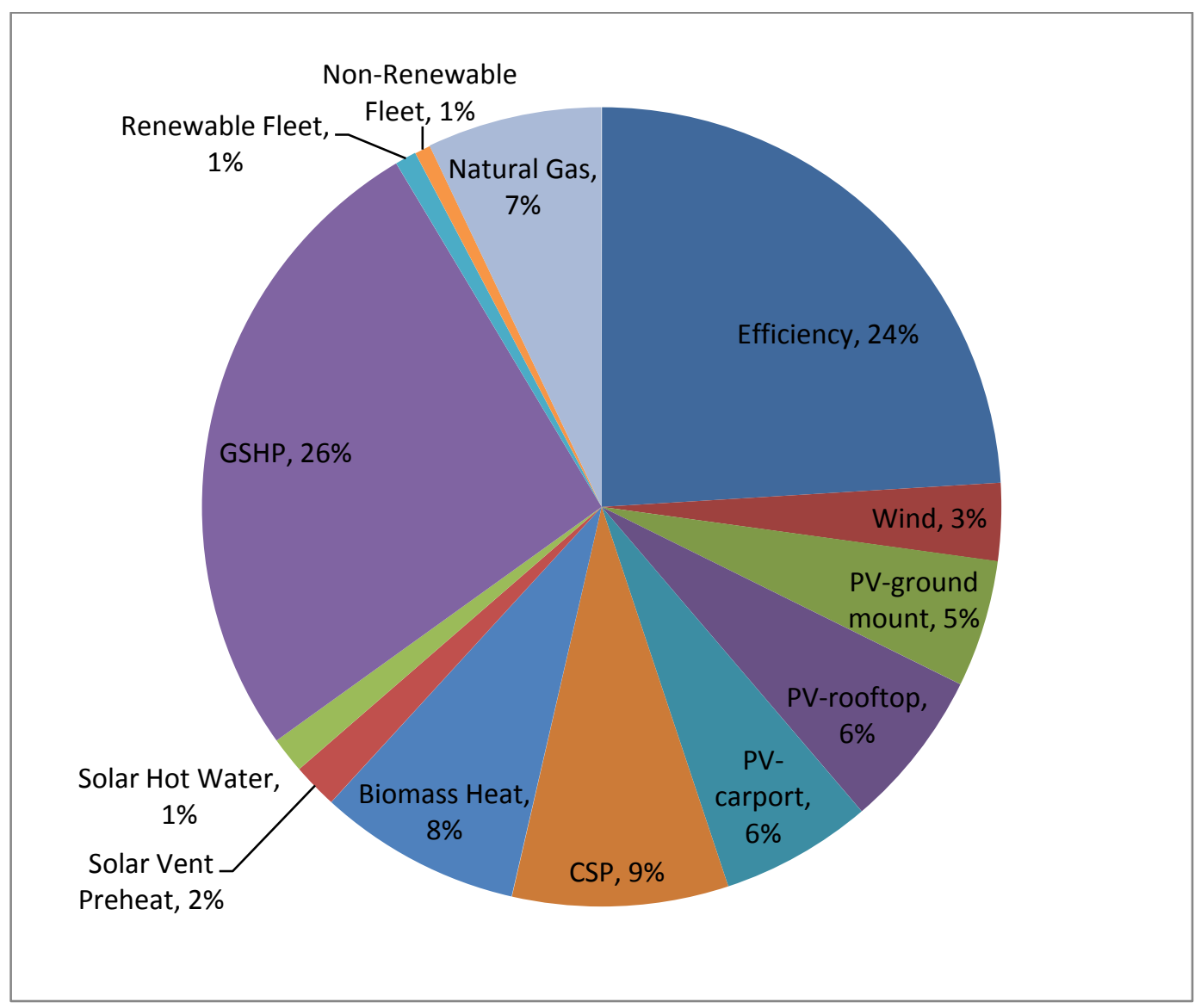

Figure 33. 2015 energy mix

\subsubsection{Electrical Energy}

The NREL analysis calls for first reducing electrical energy use through efficiency, using the measures outlined in Section 5. To extrapolate efficiency savings to 2015, we assume that efficiency reductions implemented in new buildings are equal to efficiency reductions in existing buildings. The base would generate remaining electrical energy through a combination of wind, $\mathrm{PV}$, and CSP. Our analysis added technologies to the mix in order of economic viability, with size limited by land and resource constraints. Our analysis limits wind capacity to $10.5 \mathrm{MW}$ based on land available in the high wind area. Ground mount PV and rooftop PV capacity are limited based on our assessment of available ground and rooftop area. CSP capacity is also limited by land availability. 
This analysis did not evaluate the effects of large scale renewable generation on Fort Carson's distribution system. If Fort Carson chooses to pursue installation of large renewable systems, staff should analyze the location and tie in point to the distribution systems and perform a detailed electrical analysis. This analysis should include vendor specific information such as machine impedances, controller modes and settings, and protective devices and set-points. The analysis should include the following:

- Voltage regulation

- Protection and coordination

- Voltage stability.

As generation is added to the distribution system, the entire base protection scheme must be continually evaluated to ensure proper operation. The distribution protection and coordination scheme must be able detect and compensate for the variability of the proposed generation sources.

\subsubsection{Thermal Energy}

The use of thermal energy is first reduced through efficiency, using the measures outlined in Section 5. Remaining requirements for thermal energy would be generated through a combination of solar ventilation preheating, solar water heating, ground source heat pumps, biomass, and natural gas. To extrapolate to 2015, we assume that savings from efficiency reductions and thermal building technologies (solar vent preheat, solar water heat, GSHP) are proportional to the savings estimated for existing buildings.

Our analysis shows that natural gas will remain part of the thermal energy solution, preventing Fort Carson from reaching $100 \%$ renewable energy. This outcome is primarily due to the difficulty of offsetting $100 \%$ of heating energy in distributed building systems with renewable energy. Options for meeting the remaining thermal energy use with renewable energy include:

- Install microturbines or fuel cells to heat individual buildings. In order for microturbines or fuel cells to be renewable, Fort Carson would need to use a renewable fuel, such as biogas from a landfill or wastewater treatment plant. We are not aware, however, of any sources of biogas currently available in Colorado Springs, although sources may be developed in the future.

- Expand the central heating system. Expanding the central heating system would allow additional thermal needs to be met through a renewable-fueled centralized system. Two options are a larger biomass boiler (subject to resource constraints) or a larger concentrating solar power system (subject to land availability).

- Convert to electric heating. The base could supply electric heating energy through additional roof-mounted or carport photovoltaics. 


\subsubsection{Transportation Energy}

Fuel use estimates suggest that if the fleet were to follow the recommendations to convert half of the gasoline vehicles to flex fuel vehicles and to implement a biodiesel program, the base could see a reduction of roughly 40,000 gallons of gasoline and 10,000 gallons of diesel. Figure 34 shows the recommended fuel use breakdown in gallons for the Fort Carson fleet.

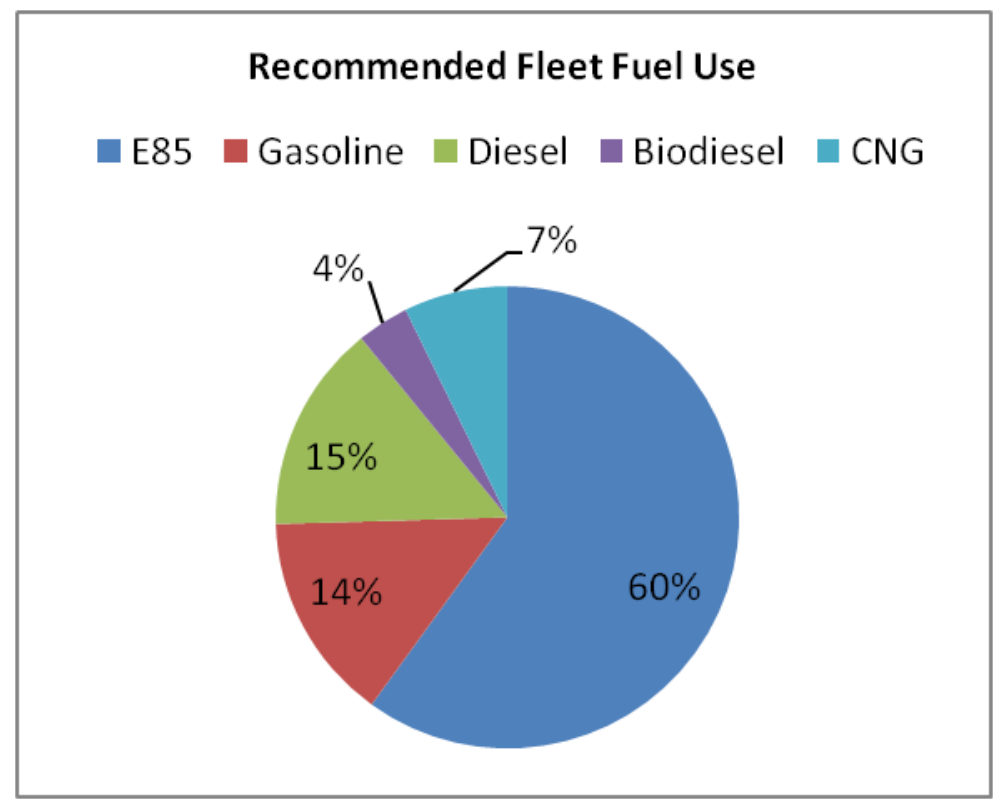

Figure 34. Fort Carson recommended fuel use breakdown

For renewable fuel accounting purposes, E85 is considered by the Federal Government as a $100 \%$ renewable fuel and B20 biodiesel and as a $20 \%$ renewable fuel.

These recommendations increase fleet renewable fuel use from $38 \%$ to $57 \%$. 


\section{Implementation: Project Planning and Financial Assessment}

\subsection{Implementation Options}

Fort Carson has a variety of available options for implementing the recommended energy projects. The following paragraphs describe these options (note: information on financing mechanisms adapted directly from www.femp.energy.gov/financing/mechanisms.html)

\subsubsection{Energy Savings Performance Contract (ESPC)}

ESPCs enable Federal agencies to accomplish energy-savings projects without up-front capital costs and without special Congressional appropriations.

An ESPC is a partnership between a Federal agency and an energy service company (ESCO). The ESCO conducts a comprehensive energy audit for the Federal facility and identifies improvements to save energy. In consultation with the Federal agency, the ESCO designs and constructs a project that meets the agency's needs and arranges the necessary financing. The ESCO guarantees that the improvements will generate energy cost savings sufficient to pay for the project over the term of the contract. After the contract ends, all additional cost savings from that time on accrue to the agency. Contract terms up to 25 years are allowed.

The average contract price for a Super ESPC contract undertaken by a Federal agency between 1998 and 2008 was $\$ 15.3$ million. ${ }^{20}$ Typically ESPC contracts need to be at least $\$ 1$ million to $\$ 2$ million in size to generate interest from the private sector. 2005-2009 historical data from the Super ESPC Awarded Delivery Order Summary ${ }^{21}$ shows that the average project investment per annual MMBtu savings was $\$ 131.34$. This calculation does not reflect the actual contract price, which includes the cost of financing. The average contract price over the last five years was \$337.28/MMBtu.

Given such a large difference between the project investment price and the contract price, it is worth comparing the implementation option of an ESPC contract with an appropriations-funded energy-efficiency investment. It should be noted, however, that the life-cycle costs of appropriations-funded projects versus ESPC contracts have been shown to be approximately the same, if we include all costs and the longer time cycle of appropriations funding. ${ }^{22}$

\subsubsection{Utility Energy Services Contract (UESC)}

Another way for Federal agencies to implement efficiency and renewable energy projects is through utilities. Federal agencies often enter into UESCs to implement energy improvements at their facilities. With a UESC, the utility typically arranges financing to cover the capital costs of the project. Then the agencies repay the utility over the contract term, drawing on the cost

\footnotetext{
${ }^{20}$ Federal Energy Management Program. Super ESPC Awarded Delivery Orders Summary. DOE Awarded Task Order Report. Awarded Energy Service Performance Contacts. www.femp.energy.gov/pdfs/do awardedcontracts.pdf. Accessed August 24, 2009.

${ }^{21}$ Federal Energy Management Program. Super ESPC Awarded Delivery Orders Summary. DOE Awarded Task Order Report. Awarded Energy Service Performance Contacts. www.femp.energy.gov/pdfs/do awardedcontracts.pdf. Accessed August 24, 2009.

${ }^{22}$ Hughes, P.J.; Shonder, J.A.; Sharp, T.; Madgett, M. Evaluation of Federal Energy Savings Performance Contracting-Methodology for Comparing Processes and Costs of ESPC and Appropriations Funded Energy Projects. ORNL/TM-2002/150. Oak Ridge, Tennessee: Oak Ridge National Laboratory. 2003.
} 
savings that the energy efficiency measures generate. Using this arrangement, agencies can implement energy improvements with no initial capital investment; the net cost to the Federal agency is minimal, and the agency saves time and resources by using the one-stop shopping provided by the utility.

\subsubsection{Power Purchase Agreement (PPA)}

PPAs allow Federal agencies to finance on-site renewable energy projects while incurring no upfront capital costs.

With a PPA, a developer installs a renewable energy system on agency property under an agreement that the agency will purchase the power that the system generates. The agency pays for the system through these power payments over the life of the contract. After installation, the developer owns, operates, and maintains the system for the life of the contract. Fort Carson used a PPA to finance Fort Carson's 2 MW solar array, and it would be a good option for future large projects.

\subsubsection{Appropriations, ECIP, ARRA, Etc.}

Energy projects can also be founded directly through agency or government budget mechanisms. For example, the efficiency projects that Fort Carson is currently undertaking will receive their funding from either the Energy Conservation Investment Program (ECIP) through the military, or from the American Recovery and Reinvestment Act (ARRA) through the Federal Government. Funding through these mechanisms has the advantage of reducing project financing costs. However, government funded projects are not eligible for the benefits of renewable energy generation tax credits.

\subsection{Other Implementation Considerations 10.2.1 Interconnection Requirements}

The ideal way for Fort Carson to connect its distributed energy generation systems to the electric grid is through net metering. Net metering reduces Fort Carson's electric bill by subtracting the renewable energy generated from the utility bill. If a renewable energy system generates more electricity than the current load, the additional energy can be "stored" on the electric grid to offset consumption later. Under Colorado net metering law, municipal utilities like Colorado Springs Utility must offer net metering up to $25 \mathrm{~kW}$ for commercial and industrial customers. The limit is applied per meter, and Fort Carson has only one main meter. Colorado Springs Utilities has indicated its possible willingness to negotiate a more favorable net metering agreement, such as applying the limit on a per building basis for renewable located on buildings (like rooftop PVs). Renewable systems sized to provide net zero energy, however, will be well above the net metering limit.

Fort Carson's larger renewable systems (up to $10 \mathrm{MW}$ ) will likely be interconnected under Colorado's interconnection rules, which allow systems up to $10 \mathrm{MW}$ to interconnect to the utility grid. Interconnection at this level may require studies involving project scope, feasibility, impact and facilities. Fort Carson may incur a portion of the total costs associated with these studies, and will be required to pay for liability insurance. 


\subsubsection{Incentives}

Renewable energy projects at Fort Carson are eligible for CSU solar rebates. Energy projects at Fort Carson owned by a third party with tax liability could also be eligible for Federal tax credits and accelerated depreciation. In addition, Fort Carson may also choose to sell the renewable energy credits (RECs) that would accrue to such projects. Table 34 presents an overview of these renewable energy incentives.

Table 34. Renewable Energy Incentives

\begin{tabular}{|c|c|c|}
\hline Incentive & Amount & Eligible Technologies \\
\hline \multirow[t]{2}{*}{$\begin{array}{l}\text { Federal tax } \\
\text { credit }\end{array}$} & $30 \%$ rebate on capital cost & $\begin{array}{l}\text { PV, CSP, wind, biomass, fuel } \\
\text { cells, solar vent preheat, solar } \\
\text { water heat }\end{array}$ \\
\hline & $10 \%$ rebate on capital cost & GSHP, microturbines \\
\hline $\begin{array}{l}\text { Modified } \\
\text { Accelerated } \\
\text { Depreciation }\end{array}$ & $\begin{array}{l}\text { Year 1-0.2; Year 2-0.32; Year 3- } \\
0.192 ; \text { Year 4- 0.115; Year 5- } \\
0.115 \text {; Year 6-0.058 }\end{array}$ & $\begin{array}{l}\text { PV, CSP, wind, biomass, fuel } \\
\text { cells, solar vent preheat, solar } \\
\text { water heat, GSHP, microturbines, } \\
\text { landfill gas, WTE, anaerobic } \\
\text { digestion }\end{array}$ \\
\hline $\begin{array}{l}\text { CSU solar } \\
\text { rebate }\end{array}$ & $\begin{array}{l}\$ 3 / \text { watt rebate up to a maximum } \\
\text { of } \$ 75,000(25 \mathrm{~kW})\end{array}$ & PV \\
\hline \multirow[t]{2}{*}{ REC sale } & Estimated $\$ 0.05 / \mathrm{kWh}$ for 20 years & $\mathrm{PV}, \mathrm{CSP}$ \\
\hline & $\begin{array}{l}\text { Estimated } \$ 0.001 / \mathrm{kWh} \text { for } 20 \\
\text { years }\end{array}$ & Wind, biomass electric \\
\hline
\end{tabular}

\section{National Environmental Policy Act (NEPA)}

When planning for and installing energy projects, Fort Carson must be aware of National Environmental Policy Act (NEPA) stipulations. NEPA requires Federal agencies to consider the environmental impacts of projects. NEPA requirements vary based for each specific project. The Act specifies three levels of possible required analysis: 1) categorical exclusion, 2) environmental assessment, and 3) an environmental impact statement.23 Building energyefficiency upgrades, rooftop energy systems such as PV, daylighting, and solar hot water-because they are modifications to existing facilities-could qualify for categorical exclusion. Projects such as ground-mount PV or CSP, however, could require more detailed NEPA assessments since they involve disturbing land. Environmental assessment would be required to determine if these projects would produce a significant environmental impact. If evidence of a significant environmental impact was found, NEPA would then require a more detailed environmental impact study.

\subsection{Financial Analysis}

This section presents a basic financial analysis of the recommended 2015 solution to approaching net zero energy installation status. This analysis simply provides a sample case and does not necessarily represent the actual financial costs of these recommendations. The actual

\footnotetext{
${ }^{23}$ National Environmental Policy Act. US EPA, www.epa.gov/Compliance/basics/nepa.html. Accessed April 2010.
} 
financial costs will be affected by incentive availability, installation year, and energy prices at the time of installation, and interconnection options. Assumptions used in this analysis include:

- Electricity and natural gas use changes from 2010-2015 according to projections outlined in Section 3.3.3 (based on building area growth and estimated building EUI). From 2015 to 2030, electricity and natural gas use is constant, equal to 2015 use.

- The annual inflation rate is $1.2 \%$, from NIST's 2009 Energy Price Indices Analysis report.

- The discount factor is 3\%, from NIST's 2009 Energy Price Indices Analysis report.

- The electricity price increase from 2010 to 2015 is based on CSU predictions of 12\%/year (see Section 3.4). From 2016 to 2050, electricity prices escalate at $2.2 \% /$ year ( $1 \%$ above inflation).

- Natural gas prices escalate at $2.2 \% /$ year ( $1 \%$ above inflation).

- Annual O\&M costs escalate at $1.2 \% /$ year (equal to inflation).

- O\&M costs for renewable projects are included. No savings in current O\&M costs due to displaced fossil fuel equipment is accounted for.

- All RECs are sold, at estimated values of $\$ 0.05 / \mathrm{kWh}$ for PV and CSP, and $\$ 0.001 / \mathrm{kWh}$ for wind for 40 years.

- Energy efficiency implementation cost is estimated at \$131.34/MMBtu saved based on the Super ESPC Awarded Delivery Order Summary ${ }^{24}$ that details the cost of energy savings for Federal ESPC contracts. The data utilized was the average project investment per annual MMBtu savings from the years 2005 to 2009. This calculation does not reflect the actual contract price, which includes the cost of financing.

- All investments are funded through government appropriations and owned by the government. Therefore, Federal tax credits are not included. If funded through private parties (ESPCs or PPAs, for example), a project could claim Federal tax credits valued at $\$ 177 \mathrm{M}(25.5 \%$ of initial cost). However, financing and markup rates associated with private ownership might negate savings from tax credits. We recommend additional analysis to evaluate financing alternatives.

- Project lifetime is 40 years.

- All energy is "net metered," meaning the energy is sold to and purchased from the utility at the same rate.

- Utility standby and departing load charges are not included.

- The cost implications of fleet fuel switching were not analyzed.

\footnotetext{
${ }^{24}$ Federal Energy Management Program. Super ESPC Awarded Delivery Orders Summary. DOE Awarded Task Order Report. Awarded Energy Service Performance Contacts.

www.femp.energy.gov/pdfs/do_awardedcontracts.pdf. Accessed August 24, 2009.
} 
- To simplify the analysis, all capital costs are modeled to occur in the first year and full energy savings are realized immediately. In reality, implementation would likely occur over several years.

Table 35 shows the components of the initial capital investment, annual O\&M cost, rebate, and REC payment. Note that the rebate is not included in the financial analysis.

Table 35. Initial Cost, O\&M, Rebate, and REC Sale Components

\begin{tabular}{|c|c|c|c|c|c|}
\hline & Size & Initial Cost (\$) & $\begin{array}{l}\text { O\&M } \\
(\$ / y r) \\
\end{array}$ & Rebate (\$) & $\begin{array}{r}\text { REC Sale } \\
(\$ / y r) \\
\end{array}$ \\
\hline Efficiency & $26.70 \%$ & $61,684,882$ & 0 & 0 & 0 \\
\hline Wind & $10.5 \mathrm{MW}$ & $19,509,000$ & 216,000 & $5,852,700$ & 17,967 \\
\hline PV-ground mount & $20.2 \mathrm{MW}$ & $101,000,000$ & 176,824 & $30,300,000$ & $1,473,590$ \\
\hline PV-rooftop & $24 \mathrm{MW}$ & $144,000,000$ & 238,368 & $43,200,000$ & $1,822,800$ \\
\hline PV-carport & $28.4 \mathrm{MW}$ & $213,000,000$ & 282,069 & $63,900,000$ & $1,757,960$ \\
\hline CSP & $20 \mathrm{MW}$ & $184,000,000$ & $1,750,000$ & $55,200,000$ & $2,500,000$ \\
\hline Biomass Heat & $30 \mathrm{MMBtu}$ & $10,000,000$ & 75,000 & $3,000,000$ & 0 \\
\hline Solar Vent Preheat & $119,748 \mathrm{ft}^{2}$ & $3,048,137$ & 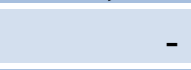 & 914,441 & 0 \\
\hline Solar Hot Water & $59,080 \mathrm{ft}^{2}$ & $4,116,429$ & 20,582 & $1,234,929$ & 0 \\
\hline GSHP & 24,684 tons & $61,710,000$ & 0 & $6,171,000$ & 0 \\
\hline Total & & $842,068,447$ & $2,960,593$ & $221,773,070$ & $7,596,869$ \\
\hline
\end{tabular}

Table 36 shows the financial analysis. The project requires a capital investment of $\$ 842$ million. It takes 35 years to recoup the initial investment. The net present value after 40 years, without Federal tax rebates, is $\$ 96$ million. The results from this analysis illustrate that if fossil energy prices rise as predicted, the near net zero energy project recommendations would provide reduced energy costs to the base over a 40 year lifetime. This analysis, however, is highly dependent on future fossil energy prices. If fossil energy prices increase at a lower rate than predicted, net present value could become negative. 
Table 36. Financial Analysis of 2015 Near Net Zero Recommendations

\begin{tabular}{|c|c|c|c|c|c|c|c|c|c|c|}
\hline & 2010 & 2011 & 2012 & 2013 & 2014 & 2015 & 2016 & 2017 & 2018 & 2019 \\
\hline \multicolumn{11}{|c|}{ Expenditures } \\
\hline Capital Cost & $842,068,447$ & & & & & & & & & \\
\hline Annual O\&M & $2,960,593$ & $2,996,120$ & $3,032,074$ & $3,068,459$ & $3,105,280$ & $3,142,544$ & $3,180,254$ & $3,218,417$ & $3,257,038$ & $3,296,123$ \\
\hline Natural Gas & $1,028,376$ & $1,084,008$ & $1,115,371$ & $1,171,526$ & $1,206,748$ & $1,218,065$ & $1,244,863$ & $1,272,250$ & $1,300,239$ & $1,328,844$ \\
\hline Total & $846,057,417$ & $4,080,129$ & $4,147,445$ & $4,239,985$ & $4,312,028$ & $4,360,609$ & $4,425,117$ & $4,490,667$ & $4,557,277$ & $4,624,967$ \\
\hline \multicolumn{11}{|c|}{ Revenues } \\
\hline $\begin{array}{l}\text { Utility Electric } \\
\text { Savings }\end{array}$ & $9,800,999$ & $11,367,903$ & $13,160,218$ & $15,563,064$ & $18,061,230$ & $20,552,521$ & $21,004,676$ & $21,466,779$ & $21,939,048$ & $22,421,708$ \\
\hline $\begin{array}{l}\text { Utility Thermal } \\
\text { Savings }\end{array}$ & $7,541,425$ & $7,949,395$ & $8,179,387$ & $8,591,194$ & $8,849,483$ & $8,932,479$ & $9,128,993$ & $9,329,831$ & $9,535,087$ & $9,744,859$ \\
\hline REC Sale & $7,572,317$ & $7,572,317$ & $7,572,317$ & $7,572,317$ & $7,572,317$ & $7,572,317$ & $7,572,317$ & $7,572,317$ & $7,572,317$ & $7,572,317$ \\
\hline Total & $24,914,741$ & $26,889,615$ & $28,911,922$ & $31,726,575$ & $34,483,030$ & $37,057,317$ & $37,705,987$ & $38,368,927$ & $39,046,453$ & $39,738,884$ \\
\hline \multicolumn{11}{|c|}{ Net Savings } \\
\hline Net Savings & $(821,142,676)$ & $22,809,486$ & $24,764,477$ & $27,486,590$ & $30,171,003$ & $32,696,708$ & $33,280,870$ & $33,878,261$ & $34,489,176$ & $35,113,917$ \\
\hline
\end{tabular}




\begin{tabular}{|c|c|c|c|c|c|c|c|c|c|c|}
\hline & 2020 & 2021 & 2022 & 2023 & 2024 & 2025 & 2026 & 2027 & 2028 & 2029 \\
\hline \multicolumn{11}{|c|}{ Expenditures } \\
\hline Annual O\&M & $3,335,676$ & $3,375,704$ & $3,416,213$ & $3,457,207$ & $3,498,694$ & $3,540,678$ & $3,583,166$ & $3,626,164$ & $3,669,678$ & $3,713,714$ \\
\hline Natural Gas & $1,358,079$ & $1,387,957$ & $1,418,492$ & $1,449,699$ & $1,481,592$ & $1,514,187$ & $1,547,499$ & $1,581,544$ & $1,616,338$ & $1,651,898$ \\
\hline Total & $4,693,755$ & $4,763,661$ & $4,834,704$ & $4,906,906$ & $4,980,286$ & $5,054,865$ & $5,130,665$ & $5,207,708$ & $5,286,016$ & $5,365,612$ \\
\hline \multicolumn{11}{|c|}{ Revenues } \\
\hline $\begin{array}{l}\text { Utility Electric } \\
\text { Savings }\end{array}$ & $22,914,985$ & $23,419,115$ & $23,934,335$ & $24,460,891$ & $24,999,030$ & $25,549,009$ & $26,111,087$ & $26,685,531$ & $27,272,613$ & $27,872,610$ \\
\hline $\begin{array}{l}\text { Utility Thermal } \\
\text { Savings }\end{array}$ & $9,959,246$ & $10,178,350$ & $10,402,273$ & $10,631,123$ & $10,865,008$ & $11,104,038$ & $11,348,327$ & $11,597,990$ & $11,853,146$ & $12,113,915$ \\
\hline REC Sale & $7,572,317$ & $7,572,317$ & $7,572,317$ & $7,572,317$ & $7,572,317$ & $7,572,317$ & $7,572,317$ & $7,572,317$ & $7,572,317$ & $7,572,317$ \\
\hline Total & $40,446,548$ & $41,169,781$ & $41,908,926$ & $42,664,331$ & $43,436,355$ & $44,225,364$ & $45,031,731$ & $45,855,838$ & $46,698,076$ & $47,558,843$ \\
\hline \multicolumn{11}{|c|}{ Net Savings } \\
\hline Net Savings & $35,752,793$ & $36,406,121$ & $37,074,221$ & $37,757,425$ & $38,456,070$ & $39,170,499$ & $39,901,066$ & $40,648,130$ & $41,412,060$ & $42,193,231$ \\
\hline & 2030 & 2031 & 2032 & 2033 & 2034 & 2035 & 2036 & 2037 & 2038 & 2039 \\
\hline \multicolumn{11}{|c|}{ Expenditures } \\
\hline Annual O\&M & $3,758,279$ & $3,803,378$ & $3,849,019$ & $3,895,207$ & $3,941,949$ & $3,989,253$ & $4,037,124$ & $4,085,569$ & $4,134,596$ & $4,184,211$ \\
\hline Natural Gas & $1,688,239$ & $1,725,381$ & $1,763,339$ & $1,802,132$ & $1,841,779$ & $1,882,298$ & $1,923,709$ & $1,966,031$ & $2,009,283$ & $2,053,488$ \\
\hline Total & $5,446,518$ & $5,528,759$ & $5,612,358$ & $5,697,339$ & $5,783,729$ & $5,871,551$ & $5,960,833$ & $6,051,600$ & $6,143,879$ & $6,237,699$ \\
\hline \multicolumn{11}{|c|}{ Revenues } \\
\hline $\begin{array}{l}\text { Utility Electric } \\
\text { Savings } \\
\end{array}$ & $28,485,808$ & $29,112,495$ & $29,752,970$ & $30,407,536$ & $31,076,501$ & $31,760,184$ & $32,458,909$ & $33,173,004$ & $33,902,811$ & $34,648,672$ \\
\hline $\begin{array}{l}\text { Utility Thermal } \\
\text { Savings }\end{array}$ & $12,380,421$ & $12,652,791$ & $12,931,152$ & $13,215,637$ & $13,506,382$ & $13,803,522$ & $14,107,199$ & $14,417,558$ & $14,734,744$ & $15,058,908$ \\
\hline REC Sale & $7,572,317$ & $7,572,317$ & $7,572,317$ & $7,572,317$ & $7,572,317$ & $7,572,317$ & $7,572,317$ & $7,572,317$ & $7,572,317$ & $7,572,317$ \\
\hline Total & $48,438,546$ & $49,337,603$ & $50,256,439$ & $51,195,490$ & $52,155,200$ & $53,136,023$ & $54,138,425$ & $55,162,879$ & $56,209,872$ & $57,279,898$ \\
\hline \multicolumn{11}{|c|}{ Net Savings } \\
\hline Net Savings & $42,992,028$ & $43,808,845$ & $44,644,082$ & $45,498,151$ & $46,371,471$ & $47,264,472$ & $48,177,592$ & $49,111,279$ & $50,065,992$ & $51,042,199$ \\
\hline
\end{tabular}




\begin{tabular}{|c|c|c|c|c|c|c|c|c|c|c|}
\hline & 2040 & 2041 & 2042 & 2043 & 2044 & 2045 & 2046 & 2047 & 2048 & 2049 \\
\hline \multicolumn{11}{|c|}{ Expenditures } \\
\hline Annual O\&M & $4,234,422$ & $4,285,235$ & $4,336,658$ & $4,388,698$ & $4,441,362$ & $4,494,658$ & $4,548,594$ & $4,603,177$ & $4,658,415$ & $4,714,316$ \\
\hline Natural Gas & $2,098,664$ & $2,144,835$ & $2,192,021$ & $2,240,246$ & $2,289,531$ & $2,339,901$ & $2,391,379$ & $2,443,989$ & $2,497,757$ & $2,552,707$ \\
\hline Total & $6,333,086$ & $6,430,070$ & $6,528,679$ & $6,628,943$ & $6,730,893$ & $6,834,559$ & $6,939,973$ & $7,047,166$ & $7,156,172$ & $7,267,024$ \\
\hline \multicolumn{11}{|c|}{ Revenues } \\
\hline $\begin{array}{l}\text { Utility Electric } \\
\text { Savings }\end{array}$ & $35,410,943$ & $36,189,984$ & $36,986,164$ & $37,799,859$ & $38,631,456$ & $39,481,348$ & $40,349,938$ & $41,237,636$ & $42,144,864$ & $43,072,051$ \\
\hline $\begin{array}{l}\text { Utility Thermal } \\
\text { Savings }\end{array}$ & $15,390,204$ & $15,728,789$ & $16,074,822$ & $16,428,468$ & $16,789,895$ & $17,159,272$ & $17,536,776$ & $17,922,585$ & $18,316,882$ & $18,719,854$ \\
\hline REC Sale & $7,572,317$ & $7,572,317$ & $7,572,317$ & $7,572,317$ & $7,572,317$ & $7,572,317$ & $7,572,317$ & $7,572,317$ & $7,572,317$ & $7,572,317$ \\
\hline Total & $58,373,465$ & $59,491,090$ & $60,633,303$ & $61,800,645$ & $62,993,668$ & $64,212,937$ & $65,459,031$ & $66,732,539$ & $68,034,064$ & $69,364,222$ \\
\hline \multicolumn{11}{|c|}{ Net Savings } \\
\hline Net Savings & $52,040,379$ & $53,061,020$ & $54,104,624$ & $55,171,701$ & $56,262,775$ & $57,378,378$ & $58,519,058$ & $59,685,373$ & $60,877,892$ & $62,097,198$ \\
\hline
\end{tabular}




\section{Conclusion}

NREL's net zero analysis evaluated opportunities for energy efficiency, renewable energy, and transportation fuel reduction at Fort Carson. The analysis shows that Fort Carson has the potential to make significant progress toward becoming a net zero installation. If the base implements the recommended energy projects and savings measures, it would achieve a $92 \%$ site energy reduction and a 95\% source energy reduction. By achieving this status, the base will set an example for other military installations, provide environmental benefits, reduce costs, increase energy security, and exceed its goals and mandates. 


\section{Appendix A. Electric Vehicle Grid Integration}

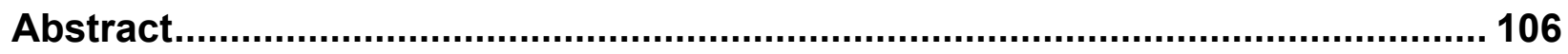

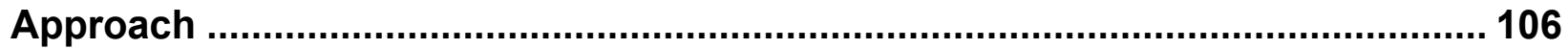

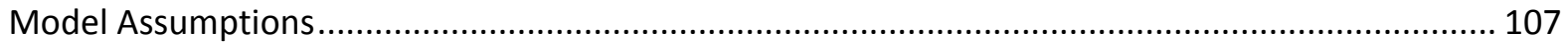

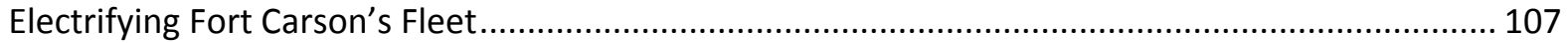

Consumer Adoption of Electric Vehicles .................................................................... 109

Fort Carson Electrical Loads ................................................................................ 113

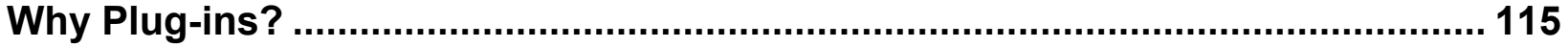

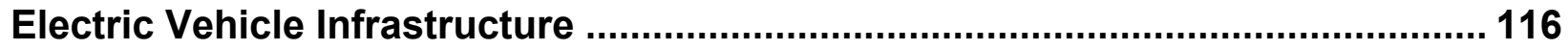

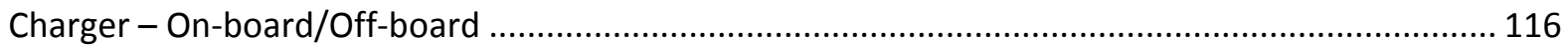

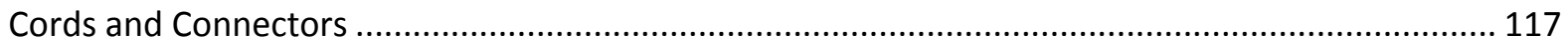

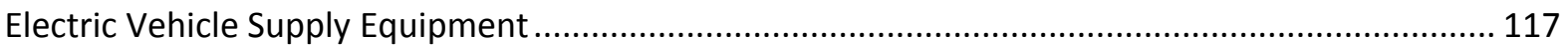

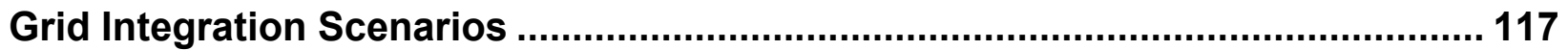

Scenario 1: Vehicle Charging (without management) .......................................................... 118

Scenario 2: Vehicle Charging (with management) ............................................................. 118

Scenario 3: Vehicle Charging and Discharging (with management) ........................................ 124

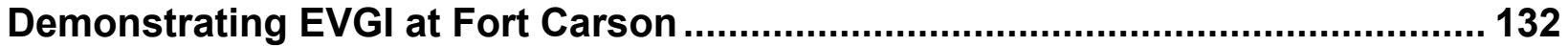

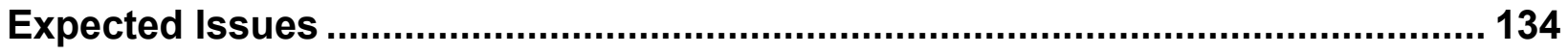

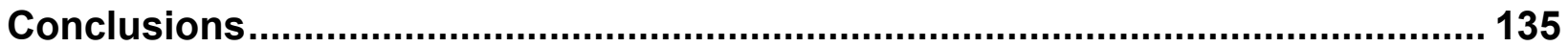




\section{Abstract}

Following the definition provided by the DoD/DOE Net Zero Analysis Task Force, a net-zero Fort Carson will require significant on-site energy generation and a high-efficiency fleet that can utilize on-site energy sources, among many other changes. As the availability and affordability of distributed renewable energy generation options will likely increase during the next decade, so will the plug-in vehicle options. NREL anticipates that Fort Carson will interact with plug-in vehicles belonging to the transportation motor pool as well as its military and civilian commuters.

Specifically, the base's alignment with the Army-funded demonstrations of all-electric trucks will ensure that a small number of electrified vehicles will soon reside on site. This report summarizes the potential costs and benefits of possible electric vehicle grid integration (EVGI) scenarios at Fort Carson. NREL has found that even at relatively small adoption rates, the control of electric vehicle charging at Fort Carson will aid in regulation of variable renewable generation loads and help stabilize the grid/microgrid.

NREL recommends continued collaboration with Fort Carson to definitively understand the impacts of electric vehicles on the grid during both normal and microgrid operations.

\section{Approach}

NREL investigated multiple applications of plug-in electric vehicles (PEVs) searching for feasible benefits in the form of petroleum reduction, renewables integration, and microgrid stability. This analysis first considers the management of all-electric fleet vehicles. Analysts simulated the deployment of representative models of electric trucks available via GSA as substitutes for using vehicles in the Fort Carson Motor Pool.

Next, NREL modeled commuter electric vehicles, based on performance and nationwide rollout plans for the Nissan Leaf and GM Volt. ${ }^{25}$ Light-duty PEVs are currently in production and scheduled to arrive at select dealerships and in national fleets in the fall of 2010. The model assumes that a small portion of the Fort Carson commuter fleet will plug in on-base.

In the coming years, vehicles will for the first time utilize the electric grid. To assess the electric grid impacts of PEVs, NREL modeled Fort Carson's electricity demand profile under both typical loads, and loads during critical operations (with a lower, more variable base load representative of emergency islanding as a microgrid). We analyzed three primary vehicle-grid interactions:

- Full-power charging without management

- Full-power charging capability, controlled by local grid authority

- Full-power charge and discharge capability, controlled by local grid authority.

Management of the PEV charging rates will allow the base to regulate and eventually optimize electrical loads for peak generator efficiency with high utilization rates for renewable energy. These simulations assume two-way communication between the grid operator and the vehicles

\footnotetext{
${ }^{25}$ Voiced by Nissan and GM executives and the DOE Plug-in Vehicle and Infrastructure Workshop, July 22, 2010.
} 
(or a third-party aggregator). Grid and vehicle fleet will exchange information regarding how many vehicles are available as well as their batteries' states of charge.

\section{Model Assumptions}

Each vehicle in the model represents one of the 18,789 commuters who live off-base. We categorize these vehicles as either conventional, plug-in hybrid electric vehicle (PHEV), allelectric vehicle (AEV), or GSA fleet electric trucks. To simplify analysis, each PHEV, AEV, and electric truck sub-fleet described below in Table A-1 is categorized with generic characteristics representative of similar PEV options expected to be available in the market by late 2010 .

Table A-1. Modeled Vehicle Characteristics

\begin{tabular}{|l|r|r|r|r|}
\hline Vehicle Type & PHEV & AEV & $\begin{array}{r}\text { Electric } \\
\text { Truck }\end{array}$ & \\
\hline Battery Capacity & 12 & 25 & 80 & $\mathrm{kWh}$ \\
\hline $\begin{array}{l}\text { Energy } \\
\text { Consumption }\end{array}$ & 300 & 250 & 800 & $\mathrm{Wh} / \mathrm{mi}$ \\
\hline $\begin{array}{l}\text { Charge-Depleting } \\
\text { Range }\end{array}$ & 40 & 100 & 100 & $\mathrm{mi}$ \\
\hline Life-Expectancy & 15 & 15 & 15 & years \\
\hline $\begin{array}{l}\text { EVSE Charge } \\
\text { Level }\end{array}$ & 2 & 2 & & \\
\hline
\end{tabular}

Each vehicle operates independently in these simulations but also influences the net effects. This electric fleet - carrying multiple megawatt-hours of storage — creates an important dynamic resource for Fort Carson.

\section{Electrifying Fort Carson's Fleet}

The NEL assessment found that nearly one quarter of the 500-vehicle GSA-leased transportation motor pool (TMP) is currently well-suited for replacement with one of the three all-electric truck options now available via the GSA. Further projections of PEV mass market penetration vary widely, but for this study we assume a steady growth in electric truck acquisition based on a Bass technology diffusion curve ${ }^{26}$ and Energy Information Administration forecasts ${ }^{27}$ as Figure A-1 shows.

\footnotetext{
${ }^{26}$ Bass, Frank M. 1963. “A Dynamic Model of Market Share and Sales Behavior,” Frank M. Bass, Proceedings, Winter Conference American Marketing Association, Chicago, IL.

${ }^{27}$ Bureau of Transportation Statistics, www.bts.gov/publications/state transportation_statistics/state transportation_statistics_2009/. Retrieved July 1, 2010 .
} 


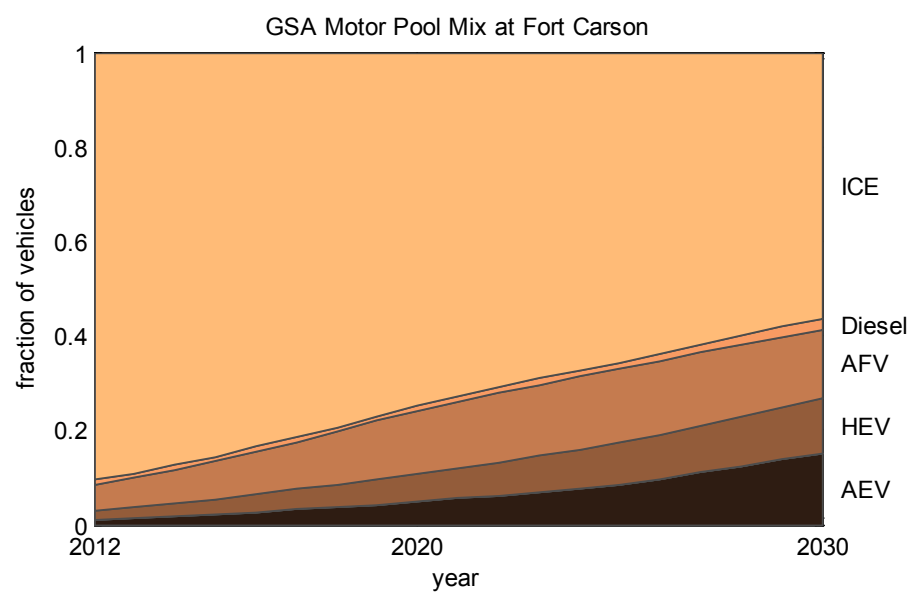

Figure A-1. Assumed GSA vehicle adoption

The Directorate of Logistics and the Directorate of Public Works at Fort Carson indicated that transport shuttles, bucket trucks, stake trucks, and refrigerated vans all represent highly valuable roles of PEVs on base. Their mission of continuous, short trips during the day on-base, returning to the same lot each night, reflects the ideal electric vehicle duty cycle. Similarly utilized delivery vans and general use medium-duty trucks also present valid opportunities for electric drive.

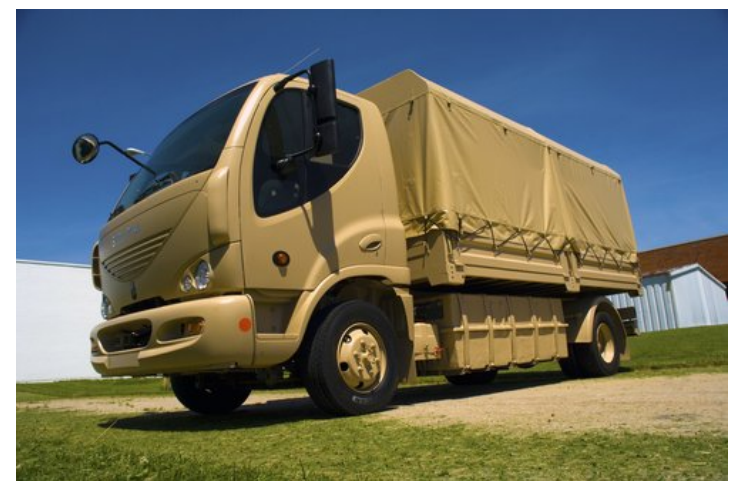

Figure A-2. The Smith Electric Newton all-electric truck, upfitted into one of many different configurable options (Credit: Smith Electric Vehicles, PIX 17631)

Table A-2. Electric Truck Options Available on the 2010 GSA Schedule

\begin{tabular}{|l|r|r|r|}
\hline GSA Vehicles & Smith Newton & Zero Truck ZT & Enova Ze \\
\hline GVWR Class & 4 to 6 & 3 to 5 & 3 to 4 \\
\hline GSA Item Number & $571 \mathrm{E} .1$ & $95 \mathrm{E}$ & $134 \mathrm{E} .1$ \\
\hline Maximum Range $(\mathrm{mi})$ & 100 & 75 & 150 \\
\hline Maximum Speed $(\mathrm{mph})$ & 50 & 60 & 65 \\
\hline GSA Base Price & $\$ 167,000$ & $\$ 142,100$ & $\$ 109,500$ \\
\hline Incremental Cost & $\$ 109,548$ & $\$ 119,573$ & $\$ 80,309$ \\
\hline
\end{tabular}


Each of these medium-duty commercial platforms has a large battery capacity $(60-120 \mathrm{kWh})$ to meet typical daily driving distance requirements and at least one will have the opportunity to fast charge at rates of nearly $20 \mathrm{~kW}$ (see Table A-2). This will provide adequate mission capability for intra-base delivery, troop transportation, ambulance support, civilian shuttles, and other executive services. At current utility charges, fuel to drive each mile will cost less than $\$ 0.03$, roughly $80 \%$ less than the gasoline that current TMP trucks and vans consume, as Figure A-3 shows. ${ }^{28}$

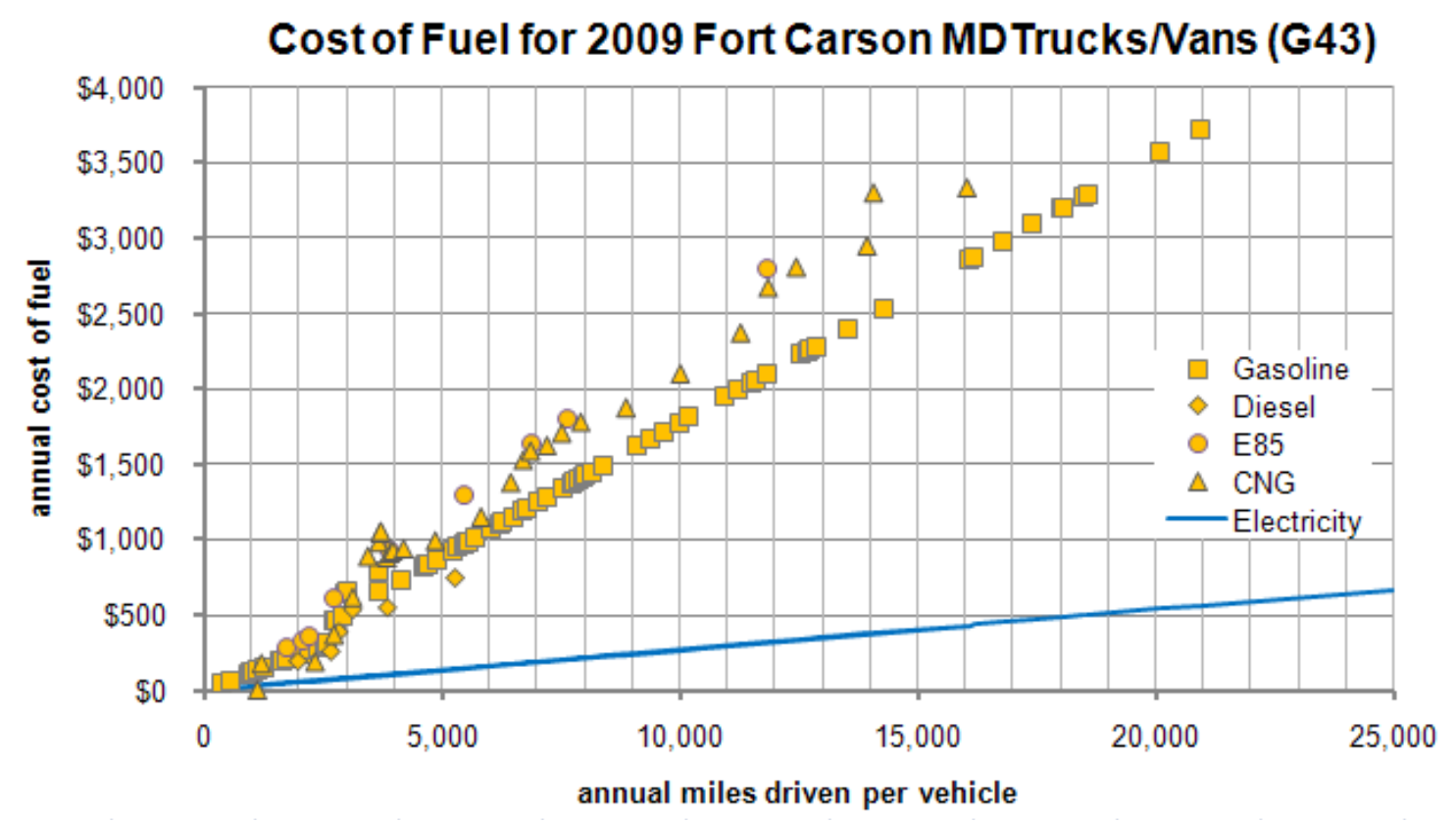

Figure A-3. Vehicle technology operational cost comparison

\section{Consumer Adoption of Electric Vehicles}

In addition to GSA-leased electric vehicles, commuter electric vehicles will be soon available and in close competition with today's conventional and hybrid options. After over two years of publicly affirmed dedication to commercially available all-electric and plug-in hybrid electric vehicles by automotive manufacturers, battery manufacturers, and the U.S. Department of Energy - the near-term certainty of public adoption is established.

\footnotetext{
${ }^{28}$ Estimate is based on Colorado Springs Utility rates, June 2010. Maintenance and acquisition costs are excluded.
} 


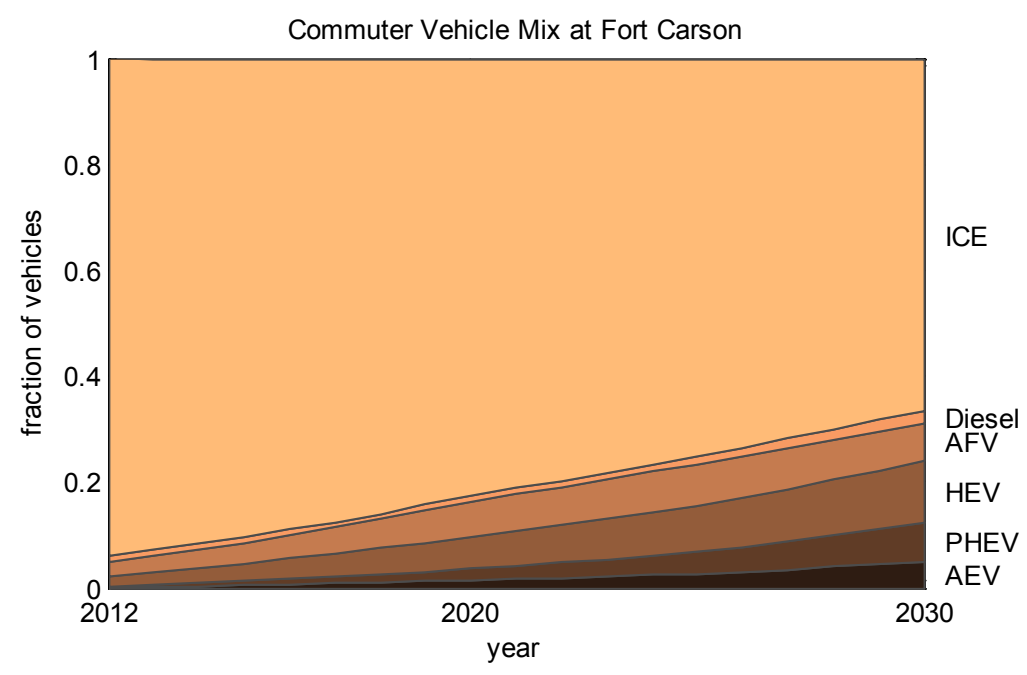

Figure A-4. Assumed vehicle adoption trends

The longer term adoption trend between today and 2030 is a matter of less certainty, but we may estimate it in a similar manner as that used for motor pool vehicle turnover, as Figure A-4 shows. Vehicle life expectancy (in Table A-1) determines the time of retirement of each asset. We expect sales of AEVs to grow at a similar rate to PHEVs, but PHEVs occupy a larger market fraction because of their added range capabilities.

More than 30,000 people work at Fort Carson each week day and nearly all commute individually ${ }^{29}$ This model considers the 18,289 that come in each day from off-base. We used a database containing the zip codes of Fort Carson's commuters to approximate travel distance (and thus the energy required to make that trip) for each (see Figure A-5). Our analysis assumed that each employee drove to Fort Carson in a single-occupancy vehicle from the center of their mailing address zip code.

29 Discussions with Fort Carson personnel. 


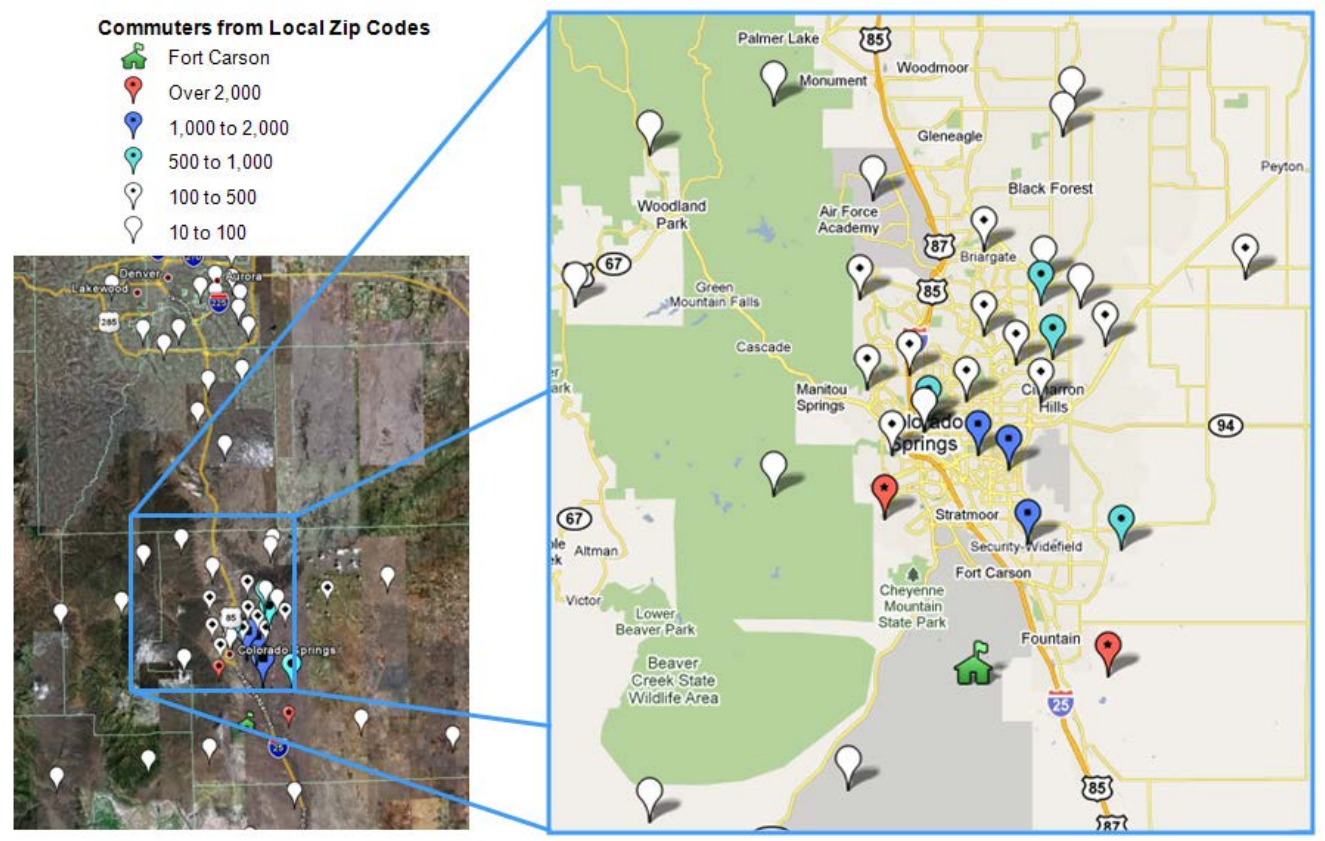

Figure A-5. Starting locations for Fort Carson commuters

The analysis assigned each commuter a likelihood of driving an all-electric vehicle (AEV) or a plug-in hybrid electric vehicle (PHEV) based on market sales of these vehicles in the Colorado Springs region as well as on their commute distance relative to the vehicle maximum range. A safety factor of 2.2 times the commute distance was applied to this range-based-selection, so that even without a charge at work, each commuter could complete a round trip with $20 \%$ capacity to spare.

The subject fleet in these analyses represents the 2030 PEV adoption rates, as Figure A-6 summarizes. Nearly $80 \%$ of the total commuter-miles traveled each day were in commutes within 40 miles. In the future, therefore, AEVs and PHEVs represent ideal choices, being capable of providing all-electric transportation for these distances. 

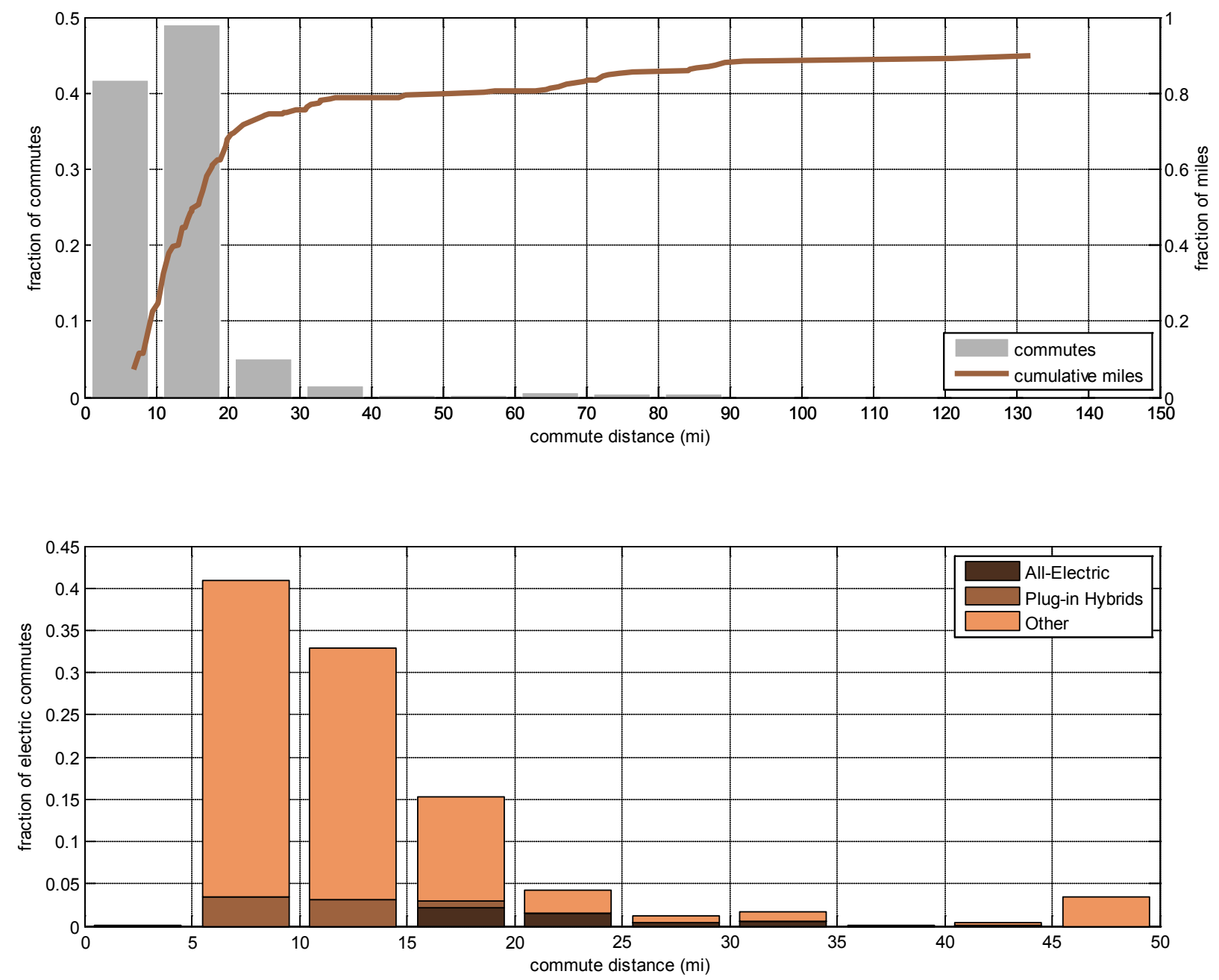

Figure A-6. Commuter distance from Fort Carson (top) and PEV mix (bottom)

NREL created energy storage resource allocation profiles by assuming the times during which vehicles were present at the base. We modeled the motor pool was modeled in similar fashion, although we assumed it to operate during the day and park at night and throughout weekends.

We modeled the gradual phase-in of commuters (and commuter energy) as the motor pool (and motor pool energy) phased out during the morning as a function of a random distribution applied to arrival and departure times. The opposite trends occurred in the evening as commuters departed and motor pool vehicles returned. During weekdays the commuters in this model arrive at 8:00 am, plus or minus a standard deviation of 30 minutes, and leave 9 hours 30 minutes later, plus or minus 30 minutes standard deviation (not present on weekends). Figure A-7 summarizes these schedules and the energy storage potential in the 2030 PEVs. 


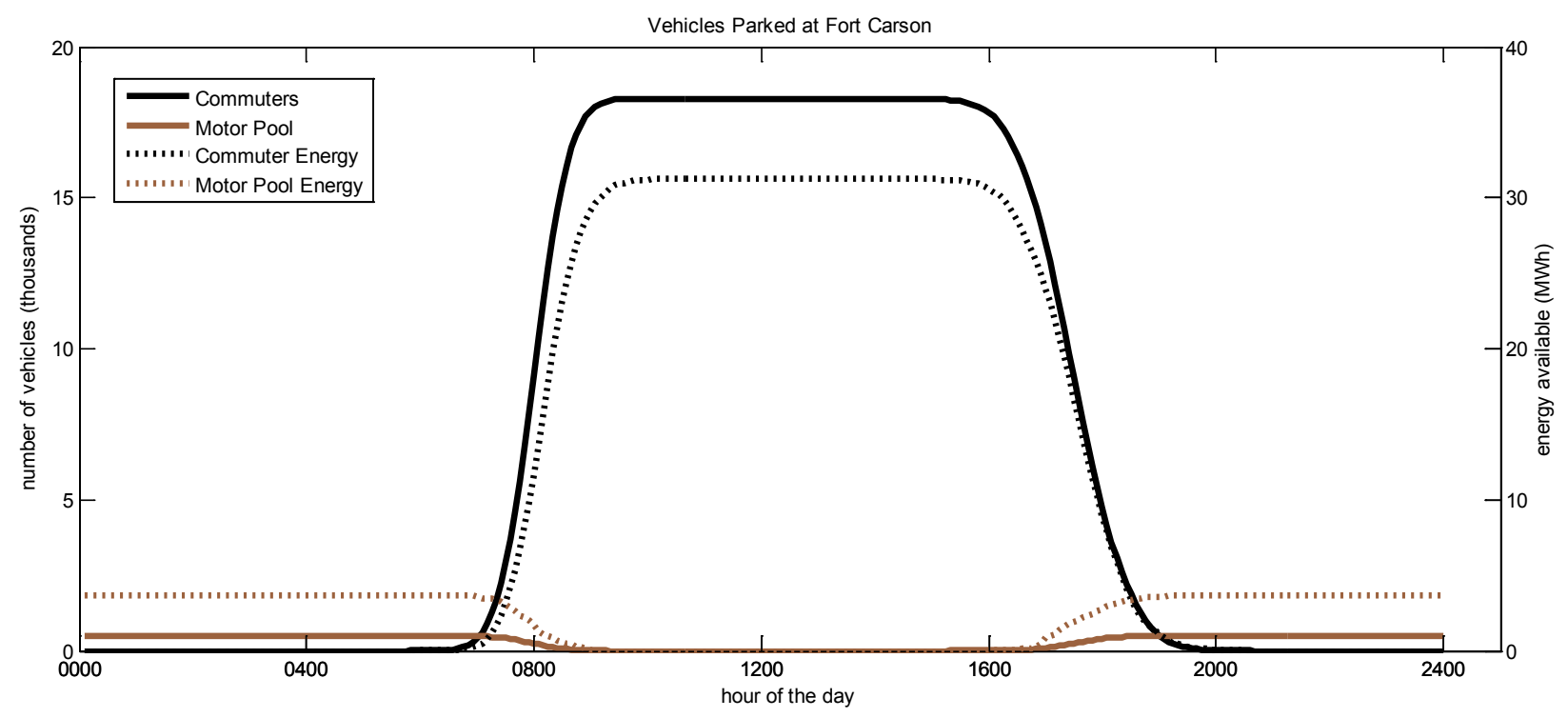

Figure A-7. Commuter and fleet vehicles avaiable at Fort Carson during weekdays

\section{Fort Carson Electrical Loads}

Sandia National Laboratory's microgrid assessment defined the critical loads used in the emergency scenario simulations. We then interpolated these hourly average demands (peaking at 4.3 MW) and scaled them to approximate the average demands during normal operations (peaking at over $25 \mathrm{MW}$ ).

Solar power production data is not yet available from Fort Carson; however, analysts took data from meters on NREL's solar array and scaled them to $2 \mathrm{MW}$, representative of the current array size on-base. We then subtracted the resulting power from the demand load, to provide the net loads that the utility must generate.

Utility generation profiles during normal operations represented Colorado Springs Utilities' fuel mix from 2009, ${ }^{30}$ scaled to the demand profile of the simulation time period (see Table A-3).

Table A-3. Colorado Spring Utilities' Fuel Mix, 2009

\begin{tabular}{|l|r|r|r|}
\hline Resource & $\begin{array}{r}\text { Capacity } \\
\text { (MW) }\end{array}$ & $\begin{array}{r}\text { Power } \\
\text { (MW) }\end{array}$ & $\begin{array}{r}\text { Energy } \\
\text { (MWh) }\end{array}$ \\
\hline Coal & 462 & $42 \%$ & $61 \%$ \\
\hline Hydro & 34 & $10 \%$ & $27 \%$ \\
\hline Natural Gas/Oil & 115 & $46 \%$ & $8 \%$ \\
\hline Wind & 0 & $0 \%$ & $0 \%$ \\
\hline DSM & 0 & $2 \%$ & $1 \%$ \\
\hline Purchases & 0 & $0 \%$ & $3 \%$ \\
\hline
\end{tabular}

\footnotetext{
${ }^{30}$ Colorado Spring Utilities' Evaluation of Potential Options to Meet the $\mathrm{CO}_{2}$ Reduction Goals of the Colorado Climate Action Plan. www.csu.org/residential/environment/renewable/standard/item5137.pdf, June 1, 2009. Accessed July 22, 2009.
} 
The final generation profile was an estimate that depicts how each rise or fall in demand can affect the fuel consumption and emissions of the electric grid. Colorado Spring Utilities consumes mostly coal to provide a stable base load. The utility also takes advantage of the natural water resources in the area to provide over one-quarter of their energy cleanly with hydro-power. Figure A-8 presents typical week.

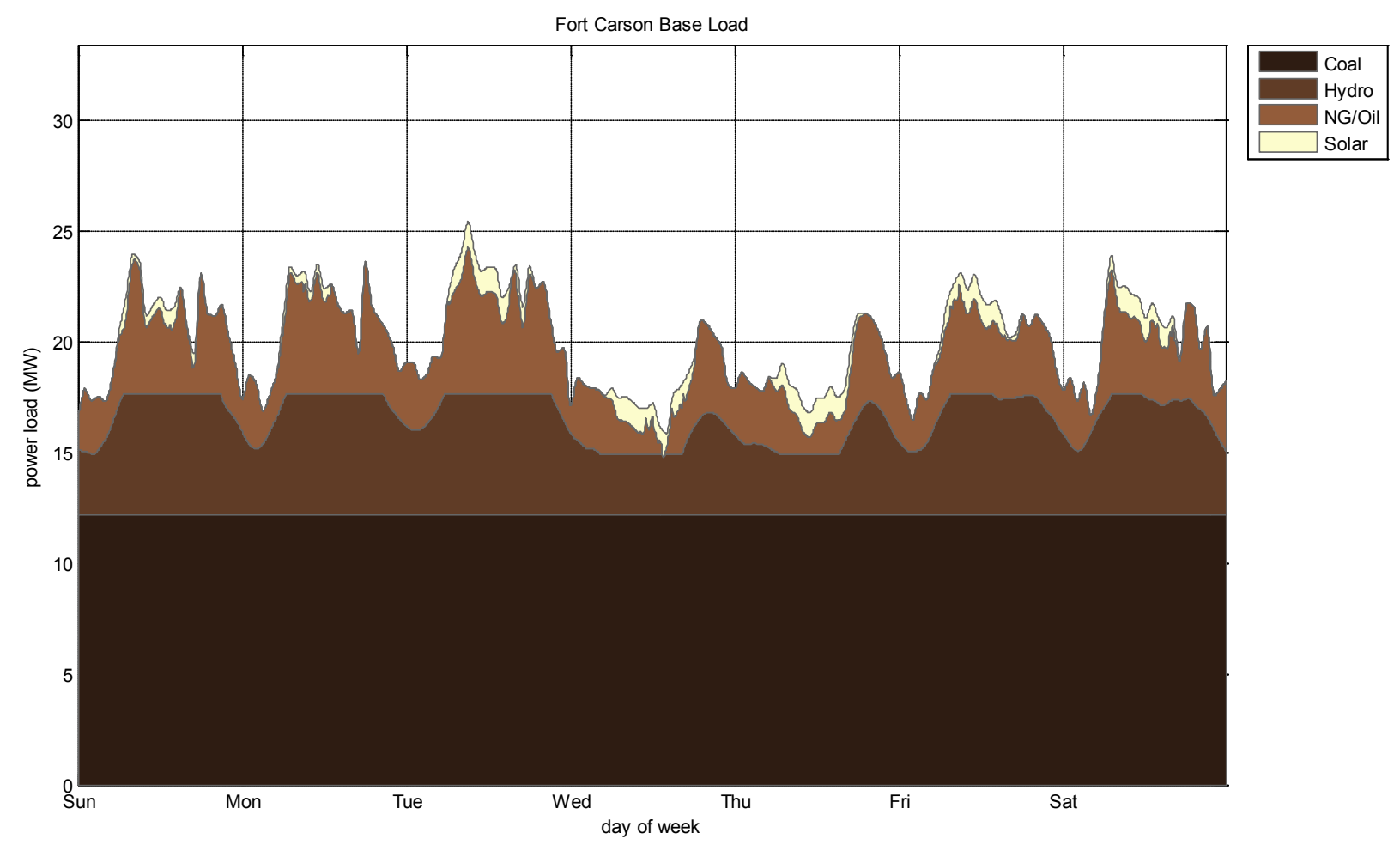

Figure A-8. Base load at Fort Carson with conventional and solar generation mix during normal operations

During emergency operations, NREL assumed that the base will run a series of diesel generators to meet the needs of mission critical loads, while still incorporating the same level of solar power. Any grid instabilities created by power fluctuations from on-site variable renewable generation will be magnified in a critical load scenario. Figure A-9 displays the emergency generation profile during the same week as in Figure A-8, presenting up to $25 \%$ load variance between peak and trough. Generators operate most efficiently in relatively narrow power bands; this diurnal ramping will increase total fuel needs as the generators move through these bands. 


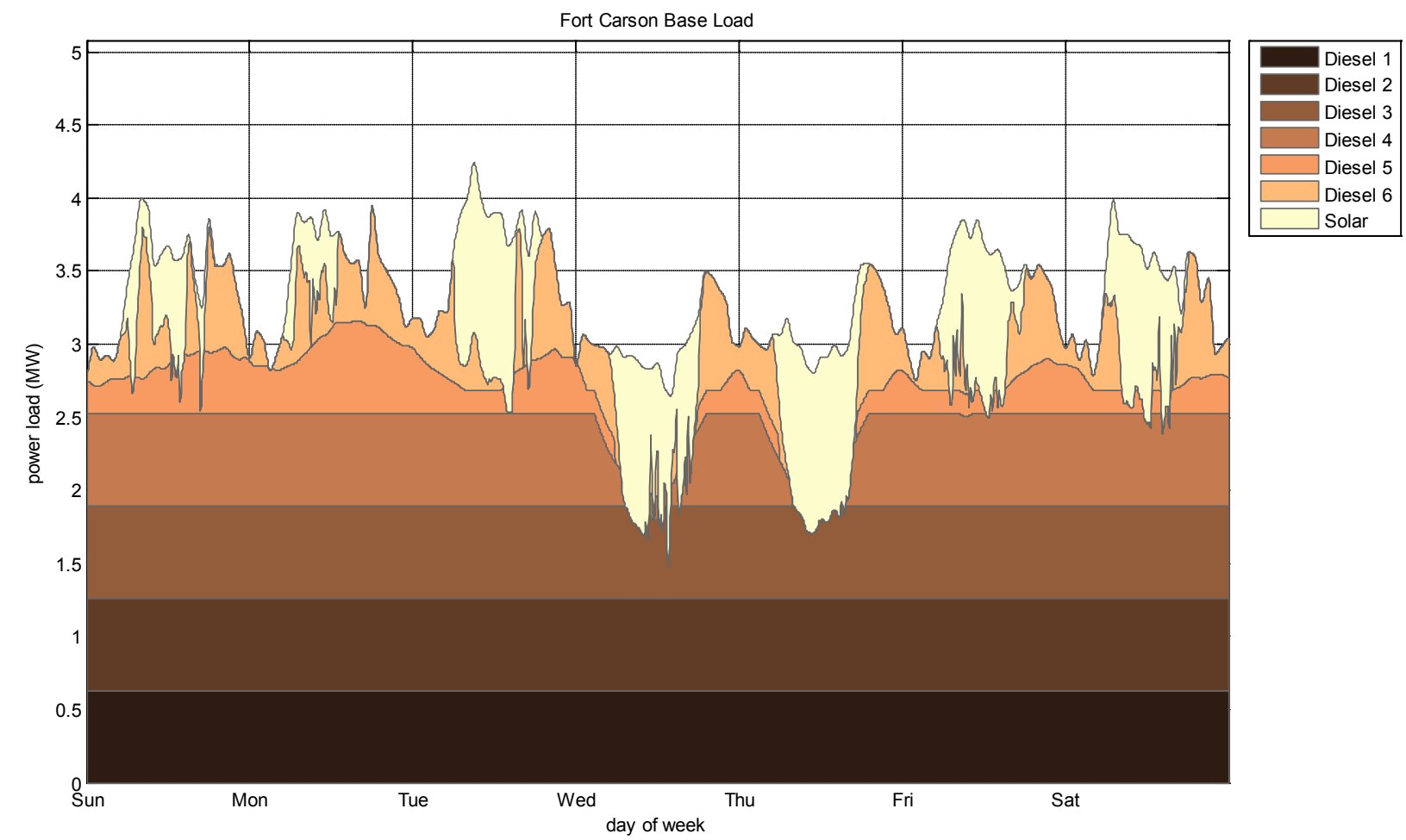

Figure A-9. Emergency demand and generation profile

It is important to note that the load profiles used for these scenarios do not reflect actual loads at Fort Carson because that data was not recorded at the time of this analysis. Proper grid utilization of PEVs depends heavily on the proper matching of vehicle usage profiles, infrastructure, and grid activity.

\section{Why Plug-ins?}

Plug-in vehicles range from plug-in hybrid electric vehicles (PHEVs) of varying battery capacities (and all-electric ranges) to all-electric vehicles (AEVs, or EVs); both offer two potential benefits to the operator:

- High rates of petroleum consumption displacement (via enhanced efficiencies) ${ }^{31}$

- Clean and affordable operations (via fuel diversity from relatively inexpensive and potentially renewable sources). ${ }^{32}$

These automotive technologies, when deployed appropriately with the proper control, can also facilitate the build-out and maintenance of a cleaner, more reliable grid. While parked — and the

\footnotetext{
${ }^{31}$ Markel, T.; Smith, K.; Pesaran, A. "Improving Petroleum Displacement Potential of PHEVs Using Enhanced Charging Scenarios" EVS24.

${ }^{32}$ Parks, K.; Denholm, P.; Markel, T. Costs and Emissions Associated with Plug-In Hybrid Electric Vehicle Charging in the Xcel Energy Colorado Service Territory. NREL/TP-640-41410. May 2007.
} 
average car is parked more than $90 \%$ of the time ${ }^{33}$ — plug-in cars will provide a flexible load or possible energy storage with adjustable charge and discharge capabilities. NREL found that if Fort Carson applies such grid stability options to its microgrid, the base may experience amplified savings and power quality benefits when compared with larger, more regional operations.

Although they bear a high initial price, the financial benefits of electrified vehicles during operation may pay for incremental costs amortized throughout the period of vehicle ownership. For the purposes of this study, $P E V S$ will represent the multiple electrified vehicle configurations, and $P E V$ operations will consist of both transportation and smart grid integration (charging, discharging, communications, etc.).

\section{Electric Vehicle Infrastructure}

An electric fleet will require the following infrastructure ${ }^{34}$ in the same way that a conventionallyfueled fleet will require maintenance equipment, storage accommodations, and fueling infrastructure. Though standardization is currently lacking, commercial options exist for each item:

\section{Charger-On-board/Off-board}

The power electronics for charging the energy storage system could be on-board or off-board the vehicle. Improving the efficiency and cost of this component may be critical to the success of electrified transportation. The weight of on-board units is also important. On-board units take AC power from the grid and rectify it to DC power in order to charge the DC battery pack. Offboard units make this same conversion and deliver DC power to the vehicle. There must be communication between the battery management system and the charger to ensure the safe delivery of energy. Power-quality standards for chargers are under development, with the goal of minimizing detriment al impacts to grid operation.

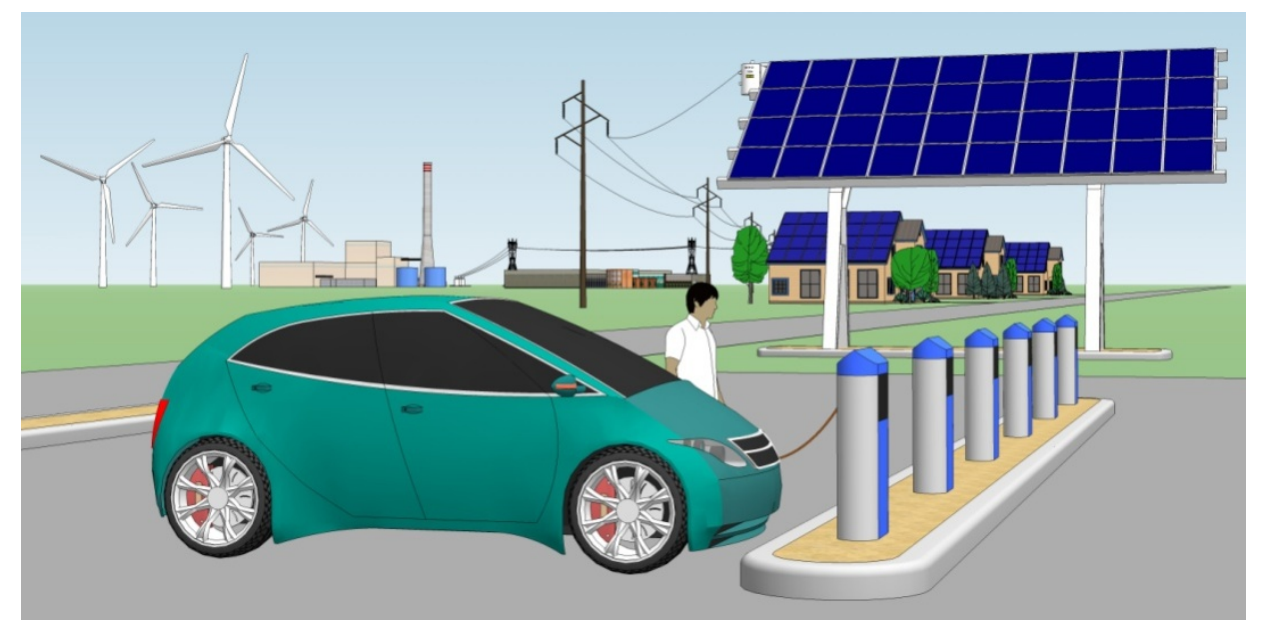

Figure A-10. Illustration of PEV infrastructure (Credit: Dean Armstrong, NREL)

\footnotetext{
${ }^{33}$ Markel, T.; Kuss, M.; Denholm, P. "Communication and Control of Electric Drive Vehicles Supporting Renewables.” IEEE Vehicle Power and Propulsion Systems Conference, September 2009.

${ }^{34}$ The following descriptions are taken from Markel, T. "Plug-in Electric Vehicle Infrastructure: A Foundation for Electrified Transportation.” MIT Energy Initiative, April 8, 2010.
} 
Vehicle charging infrastructure also offers the opportunity to reverse power flow from the vehicle battery to the grid. Users must balance, however, the value of this scenario with its inefficiency and battery-life impacts.

Chargers and associated cords are categorized by voltage and power levels: Level I is $120 \mathrm{~V} \mathrm{AC}$ up to $20 \mathrm{~A}(2.4 \mathrm{~kW})$, Level II is $240 \mathrm{~V}$ AC up to $80 \mathrm{~A}(19.2 \mathrm{~kW})$, and Level III (which is yet to be defined fully) will likely be $240 \mathrm{~V}$ AC and greater at power levels of $20-250 \mathrm{~kW} \cdot{ }^{35} \mathrm{It}$ is expected that similar definitions will be created to categorize charging with DC power delivery.

During these simulations, the commuter vehicles charge (and discharge) via Level II architecture (limited to $7.7 \mathrm{~kW}: 32$ amps, 240 Volts). The electric fleet trucks use Level III (limited to 20 $\mathrm{kW}: 50$ amps, 400 Volts DC).

\section{Cords and Connectors}

In the previous generation of EVs, cords and connectors became a point of debate and made introduction challenging. Today, SAE has led efforts for United States-wide standardization of connectors for conductive charging. The SAE J1772 standard defines a five-pin configuration that will be used for Level I and Level II charging. ${ }^{35} \mathrm{SAE}$ is investigating the use of the J1772 connector for DC power flow as well. Level III connectors are under development. Tripping hazards due to cords in garage areas and public places may be a safety and adoption hurdle.

\section{Electric Vehicle Supply Equipment}

Electric vehicle supply equipment (EVSE) improves the safety of vehicle charging in accordance with the National Electric Code (NEC). The EVSE enables power flow between the electricity distribution system and the PEV only when a cord and connector are completely connected. For Level II charging, the cord is permanently attached to the EVSE and is de-energized when not connected to the vehicle inlet. The EVSE and charger may be a single component if the charger is located off-board the vehicle. In some regions, the EVSE will be attached to or include a submeter for measuring electricity delivered to the vehicle separate from electricity delivered to the rest of the premise. This feature supports low-carbon fuel standard accounting.

The installation of an EVSE in a building may present a significant hurdle to adoption because it involves multiple parties, including utilities, building inspectors, electricians, and vendors. ${ }^{36}$ The time from purchase to functioning installation might be as much as 30 days in some regions providing a less than ideal experience for consumers. A discussion of related codes and standards efforts follows.

\section{Grid Integration Scenarios}

The Fort Carson EVGI forecast yielded a fleet of 908 AEVs, 1,362 PHEVs, and 75 electric motor pool trucks in 2030. These vehicles occupied parking spaces in this simulation during the same assumed times as the internal combustion engine (ICE) vehicles they replaced. When plugged in to EVSE at these parking spaces, vehicles charged or discharged based on a series of algorithms and limits framed in three scenarios.

\footnotetext{
35 "SAE Electric Vehicle and Plug in Hybrid Electric Vehicle Conductive Coupler." SAE J1772. January 2010.

36 "Electric Vehicle Charging Infrastructure Deployment Guidelines British Columbia.” BC Hydro. July 2009.
} 
NREL chose these scenarios to capture the most likely range of grid-integration effects: 1)those that require little or no work with the highest risks (vehicle charging without management), 2) those that require some work with the least risk (vehicle charging with management), and 3) those with the greatest benefits and the greatest costs (vehicle charging and discharging with management).

\section{Scenario 1: Vehicle Charging (without management)}

Also known as opportunity charging, ${ }^{31}$ unmanaged charging began in these simulations at the maximum rate as soon as the vehicle was parked and plugged in. At Fort Carson, opportunity charging coincided with demand peaks, creating wildly high electricity loads [and costs] as Figure A-11 shows. Each large spike in the morning adds more than $7 \mathrm{MW}$ to the base load. Vehicle charge energy totals $11 \mathrm{MWh}$ each day.

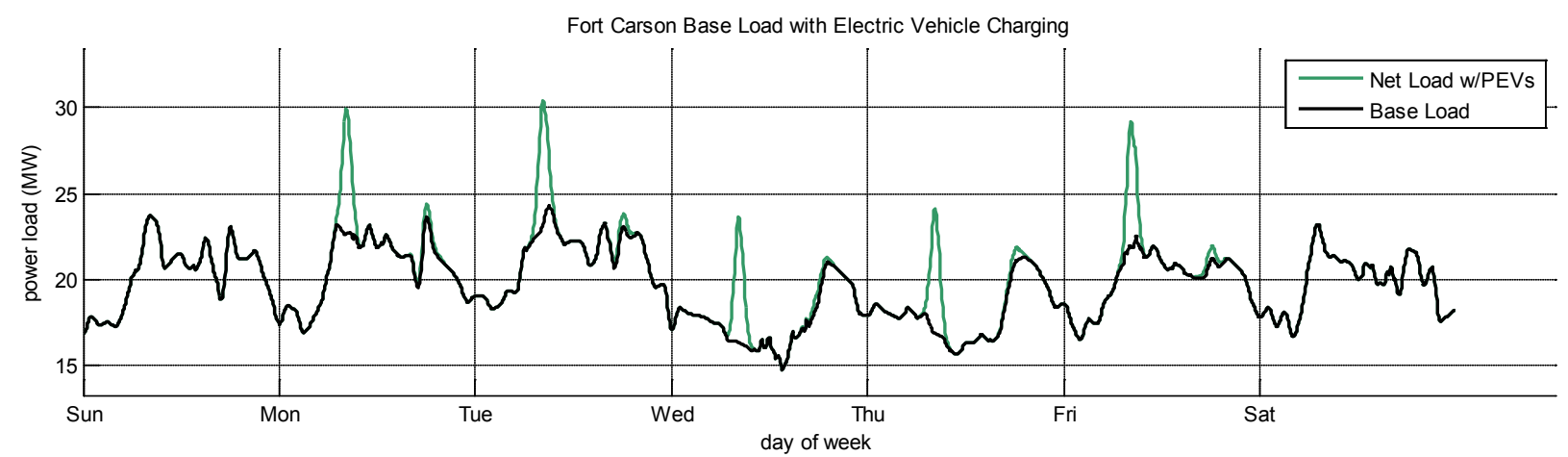

Figure A-11. Opportunity charging at Fort Carson during normal operations

Next, we analyzed a critical-load scenario within an islanded Fort Carson, when only GSA electric trucks are plugged in and 50\% of them still operate during the weekdays. Unmanaged charging results in $800 \mathrm{~kW}$ additional loads totaling 1.4 MWh each day, as Figure A-12 shows.

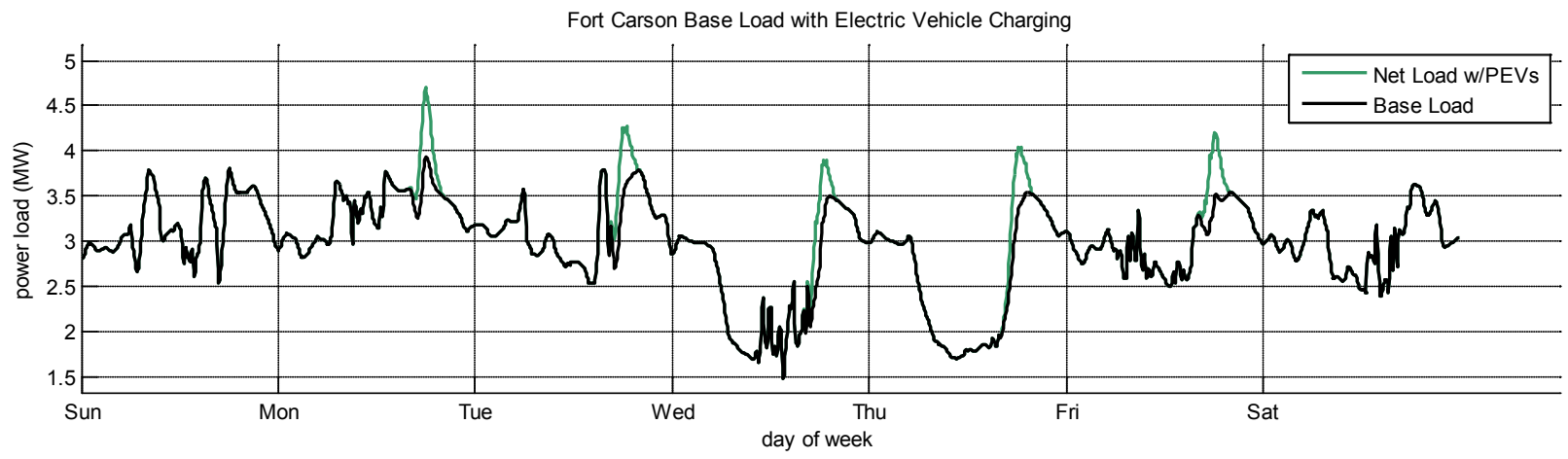

Figure A-12. Opportunity charging during emergency microgrid operations

Scenario 2: Vehicle Charging (with management)

Today, regional utilities employ demand response programs to reduce excess costs during peaking demands by curtailing certain customer equipment under specific agreements in 
exchange for payment to the customer. In a similar fashion, controlled charging of vehicles is another load that grid operators can regulate to counter any large demand or supply transients, which could damage equipment or even cause blackouts.

Under the NZEI initiative, Fort Carson may add renewable energy generation to the $2 \mathrm{MW}$ of solar photovoltaic arrays already on-base. Compared with fossil fuel generators, renewable supplies can vary widely with unexpected changes in the weather. Increasing the utilization rate of renewable generation while reliably meeting the demand requires a buffer, which is a role that parked (and plugged in) PEVs may play well.

The electric fleet could smooth many of the power drops during periods where large numbers of commuters were parked on base by regulating charging. However, as Figure A-13 shows, many quick changes of $20 \%$ or more of the peak demand still occurred within only a few hours and without compensation. These fluctuations may create significantly more costs for the utility than the savings resulting from smoothing with PEV charging.

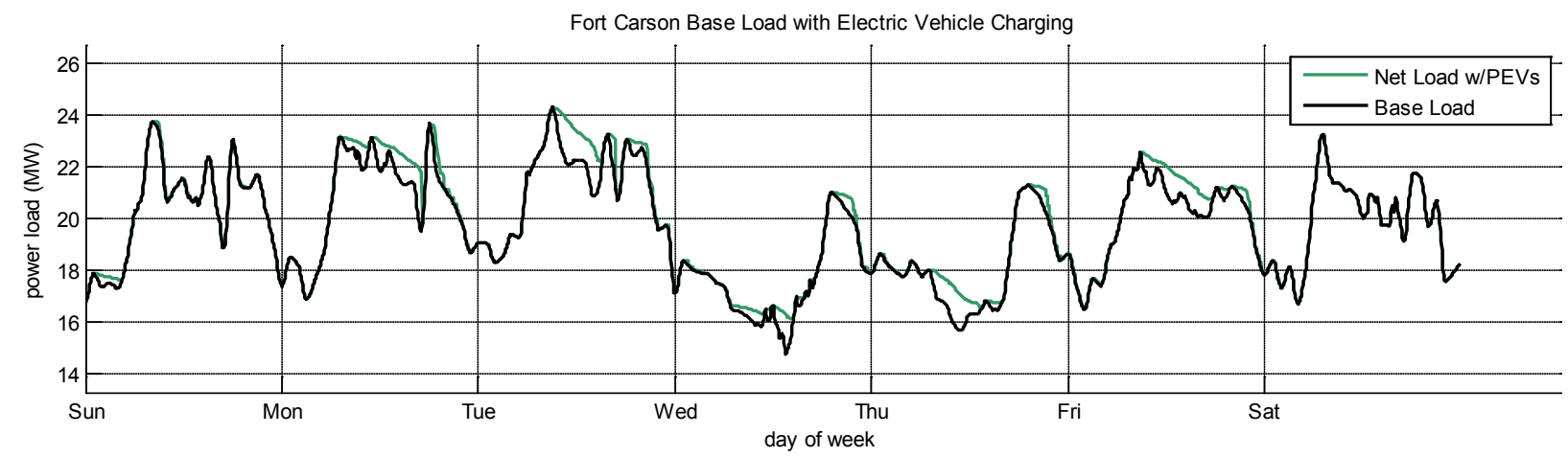

Figure A-13. During normal operations, both commuters and motor pool charging smoothes the required ramp rates for conventional generation

Although the benefits to the grid are relatively small, the vehicles received adequate charging without exceeding peak demand and at times even reduced peaks when solar power was available. Commuters left the base in these simulations with $60-100 \%$ of their capacity while providing a grid smoothing service; fleet trucks were $100 \%$ recharged before each day's route. Figure A-14 shows the remaining range left in the vehicles' batteries at any given time relative to a usable capacity ( $\sim 80 \%$ of total). Each line represents a unique vehicle. Commuter vehicles are charged during the day while motor pool vehicles are charged at night, though neither uses more than $50 \%$ of their range capability (because of the selection process described earlier in a section headed "Consumer Adoption of Electric Vehicles." 

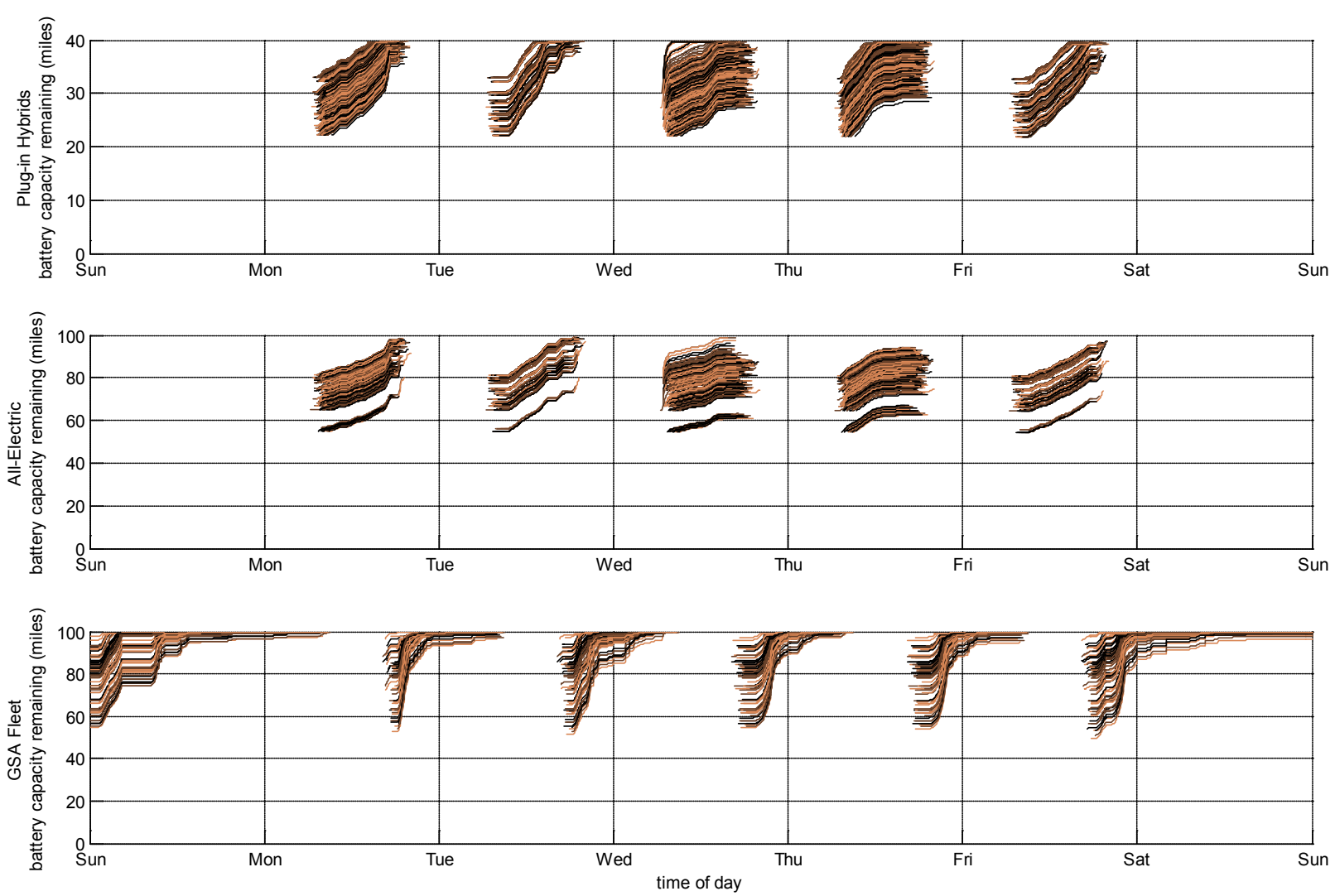

Figure A-14. Charging at ideal times supplies plenty of range for return commutes

On the other side of the meter, the fluctuations in power demand were smoothed when energy was available. When large amounts of solar energy became available (which frequently occurs as the sun emerges from cloud cover), PEVs absorbed the additional unexpected energy at a moment's notice (see Figure A-15). In practice, this compensating reaction would allow additional time to efficiently ramp down large generators without causing dangerous swings in voltage or frequency on the grid. The peaking plants that provided PEV charge energy in these simulations - natural gas turbines - typically produce cleaner power than coal, especially while functioning efficiently without severe changes to their power levels. 

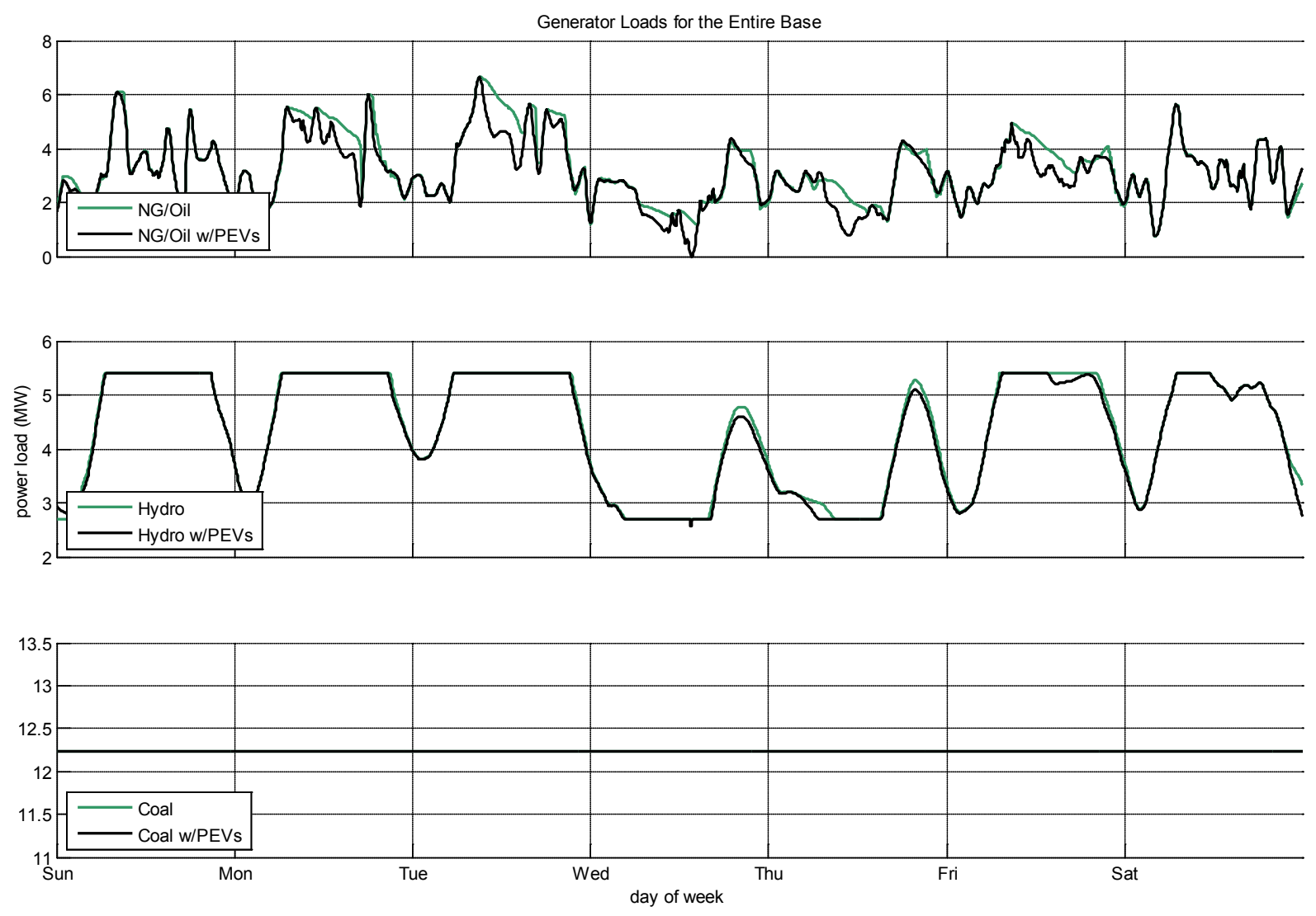

Figure A-15. Controlled charging helps to slow the drop-offs in demand during normal operations

Integrating vehicle charging made the net generator profile slightly more predictable (Figure A-16). 


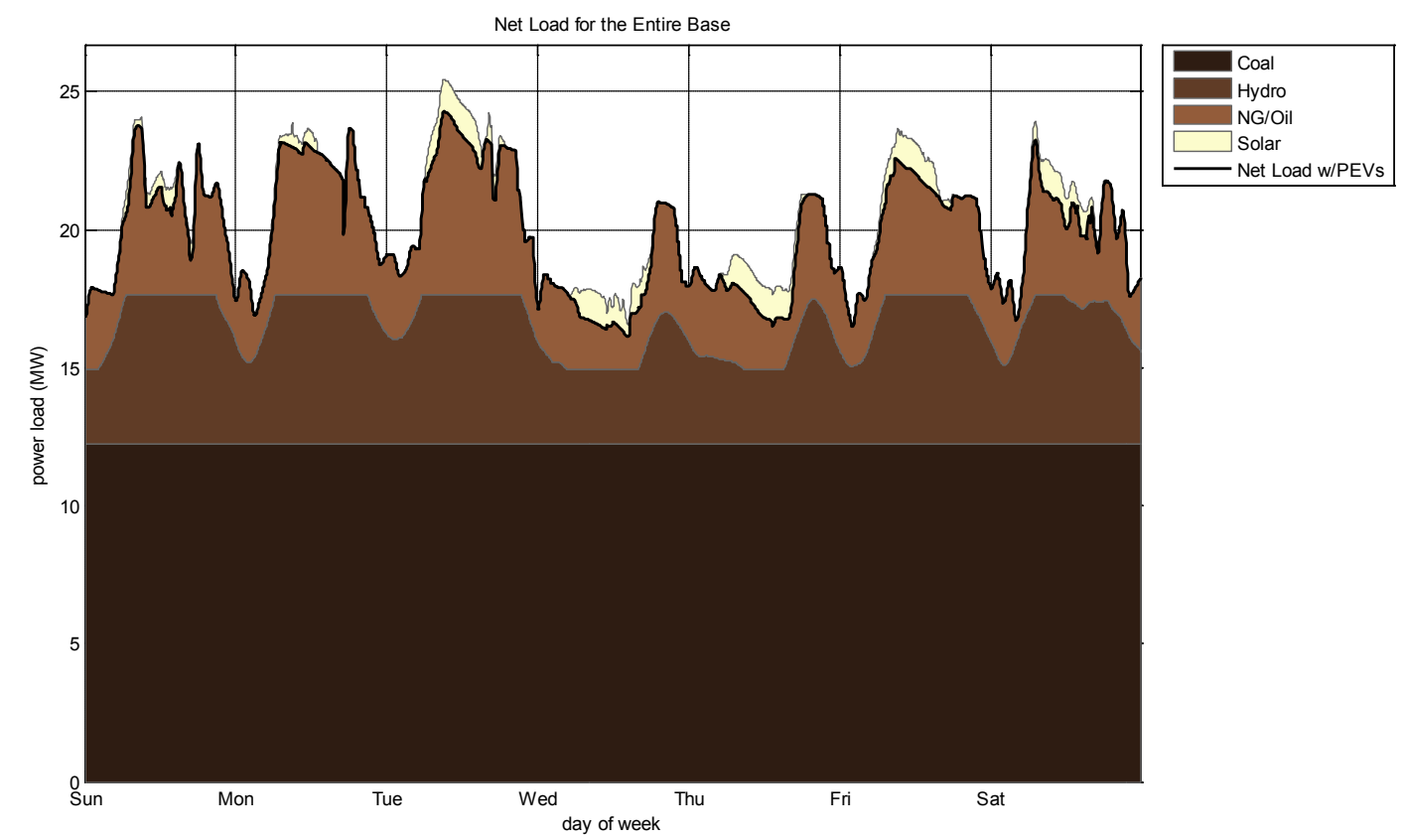

Figure A-16. Charging smoothes the aggregated load profile during normal operations

The results in Figure A-17 show that during emergency operations, properly managed charging deferred the vehicle power requirement to times when the demand is lower or when excess renewable energy was available. Each evening a large portion of the load reduction was absorbed by charging the motor pool electric trucks. Unfortunately, in this scenario, the $50 \%$ of vehicles that remain parked became relatively useless once completely charged. The benefits after these times were relatively diminished in the simulation.

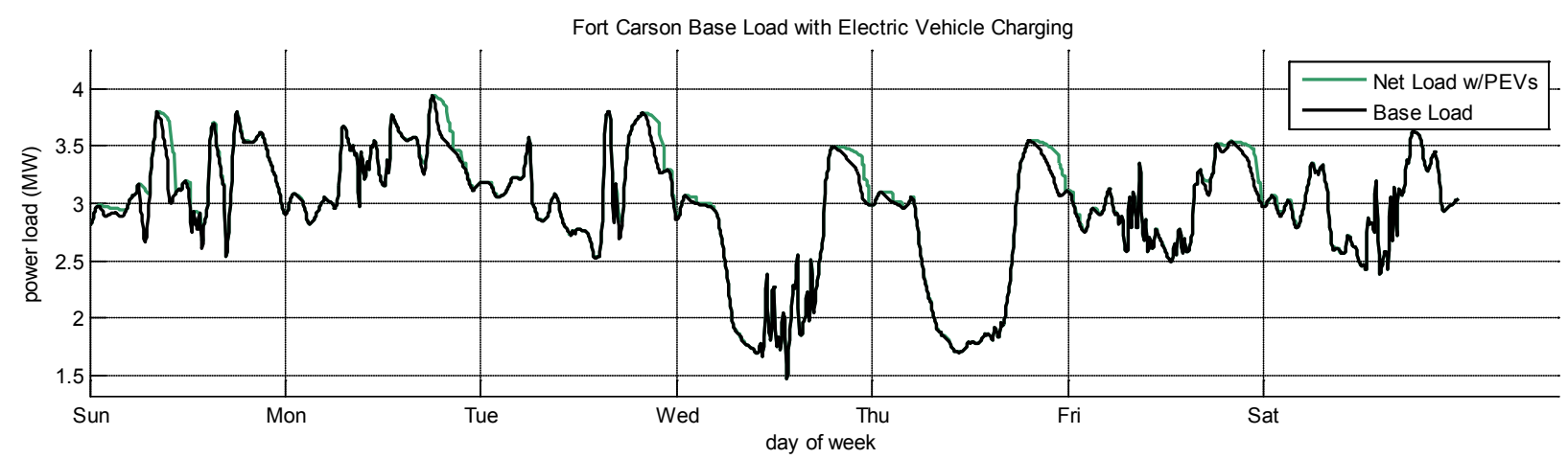

Figure A-17. Charge management can help buffer steep power fluctuations during emergency operations

Even with these charging restrictions, the Fort Carson microgrid could still provide enough energy for these vehicles each day without creating a new peak in demand. Figure A-18 shows the range capability for each electric truck. Each line represents a single truck's charge profile (or multiple trucks with identical charge profiles) while parked. 


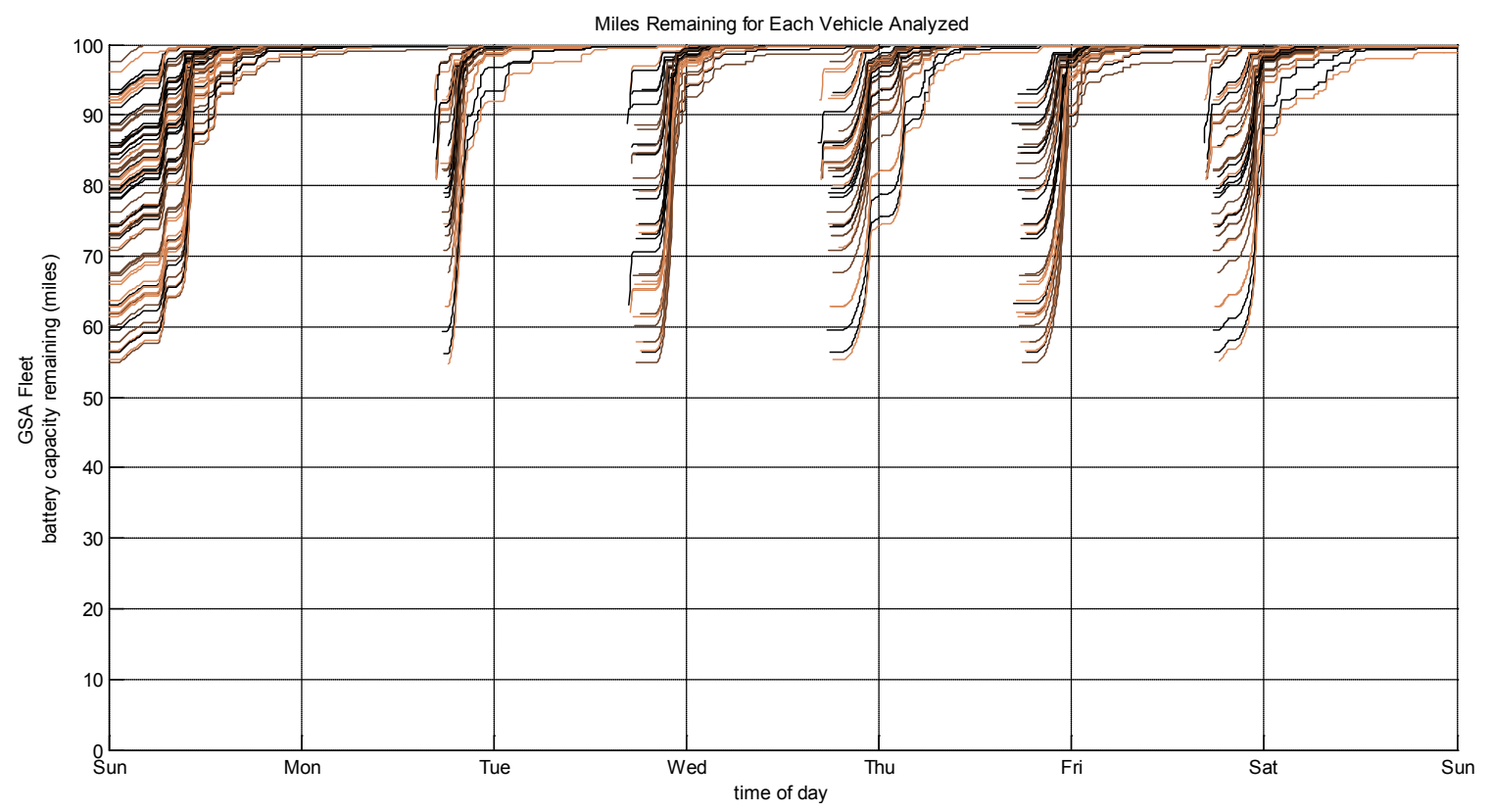

Figure A-18. Charging at ideal times supplies full range for all electric trucks during emergency operations

In fact, diesel fuel could be used more efficiently in on-site transportation by running generators that charge electric trucks during emergency conditions rather than by fueling diesel-powered trucks. Large generators run at roughly $35 \%$ efficiency and charge the vehicles at about $95 \%$ efficiency. Electric power trains in these vehicles operate at an average of about $80-85 \%$ efficiency, totaling roughly $27 \%$ pump-to-wheels efficiency while the average diesel truck runs at closer to $20 \%$ efficiency on average. Fort Carson's fleet can drive nearly $35 \%$ further with each gallon of fuel in electric vehicles and still support the microgrid.

This scenario affected generators significantly less than during normal operations. The change in operating profiles of the top most affected generators (in Figure A-19) show that the fleet alone adds relatively minimal loads and is unable to significantly level any major fluctuations. 

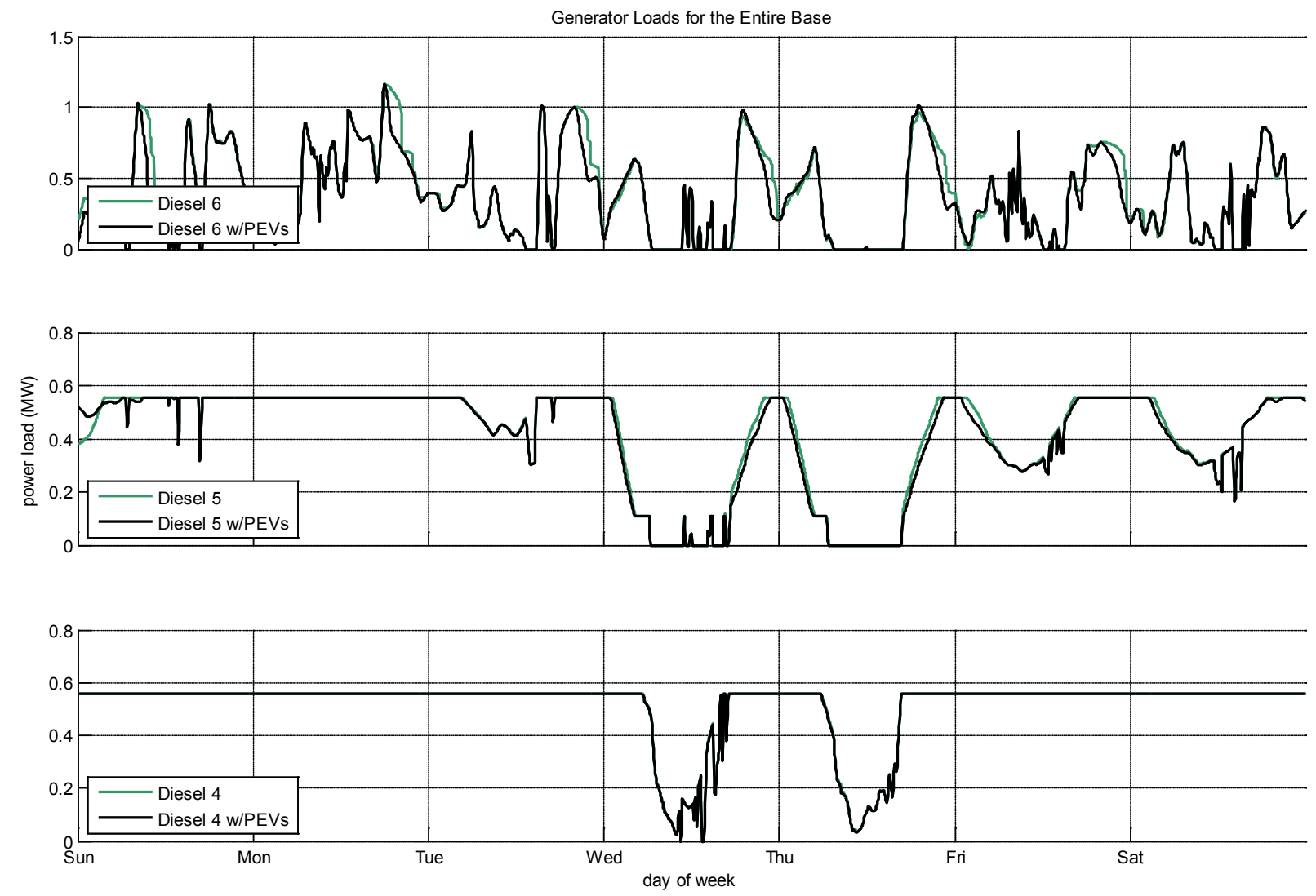

Figure A-19. Generators receive little benefit from an electric truck fleet during emergency operations

\section{Scenario 3: Vehicle Charging and Discharging (with management)}

The ability to discharge PEVs effectively doubles the range of power with which a grid operator can regulate the systems power budget. Additionally, the storage capacity of the PEVs connected to the grid could be used in load shifting and long duration load leveling.

Compared with the model results during charge management, the resulting net load profile with vehicle discharge capability was significantly smoother. Any sharp changes in load occurred primarily during times that vehicles left the charging station (to go home or on a route) as Figure A-20 shows. Those times coincided with large changes in the assumed demand loads. 


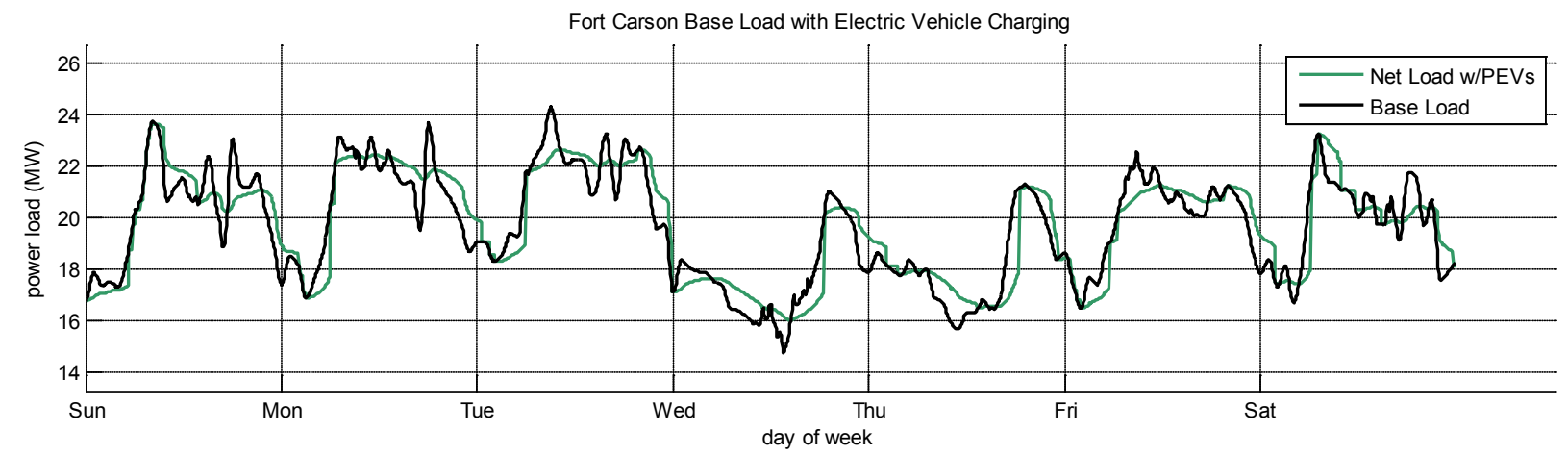

Figure A-20. V2G enabled load optimization and peak shaving during normal grid operations

This additional flexibility provided an opportunity to utilize generation resources in an optimal combination based on price, emissions, or other metrics. The actual source providing generation for PEV charging was selected for this simulation in the order in which it was deployed (base load, then peaking plants, then renewables). Figure A-21 depicts vehicle charging as positive power; discharging is negative. The different colored areas beneath the total load shift curve indicate the source of power generation or offset resulting from this scenario.

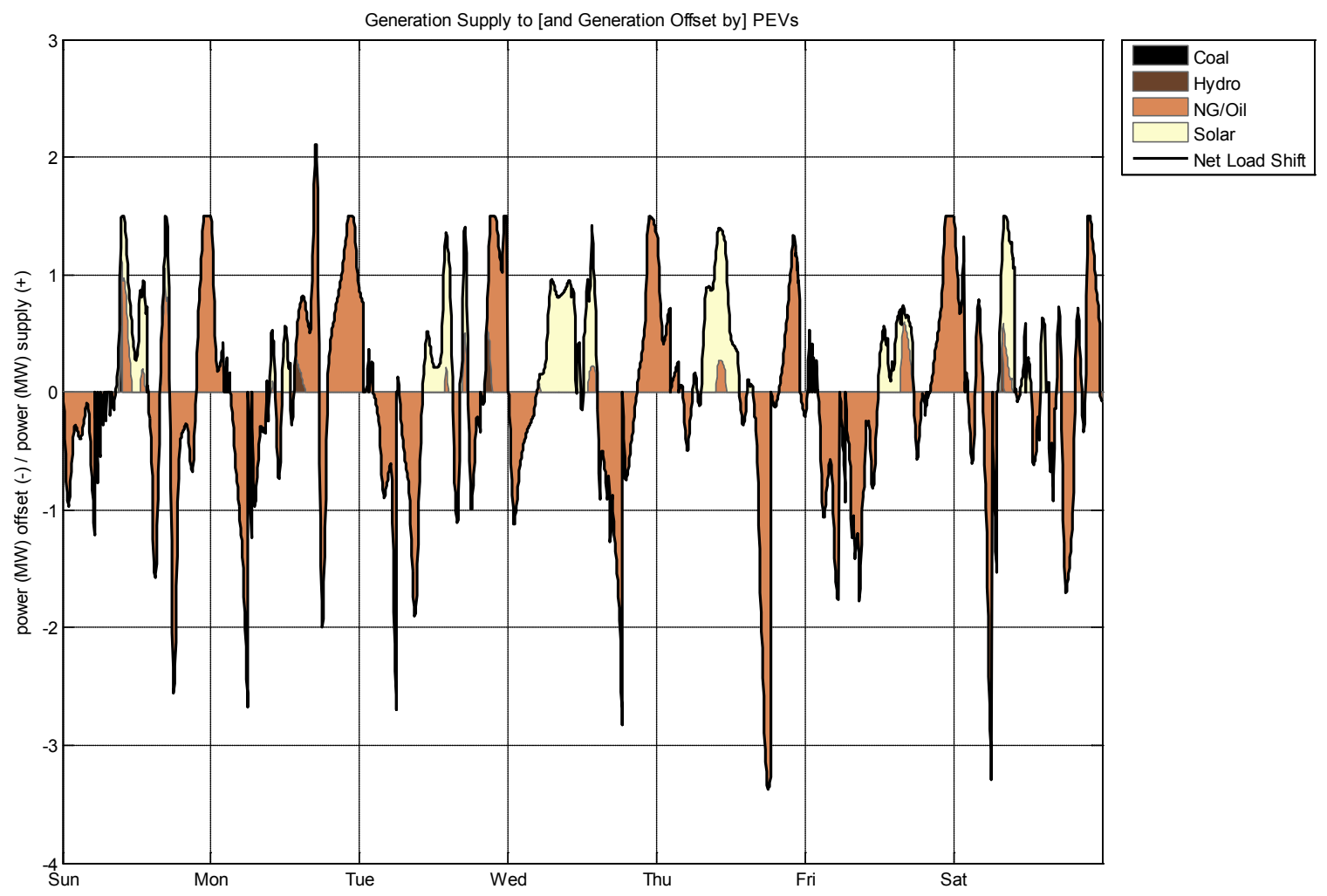

Figure A-21. Charging utilizes primarily solar power while V2G offsets fossil fuels 
Providing power back to the grid, the multiple commuter PEVs still left each day of the simulation with plenty of range to return home. The motor pool vehicles, due to their high power capabilities (Level III) and small quantities, exhibited wide capacity swings. Results in Figure A22 demonstrate the usefulness of each.
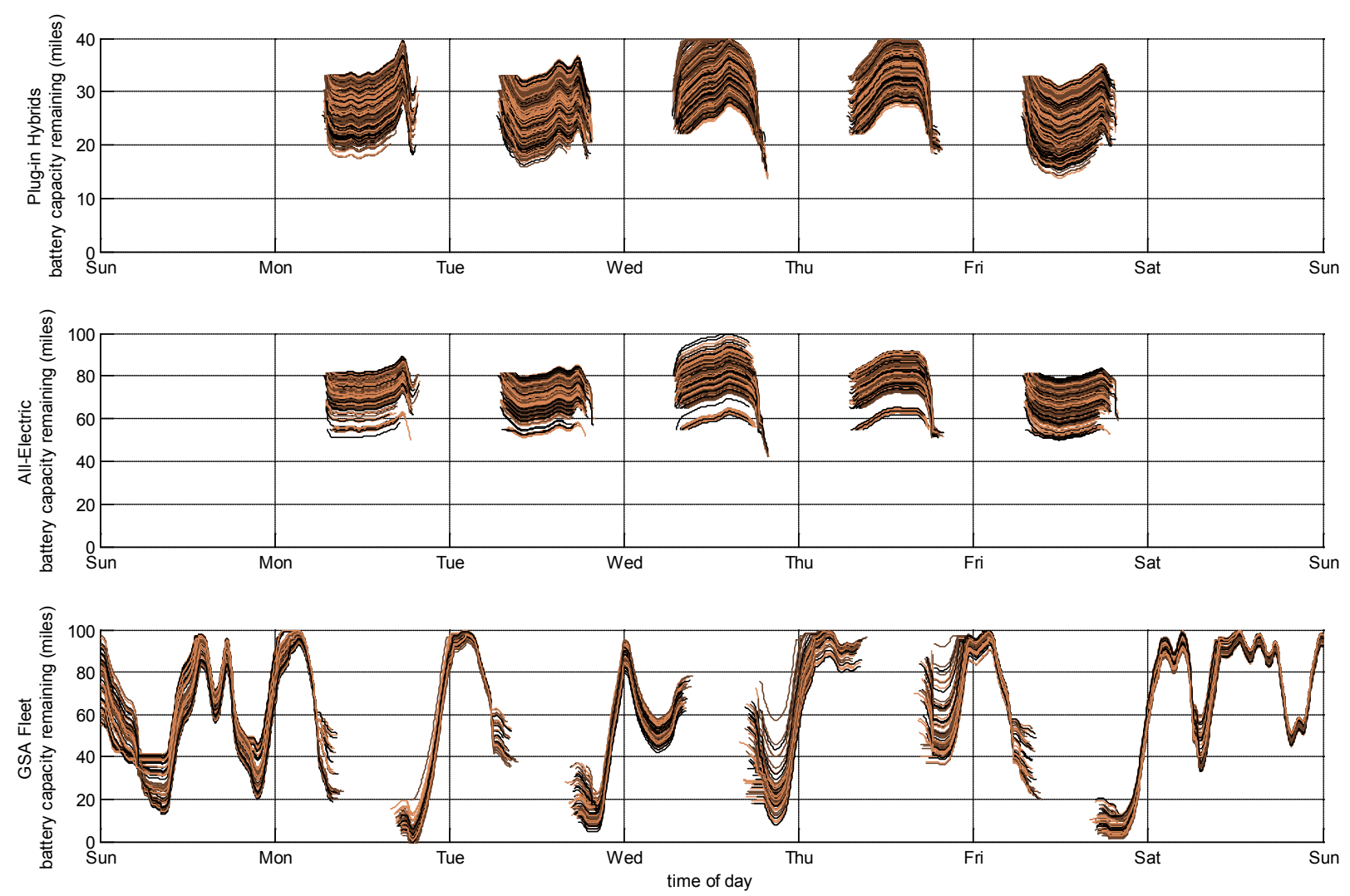

Figure A-22. With V2G each commuter exchanges relatively little energy while fleet vehicles manage nighttime and weekend loads

The final generator loads showed a delay in hydro power demands (giving additional warning for changes to their operating points) and a much smoother peaker plant profile. As shown in Figure A-23, the fleet shaved the highest peak, on Tuesday, by nearly $25 \%$. 

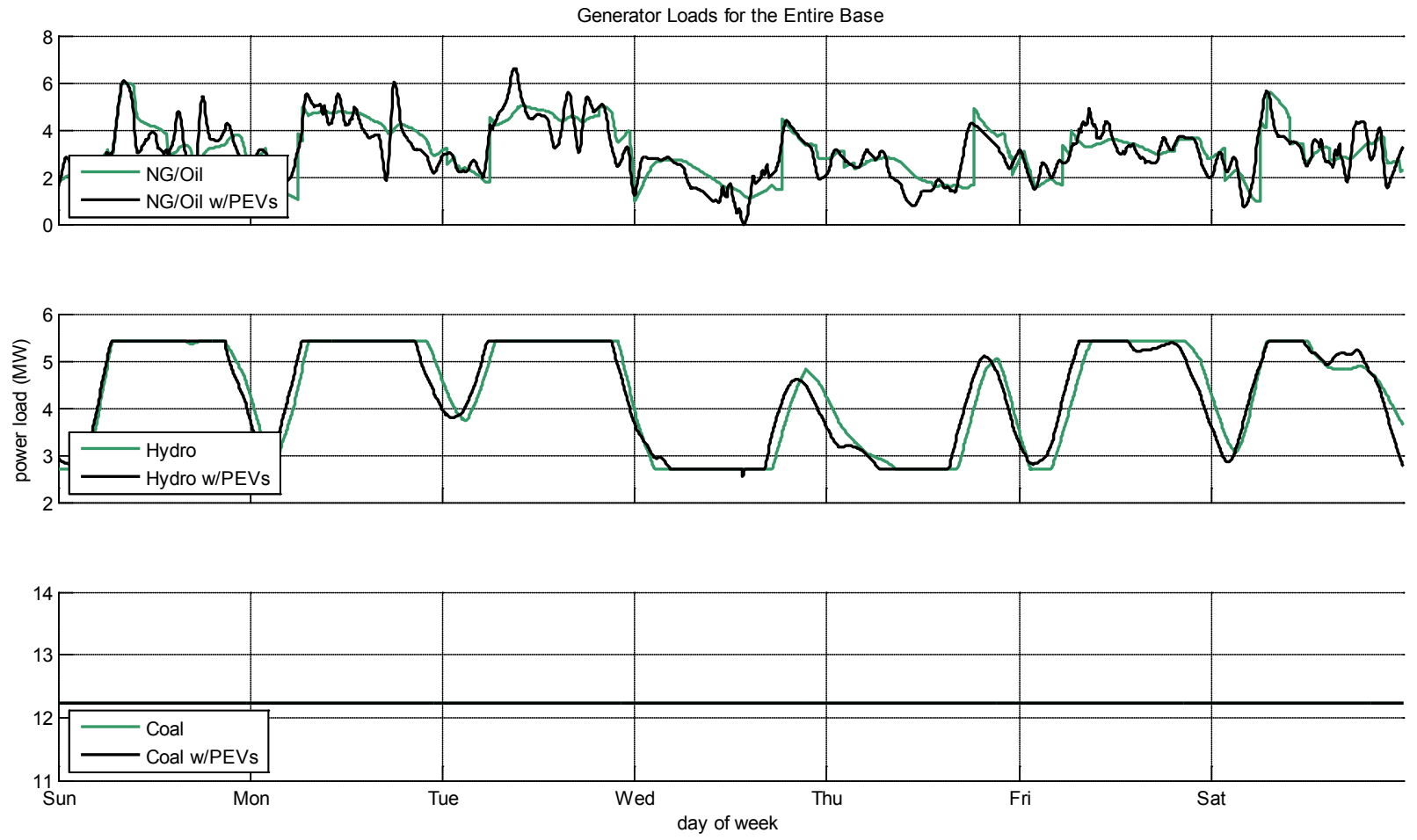

Figure A-23. V2G shaved peaks and fills valleys in the generator load profiles during normal operations

By integrating PEV energy storage, the normal Fort Carson demand profile, originally a spiky, unpredictable mess, ended up with almost two distinct power setting, quite predictable. Unfortunately, each day's resulting load contained large step changes from vehicles leaving and entering the grid (see Figure A-24). This pattern must be managed with alternative scheduling, or community energy storage devices. 

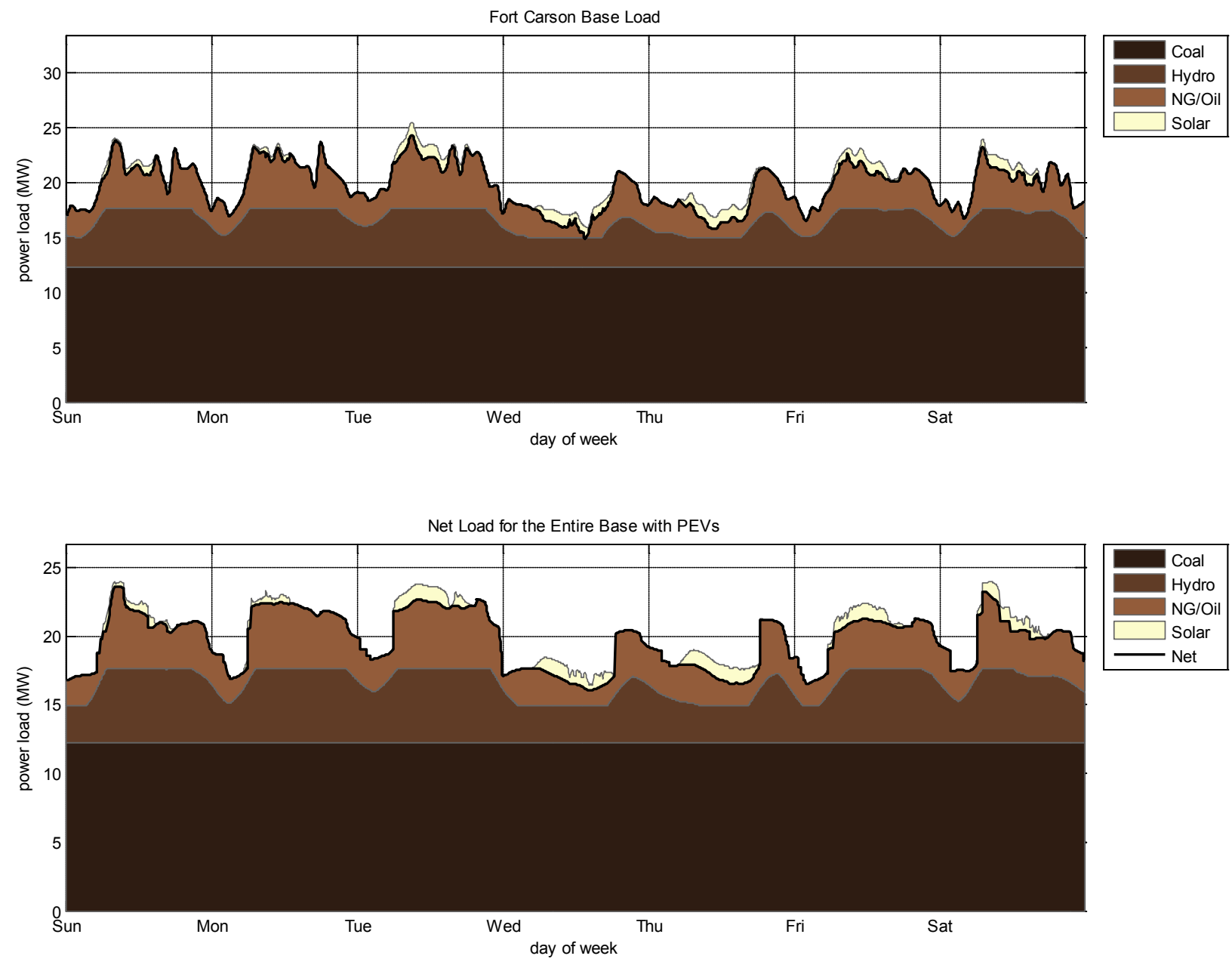

Figure A-24. Comparison of generation with and without PEVs exhibits their effect and potential benefits

During emergency operations, even a small fleet of electric trucks can help prevent some extreme load swings and better utilize the solar energy on-base. Mid-day loads during Wednesday and Thursday presented the highest concern, as they dropped significantly when demand was usually the highest. Additional solar power exacerbated the problem. As stated earlier, these profiles likely did not closely reflect actual loads on base. Figure A-25 shows the results of the exercise. 


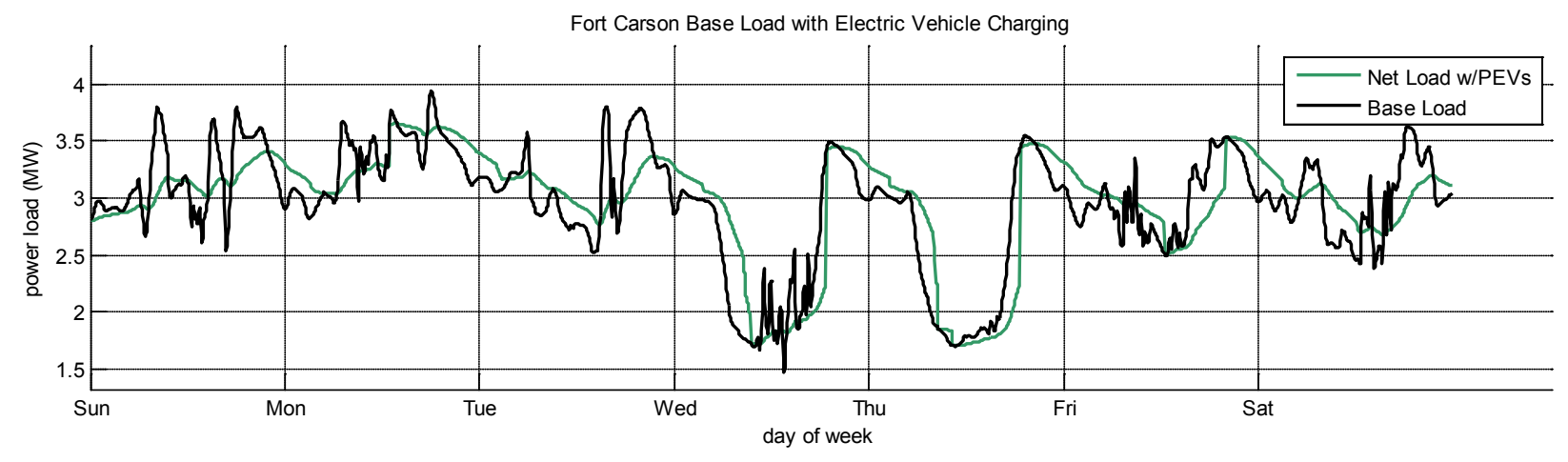

Figure A-25. Microgrid management of electric fleet truck V2G helps stabilize unpredictability of load demands and renewables supply

The supply to PEVs in Figure A-26 came primarily from solar power, enabling either clean transport, renewable load shifting, or both. Conversely, the power displaced by PEVs came primarily from the first three diesel generators.

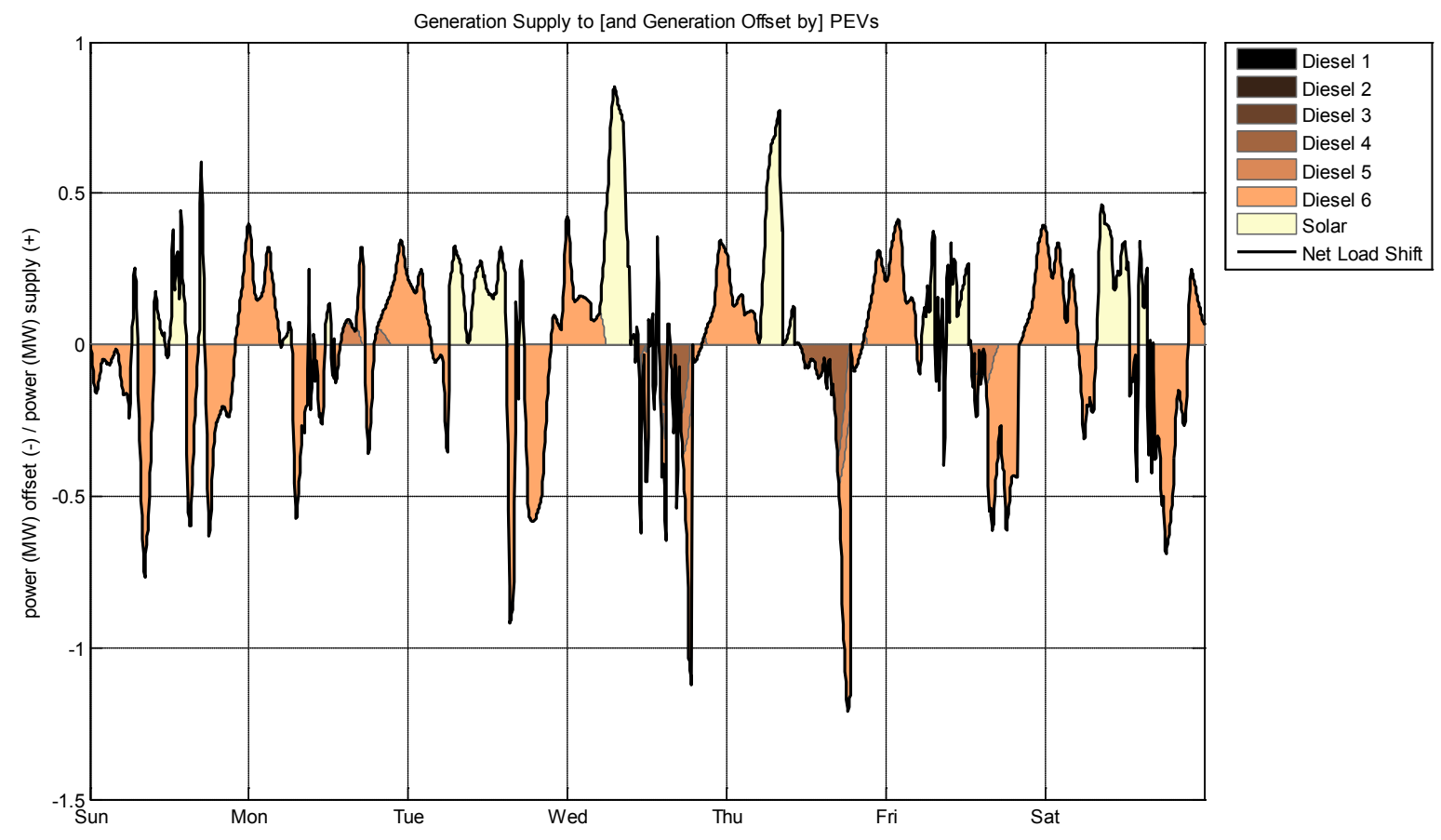

Figure A-26. Electric vehicles can help maintain emergency generators at optimal operating conditions

These grid management services require significant use of the fleet truck batteries, but the diurnal fluctuation in loads only draws approximately the equivalent of one cycle per day on each (see Figure A-27). 
Figure A-27 exhibits the even wider, more sporadic variations in state of charge that the motor pool experienced in these simulations.

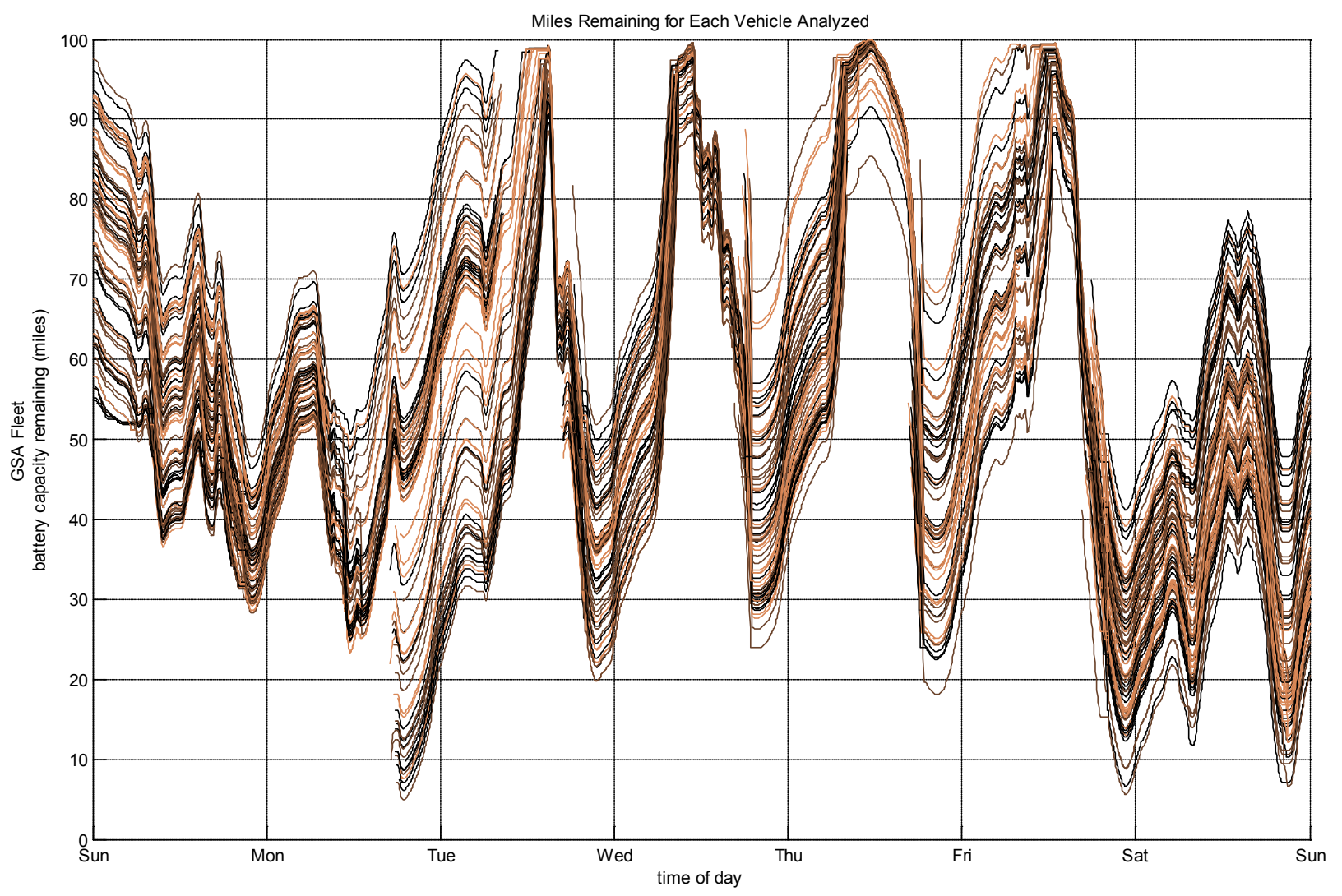

Figure A-27. Battery state of charge fluctuations during emergency V2G cycle roughly once per day

With relatively continuous storage assets, the microgrid in this simulation had large buffers which helped to delay and drastic changes. Again the top three generators handled the majority of load fluctuations; Figure A-28 shows their reactions. 

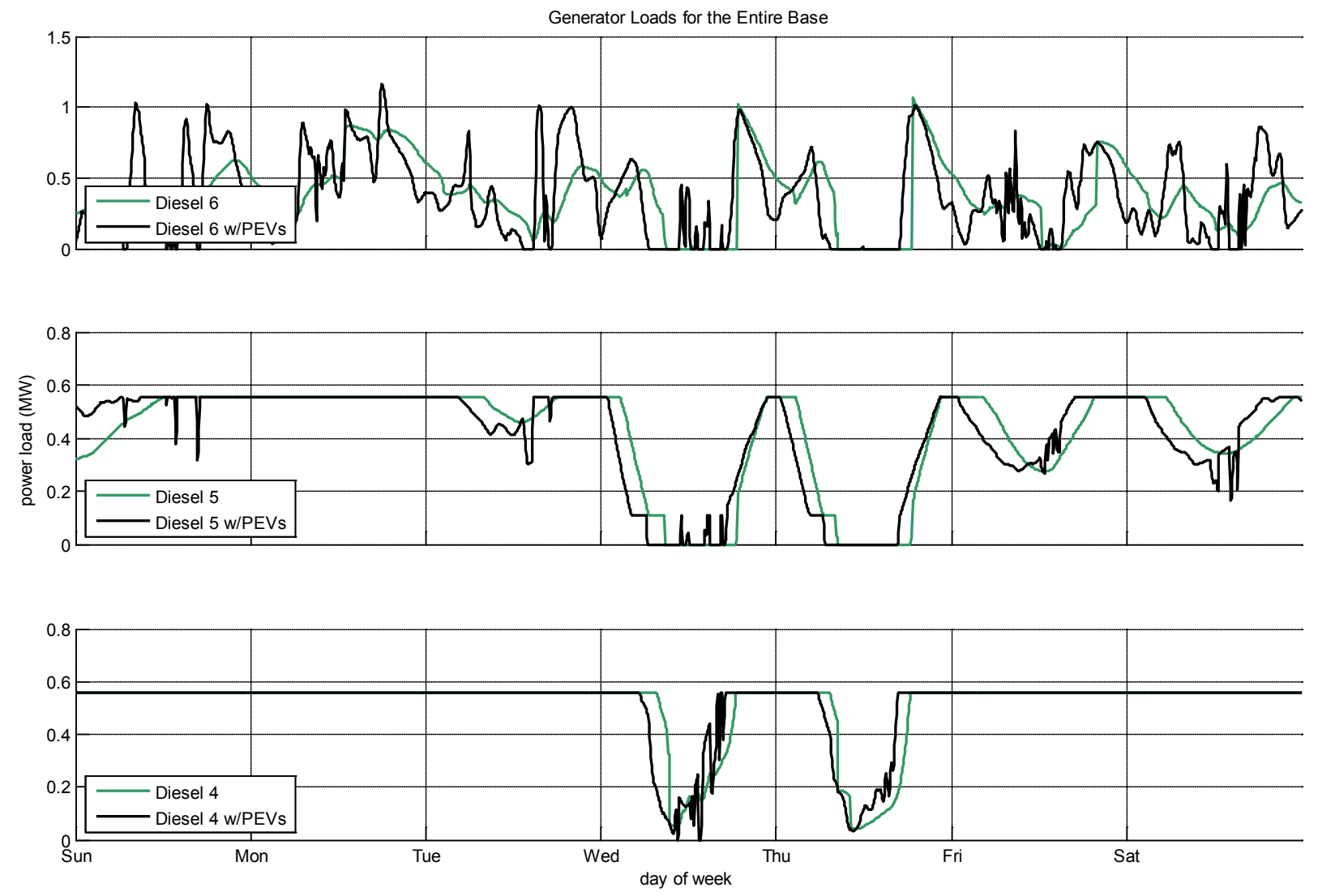

Figure A-28. V2G extended delay time and reduced overall ramping of generators during emergency operations

The net effects of these 75 fleet vehicles charging and discharging were easily recognizable when compared with a microgrid lacking any vehicle support (see Figure A-29). 

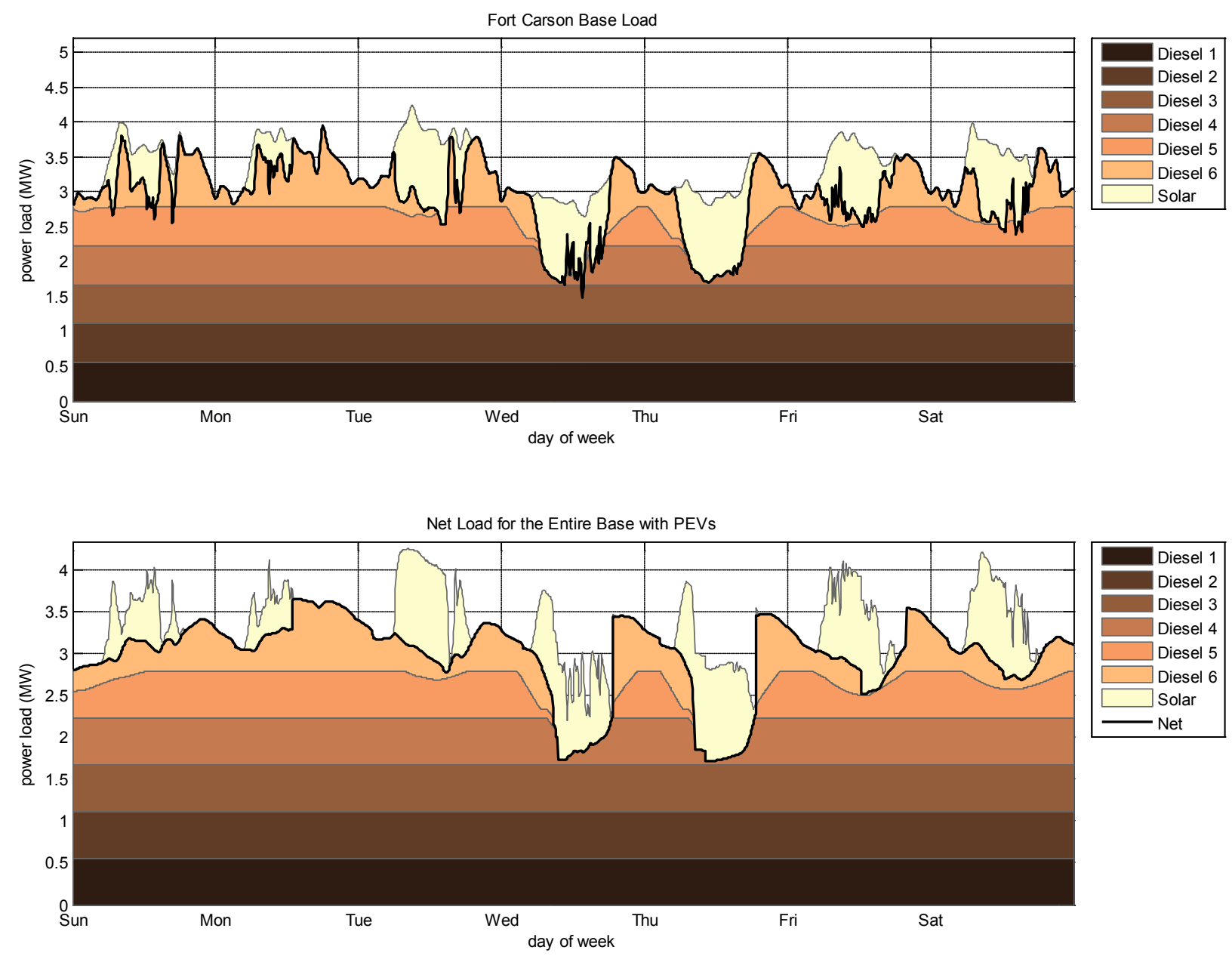

Figure A-29. Even a small fleet of motor pool PEVs enabled gradual ramping of loads during emergency operations when compared with the baseline scenario

\section{Demonstrating EVGI at Fort Carson}

In the future, Fort Carson is expected to become one of several focal points for a Joint Commands Technology Development (JCTD) project referred to as SPIDERS, with PACOM and USNORTHCOM orchestrating multi-force collaboration to expand deployment of secure microgrid technology. Creating technology with an acceptable readiness level is critical in support of the JCTD. One critical technology deployment will be vehicle-to-grid (V2G) technology providing stability management of microgrids with large scale renewables. The power flow management technology, the communications infrastructure, and systems operation scenarios are yet to be defined. The work outlined in the sections that follow, if conducted during FY 2011 would create the knowledge necessary to fill the gap between technology development and deployment in support of the V2G technology needed for SPIDERS.

NREL internally funded work during the past two years and in the coming year that provides a foundation of research on vehicle-to-grid technologies, testing, and operations. A pilot Renewable Charging Station and a demonstration PHEV with V2G has been created. V2Gcapable vehicles have been tested to existing grid integration standards. A bi-directional Level III 
fast-charge system is planned for installation at NREL in FY 2011 Q1. This system will offer a facility for understanding the attributes and grid impacts of fast-charge systems.

Figure A-30 depicts the combination of PV providing shade for vehicles and energy to the microgrid along with vehicle energy management portals. The portals show a combination of Level III (20-250KW) and Level II (0-20kW) access points (as indicated). Systems optimization analysis is needed to understand the scalability to satisfy several vehicles to thousands of vehicles. We recommend further investigation to determine the attributes of this system relative to available electricity grid distribution systems and the microgrid operations.

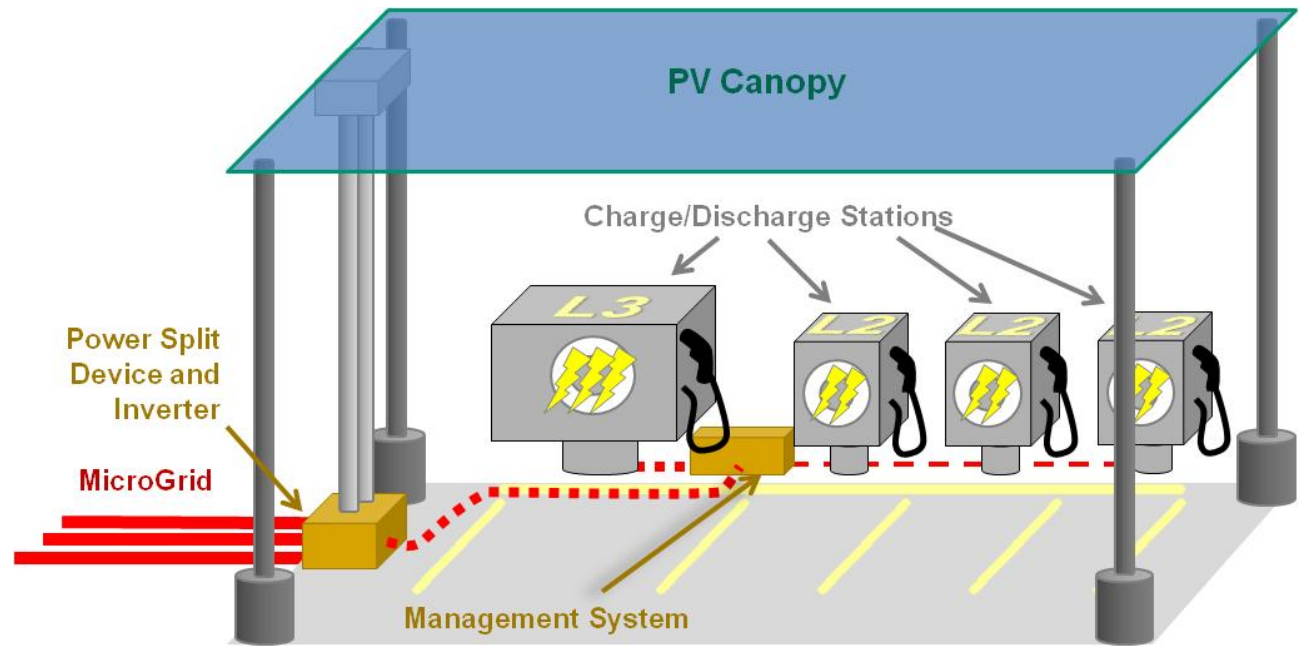

Figure A-30. Scalable renewable PEV energy management component for microgrids (Credit: Mike Simpson, NREL)

With the added benefits of providing premium covered parking, these systems will add to the onsite renewable energy generation without occupying rooftops. NREL's NZEI team identified several locations along the microgrid corridor in which these carport-charging systems may be particularly valuable (see Figure A-31). 


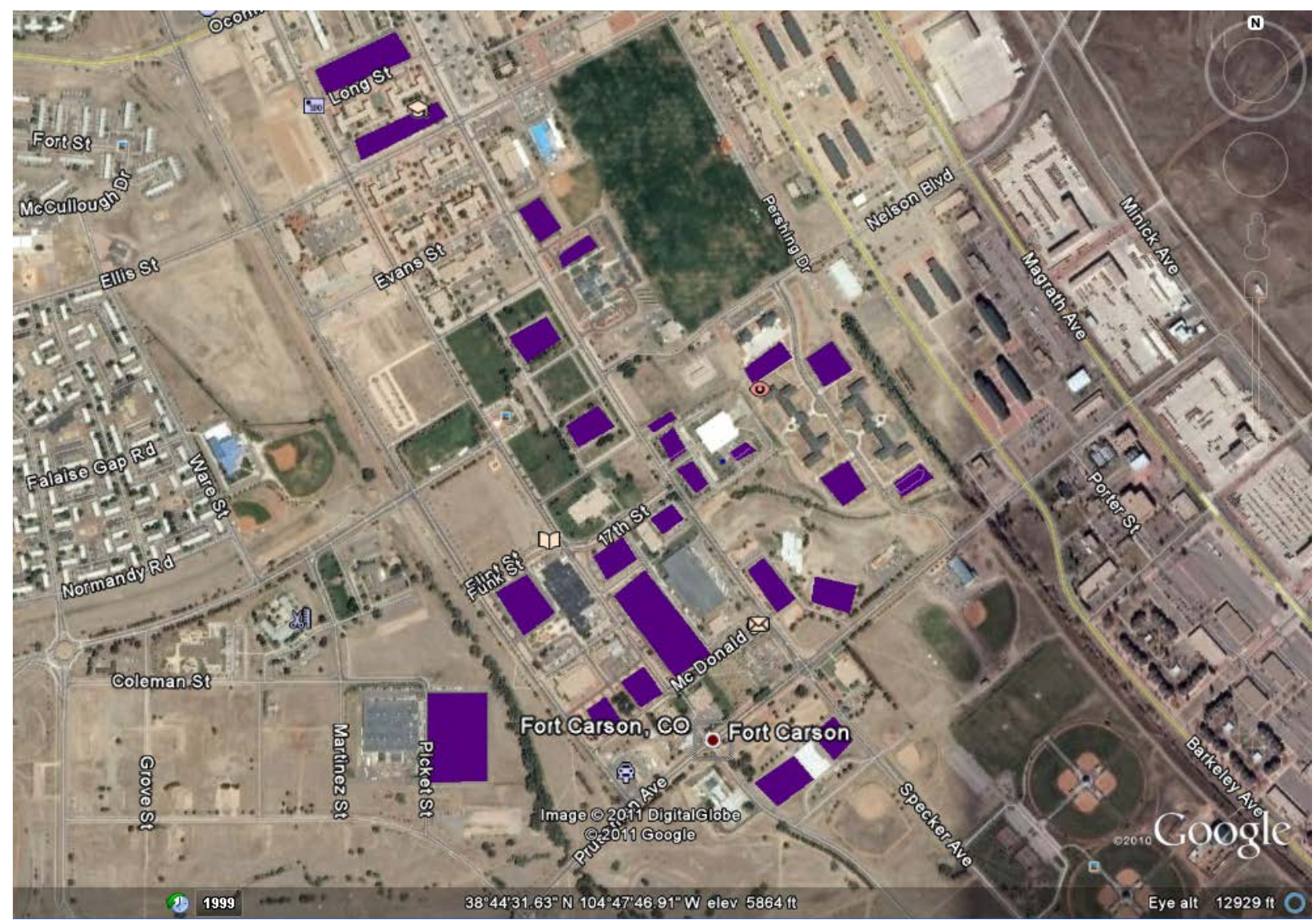

Figure A-31. Possible solar carport locations

\section{Expected Issues}

While this model represents relatively high-fidelity estimations of potential electric vehicle grid interactions, we can solidify the details required for implementation planning only through demonstrations as just described. We will have to address several remaining deployment considerations in this next phase. Issues include:

- Capital and installation costs of EVSE. Many EVSE manufacturers have published MSRPs for their various products, but great uncertainties in the costs of permitting and installation contracts remain. These factors will vary significantly depending on the municipality and contractor.

- Circuit supply upgrade requirements. Building codes are quite different between locations. Electrical infrastructure "behind the wall" of EVSE locations may require as little as no development, or as much as total rework, depending on the age and location of a facility and power availability (phases, voltages, amperage).

- Dedicated parking spots. Consumer studies indicate that PEV owners/operators will want to charge their vehicles often ${ }^{37}$ and EVSE may be in high demand at Fort

\footnotetext{
${ }^{37}$ Neenan, B.; Cromie, R.; Wheat, T. "Characterizing Consumers' Interest in and Infrastructure Expectations for Electric Vehicles: Research Design and Survey Result.” EPRI. May 2010.
} 
Carson. The need for EVSE may or may not align with the desire for dedicated parking and the needs of the microgrid.

- Electricity accounting differences between civilian and military vehicles. If we view commuter vehicles as a resource to the base's grid operations, they must be provided with electricity. The rates at which charges are made available to civilian owners of these vehicles will be at the administration's discretion and will likely be different than the rates for GSA vehicles. Additionally, a non-utility is restricted from reselling electricity, but can recoup expenses by establishing fees for parking or time at the charger.

- Fleet vehicle turnover rates with respect to payback period of grid services. GSA vehicles are typically replaced within a few years (and only heavy duty vehicles are kept for longer than 10 years), ${ }^{38}$ but some of the first waves of PEVs will have incremental costs that require longer payback periods based on fuel savings alone. Fortunately, battery price forecasts indicate incremental costs will quickly drop, although the business case will depend on alternative functions (such as grid integration) early on.

- Feasibility and safety of bi-directional power flow in practice. Today, power is predominantly delivered to the grid by utility-sanctioned generators and distributed renewables (residential wind and solar), but requires sophisticated synchronization via highly refined power electronics. NREL tests indicate that bi-directional power exchange from vehicles (V2G) is feasible, but wide-scale implementation has yet to be demonstrated.

- Secure data collection, handling, and communication. PEV grid integration can boost military security by enhancing the reliability of their grid. However, large amount of information will be exchanged in the "smart" microgrid, which enables these abilities and must be transmitted, processed, and stored securely. Precedents have been established, but with new equipment (or new uses of established equipment) comes new risk.

- Relocation of staff (and their vehicles) with limited fixed EVSE. NREL has found that, due to the frequency with which offices are relocated within Fort Carson, dedicated parking is not worth a significant investment. EVSE is not typically relocated once installed, so it is important to properly plan and locate charging stations from the beginning of deployment.

\section{Conclusions}

PEVs present opportunities to reduce fuel costs and utility bills, while meeting alternative fuel requirements. Their dual roles in efficient transportation and utility assets bolster a reduction in petroleum consumption and an increase in local fuel sources, especially renewable energy.

NREL found that Fort Carson can effectively use these vehicles in many, if not all, vehicle charge control scenarios to achieve internal and Federal goals, resulting in a more robust transportation and electricity system. However, these results are highly dependent on the

\footnotetext{
${ }^{38}$ GSA, “Important Fleet Publications.” www.gsa.gov/portal/content/104230. Accessed August 3, 2010.
} 
assumptions, of which the demand load is the most questionable. Any further progress will require proper data collection from utility meters on base.

Most notably, the PEVs exhibited the largest potential for enhanced grid efficiency when utilized in proper coordination, and/or with bi-directional charge capability. It was found that 75 motor pool vehicles did not provide enough benefit for justified investment in electric trucks in a controlled-charge-only configuration on the microgrid, but V2G changed the story significantly by effectively supplying storage with twice the power and energy ranges.

True, in both normal and emergency situations, the relatively continuous storage assets assisted the microgrid in this simulation, providing large buffers and delaying drastic changes. With dedicated planning and software development, this reaction could help bolster the reliability of controls in the microgrid system. Still, arrival and departure times of vehicles coincided with large changes in the assumed demand loads. If the actual base loads turn out in reality to be similar, it may become necessary to institute staggered schedules for additional grid stability.

Finally, the small amount of control applied to charging dynamics in these simulations limits the minimum battery state-of-charge to each vehicle's required commute/route energy, plus a $20 \%$ margin while providing this service. Generally, simulations did not reach this limit, but future control algorithms may utilize advanced regulation schemes. The wide swings in battery capacity reflect equally great benefits to the grid (representing power and energy offsets in generation), but cycling these batteries may have degraded them faster and replacement costs could eventually overshadow any energy savings.

Regardless, this simulation study offers valuable insight to potential design spaces for a base with PEVs. The assumptions must now be vetted through an on-site, physical demonstration. NREL recommends that Fort Carson implement a program to demonstrate each of these modes of operation throughout 2011, as Smith Electric trucks and a microgrid infrastructure become available. 


\section{EERE Information Center}

1-877-EERE-INFO (1-877-337-3463)

www.eere.energy.gov/informationcenter

\section{waster. ENERGY \\ Energy Efficiency \& Renewable Energy}

DOE/GO-10211-3329 - October 2011

Printed with a renewable-source ink on paper containing at least $50 \%$ wastepaper, including $10 \%$ post-consumer waste. 